\title{
A Preliminary Assessment of the Satellite Power System (SPS) and Six Other Energy Technologies
}

T. Wolsko, C. Brown, R. Cirillo, J. Gasper,

L. Habegger, K. Hub, E. Levine, D. Newsom,

M. Samsa, E. Tanzman, J. VanKuiken, and R. Whitfield 


\section{DISCLAIMER}

This report was prepared as an account of work sponsored by an agency of the United States Government. Neither the United States Government nor any agency Thereof, nor any of their employees, makes any warranty, express or implied, or assumes any legal liability or responsibility for the accuracy, completeness, or usefulness of any information, apparatus, product, or process disclosed, or represents that its use would not infringe privately owned rights. Reference herein to any specific commercial product, process, or service by trade name, trademark, manufacturer, or otherwise does not necessarily constitute or imply its endorsement, recommendation, or favoring by the United States Government or any agency thereof. The views and opinions of authors expressed herein do not necessarily state or reflect those of the United States Government or any agency thereof. 


\section{DISCLAIMER}

Portions of this document may be illegible in electronic image products. Images are produced from the best available original document. 
The facilities of Argonne National Laboratory are owned by the United States Government. Under the terms of a contract (W-31-109-Eng-38) among the U. S. Department of Energy, Argonne Universities Association and The University of Chicago, the University employs the staff and operates the Laboratory in accordance with policies and programs formulated, approved and reviewed by the Association.

\section{MEMBERS OF ARGONNE UNIVERSITIES ASSOCIATION}

The University of Arizona

Carnegie-Mellon University

Case Western Reserve University

The University of Chicago

University of Cincinnati

Illinois Institute of Technology

University of Illinois

Indiana University

The University of Iowa

Iowa State University
The University of Kansas

Kansas State University

Loyola University of Chicago

Marquette University

The University of Michigan

Michigan State University

University of Minnesota

University of Missouri

Northwestern University

University of Notre Dame
The Ohio State University

Ohio University

The Pennsylvania State University

Purdue University

Saint Louis University

Southern Illinois University

The University of Texas at Austin

Washington University

Wayne State University

The University of Wisconsin-Madison

NOTICE

This report was prepared as an account of work sponsored by an agency of the United States Government. Neither the United States Government or any agency thereof, nor any of their employees, make any warranty, express or implied, or assume any legal liability or responsibility for the accuracy, completeness, or usefulness of any information, apparatus, product, or process disclosed, or represent that its use would not infringe privately owned rights. Reference herein to any specific commercial product, process, or service by trade name, mark, manufacturer, or otherwise, does not necessarily constitute or imply its endorsement, recommendation, or favoring by the United States Government or any agency thereof. The views and opinions of authors expressed herein do not necessarily state or reflect those of the United States Government or any agency thereof.

Printed in the United States of America

Available from

National Technical Information Service

U. S. Department of Commerce

5285 Port Royal Road

Springfield, VA 22161

NTIS price codes

Printed copy: A09

Microfiche copy: A01 
Distribution Category:

Economic, Social, and

Environmental Aspects

of Solar Energy (UC-58b)

ANL $/ \mathrm{AA}-20$

ARGONNE NATIONAL LABORATORY

9700 South Cass Avenue

Argonne, Illinois 60439

\begin{abstract}
A PRELIMINARY ASSESSMENT OF THE
SATELLITE POWER SYSTEM (SPS)

AND SIX OTHER ENERGY TECHNOLOGIES
\end{abstract}

by

T. Wolsko, C. Brown, R. Cirillo, J. Gasper, L. Habegger, K. Hub, E. Levine, D. Newsom, M. Samsa, E. Tánzman,

J. Vankuiken, and R. Whitfield

Energy and Environmental Systems Division

Integrated Assessments and Policy Evaluations Group

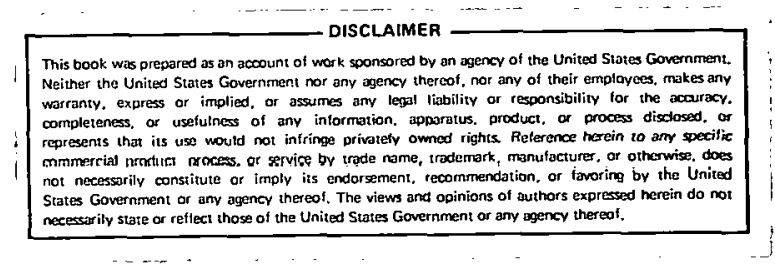

Apr i 1980

\author{
Sponsored by \\ U.S. DEPARTMENT OF ENERGY \\ Office of Energy Research \\ Satellite Power System Project Division
}


THIS PAGE

\section{WAS INTENTIONALLY LEFT BLANK}


FOREWORD

The objective of this assessment, sponsored by the DOE Satellite Power System (SPS) Project Division, is to develop, to the extent possible, information on the prospective viability of the SPS concept. It is intended that this assessment assist the decision maker in evaluating the significance of the SPS concept. To provide perspective, similar information is developed for a limited set of other electric power-producing technologies that could be deployed in the post-2000 period.

To accomplish this objective, pertinent information is displayed side-by-side for each of the alternate technologies, with all data normalized to unit bases such as dollars per megawatt or environmental residuals per megawatt. A later assessment will update and expand these side-by-side data and analyze the SPS role within various plausible future energy scenarios, to examine possible energy technology mixes, supply/demand cases, and the resultant environmental and resource issues and costs. Neither report will attempt to compare $R \& D$ and infrastructure cost requirements.

It must be stressed that it was not the objective of this assessment to make direct comparisons between the technologies that are possible alternatives to SPS (e.g., between coal and fission, or fission and fusion, etc.). The speculative nature of estimating the costs of emerging technologies into the next century, in itself, makes such comparisons difficult. All assumptions, uncertainties, and inconsistencies have been noted and documented. Within the limitations of the assumptions made and of the data employed, it is believed that the side-by-side comparison of SPS with the alternatives is useful in the decision process. 


\section{ACKNOWLEDGMENTS}

The authors are grateful to the following reviewers who contributed to this report through their constructive comments: M.R. Riches and F.A. Koomanoff, Department of Energy; R. Ayres, Carnegie-Mellon University; S. Cohen, TRW; and the members of the Comparative Assessment Review Committee: J.G. Asbury, Argonne National Laboratory; R.E. Bailey, Ohio State University; R.W. Bossert, New York State Consumer Protection. Board; K. Bossong, Citizens' Energy Project; G. Deloss, Environmental Policy Center; G.A. Kent, Glenn A. Kent Associates; B.D. LaMar, Argonne National Laboratory; A. Manne, Stanford University; T.J. Nagel, American Electric Power Service Corporation; and G. $\Lambda$. Tolley, University of Chicago. 


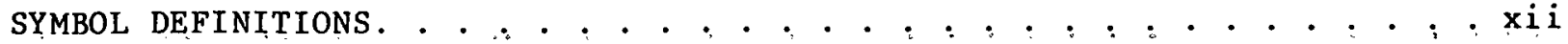

EXECUTIVE SUMMARY . . ...................... . . . . . . . . . . . . .

1 INTRODUCTION . . . . . . . . . .... . . . . . . . . . . . 1

1.1 BACKGROUND, . . . . . . . . . . . . . . . . . . : . . : ; : 1

1.2 OBJECTIVE AND APPROACH. . . . : ... : . : ...... 2

2 ASSESSMENT FRAMEWORK .......... : : . . . . . : . . : : 5

2.1 OVERVIEW. . . . . . . . . . . . . . . . . . . : . 5

2.2 COMPARATIVE ISSUES. . . . . . . . . . . . . : : . 5

2.3 ENERGY ALTERNATIVES SELECTION . . . . . . . . . . : : : : 7

2.4 ENERGY SYSTEM CHARACTERIZATION, : : : . ....... : : : 9

2.5 SIDE-BY-SIDE ANALYSIS OF ENERGY SYSTEMS . . . . . . . . . : 10

2.6 ALTERNATIVE FUTURES ANALYSIS AND
INTEGRATION/AGGREGATION TECHNIQUES . . . . . . . . . . . . . 10

3 CHARACTERIZATIONS OF THE SPS AND ALTERNATIVE TECHNOLOGIES. . . . $\therefore 11$

3.1 ALTERNATIVE TECHNOLOGY SELECTION. : . . . . . . . . . : : : 11

3.2 TECHNICAL DESCRIPTION OF ALTERNATIVE GENERATION SYSTEMS : : : : 15

3.2.1 Satellite Power System . : . . . . . . . . . . . . 16

3.2.2 Terrestrial Photovoltaic System. . . . . . . . . . 21

3.2.3 High-Sulfur Coal Power Plant.............. . 23

3.2.4 Coal-Gasification/Combined-Cycle Power Plant...... . 26

3.2 .5 Light Water Reactor Power Plant. . . . . . . . , 29

3.2.6 Liquid-Metal, Fast-Breeder Reactor : . . . . . . : 32

3.2 .7 Fusion .................... . : 37

3.3 COST CHARACTERIZATIONS. . . . . . . . . . . . . . . 39

4 ISSUE COMPARISONS. . . . . . . . . . . . . . . . . . . . 47

4.1 COST AND PERformAnCE. . . . . . . . . . . . . . . . 47

4.1.1 Issue Description and Analyt ic Approach. . . . . . . . . . 47

4.1.2 Individual Technology Comparisons. . . . . . . . , 48

4.1.3 Technology Integration into Electrical Supply Systems. . 58

4.1.4 Approach to Integration Analyses ........... 59

4.1.5 Cost and Performance Uncertainty ........... 67

4.1.6 Comparison of Terrestrial and Space Photovoltaic

Technologies ............... 74

4.1.7 Development Costs. . . . . . . . . . . . . . . 78

4.1 .8 observations . . . . . . . . . . . . . . 78

4.2 HeAlth AND SAfETY . . . . . . . . . . . . . . . 81

4.2.1 Introduction . . . . . . . . . . . . . . . 81

4.2.2 Issue Identificatinn, Severity, and Uncertainty . . . 82 
TABLE OF CONTENTS (Cont'd)

$\underline{\text { Page }}$

4.2.3 Issue Description and Comparison . . . . . . . . 85

4.2.4 Satellite Power System . . . . . . . . . 85

4.2.5 Light Water Reactors with Fuel Reprocessing. . . . . 87

4.2.6 Coal Gasification/Combined Cycle . . . . . . . . 87

4.2.7 Central Terrestrial Photovoltaic Systems . . . . . . 90

4.2.8 Fusion . . . . . . . . . . . . . . 92

4.2.9 Technology and Impact Category Comparison. . : . . . 92

4.2.10 Gaps in Information and Future Study . . . . . . . 98

4. 3 ENVIRONMENTAL WELFARE EFFECTS . . . . . . . . . . . . 98

4.3.1 Introduction ................. 98

1.3.2 Comparative Imparts. . .............. 99

4.3.3 Air Pollution Generation . . . . . . . . . 104

4.3.4 Climatic Changes Due to Air Pollution Emissions. •. . 104

4.3.5 Thermal Discharges and Resulting Climatic Chànge... 106

4.3.6 Water Pollution. ............... 107

4.3.7 Water Use Changes. . . .............. 108

4.3.8 Solid Waste Generation ........... . . 108

4.3.9 Land Use Changes................... 109

4.3.10 Noise Generation . . . . . . . . . . . . 109

4.3.11 Electromagnetic Disturbances . . . . . . . . . 110

4.3.12 Radioactive Emissions. . . . . . . . . . . 110

4.3.13 Microwave Radiation. . . . . . . . . . . . . 111

4.3.14 Aesthetic Disturbances . . . . . . . . . . . . Ill

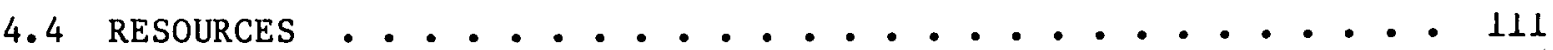

4.4 .1 Land ...................... . . 113

4.4 .2 Matorials................... 115

4.4.3 Energy .................... . . 116

4.4 .4 Water. . . . . . . . ...... 120

4.4 .5 Labor. . . . . . . . . . . . . . 122

4.5 MACROECONOMIC AND SOCIOECONOMIC ISSUES . . . . . . . . . 122

4.6 InStitulitonAL ISSUES . . . . . . . . . . . . . . . 124

4.6.1 Introduction. . . . . . . . . . . . . . 124

4.6.2 Comparison of Present Regulatory Schemes........ 125

4.6.3 Kegulatory Trends.................. 133

4.6.4 Summary . . . . . . . . . . . . . . 135

5 ASSESSMENT STATUS AND FUTURE DIRECTION . . . . . . . . . . 137

5.1 TECHNOLOGY SELECTION AND ChARACTERIZATION . . . . . . . . . 137

5.2 COMPARATIVE ISSUE STATUS AND FUTURE DIRECTION . . . . . . . . 137

REFERENCES. . . . . . . . . . . . . . . . . . 147

BIBLIOGRAPHY. . . . . . . . . . . . . . . . . 157 


\section{LIST OF FIGURES}

No.

1 Levelized Life-Cycle Costs.

xvi i

2 Front-End Costs of the SPS

xvi i.i

2.1 Analysis Sequence for Comparative Assessment . . . . . . . . . . . 6

2.2 Comparative Assessment Classification System . . . . . . . . . . . 8

3.1 Satellite Power System Concept . . . . . . . . . . . . . . . . 17

3.2 SPS Satellite Configurations . . . . . . . . . . . . . . 18

3.3 SPS Efficiency Chain . . . . . . . . . . . . . . . . . 19

3.4 Photovoltaic Plant Performance Chain . . . . . . . . . . . . . . 22

3.5 Coal Steam Plant with Wet Gas Scrubbing. . . . . . . . . . . 23

3.6 Basic Flow Scheme for Limestone Scrubbing Processes. . . . . . . . 26

3.7 Coal-Gasification/Combined-Cycle Electric Power Plant. . . . . . . 27

3.8 Simplified LWR Flow Diagram. . . . . . . . . . . . . . . . . 30

3.9 Fuel Cycle for the Liquid-Metal, Fast-Breeder Reactor. . . . . . 33

3.10 LMFBR Plant Schematic. . . . . . . . . . . . . . . . . . . . . . 34

3.11 LMFBR Radioactive Waste Systems . . . . . . . . . . . . . . . . 36

3.12 A Generic Fusion Reactor . . . . . . . . . . . . . . . 38

3.13 Fusion Plant Concept... . . . . . . . . . . . . . . 39

4.1 Assumed Fuel Costs . . . . . . . . . . . . . . . . . . . . 55

4.2 Levelized Life-Cycle Costs . . . . . . . . . . . . . . . 58

4.3 Annual System Generation Costs: Zero Fuel Price Escalation. . . . 62

4.4 Annual System Generation Costs: Low Fuel Price Escalation . . . 62

4.5 Annual System Generation Costs: Medium Fuel Price Escalation. . 63

4.6 Annual System Generation Costs: High Fuel Price Escalation. . . . 63

4.7 Comparison of Real and Estimated Costs of 2.2 NASA Space
Projects and Apollo. . . . . . . . . . . . . . . . . . . . . . . 68

4.8 Cost Growth in Pioneer Energy Process Plants . . . . . . . . . . . 69 
No.

4.9 Projections of Solar Cell Cost, Cents/Peak Watt . . . . . .

4.10 Distributions of the Sum of Cost Elements . . . . . . . . 73

4.11 Impact Severity Categories for Energy System Health and Safety Issues in Comparison to Risks from Other Causes. . . . .

4.12 Satellite Power System: Health \& Safety Issue Identification . • 86

4.13 Light Water Reactors with Fuel Reprocessing: Health and Safety Issue Identification ...............

4.14 Coal Gasification/Combined Cycle: Health and Safety

Issue Identificalión. . . . . . . . . . . . . . . .

4.15 Central Terrestrial Photovoltaic System:

Health and Safety Issue Identification. . . . . . . . . . 91

4.16 Fusion: Health and Safety Issue Identification . . . . . . . 93

4.17 Total Impacts of the Five Energy Systems. . . . . . . . . . . . 94

4.18 Public Impacts of the Five Energy Systems . . . . . . . . . . 96

4.19 Impacts of Component Production and Facility Construction of the Five Energy Systems . . . . . . . . . . . . 97

4.20 Pathway of Energy Activities, Impacts, and Effects. . . . . . 100

4.21 Schematic of Energy Balance . . . . . . . . . . . . . 117 
1 Developmental Status of the Technologies Selected for Comparison. . xv

2 Cost and Technology Assumptions for Year 2000 Technologies. . . . . xvi:

3 Summary of Land Requirements. . . . . . . . . . . . . . . . xxii

4 Cost and Performance -- Status, Uncertainties, and

Future Direction. . . . . . . . . . . . . . . . . . . . . xxiii

5 Health and Safety -- Status, Uncertainties, and Future Direction. . xxiv

6 Environmental Welfare -- Status, Uncertainties, and

Future Direction. . . . . . . . . . . . . . . . . . . . . . xxv

7 Resources -- Status, Uncertainties, and Future Direction. . . . . xxvi

8 Economic/Societal Issues -- Status, Uncertainties, and

Future Direction. . . . . . . . . . . . . . . . . . . xxvii

9 Institutional Issues - Status, Uncertainties, and Future

Direction . . . . . . . . . . . . . . . . . . . . xxviii

2.1 Candidate Alternative Technologies . . . . . . . . . . . . . . 9

3.1 Technologies Considered in Initial Screening. . . . . . . . . . . 12

3.2 Quantitative Screening of Energy Systems. . . . . . . . . . . . 13

3.3 Initial Screening of Electric Generation Technologies . . . . . . . 14

3.4 Final Technology Selection Decision Matrix. . . . . . . . . . . 15

3.5 SPS Cell and Planform Power Characteristics . . . . . . . . . 20

3.6. Approximate Component Areas Required for a 1,250 MWe

Reference Coal Plant. . . . . . . . . . . . . . . . . 25

3.7 Reference Coal Plant Air Emissions. . . . . . . . . . . . . 26

3.8 LWR Liquid and Gaseous Radioactive Enissions. . . . . . . . . . . . 32

3.9 Thermodynamic Characteristics of LMFBR Steam Cycle. . . . . . . . 35

3.10 Estimated Radionuclide Releases from a 1,250 MWe

LMFBR Reference Plant . . . . . . . . . . . . . . . . 37

3.11 Boeing and Rockwe11 Capital Cost Estimates for Construction of an Average 5-GWe Satellite Power System. . . . . . . . . . . . . 41

3.12 Construction Cost Summary: SPS and Alternative Technologies. .. . . 42 


\section{LIST OF TABLES (Cont'd)}

No.

Title

Page

3.13 Capital Costs for Major Alternatives... . . . . . . . . . . 45

3.14 Annual Operation and Maintenance Costs. . . . . . . . . . . 46

4.1 Capital Structure and Economic Assumptions. . . . . . . . . . . 50

4.2 Estimated Range of Capital Costs for Year-2000 Technologies... . 51

4.3 Summary of Capital Cost and Technology Assumptions for

Year-2000 Techuulogies. . . . . . . . . . . . . . . . . 54

4.4 Levelized Annual' Generation Revenue Requirements for Operation Beginning in 2000 . . . . . . . . . . . . . . . 57

4.5 Installed Capacity. . . . . . . . . . . . . . . . 60

4.6 Fuel Price Escalations. . . . . . . . . . . . . . . . . . 60

4.7 Annual System Generation Costs, Last Year of Expansion. . . . . . 64

4.8 Levelized System Generation Costs . . . . . . . . . . . . . . . 64

4.9 Economically Competitive SPS Capital Costs. . . . . . . . . . 66

4.10 Summary of Cost Estimating Experience for Various

Late Piujpils. . . . . . . . . . . . . . . . . . . . . . 70

4.11 Estimated Range of Rockwell Costs . . . . . . . . . . . . . . 72

4.12 Cost Comparison for the Photovoltaic Overview, by Plant Type,

Out put, and Cell Type . . . . . . . . . . . . . . . 77

4.13 Severity Indices for Individual Health and Safety Issues. . . . . 82

4.14 Uncertainty Indices . . . . . . . . . . . . . . . . 83

4.15 Welfare Effects of Coal-Combustion Fuel Cycle . . . . . . . . 101

4.16 Welfare Impacts of Nuclear Power Generation . . . . . . . . . 102

4.17 Welfare Effects of Satellite Power System . . . . . . . . . . 103

4.18 Potential Severity of and Status of Knowledge about

Key Environmental Welfare Issues. . . . . . . . . . . . . . 105

4.19 Summary of Preliminary Comparative Assessments -- Resources . . . . 112

4.20 Summary of Land Requirements. . . . . . . . . . . . . . . . 114

4.21 Summary of Energy Balance Data. . . . . . . . . . . . . . 119 


\section{LIST OF TABLES (Cont'd)}

No. Title

$\underline{\text { Page }}$

4.22 Issues Concerning Water Resource Requirements and Impacts . . . . . 121

4.23 Water Resource Requirements for SPS and Alternative Technologies. . 121

4.24 Justifications for Regulating Coal Technologies

at Each Level of Government . . . . . . . . . . . . . . . . . 127

4.25 Justifications for Regulating Light Water or Breeder

Reactors at Each Level of Government. . . . . . . . . . . . . . 128

4.26 Justifications for Regulating Terrestrial Photovoltaics

at Each Level of Government . . . . . . . . . . . . . . . . . . . 129

4.27 Justifications for Regulating SPS at Each Level of Government . . . 130

4.28 Comparative Cost Estimates for Federal Regulations of Coal and

Light Water Reactor Electricity Production Systems. . . . . . . . . 132

5.1 Cost and Performance -- Status, Uncertainties, and

Future Direction. . . . . . . . . . . . . . . . . 138

5.2 Health and Safety -- Status, Uncertainties, and

Future Direction. . . . . . . . . . . . . . . . 139

5.3 Environmental Welfare -- Status, Uncertainties

and Future Direction. . . . . . . . . . . . . . . . . . . . . 140

5.4 Resources -- Status, Uncertainties, and Future Direction .. . . . 141

5.5 Economic/Societal Issues -- Status, Uncertainties, and

Future Direction. . . . . . . . . . . . . . . . . . . . . . . 142

5.6 Institutional Issues -- Status, Uncertainties, and

Future Direction. . . . . . . . . . . . . . . . . . . . . . 143 


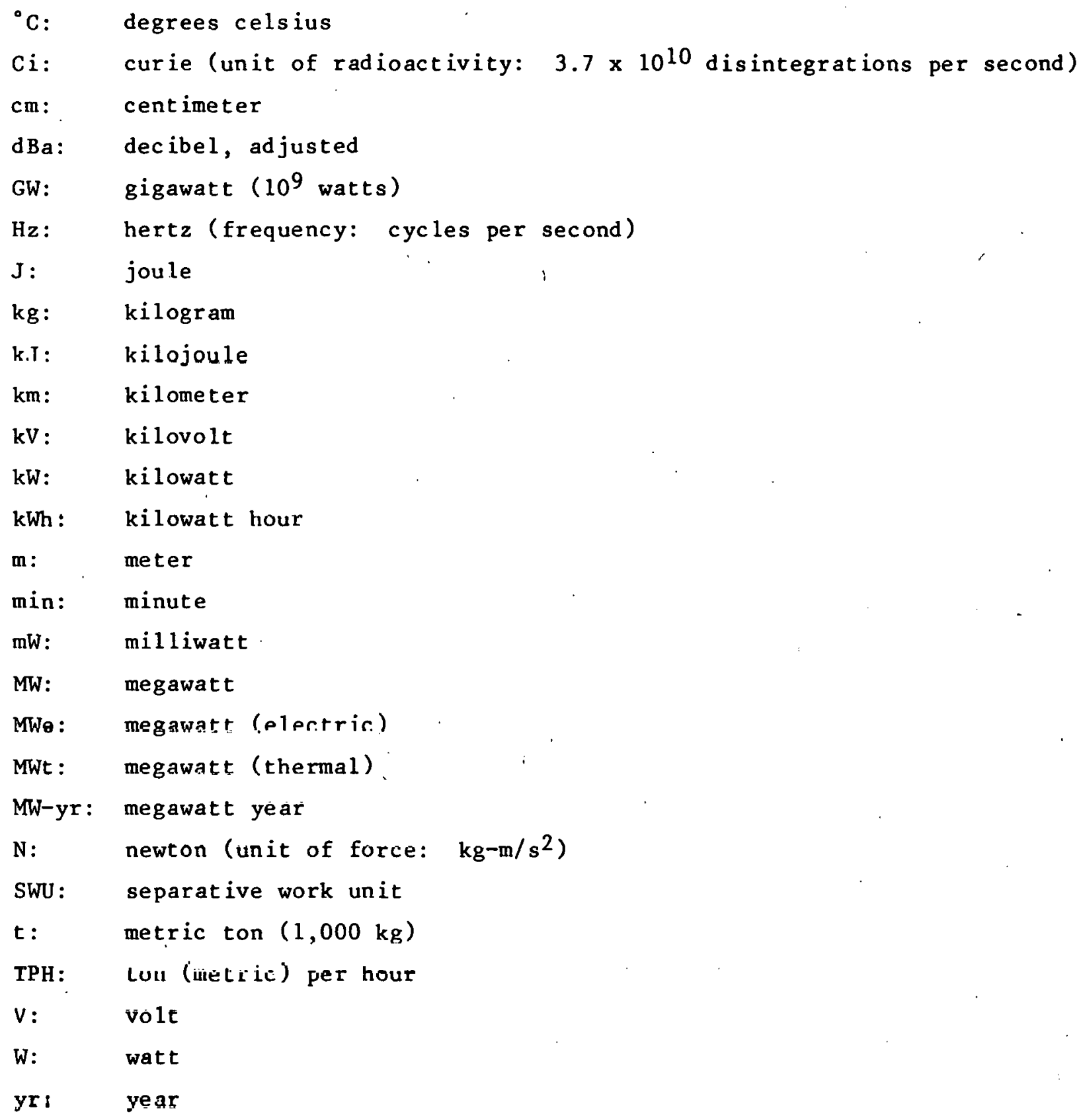


The SPS Concept Development and Evaluation Program (CDEP) was established by the Department of Energy (DOE) and the National Aeronautics and Space Administration (NASA) to generate information by which a rational decision could be made regarding the direction of the Satellite Power System (SPS) program after fiscal 1980. The four functional areas within the joint DOE/NASA-CDEP are as follows :

- Systems Definition: development of the SPS reference system design.

- Environmental Assessment: evaluation of potential environmental effects of SPS.

- Societal Assessment: evaluation of potential societal effects of SPS.

- Comparative Assessment: development of a comparative data base on the SPS and six other energy technologies.

The results of the first three activities are inputs to the comparative assessment process as well as independent program assessments.

This report concerns the comparative assessment portion of the CDEP. The objective of the comparative assessment is to develop an initial understanding of the SPS with respect to a limited set of energy alternatives. This is consistent with the overall. CDEP objective: to determine whether the SPS concept is sufficiently attractive (presenting no insurmountable barriers) to receive further research investment.

In all comparative assessments it is vital that the assumptions, uncertainties, and significant differences between the systems being compared be clearly and objectively presented. Otherwise the comparison may prove unacceptable for meaningful decisions. The key assumptions made and ground rules followed in this report are:

1. The baseload electric generation technologies are projected to be on line in the year 2000, with an approximate availability date of 1990. Further, the R\&D base and the infrastructure are assumed to be in place when required.

2. All data are traceable to publicly available information.

3. Each technology is treated as an independent variable. For example, if coal costs go up or down, the costs of the other technologies are assumed not to change for the same reasons.

4. When no historical data or basic reports were available, the analysts specified conditions chosen and presented their rationale. In cases where the chosen conditions have favored or disfavored a technology, the analysts have stated the bias. 
The SPS, fusion, and central-station solar photovoltaics technologies have received less engineering design and $R \& D$ attention than the other technologies examined in this assessment. Therefore, they are subject to larger uncertainty as well as greater optimism. Further, the 1 ife cycle costs of these three technologies are reduced by the second part of the first assumption, since the $R \& D$ and infrastructure costs are not addressed explicitly.

The third assumption tends to exaggerate cost overlap, but taking correlated characteristics into account was not feasible in this study. The choices made under the fourth assumption tend to favor the two solar technologies and fusion.

Because of the limited data available, under the assumptions, for some of the technologies (particularly fusion), it was not possible to compare all six alternatives to the SPS in all issue areas. The comparisons that were made in each issue area are noted in the relevant sections of this report. l'he tinal assessment will include more complete comparisons.

The intent is to compare SPS to each of the other six technologies, or to subsets of the six, or to all six technologies together. The limitations resulting from the assumptions preclude other comparisons. Within these assumptions and ground rules, the six limited but representative energy technologies were selected, characterized, and documented. These data were normalized to unit bases, such as dollars per megawatt or environmental residuals per megawatt, and alternative futures were compared (i.e., possible technology mixes, supply and demand cases, and resultant environmental, resource, and cost uncertainties).

The technology alternatives selected for this assessment were limited to the following:

- Improved conventional coal technology

- Pressurized 1 ight water reactór (LWR)

- Coal gasification/combined cycle (CG/CC)

- Liquid-metal, fast-breeder reactor (LMFBR)

- Central station, terrestrial photovoltaic (TPV)

- SPS

- Fusion (magnetically confined)

These selections were considered to be the most representative set of year 2000 energy lechnologies for comparison to the SPS reference system.

A six-step comparative methodology is described briefly in this report and more thoroughly in a companion report.1 This assessment included only the first four of the six steps (i.e., selection of alternatives, issue selection, system characterizations, and side-by-side analysis), resulting in what is referred to as a preliminary side-by-side assessment. It is "preliminary" because the basic comparative data are expected to be improved and updated in the subsequent comparative assessment, and "side-by-side" because it is a normalized comparison (i.e., per unit energy output) based on assumptions about the economic status of the nation in the beginning of the 21 st century. 
The subsequent assessment will include an alternative futures comparison, which will define ranges of plausible economic-energy futures and make the comparisons based on these conditions to show what effects the assumptions (e.g., energy demand) have on the viability of the SPS in the future.

Included in this document are (1) a brief description of the comparative methodology, (2) brief characterizations of the alternative technologies, (3) side-by-side comparisons in six issue areas, and (4) a discussion of assessment status and future directions.

The six issue areas used for side-by-side comparisons were (1) cost and performance, (2) health and safety, (3) environmental welfare, (4) resources, (5) macroeconomics and socioeconomics, and (6) institutional issues. The comparisons were performed for technologies that are at different stages of development - current, near-term, and advanced -- and therefore have different degrees of information available (e.g., actual vs. projected construction data). Table 1 lists development and experience levels for the technologies evaluated in this preliminary assessment. Capital cost uncertainty ratings and cost uncertainty issues are also listed. These cost uncertainty ratings ( 1 = certain; 5 = extremely uncertain) were developed on the basis of existing relevant documentation and on the judgment of the assessment participants.

Table 1. Developmental Status of the Technologies Selected for Comparison

\begin{tabular}{|c|c|c|c|}
\hline Technology & $\begin{array}{l}\text { Units } \\
\text { in } \\
\text { Operation }\end{array}$ & $\begin{array}{c}\text { Capital Cost } \\
\text { Uncertainty } \\
\text { Rating }\end{array}$ & $\begin{array}{l}\text { Cost } \\
\text { Uncertainty } \\
\text { Issues }\end{array}$ \\
\hline $\begin{array}{l}\text { Conventional } \\
\text { Coal }\end{array}$ & $>100$ & 2 & Fue $1, \mathrm{ECT}^{\mathrm{b}}$ \\
\hline LWR & $>50$ & 2 & Fue 1, ECT \\
\hline Cof/cr. & 5 & .3 & Fue 1 \\
\hline LMFBR & 5 & 3 & Fuel, ECT \\
\hline TPV & 0 & 4 & $\begin{array}{l}\text { Materials, } \\
\text { Efficiency }\end{array}$ \\
\hline SPS & 0 & $4-5$ & $\begin{array}{l}\text { Materials, ECT, } \\
\text { Space Transport, } \\
\text { and Construction } \\
\text { O\&M }\end{array}$ \\
\hline Fusion & 0 & $4-5$ & $\begin{array}{l}\text { Materials, Con- } \\
\text { tainment Design, } \\
\text { ECT }\end{array}$ \\
\hline
\end{tabular}

$a_{1}=$ certain; 5 = extremely uncertain.

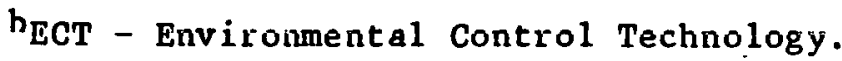


As stated earlier, the information presented and developed in these comparisons has been derived from published research and information found in the literature for the various technologies. However, in some instances, data have not been available from such sources, and it has been necessary to develop these data either through analysis. or on the basis of engineering judgment. In these instances, the rationales are explained and the inherent uncertainties duly noted.

Cost and performance characterization data for the alternative technologies are presented briefly in Sec. 3 and form the basis for the side-byside comparisons that are reported in Sec. 4. Cost data for the SPS were obtained from NASA-sponsored Boeing and Rockwell systems design efforts.* Cost estimates for the alternative technologies were developed from reference design reports.*

\section{Cost and Performance}

A summary of costs associated with each of the technologies under consideration is shown in Table 2 and illustrated in Fig. 1 . The total costs of power production for the more highly developed technologies (coal, LWR, CG/CC, and LMFBR) overlap considerably, as indicated on Fig. 1. Power produc$t$ ion costs for the technologies based on renewable resources (terrestrial photovoltaic, fusion, and SPS) tend to be higher, as well as in a wider range due to the inherent uncertainties of capital cost estimation. Uncertainties are, of course, the key factor in these production cost estimates. Depending on the magnitude of capital costs and fuel costs, the costs of power from the renewable-resource technologies could ultimately be either within range of, or a large multiple ot, the more highly developed technologies.

The following key cost drivers and factors affecting uncertainty were identified in the analysis:

- SPS: capacity factor, technology performance, O\&M cost, cell cost

- TPV: cell production efficiency, cell cost, capacity factor

- CG/CC: gasifier cost, fuel price

- LMFBR: fue 1 price

- Conventional coal: fuel price

- LWR: fuel price

- Fusion: scientific uncertainty regarding plasma containment

\footnotetext{
* Base costs were accepted as reported. 2-6 Cost adjustments were made to put all costs on the same basis (e.g., ownership assumptions and siting) and to normalize costs to the same power level. No adjustment was made to the base cost numbers to account for perceived optimism about the costs of developing technologies.
} 
Table 2. Cost and Technology Assumptions for Year 2000 Technologies*

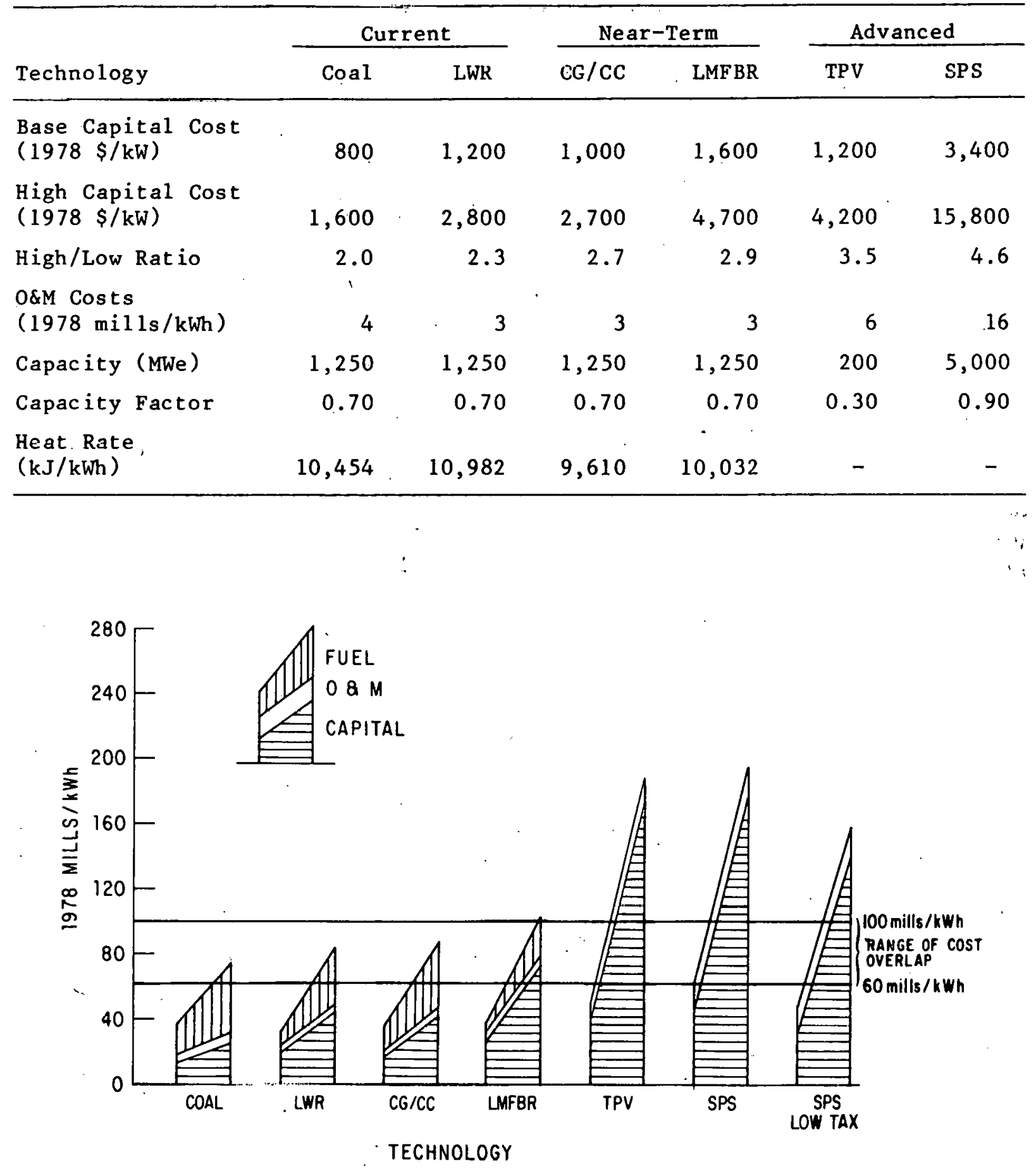

Fig. 1. Levelized Life-Cycle Costs*

*Fusion data were not readily available for this preliminary assessment. 
In comparing costs, it should be noted that the SPS Reference System was developed to guide the assessments and has not been optimized with regard to environmental, economic, or societal benefits. This is also true for the reference systems selected for the alternative concepts. Should the SPS concept, and thus system.design options and tradeoffs, continue to be evaluated, it is expected that its projected costs will change.

\section{Development Costs}

Boeing estimated front-end costs on the basis of the reference system scenario, which is predicated on a 20-year development schedule and a 30-year deployment schedule (60 5-GW satellites).6a These costs amount to $\$ 100-110$ billion and are broken down as follows (Fig. 2):

- Research costs: mainly ground-based research to ardress environmental and social issues and alternative systems, resulting in a preferred system;

- Engineering: development and testing of prototype subsystems, resulting in specifications for demonstration units and production facilities;

- Demonstration: flight tests of a 100-200 MW unit integrated with a commercial network;

- Investment: development of industrial infrastructure, e.g., transportation, photovoltaic, and klystron manufacturing facilities.

- Cuistrucliun and Implementation: the first 5-GW SPS unit pur into place.

It is importanl to noce that these cost estimateo asoume that all effort is specific to the SPS. The benefits from Eeneric research or frum

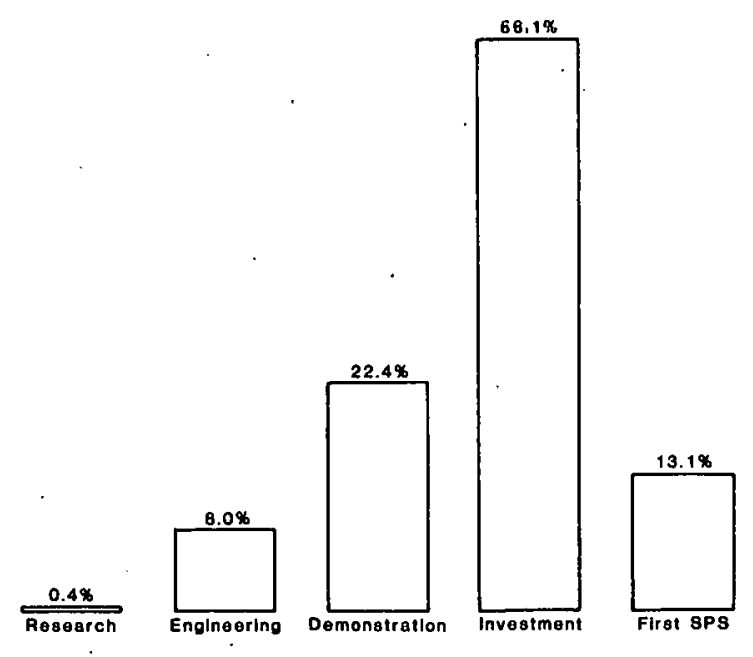

Fig. 2. Front-End Costs of the SPS (Source: Ref. 6b) 
cost sharing (e.g., industry or other federal program support for photovoltaics manufacturing facilities) have not been considered. Such cost modifications could amount to $50-70 \%$ of the $\$ 102.5$ billion. $6 \mathrm{c}$

Since comparable cost data for the other six technologies were not available, side-by-side comparisons of costs or of the benefits or disadvantages of public expenditures were not attempted.

\section{Health and Safety}

The comparison of health and safety aspects of advanced and current technologies is not possible on a total risk basis because of the uncertainties and unquantifiable impacts for all the technologies, even current coal and nuclear technologies. The health and safety issues presented in Sec. 4.2 can best be summarized as follows:

- All the technologies will have distinct health and safety impacts.

- It is difficult to quantify and assess the low-level and delayed impacts of all the technologies.

In general, the more defined technologies (e.g., coal, LWR) have a greater number of quantifiable risks and fewer unquantifiable risks. The opposite is true for the less-defined technologies (e.g., fusion, SPS). In contrast to the apparent public willingness to accept limited known risks of energy systems, recent experience with light water fission systems indicates that perceived major risks that are less quantifiable or predictable may restrict or completely halt energy system deployment if adequate assurances of low impact probability cannot be given. In this study, health and safety issues potentially of major concern but currently unquantifiable were placed into two general categories as follows:

1. Low levels of pollutants or radiation, which impose, at most, small individual risks that are not well understood. However, an exposure of a large number of persons and cumulalive effects are of concern.

- Low-level ionizing radiation from fission reactors.

- Coal combustion air pollutants that are transported long distances.

- Low-level microwave (nonionizing)* radiation from the SPS.

2. Catastrophic events with a probability of occurrence that is thought to be low.

- Large radiation release from a major fission reactor accident.

*Microwave radiation is nonionizing; nuclear radiation is ionizing. 
- Diversion of nuclear materials from fission reactors for use as weapons.

- Inadvertent acute exposure of a large population to SPS microwave radiation.

- Crash of an SPS heavy-lift launch vehicle or a low earth orbit vehicle into an urban area.

\section{Environmental. Welfare Effects}

Effects not related to health and safety are classified here as environmental welfare effects, e.g., weather modification by carbon dioxide; materials degradation, electromagnetic interference with communications, aesthetics, and noise. In the side-by-side comparison, only qualitative evaluations of the effects were made. For some issues, definitive work has been done, e.g., SPS electromagnetic interference. Although the $\mathrm{CO}_{2}$ problem is much" discussed, there is certainly no consensus on the risks involved.

\section{Resources}

Resource comparisons in this assessment were limited to net energy, materials, and land. The net energy analysis showed that all the technologies are net energy producers if the thermal fuel value of non-renewable fuels is not considered. The SPS and TPV become more efficient producers as the energy efficiency of all production improves (e.g., SPS could go from a 6-year to a 1.5-year payback period for a silicon system). An SPS system utilizing gallium aluminum arsenide was compared to the silicon syetem and looks promising, but very little information is available to support this compar1son.

Each technology (with the exception of the LMFBR) has material requirements that could be considered critical because of environmental control requirements or limited production capability. However, none of these materials appears to be limiting, but a thorough materials assessment based on materials demand and supply, including world demand forecasting, has not. hepn. done.

Water use by the SPS and TPV is minimal in comparison to that by coal and nuclear systems. Even coal and nuclear systems dn nnt have overall water limitations, but siting is constrained by the availability of water.

Land use was compared on the basis of quantity, duration, and location, and the comparisons were broken down by the different phases of the fue 1 cycle. The total amount of land required for the complete fuel cycle is roughly the same for all technologies (for SPS and TPV, a lit.te larger). However, the SPS and TPV require large blocks of contiguous 1 and and may involve additional long distance transmission. because of remote siting, which could cause additional difficulties. A more siting-oriented land use study for all the technologies would be more useful because it would identify the particular land areas that would be disrupted, or consumed. Table 3 summarizes these land requirements. 


\section{Institutional Issues}

Only regulatory issues were addressed in this preliminary assessment. The SPS, fusion, and other advanced systems may be difficult to operate in the current regulatory climate. The SPS could be additionally burdened by international regulations that do not appear to limit the other technologies.

\section{Status and Future Direction}

This preliminary assessment was designed to provide input into the final comparative assessment in the final CDEP assessment. As such, it is inappropriate to formulate strong conclusions as to the comparative position of SPS based on this report. Tables 4 through 9 display the key issue findings in this preliminary study, the uncertainty, and the future study effort aimed at reducing the uncertainty. However, the final comparative assessment, combined with the other three CDEP assessment studies, will be required to respond to $\mathrm{CDEP}^{\prime}$ s objective of determining whether there are. any insurmountable barriers to SPS that preclude further R\&D concerning the decision on whether SPS technology development should be continued. 
Table 3. Summary of Land Requirements

\begin{tabular}{|c|c|c|c|c|c|}
\hline Purpose & Construction & Plant & Fuel & Disposal & Transmission \\
\hline \multicolumn{6}{|l|}{ LWR } \\
\hline Quantity & $\mathbf{a}$ & $57-174 m^{2} / 11 w-y r$ & $31 \mathrm{~m}^{2} / \mathrm{llw}-\mathrm{yr}$ & $4 m^{2} / 11 w-y r$ & $\begin{array}{c}225-1,000 \mathrm{~m}^{2} / \mathrm{MW}-\mathrm{yr} \\
(480-1,600 \mathrm{~km})^{\mathrm{b}}\end{array}$ \\
\hline Duration & $--c$ & $30-40$ y r & $30 \mathrm{yr}$ & $10^{6} \mathrm{yr}$ & $30-40$ yr \\
\hline Location & $--c$ & $--c$ & $--c$ & $--c$ & $--c$ \\
\hline \multicolumn{6}{|l|}{ co/ces } \\
\hline Quantity & $\mathbf{a}$ & $7.2-150 \mathrm{~m}^{2} / \mathrm{mW}-\mathrm{yr}$ & $\begin{array}{l}1,800-4,520 \\
\mathrm{~m}^{2} / \mathrm{NW}-\mathrm{yr}\end{array}$ & $5 n^{2} / n w-y r$ & $\begin{array}{c}300 \mathrm{~m}^{2} / \mathrm{NW}-\mathrm{yr} \\
(480 \mathrm{~km})^{b}\end{array}$ \\
\hline Duration & $--c$ & $30 \mathrm{yr}$ & 30 yr & $--c$ & $30 \mathrm{yr}$ \\
\hline Location & $--c$ & $-c$ & $--c$ & $--c$ & $--c$ \\
\hline \multicolumn{6}{|l|}{ LHIFBR } \\
\hline Milanriry & a & $76-1,33 \mathrm{~m}^{2} / 116 \mathrm{yt}$ & $\begin{array}{l}5 \mathrm{~m}^{2} / l w-y \mathrm{r}^{2} \\
\text { (plant l1fe- } \\
\text { lime) and } \\
0.25 \mathrm{~m}^{2} / \mathrm{lW}-y \mathrm{r} \\
\text { (permanent) }\end{array}$ & $--i$ & $\begin{array}{l}200 \mathrm{~m}^{2} / \mathrm{llw}-\mathrm{yr} \\
(00 \mathrm{~km})^{b}\end{array}$ \\
\hline Duration & $--c$ & $30 \mathrm{yr}$ & $--c$ & $--c$ & 30 yr \\
\hline Location & $--c$ & $--c$ & $--c$ & $-\infty c$ & $--c$ \\
\hline \multicolumn{6}{|l|}{ TPV } \\
\hline Quanitity & $\mathbf{a}$ & $\begin{array}{l}600-3,800 \mathrm{~m}^{2} / \mathrm{MW}-\mathrm{yr} \\
\text { (depending on ce } 11 \\
\text { efficiency and } \\
\text { capacity factor) }\end{array}$ & negld & neg $1^{d}$ & $\begin{array}{c}300-3,000 \mathrm{~m}^{2} / \mathrm{llw}-y \mathrm{r} \\
(480-4,800 \mathrm{kIn})^{\mathrm{b}}\end{array}$ \\
\hline Duration & $--c$ & 30 y r & $\mathrm{NA}^{\mathrm{e}}$ & $\mathrm{N} \Lambda^{\mathrm{e}^{\prime}}$ & $30 \mathrm{yi}$ \\
\hline Location & $--c$ & Southwest & $N A^{e}$ & NA ${ }^{e}$ & $--c$ \\
\hline \multicolumn{6}{|l|}{ SPS } \\
\hline Quantity & $\begin{array}{l}20-850 \mathrm{~km}^{2} \\
\text { (launch) }\end{array}$ & $\begin{array}{l}1,300 \mathrm{~m}^{2} / \mathrm{llw}-\mathrm{yr} \\
\text { (rectenna) } \mathrm{f}\end{array}$ & ney! d & neg $1^{d}$ & $\begin{array}{l}3 n n-1,0 n m^{2} / m \| W=y r \\
(480-1,600 \mathrm{kn})^{b}\end{array}$ \\
\hline Duiallult & $30 \mathrm{yr}$ & ju yr & $N \Lambda^{E}$ & $\mathrm{NA}^{\mathrm{e}}$ & 30 yr \\
\hline Location & Florida? & $--c$ & $N \Lambda^{e}$ & $\mathrm{NA}^{\mathrm{e}}$ & $--c$ \\
\hline
\end{tabular}

approximately the sum of plant and transmission requirenents.

bistance ro load center; see discussion in text.

c.- Vata lacking.

$d_{\text {negl - negliglble. }}$

eNA - Not applicahle.

$f$ Includes buffer zone; rectenna comprises $=50 \%$ of total. 
Table 4. Cost and Performance -- Status, Uncertainties, and Future Direction

\begin{tabular}{|c|c|c|c|c|}
\hline Systein & Status of Key Issues & Uncertainty & Future Direction & Comments \\
\hline $\begin{array}{l}\text { Coal } \\
\text { (Conven- } \\
\text { t1onal, } \\
\text { CG/CC) }\end{array}$ & $\begin{array}{l}\text { Capital cost is firm but the } \\
\text { fuel price is variable. }\end{array}$ & $\begin{array}{l}\text { The price range for coal } \\
\text { is large. }\end{array}$ & $\begin{array}{l}\text { The fuel cost depends on } \\
\text { the specific alternative } \\
\text { futures scenarios. }\end{array}$ & . \\
\hline $\begin{array}{l}\text { Fission } \\
\text { (PWR. } \\
\text { LMFBR) }\end{array}$ & $\begin{array}{l}\text { Capital cost is adequately } \\
\text { defined. } \\
\text { System performance has been } \\
\text { determined. }\end{array}$ & $\begin{array}{l}\text { The price range for uranium } \\
\text { is large. } \\
\text { Safety performance is } \\
\text { uncertain. }\end{array}$ & $\begin{array}{l}\text { The fuel cost depends on } \\
\text { the specific scenario. }\end{array}$ & 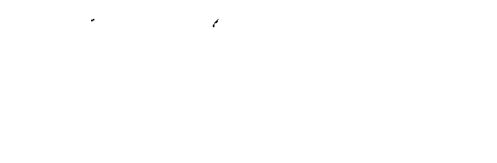 \\
\hline TPV & $\begin{array}{l}\text { System integration studies } \\
\text { have not been performed. } \\
\text { Distributed TPV have not } \\
\text { been analyzed. }\end{array}$ & $\begin{array}{l}\text { System cost uncertainty is } \\
\text { mainly due to cell cost } \\
\text { and performance. }\end{array}$ & $\begin{array}{l}\text { Perform system integration } \\
\text { and value-to-system analyses. }\end{array}$ & . \\
\hline SPS & $\begin{array}{l}\text { Deployment rate and regional } \\
\text { aspects were not considered. } \\
\text { Unit size and reliability } \\
\text { were not analyzed. }\end{array}$ & $\begin{array}{l}\text { The capital cost range is } \\
\text { large and inadequately } \\
\text { defined. O\&M costs are } \\
\text { highly uncertain. } \\
\text { System reliability is } \\
\text { unknown. }\end{array}$ & $\begin{array}{l}\text { Continue cost audits for } \\
\text { other parts of the SPS design. } \\
\text { Assess sensitivity to } \\
\text { implementation scenario and } \\
\text { infrastructure assumptions. } \\
\text { Develop better cost } \\
\text { comparisons. }\end{array}$ & $\begin{array}{l}\text { Cost ranges (not one cost num- } \\
\text { ber) based on technical and } \\
\text { economic performance should } \\
\text { be developed. } \\
\text { More refined system definition } \\
\text { costs are required. }\end{array}$ \\
\hline Fusion & $\begin{array}{l}\text { System neliability is } \\
\text { unknown. }\end{array}$ & $\begin{array}{l}\text { The cost range cannot be } \\
\text { determined. }\end{array}$ & $\begin{array}{l}\text { Nuwmak cost estimates to } \\
\text { be used in final assessment. }\end{array}$ & $\begin{array}{l}\text { Even with larye uncertainty } \\
\text { ranges, reliable costs cannot } \\
\text { be developed until plasma } \\
\text { confinement is achieved. }\end{array}$ \\
\hline $\begin{array}{l}\text { Compara- } \\
\text { tive } \\
\text { Analysis. }\end{array}$ & $\begin{array}{l}\text { TPV compares more favorably } \\
\text { to the SPS as cell efficiency } \\
\text { and cost improve. } \\
\text { Cost ranges overlap under } \\
\text { varying economic assumptions. }\end{array}$ & $\begin{array}{l}\text { Uncertainty analyses could } \\
\text { provide better cost com- } \\
\text { parisons than preliminary } \\
\text { side-by-side analyses. }\end{array}$ & $\begin{array}{l}\text { Further develop quantitative } \\
\text { uncertainty techniques and } \\
\text { comparisons. } \\
\text { Compare direct costs of } \\
\text { selected systems in } \\
\text { different scenarios. }\end{array}$ & $\begin{array}{l}\text { Cost comparisons should } \\
\text { focis on cost differences } \\
\text { between technologles. }\end{array}$ \\
\hline
\end{tabular}


Table 5. Health and Safety -- Status, Uncertainties, and Future Direction -

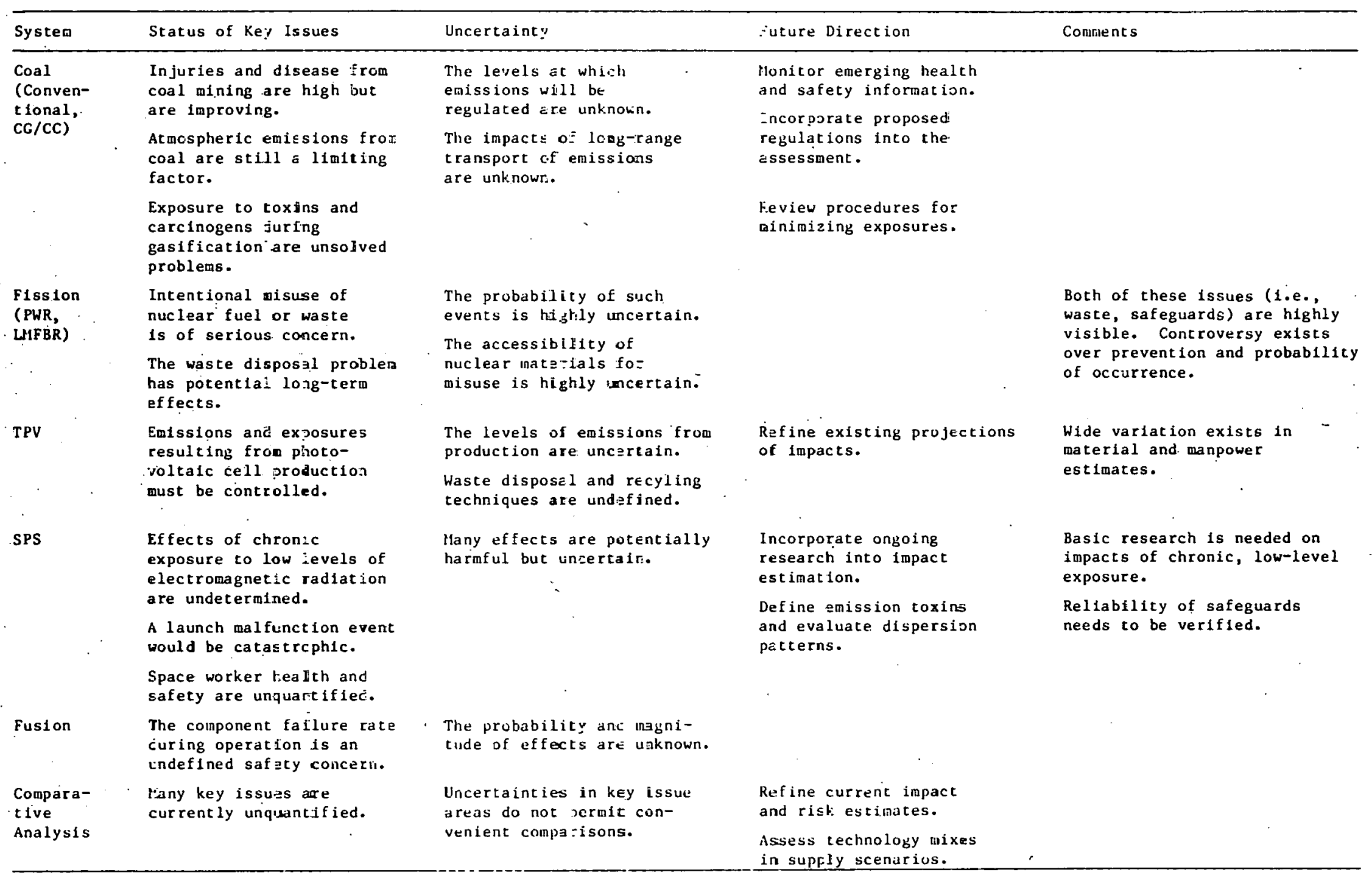


Table 6. Environmental Welfare -- Status, Uncertainties, and Future Direction

\begin{tabular}{|c|c|c|c|}
\hline System & Status of hey lssues & Uncertainty & future birection \\
\hline $\begin{array}{l}\text { Coal } \\
\text { (Conven- } \\
\text { tional. } \\
\text { (c/Cc) }\end{array}$ & $\begin{array}{l}\text { The ef fects of } U_{2} \text { thilssions } \\
\text { to the ditnosphere are of } \\
\text { serious concerithe }\end{array}$ & 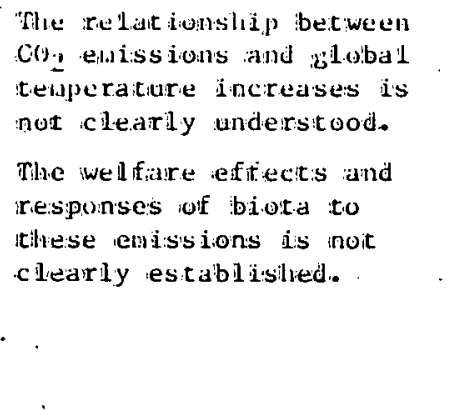 & 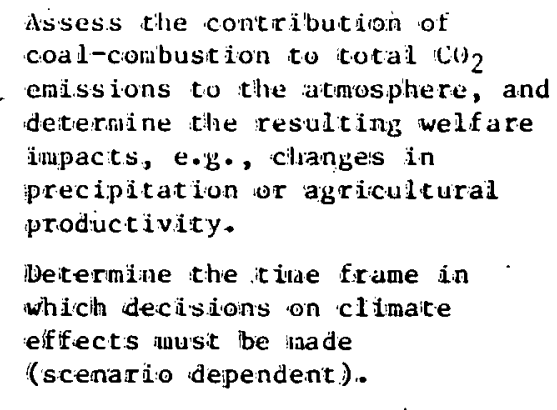 \\
\hline $\begin{array}{l}\text { Fissicn } \\
\text { ('PW:R, } \\
\text { (LIF:BR') }\end{array}$ & $\begin{array}{l}\text { Ropulation ditsplacenent due } \\
\text { to safety probiems should be } \\
\text { considered in Euture sit ing. }\end{array}$ & & $\begin{array}{l}\text { Detemine the impacts resulting } \\
\text { from retaote siting. }\end{array}$ \\
\hline TPV & $\begin{array}{l}\text { Not addiressed in } \\
\text { preliminary as:sessment. }\end{array}$ & & Identify impacts. \\
\hline SPS & 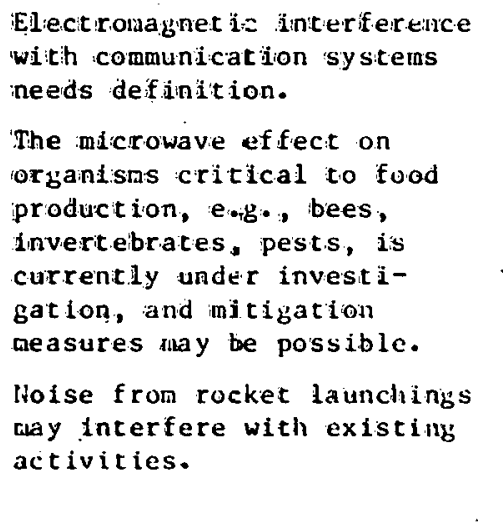 & $\begin{array}{l}\text { This inpact is dependent } \\
\text { on the location of the } \\
\text { launch complex, and the } \\
\text { frequency of laurclies. }\end{array}$ & $\begin{array}{l}\text { Examine the constraints on } \\
\text { land use near the rectenta. }\end{array}$ \\
\hline Fusion & $\begin{array}{l}\text { Not addressed in } \\
\text { prel itinary assesslitent }\end{array}$ & & Identify inpacts. \\
\hline $\begin{array}{l}\text { Compara- } \\
\text { tive } \\
\text { Analysis }\end{array}$ & 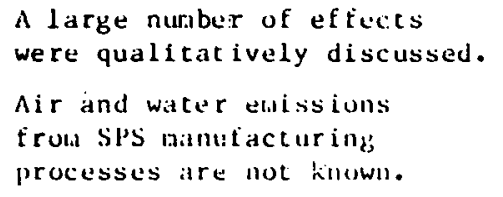 & $\begin{array}{l}\text { The extent of inpacts is } \\
\text { hidhly dependent on tanu- } \\
\text { facturing processes, } \\
\text { froduction rates, and } \\
\text { quantities of elaissions. }\end{array}$ & $\begin{array}{l}\text { Culipare cunulative lapacts } \\
\text { under scenario conditions. } \\
\text { Bracket costs for key issues. }\end{array}$ \\
\hline
\end{tabular}


Table 7. Resources -- Statis, Uncertainties, and Future Di=ection

\begin{tabular}{|c|c|c|c|c|}
\hline System & Status of Key Issues & Uncertainty & Future Direction & Comments \\
\hline $\begin{array}{l}\text { Coal } \\
\text { (Conven- } \\
\text { tonal, } \\
\text { CG/CC) }\end{array}$ & $\begin{array}{l}\text { Temporary land despo:lmert } \\
\text { due to coal mining. } \\
\text { Consumption of water for } \\
\text { cooling is a local problen. }\end{array}$ & $\begin{array}{l}\text { Design requirement: are } \\
\text { fairly well-characierized, } \\
\text { and there are no resource } \\
\text { constraints. } \\
\text { Social anc politiçel forces } \\
\text { may cause sone constraints. }\end{array}$ & $\begin{array}{l}\text { Develop scenarios to } \\
\text { verify that resource } \\
\text { demands are not critical. }\end{array}$ & $\cdot$ \\
\hline $\begin{array}{l}\text { Fission } \\
\text { (PWR, } \\
\text { LMFBR) }\end{array}$ & $\begin{array}{l}\text { The uranium supply will be } \\
\text { limited if there is no } \\
\text { breeder reactor. } \\
\text { Consumption of water for } \\
\text { cooling is a local problem. }\end{array}$ & $\begin{array}{l}\text { The technclogy is well- } \\
\text { characterized with regard } \\
\text { to resources. }\end{array}$ & $\begin{array}{l}\text { Develop scenarios :o dete:- } \\
\text { mine resource cons:raints } \\
\text { more specifically, e.g., } \\
\text { heavy reliance on LWK would } \\
\text { tax the uranium supply. }\end{array}$ & $\cdot$ \\
\hline TPV & $\begin{array}{l}\text { Large land } r \equiv q u i r e m e n c s \text { pase } \\
\text { serious sitiag problens. } \\
\text { Several potential problem } \\
\text { naterials have been } \\
\text { Identifled. } \\
\text { Silicon systeas are currently } \\
\text { highly energy-intensive. }\end{array}$ & $\begin{array}{l}\text { Cell efficiencies and the } \\
\text { energy intensity of cell } \\
\text { production are underermined. }\end{array}$ & $\begin{array}{l}\text { Specify regional or local } \\
\text { sites. } \\
\text { Assess likely imprcve- } \\
\text { ments in cell efficiency } \\
\text { and energy intensity of } \\
\text { cell production. }\end{array}$ & . \\
\hline SPS & $\begin{array}{l}\text { Large contiguous rectennas } \\
\text { pose serious siting probleus. } \\
\text { Several potential problem } \\
\text { materials have been } \\
\text { fdentified. } \\
\text { The satellite requires a new, } \\
\text { highly-trainej labor force. }\end{array}$ & $\begin{array}{l}\text { The extent of difíiculties } \\
\text { depends large iy on the } \\
\text { development scenarios, } \\
\text { rather than or uncer- } \\
\text { tainties within each } \\
\text { issue area. }\end{array}$ & $\begin{array}{l}\text { Develop scenarios to } \\
\text { deteruine any resou:ce } \\
\text { constraints. } \\
\text { Siting specification } \\
\text { is required. }\end{array}$ & $\begin{array}{l}\text { The nost serious resource } \\
\text { problem appears to be that } \\
\text { large contlguous land areas } \\
\text { may be only avallable in } \\
\text { remote locations. }\end{array}$ \\
\hline Fusion & $\begin{array}{l}\text { There is little informetion } \\
\text { about fusion, and preliminary } \\
\text { disigns lack substantive } \\
\text { detail. }\end{array}$ & $\begin{array}{l}\text { Current designs are not } \\
\text { likely ro entail resciurce } \\
\text { constraints. }\end{array}$ & $\begin{array}{l}\text { Further technology } \\
\text { characterization is needed. } \\
-\end{array}$ & $\begin{array}{l}\text { The likelihood of technical } \\
\text { success is the most serious } \\
\text { problem now, not resources. }\end{array}$ \\
\hline $\begin{array}{l}\text { Compara- } \\
\text { tive } \\
\text { Analysis }\end{array}$ & $\begin{array}{l}\text { The land-use comparison of } \\
\text { SPS with TPV cepends heavily } \\
\text { on cell efficiency. } \\
\text { Material and energy con- } \\
\text { straints do nct appear like-y } \\
\text { for any of these technologles. } \\
\text { Tre most serious resourie } \\
\text { issue for solar energy con- } \\
\text { cerns contiguols land } \\
\text { consumption. }\end{array}$ & · & $\begin{array}{l}\text { Develcp scenarios to permit } \\
\text { detailed investigation of } \\
\text { large-scale effects. } \\
\text { Develop more specific } \\
\text { siting information for SPS } \\
\text { \& TPV for land assessments. }\end{array}$ & $\begin{array}{l}\text { Further characterization is } \\
\text { needed to fill information } \\
\text { gaps on several technologies. }\end{array}$ \\
\hline
\end{tabular}


Table 8. Economic/Societal Issues -- Status, Uncertainties, and Future Direction

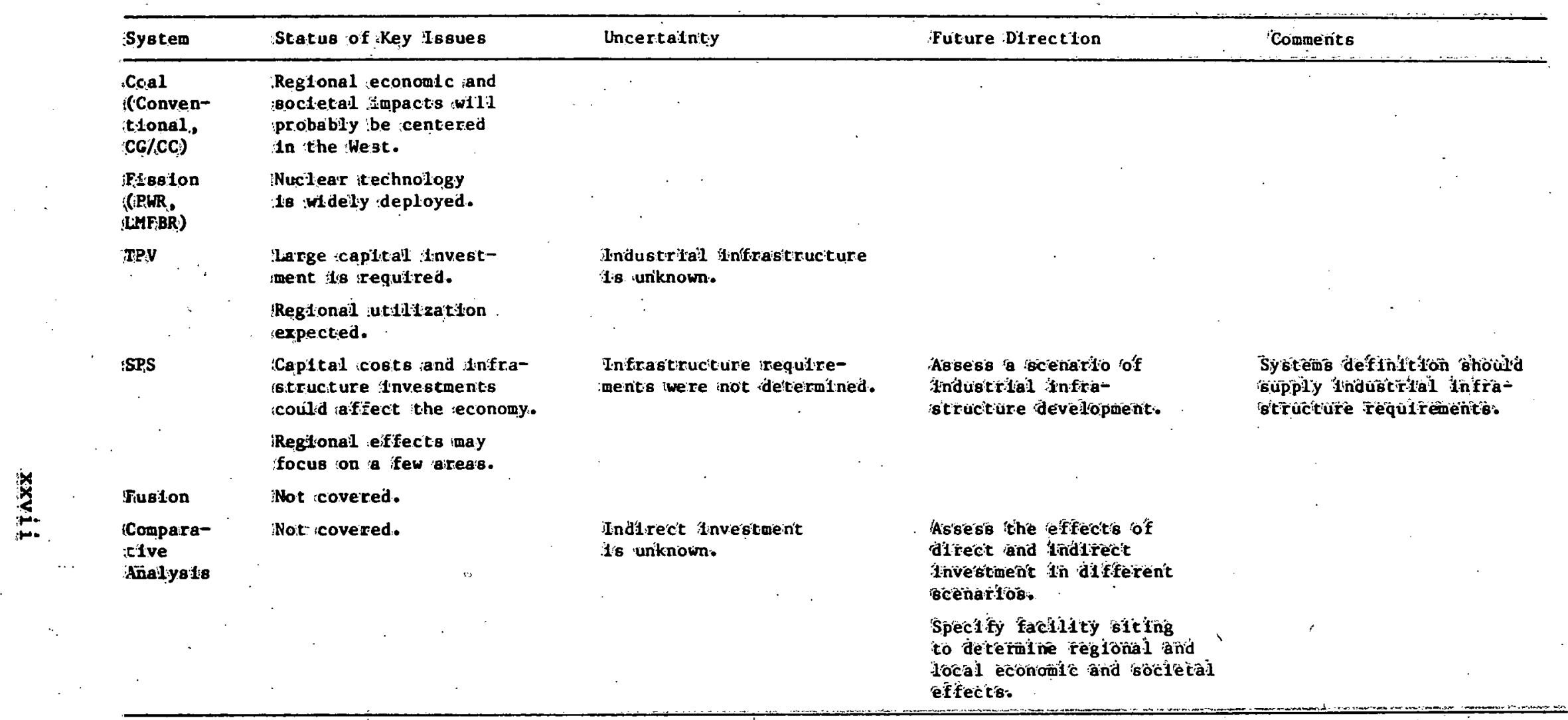


Table 9. Institutional Issues -- Status, Uncertainties, and Future Direction

\begin{tabular}{|c|c|c|c|c|c|}
\hline System & & Status of Key issues & Uncertainty & Future Direction & Combents \\
\hline $\begin{array}{l}\text { Coal } \\
\text { (Conven- } \\
\text { tional, } \\
\text { CG/CC) }\end{array}$ & & $\begin{array}{l}\text { Coal is already heavily } \\
\text { regulated. }\end{array}$ & & $\begin{array}{l}\text { Assess how the trend toward } \\
\text { decentralized decision } \\
\text { - making could affect the } \\
\text { deployment scenaris. }\end{array}$ & · \\
\hline $\begin{array}{l}\text { Fission } \\
\text { (PWR, } \\
\text { LMFBR) }\end{array}$ & & $\begin{array}{l}\text { The cost of regulation most. } \\
\text { likely will continue to } \\
\text { increase. }\end{array}$ & $\cdot$ & & . \\
\hline- & & $\begin{array}{l}\text { A continued =read to decen- } \\
\text { tralize decision making way } \\
\text { inhibit furtber deployment. }\end{array}$ & $\begin{array}{l}\text { The course o: tr:s trend } \\
\text { is unknown. }\end{array}$ & & $-\cdots$ \\
\hline TPV & & $\begin{array}{l}\text { This technolcigy faces few } \\
\text { current regulatcry barriers. }\end{array}$ & & . & 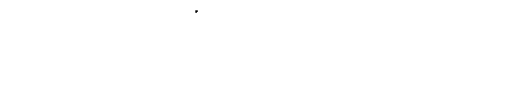 \\
\hline $\begin{array}{c}\text { SPS } \\
\ddots\end{array}$ & & $\begin{array}{l}\text { The current regulatory } \\
\text { system may delay SPS } \\
\text { deployment. } \\
\text { The cost of deeting regu- } \\
\text { lat lons may constrain } \\
\text { deployment withost } \\
\text { sufficlent lead :imes. }\end{array}$ & $\begin{array}{l}\text { International sorereignty } \\
\text { issues are unresolved. } \\
\text { The extent of potential } \\
\text { environmental impacts } \\
\text { is unknown. }\end{array}$ & $\begin{array}{l}\text { Develop an alternative } \\
\text { regulatory configuration } \\
\text { that ninimizes known } \\
\text { institutional problems. }\end{array}$ & $\begin{array}{l}\text { SPS has a unique international } \\
\text { issue (radio frequency alloca- } \\
\text { tion, orbital assignment, } \\
\text { and microwave health } \\
\text { standards). }\end{array}$ \\
\hline Fusion & & Dot addressed. & . & & $\cdot$ \\
\hline $\begin{array}{l}\text { Compara- } \\
\text { tive } \\
\text { Analysis }\end{array}$ & . & $\begin{array}{l}\text { The least mature techno- } \\
\text { logies (i.e., SPc, Fusion) } \\
\text { face more regtlatory } \\
\text { constraints ard fossible } \\
\text { cost increases than more } \\
\text { mature. technologies, since } \\
\text { a regulatory scenario is } \\
\text { not yet defined. }\end{array}$ & $\begin{array}{l}\text { The SPS has more insettled } \\
\text { regulatory issues than the } \\
\text { other energy systems. } \\
\text {. }\end{array}$ & $\begin{array}{l}\text { Assess regulatory effects } \\
\text { on the deployment schedule } \\
\text { of the scenario. }\end{array}$ & - \\
\hline
\end{tabular}




\section{A PRELIMINARY ASSESSMENT OF THE \\ SATELLITE POWER SYSTEM (SPS) \\ AND SIX OTHER ENERGY TECHNOLOGIES}

by

T. Wolsko, C. Brown, R. Cirillo, J. Gasper, L. Habegger, K. Hub, E. Levine, D. Newsom, M. Samsa, E. Tanzman; J. Vankuiken, and R. Whitfield

ABSTRACT

This report describes the comparative assessment portion of the Satellite Power System (SPS) Concept Development and Evaluation Program established by the Department of Energy and the National Aeronautics and Space Administration to generate information from which a rational decision could be made regarding the viability of the SPS. The objective of the comparative assessment is to develop an initial understanding of the SPS with respect to a limited set of energy alternatives. Six alternative technologies (conventional coal combustion; light water reactor; coal gasification/ combined cycle; 1 iquid-metal, fast-breeder reactor; terrestrial photovoltaic; and fusion) were compared to the SPS on the basis of available data on cost and performance, health and safety, environmental welfare, resource requirements, and economics. These comparisons are descriptive and do not culminate in any "bottom line" regarding the overall viability of the SPS.

\section{INTRODUCTION}

\subsection{BACKGROUND}

The SPS Concept Development and Evaluation Program (CDEP) was established by the Department of Energy and the National Aeronautics and Space Administration to generate information from which a rational decision could be made regarding the direction of the Satellite Power System (SPS) program after fiscal 1980. The Comparative Assessment program is one of four functional areas within the joint DOE/NASA-CDEP. The other CDEP functional areas are:

- Systems Definition: reference system design, alternative and advanced concept design, and critical supporting studies.

- Environmental Assessment: evaluation of human health and safety, ecological, atmospheric, and electromagnetic interference issues pertaining to microwave transmission, powerline transmission, transportation activities, construction, and operation of the SPS. 
- Societal Assessment: evaluation of international issues, institutional issues (e.g., utility interfacing), resource issues, and public outreach.

The results of these three activities are inputs to the comparative assessment process as well las to program assessments. These four areas form the basis for the CDEP assessment of the technical possibility, economic viability, and environmental and social acceptability of the SPS concept.

\subsection{OBJECTIVE AND APPROACH}

This report concerns the comparative assessment portion of the CDEP. The objective of the comparative assessment is to develop an initial understanding of the SPS with respect to a limited set of energy alternatives. This is conoiotent with the ovcrall CDEP objective' to determino whothor the SPS concept is sufficiently attractive (presenting no insurmountable barriers) to receive further research investment.

In all comparative assessments it is vital that the assumptions, uncertainties, and significant differences between the systems being compared be clearly. and objectively presented. Otherwise the comparison may prove unacceptable for meaningful decisions. The key assumptions made and ground rules followed in this report are:

1. The baseload electric generation technologies are projected to be on line in the year 2000, with an approximate availability date of 1990. Further, the R\&D base and the infrastructure are assumed to be in place when required.

2. All data are traceable to publicly available information.

3. Each technology is treated as an independent variable. For example, if coal costs go up or down, the costs of the other technologies are assumed not to change for the same reasons.

4. When no historical data or basic reports were available, the analysts specified conditions chosen and presented their rationale. In cases where the chosen conditions have favored or disfavored a technology, the analysts have stated the hias.

The SPS, fusion, and central-station solar photovoltaics technologies have received less engineering design and $R \& D$ attention than the other technologies examined in this assessment. Therefore, they are subject to larger uncertainty as well as greater optimism. Further, the 1 ife cycle costs of these three technologies are reduced by the second part of the first assumption, since the $R \& D$ and infrastructure costs are not addressed explicitly.

The third assumption tends to exaggerate cost overlap, but taking correlated characteristics into account was not feasible in this study. The choices made under the fourth assumption tend to favor the two solar technologies and fusion. 
The data derived under these assumptions was rather limited for some technologies (particularly for TPV and fusion), and in consequence some of the technologies were not compared in all issue categories, More complete comparisons will be included in the final assessment.

The intention is to compare SPS to each of the other six technologies, or to subsets of the six, or to all six technologies together. The limitations resulting from the assumptions preclude other comparisons. Within these assumptions and ground rules, the six energy technologies were selected, characterized to the extent allowed by the data, and documented. These data were normalized to unit bases, such as dollars per megawatt or environmental residuals per megawatt, and alternative futures were compared (i.e., possible technology mixes, supply and demand cases, and resultant environmental, resource, and cost uncertainties).

To achieve this objective, the comparative assessment has been divided into four parts:

1. Energy alternatives characterization: terrestrial alternatives are selected, and their cost, performance, and environmental and societal attributes are specified for use in the comparison with the SPS in the post-2000 era.

2. Methods: the framework for comparisons is established.

3. Evaluation: the SPS is compared with alternative systems in terms of key issues such as 1 ife-cycle cost and environmental impacts.

4. Management and integration: the results of the assessments are assembled and integrated into a consistent comparative assessment.

Data on alternative technologies are sought from previous research and from other comparisons. Data on the SPS are taken from other parts of the program. In the comparative assessment, traceable data are gathered, evaluated, and normalized to some consistent power or energy level and then synthesized into a format convenienl for cumparison.

This preliminary assessment is an attempt at a comparative perspective on the SPS and alternative energy systems in the post-2000 era. The initial assessment was limited to large central-station baseload plants. The group of central-station technologies was limited to:

- improved conventional coal systems

- pressurized water reactor (PWR)

- coal gasification/combined cycle (CG/CC)

- liquid-metal, fast-breeder reactor (LMFBR)

- central station, terrestrial photovoltaic (TPV)

- satellite power system (SPS)

- fusion 
Described briefly in this report and in a companion report is a six-step methodology. This preliminary assessment took only the first four steps and has culminated in what is referred to as a preliminary side-by-side assessment, because the data are expected to be improved in the subsequent comparative assessment. The side-by-side assessment. reported here is a normalized comparison (i.e., per unit of energy output, such as per megawattyear) based on assumptions about economic conditions in the beginning of the 21 st century. The subsequent assessment will improve on this one by updating the comparative data base for improved side-by-side comparison and adding an alternative-futures comparison. This alternative-futures comparison will define plausible economic and energy futures and make comparisons based on the energy and economic climate pertinent to these futures.

Reported in this document are (1) a brief descripelon of the cumparative methodology, (2) brief characterizations of the alternative technologies, (3) side-by-side comparisons, by issue, and (4) a discussion of the status and future directions of the assessment. 


\section{ASSESSMENT FRAMEWORK}

\subsection{OVERVIEW}

This section describes a framework for comparing the SPS with various projected alternative energy sources on the basis of technical possibility, economic viability, and social and environmental acceptability. A more detailed description of the approach and methods used in the assessment is contained in the methodology report for the comparative assessment.1

The methodology for the analysis in the comparative assessment is composed of the following steps (Fig. 2.1):

1. Comparative issues selection.

2. Energy alternatives selection. Many possible issues and alternatives are examined, and these selections provide an initial focus for the remaining steps in the coumparative assessment.

3. Energy system characterization. The energy system characterization provides reference data on technology cost and performance, resource use, and environmental residuals.

4. Side-by-side analysis of energy systems. Side-by-side analys is normalizes the energy output from each system to allow comparison of alternative technology impacts.

5. Alternative futures analysis. The alternative futures analysis incorporates the results of the impact analysis into future energy supply/demand and state-of-the-world scenarios that are not forecasts but are designed to examine specific issues and potential problems over a range of possible futures.

6. Development and application of integration/aggregation techniques. The development of techniques for integrating and aggregating the large amounts of daca and information provided by the analys is will aid the decision maker in formulating SPS program recommendations.

Only the first four steps have been done in this preliminary side-by-side comparative assessment. The following sections describe each step of the comparative assessment framework in more detail.

\subsection{COMPARATIVE ISSUES}

The selection of issues for the comparative assessment must be guided by the idea that not only should the issues structure be general enough to accommodate different impacts that result from the alternative technologies, but it should also be specific enough 80 that comparisons between technologies are feasible and commensurate. 


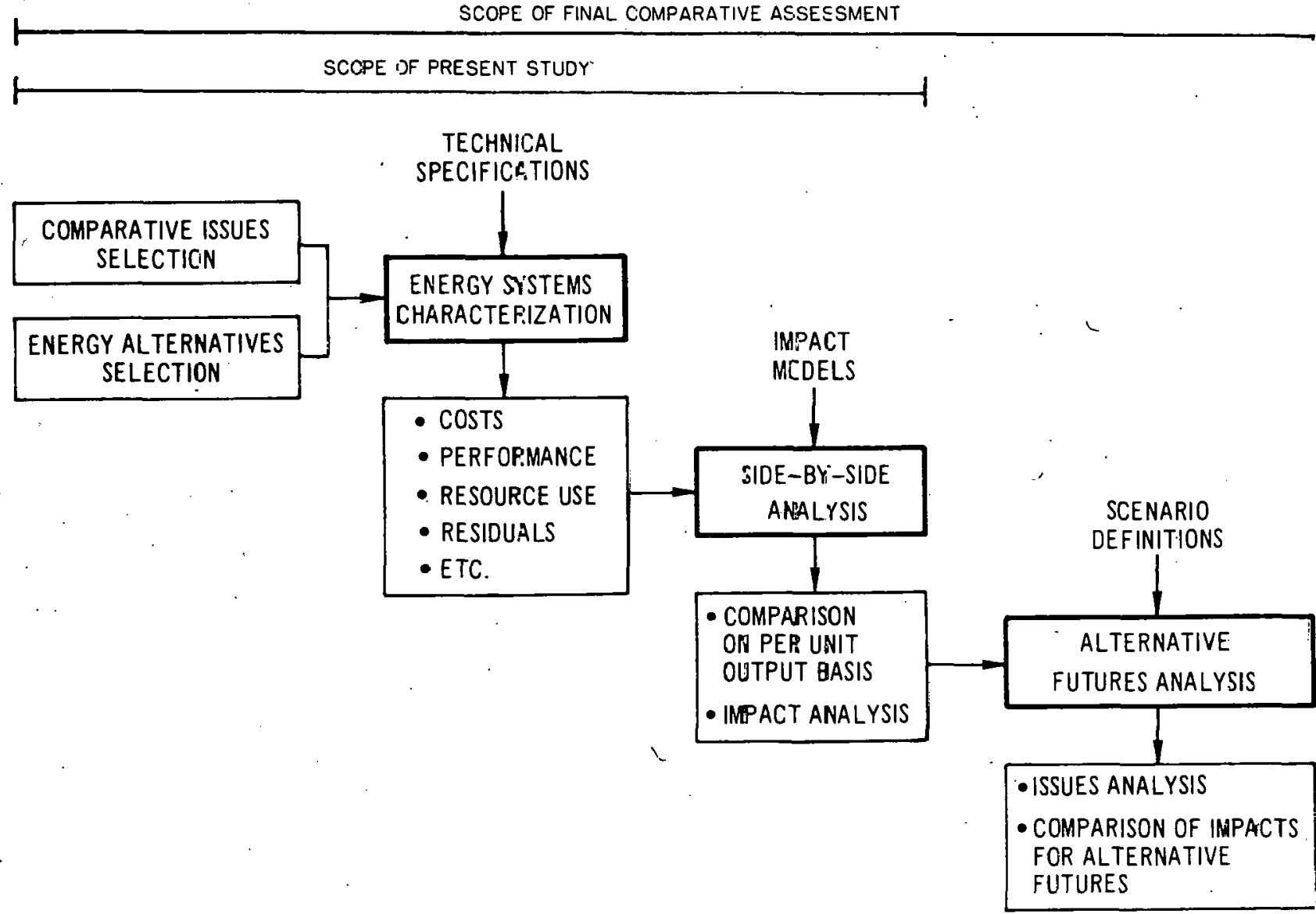

TECHNICAL

ENERGY STSTEMS

CHARACTEFIIZATION

- COSTS

resouRCE USE

- RESIDUALS

- ETC.

FUTURES

LTERNATIVE

INTEGRATION/AGGREGATION ME THODOLOGIES

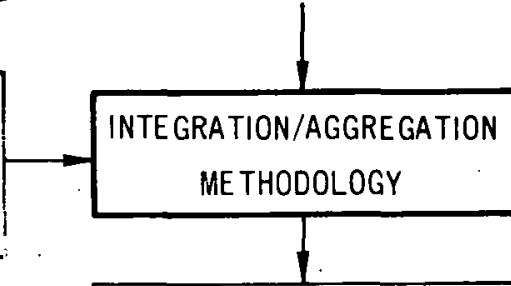

- FRAMEWORK TO ASSIST DECISION MAKER'S RECOMMENDATION

- STRUCTURE TO HANDLE

LARGE AMOUNT OF

INFORMATION ON CONSISTENT BASIS

Fig. 2.1. Analysis Sequence for Comparative Assessnez: 
The classification system for the preliminary comparative assessment is shown in Fig. 2.2. The five major issue categories are cost and performance, environmental, economic and societal, resource, and institutional.

In the cost and performance category, the life-cycle cost and system performance are compared. Life-cycle cost includes development, construction, operation, maintenance, and decommissioning. Reliability is an example of an important system performance issue. The costs being compared are projected, and it is important to specify the uncertainty in these projections so that conclusions can be drawn in perspective.

Environmental issues are divided into two subcategories: health and safety issues and welfare issues. Health and safety is subdivided into public and occupational issues. In this context, health refers to chronic impacts (e.g., respiratory illness), whereas safety refers to the effects of accidents such as launch malfunctions, spills, and unexpected releases of hazardous pollutants. Welfare impacts are those that result from disruptions of the physical environment, such as damage to buildings from air pollution, degradation of radio-frequency communication due to microwave interference, and changes in land value because of deployment of an energy technology.

The economic and societal category is divided into two parts: macroeconomic and socioeconomic. The macroeconomic issues deal with national and regional macroeconomic impacts (e.g., trade, GNP, capital availability, and employment). Socioeconomic issues concern the monetary impact and social stresses on the localities where power systems are sited.

Institutional comparisons deal with the effects of existing and potential institutions on the deployment of a technology (regulatory impacts). International, institutional issues are also addressed. The resource category includes five subcategories: land, labor, materials, energy, and water. Here, key concerns include resource limits, production limits, dependence on foreign resources, and need for new skilled labor.

\subsection{ENERGY ALTERNATIVES SELECTION}

The technologies initially considered for comparison with the SPS are listed in Table 2.1 and include seven fossil options, five nuclear technologies, and five solar technologies. The list was narrowed to six technologies according to the following criteria:

- The list must be kept to a minimum, but each major technology should be represented.

- Energy output must be in the form of electricity.

- Commercial availability should be possible after the year 2000 .

- The technology should have the capability for baseload operation.

- Fuel must be available for many years (e.g., 2000-2050).

- Design information should be available. 


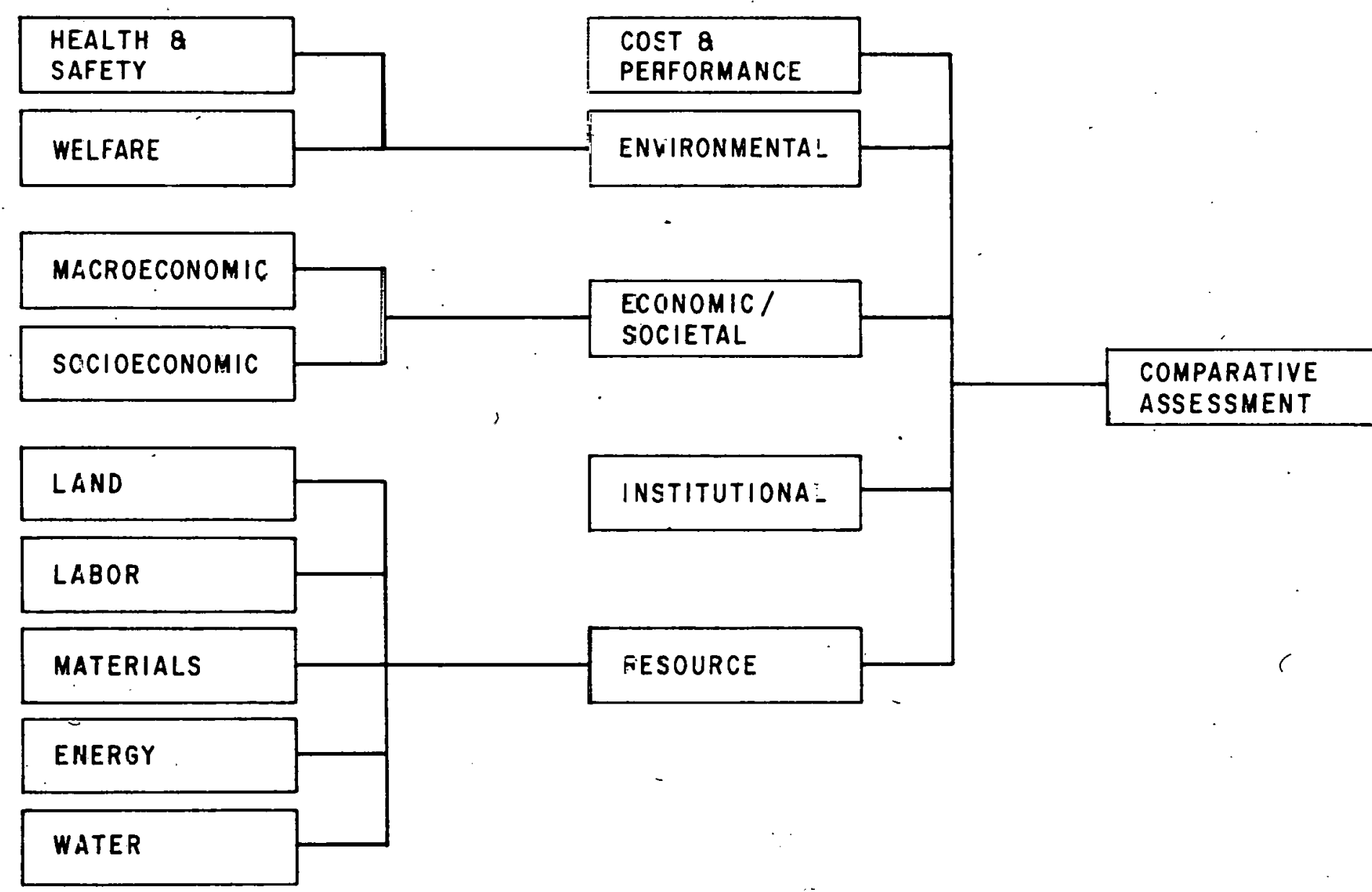


Table 2.1. Candidate Alternative Technologies

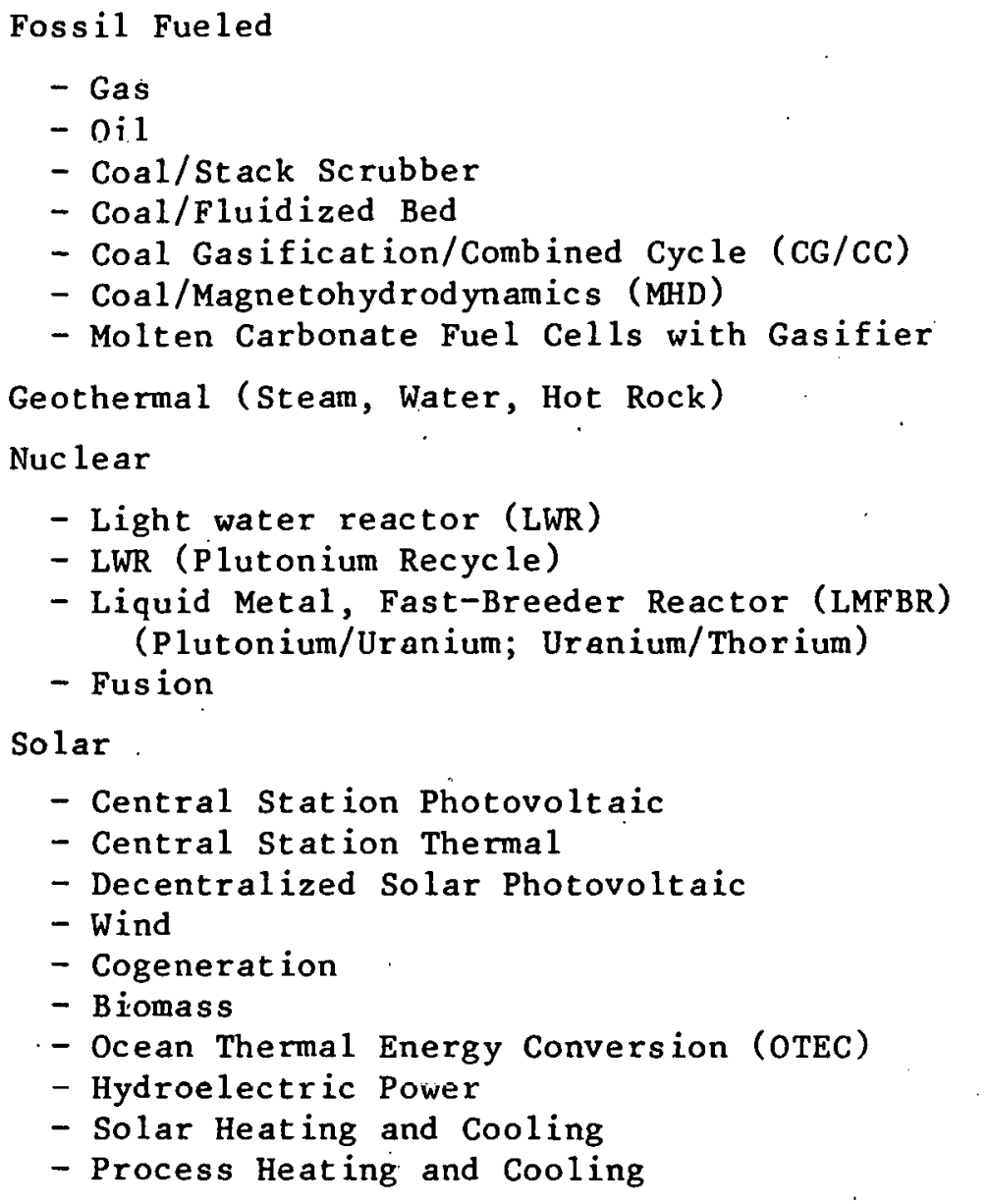

The energy alternatives selected were coal with stack scrubber, coal gasification/combined cycle, the light water reactor, the liquid-metal breeder reactor, tusion, and the solar photovoltaic central station. Missing from this 1 ist are solar technologies utilizing wind and biomass and decentralized solar (e.g., space heating and cooling, process heating and cooling, water heating; and decentralized photovoltaic systems). Since this is a preliminary side-by-side comparative assessment, there will be opportunities later to include these alternatives. As stated previously, this first attempt was 1 imited to central-station baseload technologies.

\subsection{ENE'KGY SYSTEM CHARACTERIZATION}

Following the selection of energy alternatives and the preliminary selection of comparative issues, the reference energy systems were defined and described, and data on cost, performance, and environmental impact were collected from published sources for issue comparisons. 
The ground rules for this data collection included the following:

- Characterizations should use readily available information.

- Characterizations should be performed and documented by persons who are knowledgeable about alternative technologies and DOE programs.

- Each technology characterization should be internally consistent.

- The set of characteristics should display overall consistency and facilitate comparisons with the SPS concept.

- There should be enough information to allow adequate evaluation of issues (failing this criterion, a candidate technology may have to be dropped from consideration at a later date).

\subsection{SIDE-BY-SIDE ANALYSIS OF ENERGY SYSTEMS}

The objective of the side-by-side analysis is an initial comparison of the alternatives on the basis of isolated units, using a consistent set of ground rules for all units and normalizing all units to the same power level. This is the initial analytical step of the comparative assessment, and it consists of a listing of information (some detailed, some summary) for each of the energy systems. Information categories cover the technical, economic, environmental, and societal issues mentioned earlier.

Two important functions of the side-by-side analysis are: (1) providing the decision maker and analyst with a normalized comparison; and (2) functioning as an intermediate step between the technology characterizations and the alternative futures analysis.

\subsection{ALTERNATIVE FUTURES ANALYSES AND INTEGRATION/AGGREGATION TECHNIQUES}

Alternatives futures analyses and the application of integration/ aggregation techniques would be the next two steps in the methodology for the comparative assessment. However, these analyses were not carried out in the preliminary assessment, but descriptions of these techniques $c$ an be found in a companion document -- A Methodology for the Comparative Assessment of the SPS and Alternative Technologies. 1 


\section{CHARACTERIZATIONS OF THE SPS AND ALTERNATIVE TECHNOLOGIES}

This section contains brief descriptions of each of the technologies considered. More detailed technology characterizations are contained in the SPS CDEP Reference System Report ${ }^{2}$ and in the alternative technology characterization reports. 3,4 The objective of the preliminary technology characterizations was to collect and develop a consistent and traceable set of characterization parameters for the SPS and other possible post-2000 baseload systems. The characterizations represent "first-order" characteristics that define systems in sufficient detail for the cost and environmental analyses:

\subsection{ALTERNATIVE TECHNOLOGY SELECTION}

The preliminary 1 ist of 34 technologies (Table 3.1 ) was initially screened according to two sets of criteria. The list was reduced to a subset of systems that were then further screened by more restrictive criteria to a final subset of alternatives. Decentralized technologies were excluded from consideration for the preliminary assessment, since the focus was on baseload technologies. Decentralized technologies will be considered in the final comparative assessment. A more detailed description of the technology screening and selection process, is presented in another report. 7

Initial screening was both qualitative and quantitative. The qualitative screening procedure included the following criteria for selection of an initial and representative subset of candidate electrical power generation systems :

A. The initial set should include improved conventional systems (e.g., coal and LWR systems).

B. It should represent the following classes of advanced systems :

1. Advanced coal combustion and synfuels,

2. Solar,

3. Fissinn,

4. Fusion, and

5. Geothermal

C. It should include the principal energy systems most suitable for large, central-station baseload generation within each class of inexhaustible energy sources.

D. It should reflect the consensus about which candidates are most likely to be viable in the year 2000 .

A three-person team of qualified energy technology researchers was asked to judge the candidate technologies according to the 1 isted criteria, and their choices of the most viable candidate technologies for the year 2000 constituted the qualitative screening selections.

The quantitative screening technique was more rigorous in that it explicitly considered five major technology factors and numerous subfactors (Table 3.2). In this screening process, technology experts were asked to 
Table 3.1. Technologies Considered in Initial Screening

\begin{tabular}{|c|c|c|}
\hline Energy Source & Conventional Systems & New Systems \\
\hline \multicolumn{3}{|c|}{ Exhaustible Resource Technologies } \\
\hline Coal & $\begin{array}{l}\text { Coal-steam plants with flue- } \\
\text { gas desulfurization }\end{array}$ & $\begin{array}{l}\text { - Coal-steam plants with im- } \\
\text { proved environmental controls } \\
\text { - Atmospheric fluidized-bed } \\
\text { combustion (AFBC) } \\
\text { - Pressurized fluidized-bed } \\
\text { combustion (PFBC) } \\
\text { - Low-Btu gasifier/open cycle } \\
\text { gas turbine, combined cycle } \\
\text { - Closed cycle gas turbine } \\
\text { - Motal vapor topping cycle } \\
\text { - Open cycle magnetohydrodynamics } \\
\text { (MHD) } \\
\text { - Closed cycle magnetohydrodynamics } \\
\text { - Molten carbonate fuel cell with } \\
\text { gasifier (MCFC) } \\
\text { - Synthetic fuels for advanced } \\
\text { power cycles }\end{array}$ \\
\hline Fission & $\begin{array}{l}\text { Light water reactors with } \\
\text { once-through fuel cycle }\end{array}$ & $\begin{array}{l}\text { - Light water reactors (LWR) with } \\
\text { improved fuel utilization ef- } \\
\text { ficiency } \\
\text { - Light water reactors with mixed } \\
\text { oxide fuels } \\
\text { lligh tempcraturc gac-cooled } \\
\text { reactors } \\
\text { - Advanced high temperature } \\
\text { reactors }\end{array}$ \\
\hline Geothermal & Dry steam & $\begin{array}{l}\text { - Liquid-dominated hydrothermal } \\
\text { - Geopressure }\end{array}$ \\
\hline \multicolumn{3}{|l|}{ Renewable or } \\
\hline Solar & $\begin{array}{l}\text { Hydroelectric } \\
\text { Wood-fired steam }\end{array}$ & $\begin{array}{l}\text { - Solar thermal electric with } \\
\text { storage } \\
\text { - Snlar phntovoltaic with storage } \\
\text { - Ocean thermal energy conversion } \\
\text { - Wind energy conversion with } \\
\text { storage } \\
\text { - Biomass fueled (other chan wood- } \\
\text { fired steam) }\end{array}$ \\
\hline Fission & . & $\begin{array}{l}\text { - Liquid-metal, fast-breeder } \\
\text { reactor (LMFBR) } \\
\text { - Gas-cooled, fast-breeder reactor } \\
\text { - Light water breeder reactor } \\
\text { - Electronuclear breeder } \\
\text { - Fusion-fission systems }\end{array}$ \\
\hline Fusion & & $\begin{array}{l}\text { - Magnetic confinement fusion } \\
\text { - Inertial confinement fusion }\end{array}$ \\
\hline Geothermal & & - Hot dry rock (HDR) \\
\hline
\end{tabular}


Table 3.2. Quantitative Screening of Energy Systems

\begin{tabular}{ll}
\hline \multicolumn{1}{c}{ Factors } & \multicolumn{1}{c}{ Subfactors } \\
\hline Technology Availability & Technology Feasibility \\
& Fuel or Energy Resource Availability \\
& Regional Limitations \\
& Status of Development \\
& RD\&D Costs \\
Economic Attractlveness & Capital and O\&M Costs \\
& Fuel Costs \\
& Plant Availability and Reliability \\
& Utility Compatibility \\
& Air and Water Pollutants \\
Environmental Impacts & Land Use or Disturbance \\
& Public Health and Safety \\
& Reversible vs Irreversible Impacts \\
& Energy, Materials \\
& Land, Water \\
Critical Resource Requirements & Capital, Manpower \\
& Economic \\
& Industrial Infrastructure \\
Socioeconomic Impacts & International : \\
&
\end{tabular}

assign values ranging from 1 (most restrictive) to 5 (least restrictive) to each of the five factors for each technology in the list of 34 options. Each of the factors was weighted equally, and the process was applied separately to technological options in each major group or energy source (e.g, coal, fission, fusion, and geothermal). Within each group, those technologies receiving the highest overall aggregate ranking were recommended. The qualitative and quantitative recommendations of systems options are shown in Table 3.3 . The following criteria were used in the final alternative technology selection:

1. Technical data are available in sufficient detall to allow adequate technical characterization and comparison.

2. Cost data are defined and available in sufficient detail to allow adequate cost characterization and comparison.

3. Projected availability for commerclal application of the technologies is around the year 2000.

4. The final selections should include improved current baseload technologies.

5. The final selections should include representative advanced terhnologies currently being engineered. 
6. The final selections should include alternative (non-space) applications of photovoltaic solar energy technology.

7. The final selections should include one technology alternative that shows potential as a long-term energy source in the post-2000 era and which receives heavy development funding.

Table 3.4 is the final decision matrix for selection of six major baseload alternatives. The matrix shows how each of the ten technologies ranked with regard to the seven final selection criteria. However, the dominant six technologies cannot be readily identified from the matrix.

The light water reactor (LWR) and coal technologies best satisfy the applicable criteria and thus were included in the final list of technologies to be compared with the SPS. Only one technology, terrestrial photovoltaics (TPV), meets the special criterion (No. 6) established to provide for a direct comparison of photovoltaics in space and terrestrial applications.

Three of the remaining seven technologies are advanced coal-based systems, molten carbonate fuel cell (MCFC), coal gasification/combined cycle (CG/CC), and magnetohydrodynamics (MHD). The combined cycle system had the highest ranking of the three and thus was selected for inclusion in the comparative assessment as a representative advanced coal system.

of the four remaining technologies, the liquid metal fast breeder reactor (LMFBR) has the highest ranking: Although controversial, this technology has received worldwide backing and was thus included in the comparative assessment.

The final three technologies, (solar thermal, hot dry rock geothermal, and fusion) represent extensive sources of energy. Fusion is heavily funded by DOE and apparently represents a technology of high scientific interest and potential. Therefore, it was selected to fill a position as a baseload alternative, even though possible commercial application may not be feasible until one to several decades after the year 2000.7

Table 3.3. Initial Screening of Electric Generation Technologies

\begin{tabular}{|c|c|c|}
\hline $\begin{array}{l}\text { Qualitative } \\
\text { Boreellug } \\
\text { Selertions }\end{array}$ & $\begin{array}{l}\text { Quantitative } \\
\text { Screenlng } \\
\text { Sflertions }\end{array}$ & Electric Generation System \\
\hline $\begin{array}{l}\mathrm{X} \\
\mathrm{X} \\
\mathrm{X} \\
\mathrm{X} \\
\mathrm{X} \\
\mathrm{X} \\
\mathrm{X} \\
\mathrm{X} \\
\mathrm{X} \\
\mathrm{X}\end{array}$ & $\begin{array}{l}X \\
X \\
X \\
X \\
X \\
X \\
X \\
X\end{array}$ & $\begin{array}{l}\text { LWR with Improved Fuel Utilization } \\
\text { Coal, with Improved Environmental Controls } \\
\text { Molten Carbonate Fuel Cell with Gasifier } \\
\text { Combined Cycle with Low-Bru Gasifier } \\
\text { Solar Photovoltaic with Storage } \\
\text { Solar Thermal with Storage } \\
\text { Liquid Metal, Fast-Breeder Reactor } \\
\text { Magnetic Confinement Fusion } \\
\text { Open Cycle MHD } \\
\text { Hot Dry Rock Geothermal }\end{array}$ \\
\hline
\end{tabular}


Table 3.4. Final Technology Selection Decision Matrix

1.

\begin{tabular}{|c|c|c|c|c|c|c|c|}
\hline \multirow[b]{2}{*}{ Technology } & \multicolumn{7}{|c|}{ Selection Criteria } \\
\hline & 1 & 2 & 3 & 4 & 5 & 6 & 7 \\
\hline Light Water Reactor (LWR)a & VH & VH & $\mathrm{Y}$ & $\mathrm{Y}$ & - & - & 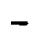 \\
\hline Coala & VH & VH & Y & $\mathbf{Y}$ & - & - & - \\
\hline Molten Carbonate Fuel Cell (MCFC)a & A & A & $\dot{\mathbf{P}}$ & - & $\mathbf{Y}$ & - & - \\
\hline Coal Gasification/Combined Cycle (CG/CC)a & H & $\mathbf{H}$ & $\mathbf{Y}$ & - & Y & - & - \\
\hline Terrestrial Photovoltaic (TPV)a & A & $\mathbf{A}$ & $\mathbf{P}$ & - & - & $\mathrm{Y}$ & . \\
\hline Solar Thermal. & $\mathbf{A}$. & $\mathbf{A}$ & $\mathbf{P}$ & - & - & - & . \\
\hline Liquid Metal, Fast-Breeder Reactor (LMFBR)a & $\mathrm{H}$ & $\mathrm{H}$ & $\mathbf{P}$ & - & $\mathrm{Y}$ & - & $\mathrm{Y}$ \\
\hline Fusion ${ }^{a}$ & L & $\mathbf{L}$ & $\mathbf{N}$ & - & - & - & $\mathbf{Y}$ \\
\hline Magnetohydrodynamics (MHD) & $\mathrm{A}$ & A & $\mathbf{P}$ & - & $\mathrm{Y}$ & - & - \\
\hline Hot Dry Rock (HDR) Geothermal & $\mathrm{L}$ & $\mathrm{L}$ & $\mathbf{N}$ & - & - & - & - \\
\hline
\end{tabular}

$\begin{array}{llll}\text { Key: } & \text { VH: } & \text { Very High } & \text { Y: Yes } \\ \text { H: High } & \text { P: Possible } \\ \text { A: Adequate } & \text { N: No } \\ \text { L: } & \text { Low } & -: \text { Not Applicable }\end{array}$

aselected for characterization and comparative assessment.

\subsection{TECHNICAL DESCRIPTION OF ALTERNATIVE GENERATION SYSTEMS}

The characteristics of each of the alternative generation systems have been derived primarily through a synthesis of data and information obtained from available technical literature. The best self-contained system characterizations available in single documents were chosen as primary data sources. Where deficiencies were noted, available supplemental material was obtained or input from reviewers was solicited.

In most cases, the available data are for nominal systems that differ in some respects from the reference alternatives chosen for comparison. Usually, these differences are a result of varying assumptions about system generating capacity, cooling type, or, in some cases, even the site or fuel characteristics. Thus, in some cases, the reference characterizations required engineering judgment to adjust data to the system capacities and basic assumptions being used. The subsequent analyses are generally not sensitive to small variations in the system parameters derived in this fashion. How ever, the analys is is broad enough to allow reasonable conclusions to be drawn.

The parameters addressed in the system characterizations include those that relate to the physical system design and operating factors, capital and operating costs, reliability and availability, resource requirements, and environmental residuals. Studies by $\mathrm{TRW}^{3}$ and United Engineers and Constructors ${ }^{4}$ provide the basis for the non-sPS technical, environmental; and cost characterizations summarized in the following sections of this chapter. 


\subsubsection{Satellite Power System}

The satellite power system characterization is based on data available in the SPS CDEP Reference System Report ${ }^{2}$ supplemented by additional studies performed for NASA by Boeing 5 and Rockwell.6 The satellite power system consists of three basic elements: the first two, in geosynchronous orbit at $36,000 \mathrm{~km}$, are the solar collector, which receives energy from the sun and converts it to electrical energy, and a microwave antenna, which transmits that energy to the third element, an earth-based rectifying antenna (rectenna). The reference system is sized for $5 \mathrm{GW}$ of DC power output to a conventional utility grid. The satellite has one end-mounted antenna, as illustrated in Fig. 3.1.

The satellite consists of a planar solar array structure of graphite composite material. Two conversion options (Fig. 3.2) are presently being considered: one is the use of single-crystal gallium aluminum arsenide (GaAlAs) solar cells with a concentration ratio of 2 ; the other is the use of single-crystal silicon $(\mathrm{Si})$ solar cells with no concentration.

The size of the solar array is dictated primarily by the efficiency chain of the various elements in the system. Figure 3.3 shows the end-to-end efficiency chain for the GaAlAs and silicon cell options. The satellite is designed to provide $5 \mathrm{GW}$ of DC power to the utility busbar, and with an overall efficiency of approximately.7\%, it is necessary to size the solar arrays so that approximately $70 \mathrm{GW}$ of solar energy will be intercepted. The efficiency assumed is the minimum efficiency, including the worstcase summer solstice factor $(0.9675)$, the seasonal variation $(0.91)$, and the end-of-life (30-year) solar cell efficiency (assuming annealing in the silicon case). For the GaAlAs case, the end-of-life (30-year) concentrator reflectivity is 0.83 . Since only half of the intercepted solar energy is reflected by the concentrators, the equivalent 1 ifetime average efficiency is 0.915 .

The GaAlas uption is a five-trughl configuxation with a solar blanket area of $26.52 \mathrm{~km}^{2}$, a reflector area of $53.04 \mathrm{~km}^{2}$, and an overall planform area of $55.13 \mathrm{~km}^{2}$. The silicon option has the solar blanket with no concentration, resulting in a blanket area of $52.34 \mathrm{~km}^{2}$ and a planform area of $54.08 \mathrm{~km}^{2}$. Table 3.5 lists the cell and planform power characteristics for each cell type.

The end-mounted microwave antenna is a phased-array transmitter of $1-\mathrm{km}$ diameter. The phase control system utilizes an active, retrodirective array with a pilot beam reference for phase conjugation. Klystrons are used as the baseline power amplifier with slotted waveguides as the radiating element. The ground rectenna has subarray panels with an active element area of 78.5 $\mathrm{km}^{2}$.

The construction of the satellite in geosynchronous orbit (GEO) is estimated to extend over a period of $s$ ix months. The initial estimates of construction crew size are 555 for the silicon option [480 in GEO and 75 in low earth orbit (LEO)] and 715 for the GaAlAs option (680 in GEO and 35 in LEO). 


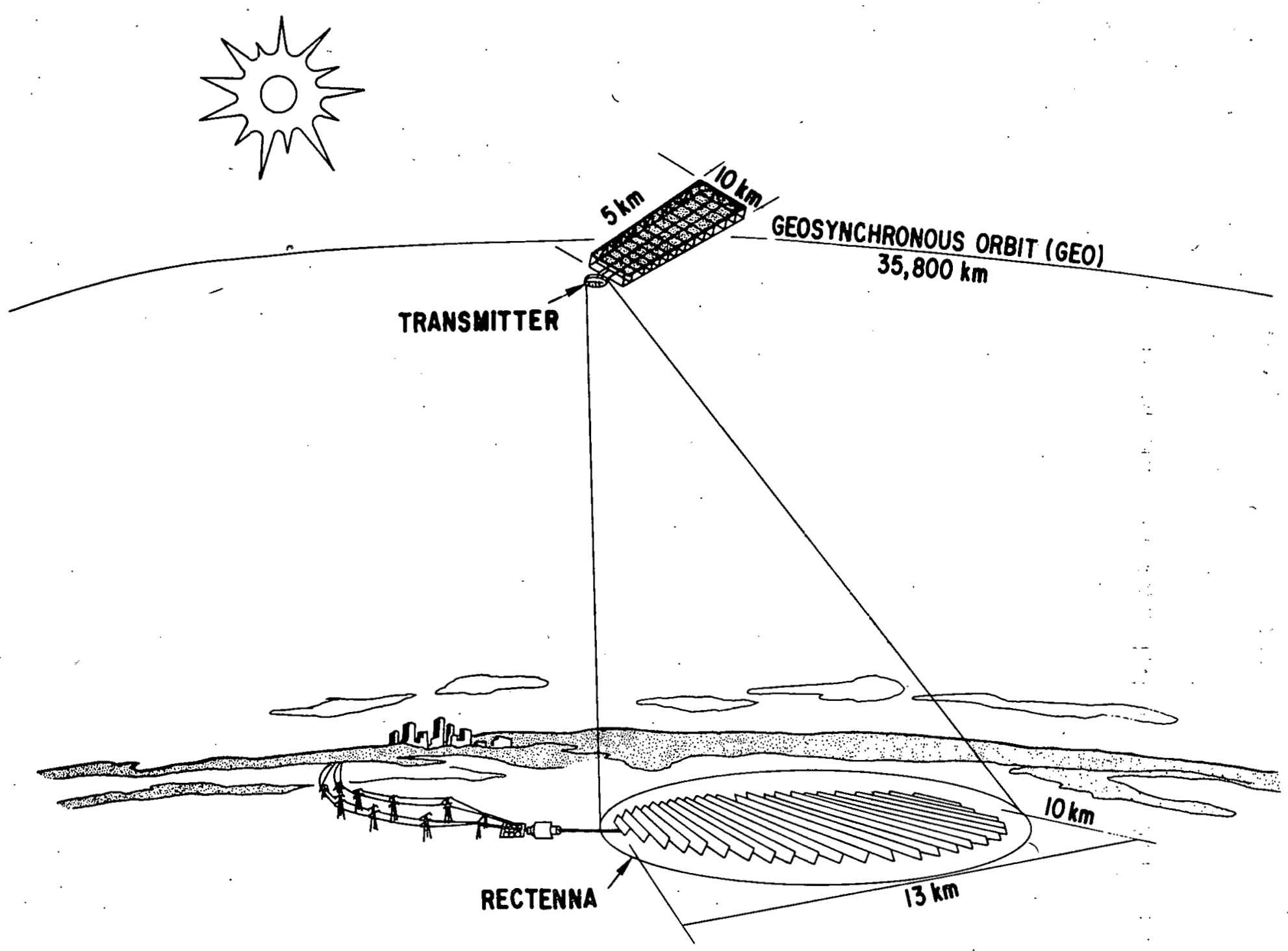

Fig. 3.1. Satellite Power System Concept (Source: Ref. 2) 
SILICON CR $=1$

BLANKET AREA $=52.34 \mathrm{~km}^{2}$

PLANFORM AREA $=54.08 \mathrm{~km}^{2}$
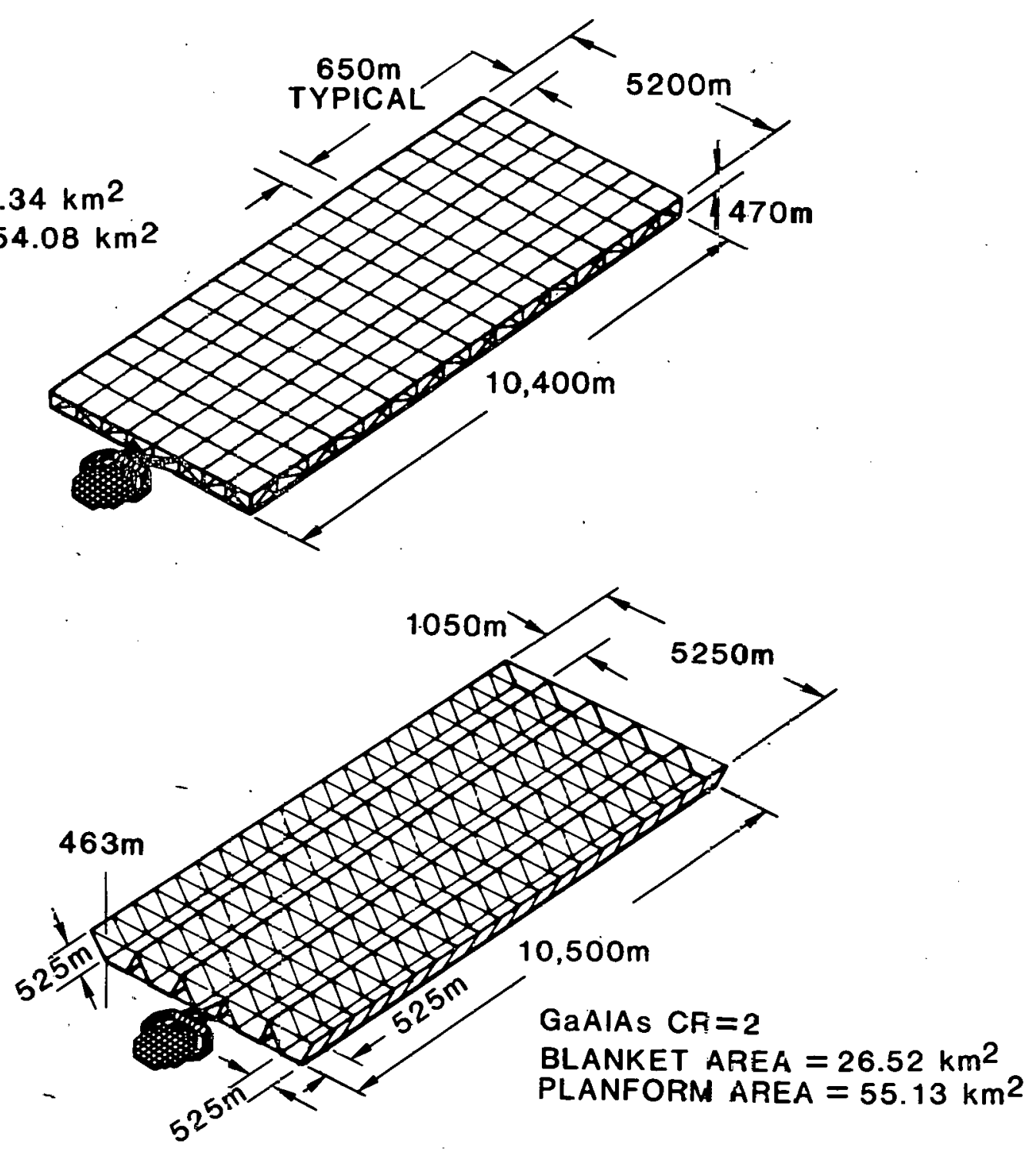

Fig. 3.2. SPS Satellite Configurations (Source: Ref. 2) 

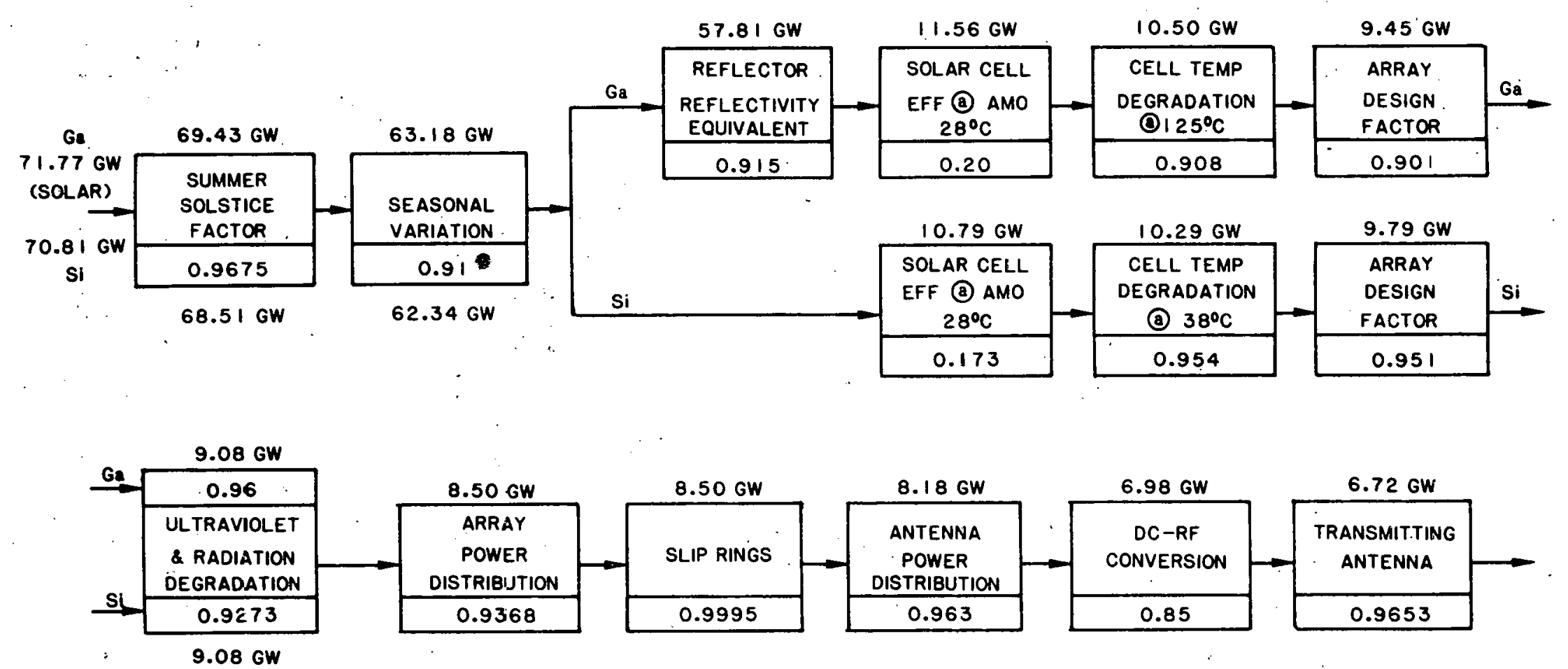

$6.72 \mathrm{GW}$
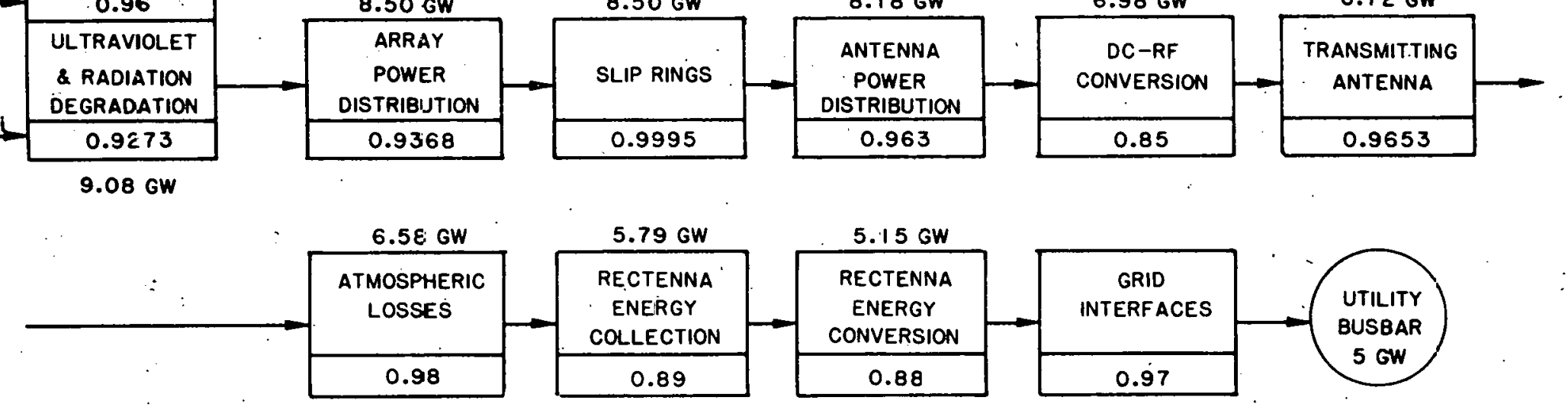

$5.15 \mathrm{GW}$

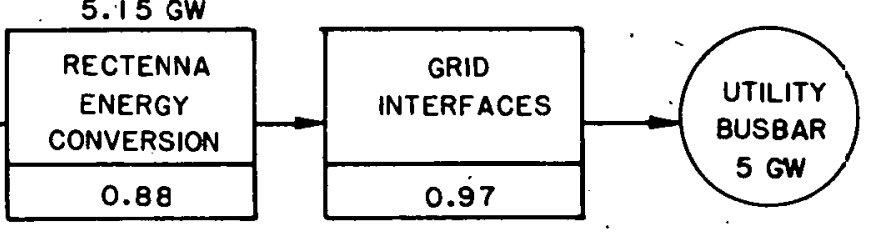

OVERALL EFFICIENCY $=6.97 . \% \mathrm{Ga}$

$7.06 \% \mathrm{si}$

MPTS EFFICIENCY $=63.0 \%$

Fig. 3.3. SPS Efficiency Chain, * GaAlAs $(C R=2)$ and $S i(C R=1)$

$$
\text { (Source: Ref. 2) }
$$

*Individual efficiencies are approximate and may be expected to change with additional analysis. 
Table 3.5. SPS Cell and Planform Power Characteristics

\begin{tabular}{lcc}
\hline \multicolumn{1}{c}{ Cell Type } & GaAlAs & Silicon \\
\hline Concentration ratio & 2 & 1 \\
Solar power available & $1,353 \mathrm{~W} / \mathrm{m}^{2}$ & $1,353 \mathrm{~W} / \mathrm{m}^{2}$ \\
Solar power on cell at maximum off-sun pointing & $2,414 \mathrm{~W} / \mathrm{m}^{2}$ & $1,190 \mathrm{~W} / \mathrm{m}^{2}$ \\
Cell conversion efficiency at $28^{\circ} \mathrm{C}$ AMO (in vacuum) & $20 \%$ & $17.33 \%$ \\
Blanket power output & $380 \mathrm{~W} / \mathrm{m}^{2}$ & $186 \mathrm{~W} / \mathrm{m}^{2}$ \\
Beginning of life & $370 \mathrm{~W} / \mathrm{m}^{2}$ & $149 \mathrm{~W} / \mathrm{m}^{2}$ \\
End of life & $183 \mathrm{~W} / \mathrm{m}^{2}$ & $186 \mathrm{~W} / \mathrm{m}^{2}$ \\
Planform power output & $171 \mathrm{~W} / \mathrm{m}^{2}$ & $149 \mathrm{~W} / \mathrm{m}^{2}$ \\
Beginning of life & &
\end{tabular}

Source: Ref. 2 .

The transportation system assumed for the NASA contractor reference system consists of four major components: the heavy-lift launch vehicle (HLLV), the cargo orbit transfer vehicle (COTV), the personnel launch vehicle (PLV), and the personnel orbit transfer vehicle (POTV). The HLLV is a twostage, vertical launch, winged, horizontal landing, reusable vehicle with a 424-metric-ton payload to low earth orbit. The Kennedy Space Center was chosen as the reference earth launch site. The COTV is an independent, reusable, electric engine-powered vehicle, which transports cargo from the HLLV delivery site in low earth orbit to the geosynchronous earth orbit. For the GaAlAs option, the COTV is powered by GaAlAs solar cells, whereas a silicon solar cell power supply is assumed for the silicon option.

Personnel for the orbital construction and support functions are transported to LEO by the PLV, which is a modified space shuttle orbiter with a passenger module. The POTV, a two-stage, reusable, chemical-fuel vehicle, is used to transfer personnel from LEO to GEO and vice versa. Additionally, a LEO operations base would be constructed and used for tempurary sturage of supplies and propellant.

Power conversion equipment converts the direct current (DC) power from the collectors into high density microwave ( $R F$ ) power; the microwave antenna transmits it to the ground-based rectifying antenna, called the rectenna. The microwave antenna is a phased-array transmitter of $1-\mathrm{km}$ diameter and contains 7,220 subarrays or power modules. The antenna transmits $6.85 \mathrm{GW}$ of power at $2.45 \mathrm{GHz}$.

The subarrays are arranged to provide a 10-decibel Gaussian power distribution across the array surface. The power density varies from 22.14 $\mathrm{kW} / \mathrm{m}^{2}$ at the center module to $2.45 \mathrm{~kW} / \mathrm{m}^{2}$ at the outer edge. At the earth's surface, the power is $23 \mathrm{~mW} / \mathrm{cm}^{2}$ at the rectenna center and $0.08 \mathrm{~mW} / \mathrm{cm}^{2}$ in the first sidelobe. 
Each subarray covers $108 \mathrm{~m}^{2}$, and contains from. 4 to 50 klystrons, depending on the power output of the subarray. Each klystron converts DC to $70 \mathrm{~kW}$ of $\mathrm{RF}$. An alternative concept described in the SPS CDEP Reference System Report, would use a $50 \mathrm{~kW}$ klystron tube that would result in the use of 6. to 50 tubes per subarray (Ref. 2, p. 30). The subarray radiates power through slotted waveguides on the surface. Phasing electronics in each subarray process a beam-phasing signal from the ground and focus the microwave beam. Waste heat is dissipated by radiation. The subarray also includes power distribution and conditioning equipment, waveguides, amplifiers, and frequency-control electronics.

The rectenna consists of a dipole network and diode rectifiers, which receive and rectify the microwave power, a power distribution and conditioning system, which collects and delivers the rectified DC power to the utility interface; and the structure that provides support to the dipole rectenna panels and components of the distribution system. The support structure also provides a ground plane for the microwave power.

At $35^{\circ}$ latitude, the rectenna area of $10 \mathrm{~km}$ by $13 \mathrm{~km}$ contains 814 rows of rectenna panels tilted $40^{\circ}$ to the horizontal, providing an active intercept area of $78.5 \mathrm{~km}^{2}$. A total of 436,805 panels will be assembled on site and erected. In order to minimize electrical wiring from the rectenna panel area, two electrical switchyards will be employed, each with its own converter and relay building. Total area of the rectenna site, including auxiliary buildings and the buffer zone, has been estimated to be an elliptical area $13 \mathrm{~km}$ by. $17 \mathrm{~km}$, or $174 \mathrm{~km}^{2} .8$

The configuration of the ground-based rectenna, which receives and rectifies the downlink power beam, has half-wave dipoles feeding Schottky barrier diodes. Two-stage, low-pass filters between the dipoles and diodes suppress harmonic generation and provide impedance matching. The rectenna is a series of serrated panels perpendicular to the incident beam, rather than a continuous structure. Each panel has a steel-mesh ground plane with $75-80 \%$ optical transparency. This mesh is mounted on a steel framing structure, supported by steel columns in concrete footings. Aluminum conductors are used for the electrical power collection system.

\subsubsection{Terrestrial Photovoltaic System}

The reference terrestrial photovoltaic (TPV) alternative is a 200MWe system, which utilizes silicon cells on fixed-tilt, flat-plate solar arrays in eight 25-MWe modular components. The reference system, which does not include storage, is based primarily on designs published in a 1978 EPRI study. 9 That study defined the cost and performance goals for utility photovoltaic conversion devices and assessed the effects of photovoltaic generation on electric utility systems.

The reference TPV. system is assumed to have a silicon solar cell efficiency equal to that of the SPS silicon cell, or $17 \%$. (A cell efficiency of $12 \%$ was assumed in the EPRI sțudy.). This modification alters the EPRI design in so far as it reduces by approximately $30 \%$ the number of solar cells required to generate $200 \mathrm{MW}$. Overall plant costs and material requirements 
are affected, but such factors as total site area are assumed to remain unaltered.

Eight 25-MW modules of photovoltaic arrays are connected radially to a 34.5-kV switchyard, which, in turn, supplies the transmission grid through a step-up transformer. Each module is composed of the solar array field and its connecting DC cables and main bus, the DC-to-AC converter station, and the AC medium-voltage connection to the 34.5-kV switchyard. Within each module, the photovoltaic cells are connected in series and parallel to provide as high a voltage as-practical. Th1s produces inpruved inverter efficiency and lowest DC cable losses. The arrangement is such that $\pm 5,200 \mathrm{~V} \mathrm{DC}$ and $2,438 \mathrm{VAC}$ are provided at the inverter input. Each module contains $59.8 \times 10^{6}$ cells measuring $0.05 \mathrm{~m} \times 0.05 \mathrm{~m}$ ( 2 in. $\times 2$ in.). Each cell produces 0.43 watts of power at a nominal peak insolation of $1 \mathrm{~kW} / \mathrm{m}^{2}$. Total cell area in each module is $0.15 \mathrm{~km}^{2}$; the entire module, which includes structural components and the converter, covers $0.27 \mathrm{~km}^{2}$.

Figure 3.4 is a schematic of the performance chain of the refercnce terrestrial photovoltaic system. A maximum of $200 \mathrm{MWe}$ at $230 \mathrm{kV}$ and $60 \mathrm{~Hz}$ is generated at the busbar after accounting for a $0.5 \%$ ( 1 MWe) auxiliary power requirement and a $2 \%$ power loss in the DC cables and busses.

The plant capacity factor can be highly variable since it is critically dependent on the plant's geographic location. Capacity factors have been estimated to range from nearly 37\%. in the Phoenix area to just under $18 \%$ in Boston. An intermediate factor of $25 \%$ was chosen for this analysis.

The reference system is designed to occupy a $4.0-\mathrm{km}^{2}$ site, which houses the solar arrays, switch gear, transformer station, and personnel buildings. Excluding periodic maintenance crews, staff requirements total

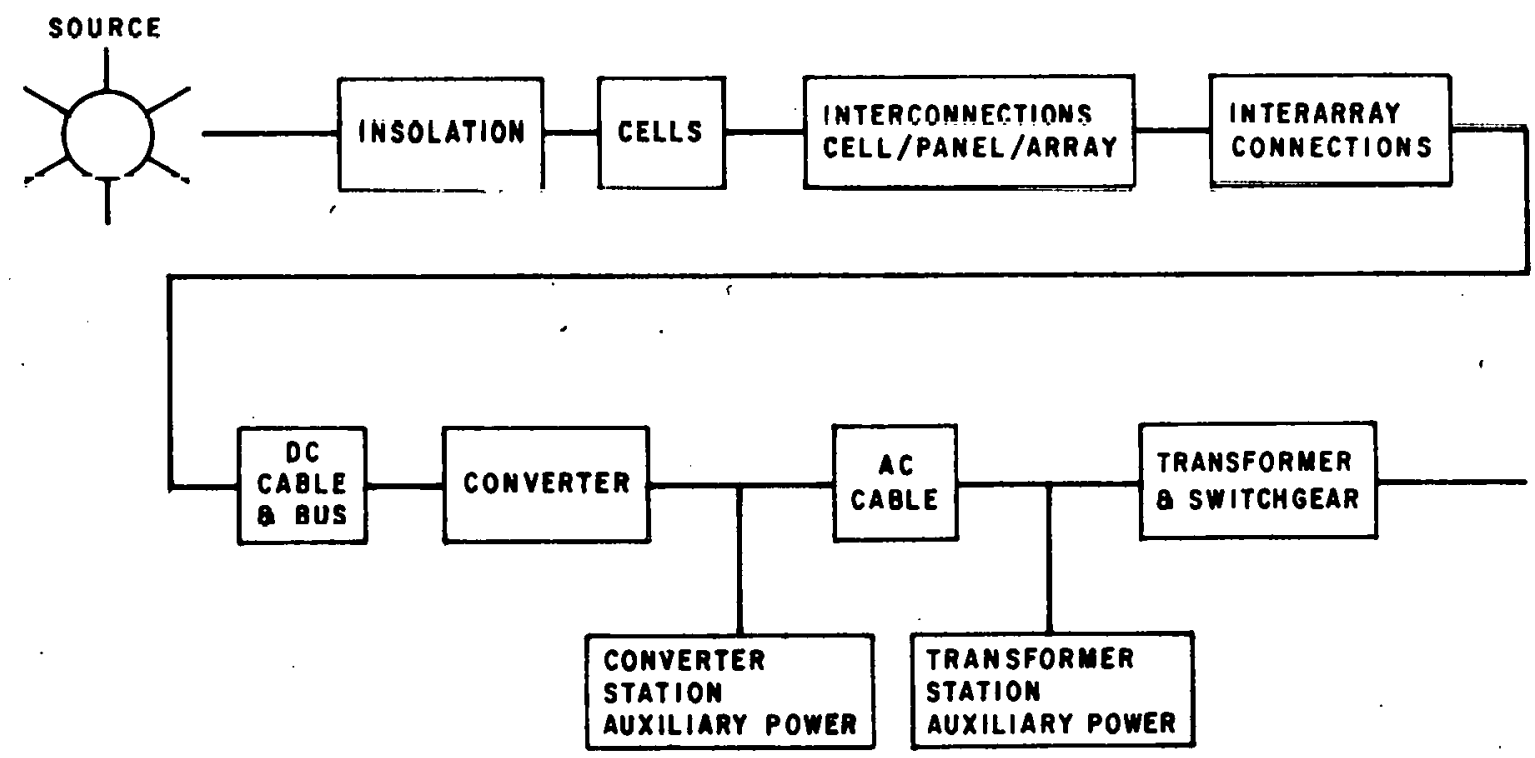

Fig. 3.4. Photovoltaic Plant Performance Chain (Source: Ref. 9, p. E-37) 
about 15 persons, with a larger number of personnel required during periods of scheduled or emergency maintenance.

Environmental residuals from the plant site should be minimal under normal operating conditions. No air emissions should result from the normal operation of the system, and any. waste heat should be removed from the arrays by natural convection. Small amounts of waste and garbage should be generated by personnel on site and small amounts of combustion products should be associated with on-site maintenance vehicles. A small unquantified amount of runoff should also be associated with cleaning of the solar arrays. However, environmental residuals would also be generated as a result of the cell manufacturing process, but these effects have not yet been characterized.

\subsubsection{High-Sulfur Coal Power Plant 10}

The reference high-sulfur coal power plant is a 1,250-MWe single-unit facility, consisting of a boiler system with pulverized-coal burners, a fluegas cleanup system consisting of electrostatic precipitators for particulate removal, and limestone scrubbers for sulfur dioxide $\left(\mathrm{SO}_{2}\right)$ reduction. The flue gas is emitted from a $225-\mathrm{m}$ stack at a temperature of $120^{\circ} \mathrm{C}$. Figure 3.5 is a diagram of the functional plant components.

Superheated steam is used to drive the main turbines and generators. This steam is produced at $24.1 \times 10^{6} \mathrm{~N} / \mathrm{m}^{2}$, and superheated to $540^{\circ} \mathrm{C}$ with $540^{\circ} \mathrm{C}$ reheat. With cooling towers, production of this steam requires 10,454 $\mathrm{kJ}$ of coal to produce a kilowatt-hour of electricity. Thus, the 1,250-MWe

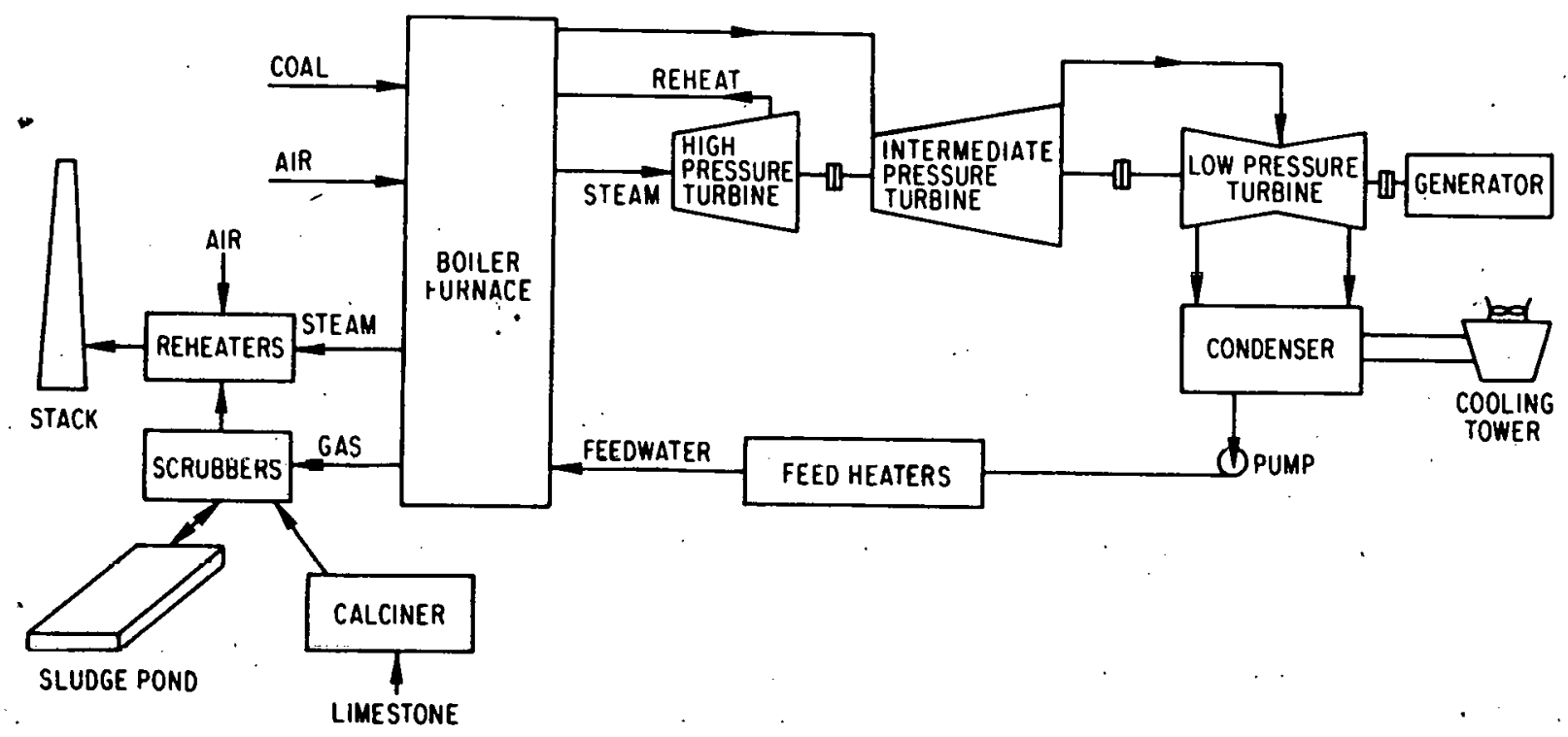

Fig. 3.5. Coal Steam Plant with Wet Gas Scrubbing

(Source: Ref. 3, p. A13) 
facility operates at an overall efficiency of $34 \% *$ and has a thermal operating capacity of 3,680 MWt .

The reference system is designed to burn an Illinois coal with a higher heating value of $25,570 \mathrm{~kJ} / \mathrm{kg}$, a sulfur content of $3.5 \%$, and the following properties as received at the facility: moisture, $13.0 \%$; volatiles, $36.7 \%$; fixed carbon, $40.3 \%$; and ash, $10.0 \%$. Waste heat from the plant is used to dry the coal to $10 \%$ moisture prior to combustion.

Coal is received at the unloading facility. From there it is moved to either of two stockpiles: the live storage pile or the reserve storage pile. The live storage pile must contain a minimum tonnage sufficient to maintain a steady supply to the burners between scheduled coal shipments. The reserve storage stockpile will typically hold a 50-day supply to allow for interruptions in delivery. The pile arrangement allows easy movement of coal from permanent to live storage by crawler tractors with push blades.

The coal is conveyed from the live storage pile to a crusher house and on to a surge bin. The surge bin is the primary device for smoothing out the delivery of coal to the burner feed system. The conveyor that feeds the surge bin is equipped with a sampler that continually monitors the energy content of the coal so that the amount of coal required to meet boiler load demand can be estimated. The surge bin is also equipped with collectors to remove excess dust and reduce the risk of explosion. The coal is conveyed from the surge bin either to silos or to bunkers, which feed the burners or the furnaces. A boiler, fired by pulverized-coal burners has a pulverizer incorporated in the feed system from each silo, and the pulverized coal must be mixed with a measured amount of preheated air.

Table 3.6 lists the approximate area required for each compunul of the model 1,250-MWe plant. The coal-handling facility is assumed to accommodate unit trains and includes only the siding on which the cars are staged for unloading; it does not include the railroad spur to the site. Mechanicaldraft wet cooling towers are assumed for dispersal of waste heat.

Coal consumption is estimated from the thermal capacity of the plant design, the heating value of the coal supply, and the plant capacity factor, assumed to be $70 \%$ for this analysis. Cnal requirements are estimated at an average of 363 metric tons/hour or $3.2 \times 10^{6}$ metric tons/year. At this rate, 8,700 metric tons of coal would be delivered to the facility each day, 434,900 metric tons of coal would be stored in the reserve storage stockpile, and 11,340 metric tons of coal would be stored in the live storage stockpile. The average storage density of coal is 1.10 metric tons $/ \mathrm{m}^{3}$ for live storage and 1.29 metric tons $/ \mathrm{m}^{3}$ for reserve storage, which translates to storage volumes of $10,300 \mathrm{~m}^{3}$ and $337,000 \mathrm{~m}^{3}$, respectively.

Water consumption for the reference coal system is based on the use of cooling towers and is estimated to be $45.4 \times 10^{3} \mathrm{~m}^{3}$ per day, due primarily to evaporation losses. About $75.7 \times 10^{3} \mathrm{~m}^{3}$ per day would be withdrawn, with $30.3 \times 10^{3} \mathrm{~m}^{3}$ per day being returned directly to the aquatic

*EPRI Technical Assessment Guide PS-1201-SR, July 1979, shows overall net efficiencies ranging from $32.2-35.1 \%$. 
Table 3.6. Approximate Component Areas Required for a 1,250-MWe Reference Coal Plant

\begin{tabular}{lr}
\multicolumn{1}{c}{ Component } & Area, $\mathrm{m}^{2}$ \\
\hline Power Generation & \\
$\quad$ Boiler & 4,650 \\
Turbine/generator & 4,650 \\
$\quad$ Subtotal & 9,300 \\
Fuel Handling & \\
$\quad$ Railroad siding & 9,000 \\
Coal stockpile (permanent) & 5,000 \\
Live storage pile/surge bins & 5,000 \\
$\quad$ Subtotal & 24,000 \\
Waste Heat Dispersal & 92,900 \\
Cooling towers & \\
Waste Handling & $6,132,000$ \\
Ash and sludge ponds & $6,258,200$ \\
$\quad$ Total & \\
\hline
\end{tabular}

environment as blowdown. An additional $3.8 \times 10^{3} \mathrm{~m}^{3}$ per day of withdrawal and consumption would be necessary for the operation of the $\mathrm{SO}_{2}$ scrubbers.

Coal combustion for electric power generation results in emissions of sulfur oxides, nitrogen oxides, and particulate matter or fly ash. Other emissions include trace elements and some radionuclides. These are discussed more fully in Sec. 4.3.

Electrostatic precipitators are used for control of particulate emissions. High overall mass collection efficiencies ( $>99 \%$ and up to $99.9 \%$ ) can be achieved at a low pressure drop through the precipitatior and at a low power requirement. The fly ash $(0.1-1 \%$ of the tortal fly ash) that escapes the precipitator is smaller than $1 \times 10^{-4}$ or $2 \times 10^{-4} \mathrm{~cm}$.

Sulfur dioxide emissions are controlled by wet limestone scrubbers. Figure 3.6 is a simplified flow diagram of the sulfur removal process. The limestone scrubbing process is capable of $90 \% \mathrm{SO}_{\mathbf{x}}$ removal trom flue gas. The supply of limestone to the scrubber flows at a rate of 1,285 metric tons per day:

Primary air residuals are based on collcction efficienries of $99.5 \%$ for particulates and $90 \%$ for $\mathrm{SO}_{\mathrm{x}}$. Uncontrolled $\mathrm{NO}_{\mathrm{x}}$ emissions are about $8 \mathrm{~kg}$ per metric ton of coal consumed. The wet scrubbers should remove about $25 \%$ of this, for a stack emission rate of $6 \mathrm{~kg} \mathrm{NO}$ per metric ton of coal. Plant emissions, in metric tons/day and $\mathrm{kg} / 10^{6} \mathrm{~kJ}$, are summarized in Table 3.7.

Sludge from the wet limcetone scrubbers and from the fly and bottom ash, which is also assumed to be sluiced to on-site settling ponds, is generated at a rate of about 5,440 metric tons per day as final settled sludge 


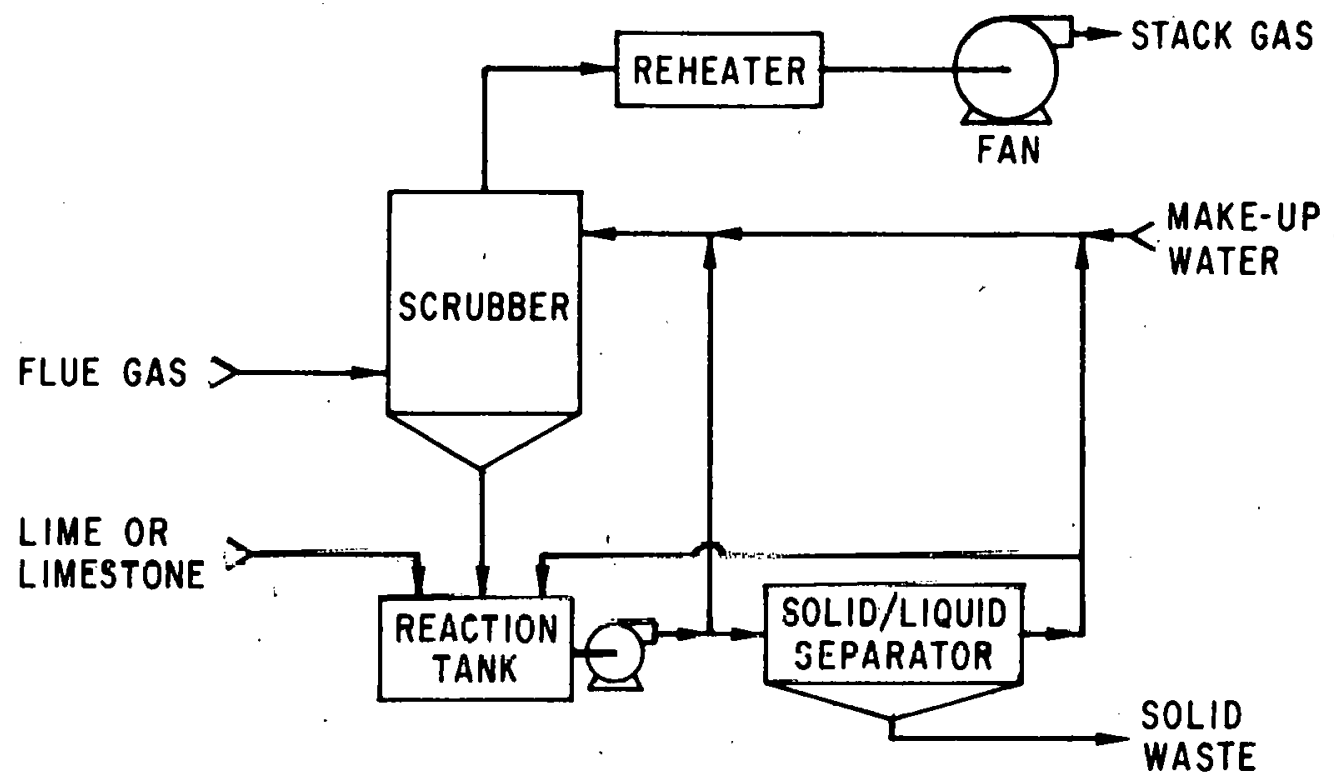

F1g. 3.6. Basic Flow Scheme for Limestone Scrubbing Processes

(after much of the excess water has been evaporated). Settled sludge is about $50 \%$ water and has a density of $1,440 \mathrm{~kg} / \mathrm{m}^{3}$. Thus, about $377 \mathrm{~m}^{3}$ of sludge is generated each day. A typical settling pond depth is 6-15 $\mathrm{m}$ so that an average land area of $560 \mathrm{~m}^{2}$ is consumed for this purpose each day of plant operation.

Additional environmental residuals are associated with the wining and transportation of the coal. These impacts are diocussed in the lechluology characterizalium report prepared by $\mathrm{TRW}^{3}$ and in Sec. 4.3 of this assessment.

\subsubsection{Coal-Gasification/Combined-Cycle Power Plant $4,11,12$}

The unit deplcted in Fig. 3.7 is a 630-MWe power plant fired by gas= Ifled coal. The reference design coal-gasification/combined-cycle system is a single plant composed of two such unit.s. The coal ic gaoificd in air air-blown entrained-bed gasifier. The resulting gas, which has a low heating value, is cleaned, and the sulfur is removed using the stretford process. The clean gas is compressed and burned in gas turbines, which generate 260 MWe. The exhaust gas from the gas turbines passes through waste heat boilers to produce steam,

Table 3.7. Reference Coal Plant Air Emissions

\begin{tabular}{lcc}
\hline \multicolumn{1}{c}{ Residual } & Metric tons/day & $\mathrm{kg} / \mathrm{million} \mathrm{kJ}$ \\
\hline $\mathrm{SO}_{\mathrm{x}}$ & 61 & 0.26 \\
$\mathrm{NO}_{\mathrm{x}}$ & 53 & 0.21 \\
Particulates & 5 & 0.02 \\
\hline
\end{tabular}




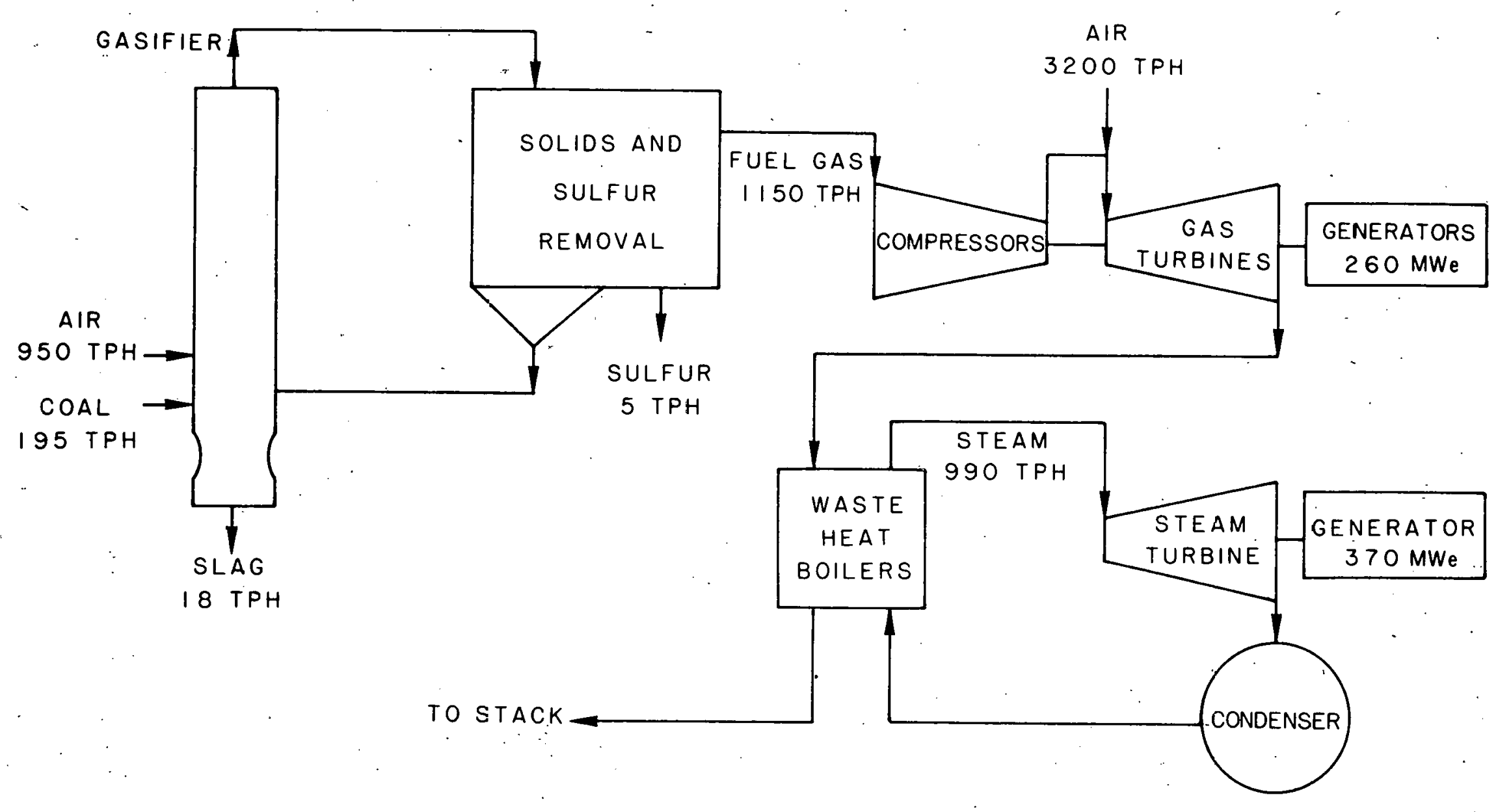

Fig. 3.7. Coal-Gasification/Combined-Cycle Electric Power Plant (Source: Ref. 12) 
which drives a 370-MWe steam turbine-generator. The net unit output is 630 MWe; net plant output is 1,260 MWe. The net station heat rate is 9,610 $\mathrm{kJ} / \mathrm{kWh}$, which means that plant efficiency is about $38 \%$.

The coal handling system is standard for a power plant of this size. Railroad cars dump to a hopper-type unloader. Coal storage space will hold a 90-day reserve. The reference plant is designed to burn 177 metric tons per hour of Pittsburgh Seam coal in each unit $(31,390 \mathrm{~kJ} / \mathrm{kg}, 2.6 \%$ sulfur, $2.4 \%$ moisture). However, the entrained-bed gasifier is capable of using a wide range of coals.

The ash handling system is sized to handle 16 metric tons per hour of molten slag from each unit. Each unit has two 91-metric-ton/hr atmosphericpressure, entrainment gasifiers. They are air blown and tangentially fired, using conventional heating surtaces and fans, A conventional air heater, either regenerative or tubular, will supply preheated air at about $315^{\circ} \mathrm{C}$.

Each gasifier is about $55 \mathrm{~m} \mathrm{tall}$, and has a maximum cross-sectional dimension of about $9 \mathrm{~m}$. The reaction chamber consists of lower and upper reaction zones separated by a reduced cross-section throat, or diffuser zone, intended to minimize mixing of reactants between the upper and lower zones. The lower zone of the reaction chamber is an oxidizing zone in which pulverized coal and recycled char are completely. burned in order to fuse the ash in the fuel and to produce the heat required for the endothermic reduction reactions that occur in the upper chamber of the gasifier, called the reducing zone or reductor. The remainder of the pulverized-coal feed to the gasifier is injected into the lower part of the reductor, where devolatilization of this coal and initiation of the reduction reactions occur. The reduction reactions continue throughout the height of the reductor.

'l'he gas temperature in the oxidizer is about $1,760^{\circ} \mathrm{C}$. The temperature of gas leaving the reductor will be about $930^{\circ} \mathrm{C}$. The gases are cooled to about $150^{\circ} \mathrm{C}$ by the convection-cooling surface in the back pass of the gasifier structure. A portion of the convection-cooling surface will be one-half of a "liquid couple" -- a sensible-heat recovery device that removes heat from the gas at this point and puts the same sensible heat back into the gas after it is cleaned and before it is burned in a boiler or gas turbine, Each gasifier will process 91 metric tons of coal per hour and produce fuel gas with a heating value of 4,480 to $4,850 \mathrm{~kJ} / \mathrm{m}^{3}$ at atmospheric pressure.

This fuel gas will be compressed and fired in four (per unit) advanced air-cooled gas turbines rated at $65 \mathrm{MW}$ each. Four waste heat boilers per unit will convert the turbine exhaust gas heat to steam. Primary steam production will be approximately 227 metric tons/hr at $17.9 \times 10^{6} \mathrm{~N} / \mathrm{m}^{2}$ and $538^{\circ} \mathrm{C}$ from each boiler. This steam will drive a single 370-MWe steam turbine generator before being condensed and cooled by a natural or mechanical-draft cooling tower.

Water consumption for the two-unit plant will be about $31,800 \mathrm{~m}^{3}$ per day. Of this total; $1,515 \mathrm{~m}^{3}$ per day will be consumed in the gasification process, with the remainder being evaporated from the cooling towers. 
Gas from the gasifier units needs to be substantially free of sulfur and particulates before it is fired in the gas turbines. The Stretford process is used to remove sulfur as $\mathrm{H}_{2} \mathrm{~S}$ from the low-Btu gas stream. Removal efficiencies for the stretford process are high, resulting in a sulfur concentration in the outlet gas of less than l ppm. Sulfurous oxide is emitted as a result of the sulfur recovery process, which converts the $\mathrm{H}_{2} \mathrm{~S}$ to elemental sulfur at a $95 \%$ recovery efficiency. At this rate, about 0.9 metric ton per hour or $0.09 \mathrm{~kg} / 10^{6} \mathrm{~kJ}$ of $\mathrm{SO}_{2}$ would be emitted from the two-unit plant.

Particulate removal efficiencies are high, and less than $0.004 \mathrm{~kg} / 10^{6}$ $k J$ of particulate matter would be emitted. NO $\mathrm{x}_{\mathrm{x}}$ emissions resulting from the conversion and combustion process would total $0.13 \mathrm{~kg} / 10^{6} \mathrm{~kJ}$.

Solid wastes would be primarily ash and elemental sulfur. These are assumed to be disposed of on site at rates of 35.4 metric tons/hour and 8.7 metric tons/hour, respectively. Over the 30-year 1 ifetime of the facility these wastes would occupy $9.25 \times 10^{6} \mathrm{~m}^{3}$ and $1.15 \times 10^{6} \mathrm{~m}^{3}$, respectively. Total land use assuming $a 9-m$ height, would be $1.13 \mathrm{~km}^{2}$. Total site area would be approximately $2.0 \mathrm{~km}^{2}$ with $0.2-0.25 \mathrm{~km}^{2}$ occupied by plant facilities.

\subsubsection{Light Water Reactor Power Plant $3,4,13,14$}

The reference light water reactor (LWR) power plant is a 1,250-MWe single-unit facility consisting of a pressurized water reactor supplying superheated steam to a conventional turbine generator. Condenser cooling is accomplished with a cooling tower.

The reference LWR shown in the flow diagram of Fig. 3.8 has a thermal power rating of $3,810 \mathrm{MWt}$ and a net heat rate of $10,980 \mathrm{~kJ} / \mathrm{kWh}$. Net electrical capacity is 1,250 MWe after accounting for $50 \mathrm{MW}$ of in-plant electrical power consumption.

The reference LWR plant operates on the principle of two closed cycles, as shown in Fig. 3.8, in which the reactor coolant does not come in contact with the steam being generated. The primary cycle, or reactor coolant system (RCS), contains high-temperature, high-pressure coolant water, which flows through the reactor vessel where it picks up the heat generated by the nuclear fission taking place in the uranium fuel. From the reactor vessel the heated water passes on to a large heat exchanger, known as the steam generator, which functions as the connecting link between the primary and secondary cycles. As the primary coolant passes through the thousands of steam generator tubes; its heat is transferred to the secondary feedwater to generate steam for the turbine-generator. The primary cycle is completed as the coolant exits from the steam generator and is pumped back to the reactor vessel. A pressurizer is used to maintain a constant primary system pressure of $15.5 \times 10^{6} \mathrm{~N} / \mathrm{m}^{2}$. The secondary, or turbine-generator cycle, contains non-radioactive water as the working fluid. Boiling takes place on the shell side of the steam generator, as the incoming feedwater surrounds the tubes and is heated by the primary coolant. The high-energy steam is directed to the turbine-generator, where the thermal energy stored in the 


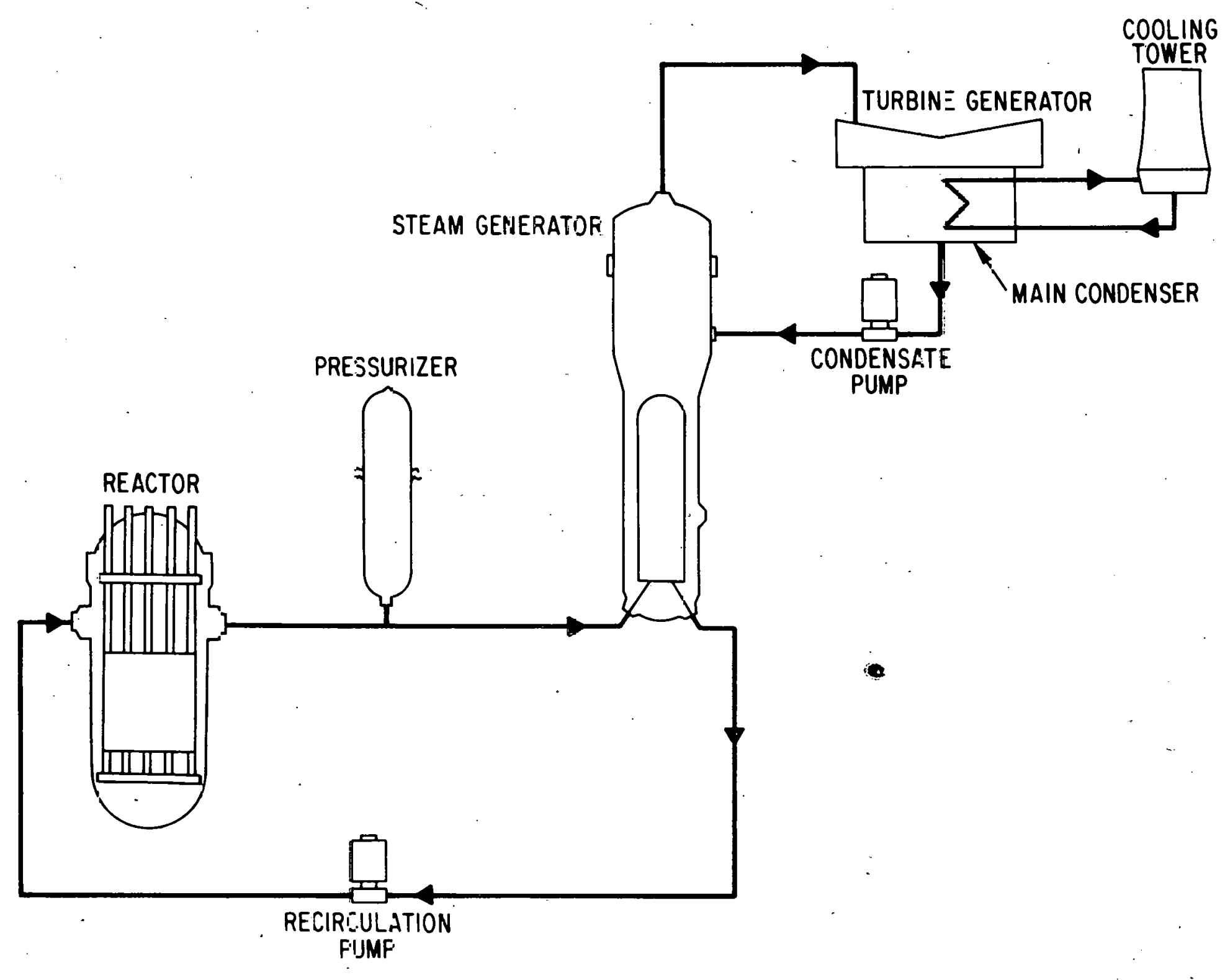

Fig. 3.8. Simplified LWR Flow Diagram (Sour:e: Ref. 3) 
steam is converted to mechanical, and finally to electrical, energy. After passing through the turbine, the exiting low-energy steam j.s condensed in a large heat exchanger and then pumped back to the steam generator to complete the secondary cycle.

The nuclear fuel used in the reference LWR is slightly enriched $(<3.5 \%) \mathrm{UO}_{2}$ in pellet form. The fuel pellets are stacked in $\mathrm{Zircaloy}$ cladding tubes to form fuel rods, which are then assembled into square-array fuel assemblies. A core load or complement of fuel consists of approximately 200 fuel assemblies.

The first core load, made up entirely of new fuel, is retained over an operating life of one to two years. Subsequently, a portion of the load or a "batch" is discharged and replaced by new fuel at periodic intervals. Refueling the reactor at a nominal burnup rate of 28,000 MWt-day/metric'ton involves the yearly interchange of some 70 fuel assemblies (i.e., one-third of a core), representing approximately 35 metric tons of $\mathrm{UO}_{2}$. The new fuel must be transferred and stored on site. The discharged or spent fuel is allowed to decay for a period of time in the spent-fuel storage pool.

The reference facility would be situated on a $4.85 \mathrm{~km}^{2}$ site. About $0.6 \mathrm{~km}^{2}$ would be taken for structures associated with the plant such as access roads, switch yards, turbine and reactor buildings, and the cooling tower.

About $140 \times 10^{3} \mathrm{~m}^{3}$ of water per day would be withdrawn from a natiral water body. Evaporation and cooling-tower drift losses would account for as much as $87 \times 10^{3} \mathrm{~m}^{3} / \mathrm{day}$, and blowdown would account for most of the remaining $53 \times 10^{3} \mathrm{~m}^{3}$. A small amount of water would also be consumed for various inplant services. These values compare to an equilibrium circulation of about $3.8 \times 10^{6} \mathrm{~m}^{3}$ per day. During operation of the reference LWR system, radioactive material would be produced by fission and by neutron activation reactions in metals and other materials in the reactor coolant system. Small amounts of gaseous and 1 iquid radioactive wastes would enter the waste streams. These streams would be monitored and processed through the appropriate radwaste systems prior to release to the environment: Table 3.8 summarizes the sources and approximate amounts of radioactivity estimated to bè released each year in the model LWR liquid and gaseous waste streams.

An estimated volume of $225 \mathrm{~m}^{3}$ of miscellaneous dry and sludge wastes would be shipped offsite each year. The total activity of the solid wastes would be about 8,250 curies ( $\mathrm{C} i$ ).

Small amounts of additional wastes, including $90 \mathrm{~kg}$ of sanitary sludge: per day, will be genérated during plant operations. Operation of emergency diesel engines during tests would produce the following amounts of air residuals on an annual basis: $\mathrm{CO}, 3,400 \mathrm{~kg}$; $\mathrm{NO}_{\mathrm{x}}, 9,300 \mathrm{~kg}$; $\mathrm{SO}_{\mathrm{x}}, 50 \mathrm{~kg}$; and hydrocarbons, $900 \mathrm{~kg} .14$

Other environmental residuals are associated with the nuclear fuel cycle, but, as with the coal technologies, these are not addressed here but are covered in detail in the main characterization reports. 3,4 
Table 3.8. LWR Liquid and Gaseous Radioactive Emissions

\begin{tabular}{|c|c|c|}
\hline \multicolumn{2}{|c|}{ Source/Type } & Curies $(\mathrm{Ci}) / \mathrm{yr}$ \\
\hline \multicolumn{2}{|c|}{$\left.\begin{array}{l}\text { Liquid Streams } \\
\text { Equipment Drainage } \\
\text { Floor Drain System } \\
\text { Chemical Waste Sources } \\
\text { Tritium }\left(\mathrm{H}^{3}\right)\end{array}\right\}$} & $\begin{array}{c}0.4-4.0 \\
350\end{array}$ \\
\hline $\begin{array}{l}\text { Gaseous St } \\
\text { Krypton } \\
\text { Krypton } \\
\text { Krypton } \\
\text { Kryptcn } \\
\text { Krypton } \\
\text { Xenon } \\
\text { Xenon } \\
\text { Xenon } \\
\text { Xenon } \\
\text { Iodine } \\
\text { Iodine } \\
\text { Tritium } \\
\text { Carbon }\end{array}$ & $\begin{array}{l}\text { reams } \\
-\quad 85 \mathrm{~m} \\
-\quad 85 \\
\cdots \quad 87 \\
-\quad 88 \\
-\quad 89 \\
-133 \text { and } 133 \mathrm{~m} \\
-135 \\
-137 \\
-138 \\
-131 \\
-133 \\
-14\end{array}$ & $\begin{array}{c}14 \\
500 \\
3 \\
19 \\
-a \\
9,520 \\
70 \\
-a \\
1 \\
0.07 \\
0.08 \\
760 \\
8\end{array}$ \\
\hline Total & Gaseous Emissions & $\sim 10,895$ \\
\hline
\end{tabular}

Source: Ref. 13, pp. 3-12, 3-15

a Less than $1 \mathrm{Cl} / \mathrm{yr}$.

\subsubsection{Liquid-Metal, Fast-Breeder Reactor ${ }^{3}, 4$}

The liquid-metal, fast-breeder reactor (LMFBR) reference plant is a 3,480-MWt loop-type, sodium-cooled, fast-breeder reactor plant with a nominal electrical rating of 1,250 MWe. The design operates at a $70 \%$ capacity factor with $10,032 \mathrm{~kJ} / \mathrm{kWh}$ heat rate ( $36 \%$ thermal efficiency) utilizing conling towers for waste heat dissipation.

The LMFBR is a fission reactor, which, in addition to producing energy, converts $U^{238}$ in its core to plutonium at a rate that produces more fissile material ( $\mathrm{Pu}^{239}$ and $\mathrm{Pu}^{241}$ ) than is consumed. Liquid sodium is used to remove heat from the reaction and to power the steam cycle to generate electrical power. Excess plutonium produced by the LMFBR would provide fuel for other breeders as well as for conventional light water reactors.

The LMFBR has a central core with fuel elemento containing a mixture of $\mathrm{PuO}_{2}$ and $\mathrm{UO}_{2}$ (primarily U-238). Fission of the $\mathrm{Pu}$ in the core produces neutrons, which are absorbed by the U-238 contained in the core and in a blanket of U-238 that surrounds the central core. The U-238 is transmuted from U-238 to $\mathrm{Pu}-239$ by neutron capture and subsequent beta decay.

Liquid sodium is pumped through the reactor core, absorbing the heat produced there. The primary sodium has induced radioactivity, and an 
intermediate heat exchanger is used to transfer the heat to a second loop of nonradioactive sodium, which flows through the steam generator of a conventional steam cycle. Sodium can be heated to high temperatures at relatively low pressures, allowing the use of low-pressure cooling circuits that are less susceptible to failure than corresponding high-pressure cooling circuits used in light water reactors.

LMFBRs may operate at temperatures higher than LWKs, thus resulting in high plant thermal efficiencies of about $36 \%$ compared to $33 \%$ for conventional light water reactors. The increased efficiency results in a reduction in waste heat per unit of energy generated.

The nuclear-fuel cycle for LMFBRs is shown in Fig. 3.9. The initial feed materials consist of plutonium (obtained from the reprocessing of fuel

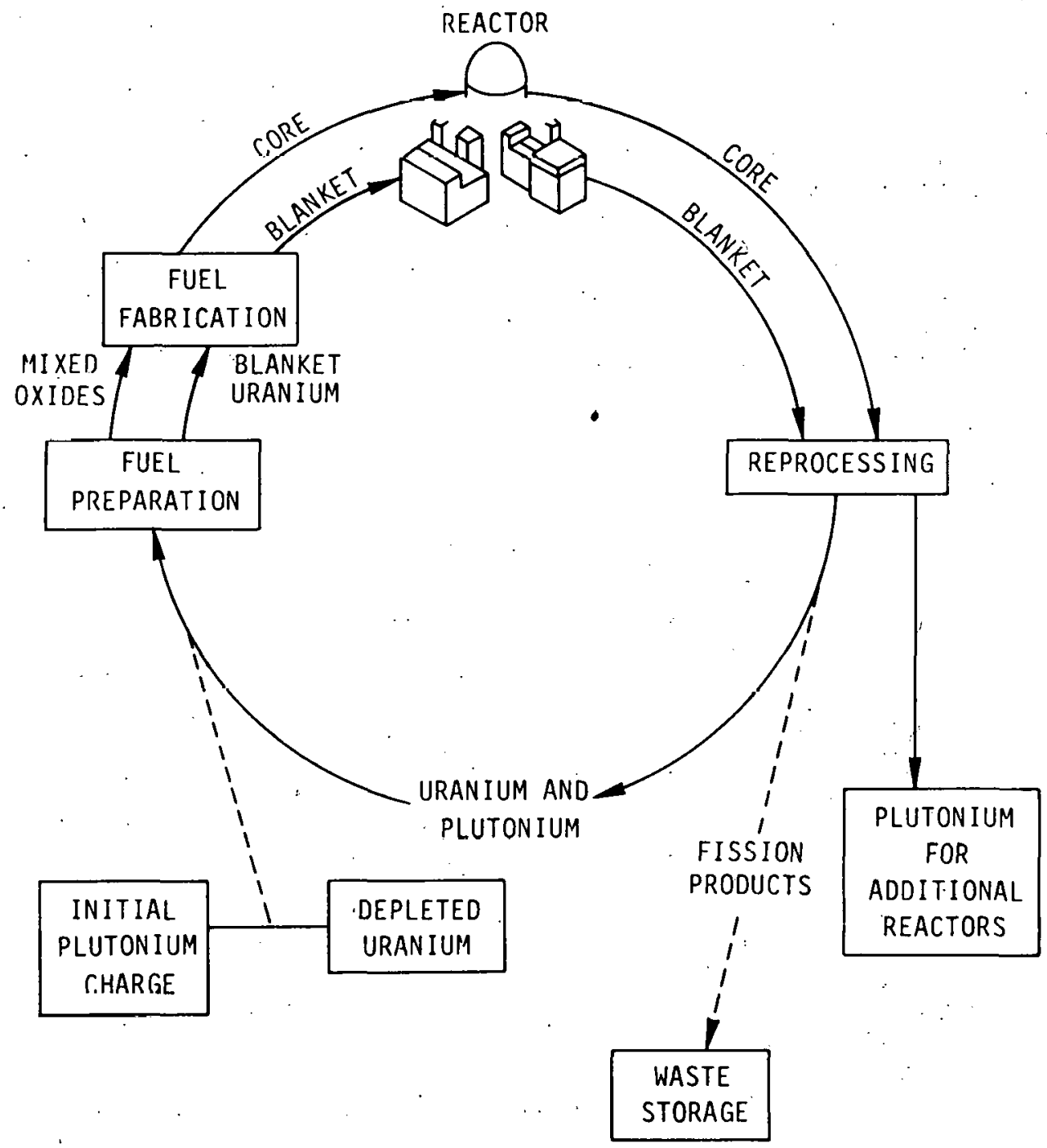

Fig. 3.9. Fucl Cycle for the Liquid-Metal, Fast-Breeder Reactor

*EPRI PS-1201-SP, July 1979 shows 34\% for overall net efficiency. 
from 1ight water reactors) and depleted uranium (by-products of. the U-235 enrichment process from natural uranium). The plutonium would be converted to an oxide $\left(\mathrm{PuO}_{2}\right)$ at the fuel-fabrication plant. Plutonium dioxide and uranium dioxide would be combined at the fuel-fabrication plant and fabricated into mixed oxides for the core fuel. Uranium dioxide would also be fabricated into pellets for the axial and radial blankets of the reactor- After exposure in the reactor, the irradiated fuels would be stored at the reactor for up to 360 days. After storage at the reactor, the irradiated fuel is shipped in shielded casks to the reprocessing plant, where the plutonium, uranium, and fission products would be chemically separated. The separated fission products would be shipped to a federal waste-storage facility, and the plutonium would be recycled as fuel.

The recovered uranium could be efther stored or recycled into the mixed oxide or blanket $U_{2}$. Depleted uranium would be used for makeup of the uranium that is either converted to plutonium in the reactor, lost as scrap in the processes, or stored.

The reference 1,250-MWe LMFBR power plant, shown schematically in Fig. 3.10, includes a reactor element consisting of a reactor core, control rods and drives, containment vessel and associated pumps, piping, instrumentation, and other equipment. The design also includes a heat transportation system and a power generation system, which consists of the sodium pumps, piping, intermediate heat exchangers, steam generators, turbine generators, and the condenser. Heat generated in the reactor core is transferred by forced circulation of liquid sodium primary coolant to intermediate heat exchangers and then through a secondary sodium coolant system to steam

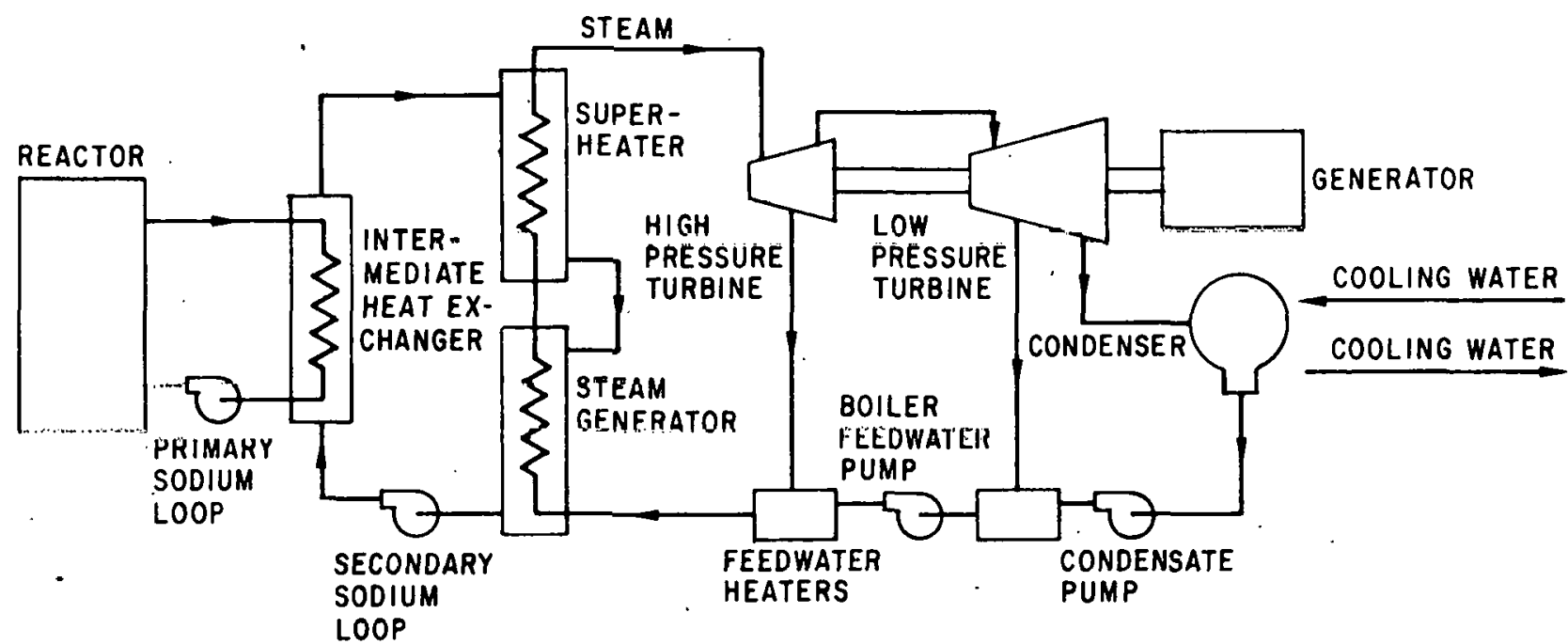

POWER GENERATION SYSTEM

Fig. 3.10. LMFBR Plant Schematic

(Source: Ref. 3) 
generators in which superheated steam is produced. This steam drives a turbine-generator to generate electrical power. Waste heat from the condenser is rejected to the atmosphere via mechanical-draft cooling towers. Table 3.9 lists some of the more important thermodynamic characteristics of the LMFBR steam cycle.

The reference plant contains a number of auxiliary systems that perform specific support functions: liquid metal receiving and processing; inert gas receiving and processing; impurity monitoring, sampling, and analysis; auxiliary heating and cooling; radioactive waste processing; and service and utility functions. Of these systems, radioactive waste processing systems are perhaps the most important in terms of environmental considerations.

The LMFBR primary system is a completely closed system in which the sodium and cover gas are continually purified to maintain radioactivity at low levels. Four radioactive waste processing systems are provided:

(1) gaseous waste system, subdivided into reactor cover
gas and cell atmosphere purification systems;
(2) liquid waste system;
(3) solid waste system; and
(4) sodium waste system

The relationship of these systems to the reactor system is shown in Fig. 3.11.

It is expected that commercial LMFBR power plants will be designed and operated so that there will be essentially no planned, continuous release of radioactivity to the environment, although some small leakage of radioactive gases through seals and diffusion of tritium through metal are anticipated. Intermittent releases from LMFBRs would include the discharge of steam-generator blowdown water containing small quantities of tritium.

Table 3.9. Thermodynamic Characteristics of LMFBR Steam Cycle

Primary coolant system arrangement

Number of coolant loops - primary/secondary

Reactor outlet temperature

Reactor inlet temperature

Primary coolant flow (sodium)

Secondary coolant hot-leg temperature

Secondary coolant cold-leg temperature

Secondary coolant flow per loop (sodium)

Primary and secondary cover gas

Main steam flow

Main. steam pressure

Main steam temperature

Reheat pressure

Reheat temperature

Condensate pressure and temperature:

Feedwater temperature.

$$
\begin{aligned}
& \text { Pool or loop } \\
& 3 / 3 \mathrm{~K} \\
& 538-566^{\circ} \mathrm{C} \\
& \sim 430^{\circ} \mathrm{C} \\
& 34-45 \times 10^{6} \mathrm{~kg} / \mathrm{h} \\
& 2538^{\circ} \mathrm{C} \\
& 343-400^{\circ} \mathrm{C} \\
& 189-265 \mathrm{~m}^{3} / \mathrm{min} \\
& \text { Argon } \\
& 3.1-3.3 \times 10^{6} \mathrm{~kg} / \mathrm{h} \\
& 10-16.5 \times 10^{6} \mathrm{~N} / \mathrm{m}^{2} \\
& 482^{\circ} \mathrm{C} \\
& 3.4-3.8 \times 10^{6} \cdot \mathrm{N} / \mathrm{m}^{2} \\
& 482-538^{\circ} \mathrm{C} \\
& 3.3 \mathrm{~cm} \mathrm{Hg} \text { and } \sim 32^{\circ} \mathrm{C} \\
& \sim 260^{\circ} \mathrm{C} \text {. }
\end{aligned}
$$




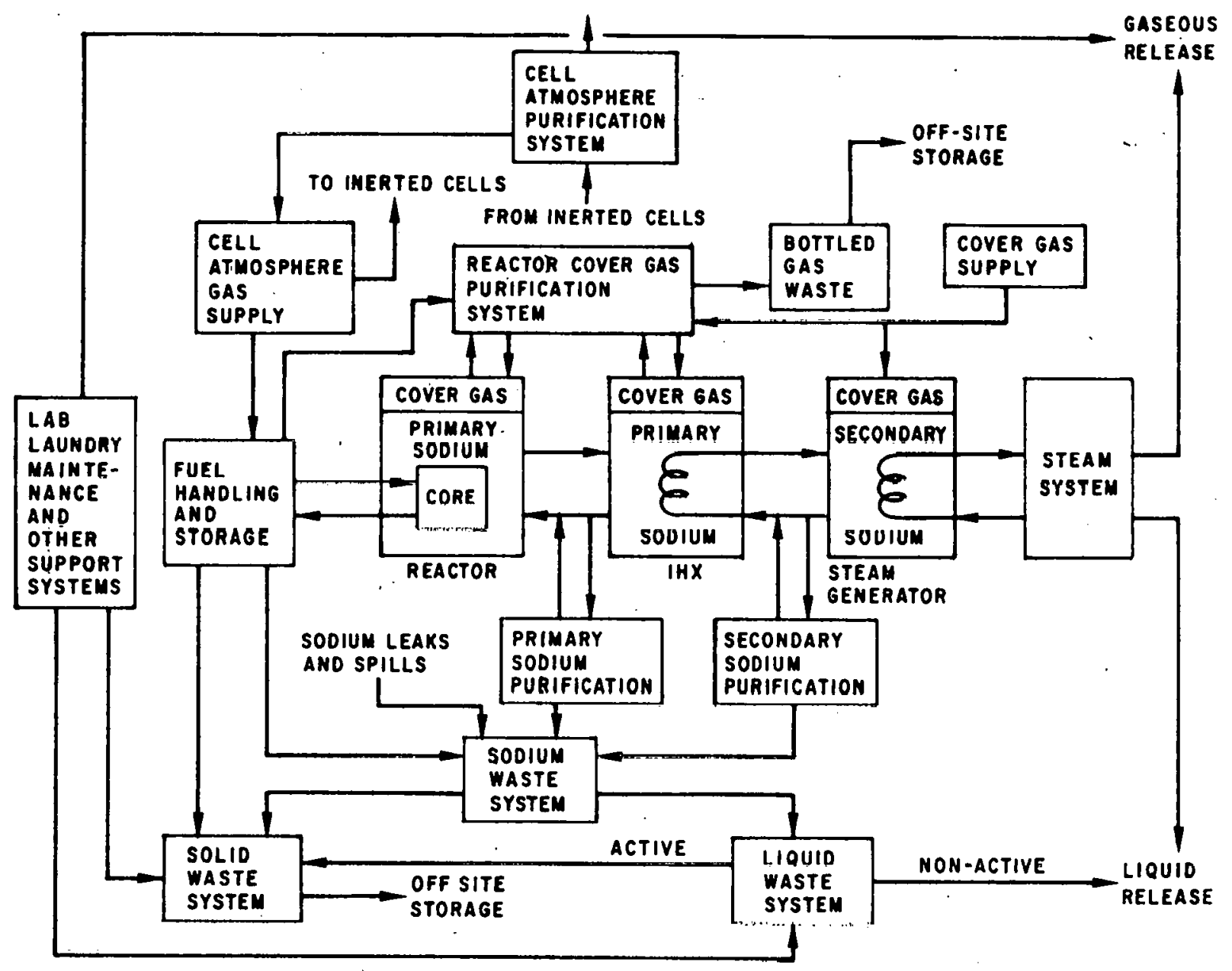

Fig. 3.11. LMFBR Radioactive Waste Systems

Gases other than tritium would, under normal operating conditions, be processed through one of two separate control systems -- the reactor covergas purification system or the cell atmospheric purification systen. The former would process radioactive gases generated in the reactor vessel whereas the latter would process effluents from all inert gas-filled enclosures surrounding all primary sodium piping systems. All gases other than tritium would be delayed and filtered prior to release to the atmosphere. Annual quantities estimated to be released to the atmosphere are given in Table 3.10.

The liquid waste system processes all potentially contaminated liquids before the liquids leave the plant. The sources of the liquid waste streams are the fuel handling area, the sodium waste system, laboratory areas, laundry, maintenance, and other support systems. The quantity of liquid waste entering the system is expected to be between 75 and $150 \mathrm{~m}^{3} / \mathrm{year}$, which is low-level.

Solid waste will be generated by most other waste systems, fuel handling operations, and laboratory and maintenance operations. The waste will be in forms such as spent resins, sludges, filters, clothing, and tools. Most of these wastes are dried or solidified, compacted into drums and shipped to offsite disposal sites. 
Table 3.10. Estimated Radionuclide Releases From a. 1,250-MWe LMFBR Reference: Plant

\begin{tabular}{lcc}
\hline Nuclide & $\begin{array}{c}\text { Liquid Release } \\
(\mathrm{Ci} / \mathrm{yr})\end{array}$ & $\begin{array}{c}\text { Atmospheric Release } \\
(\mathrm{Ci} / \mathrm{yr})\end{array}$ \\
\hline Tritium & - & 65.0 \\
Argon-39 & - & 85.0 \\
Krypton-85 m & - & 0.3 \\
Krypton-85 & - & 0.4 \\
Krypton-87 & - & 0.4 \\
Krypton-88 & - & 0.5 \\
Xenon-133 & - & 0.03 \\
Tritium & 65.0 & \\
\hline
\end{tabular}

Source: ANL stafí estimates based on Refs. 15 and 16 .

The purpose of the sodium waste system is to convert small amounts of metallic sodium waste, both radioactive and nonradioactive, into a less reactive form. After metallic sodium wastes have been chemically deactivated they will be routed either to the liquid waste system or the solid waste system for further treatment, discharge, or shipment.

Approximately 0.15 to $0.20 \mathrm{~km}^{2}$ of land will be required for facilities associated with an LMFBR power plant; namely, the reactor buildings, turbine building, switchyard, parking lot, access roads, and cooling towers. A minimum exclusion area of at least $1.6 \mathrm{~km}^{2}$ would be needed. It would be appropriate to assume that an LMFBR site might not be atypical of present 1 ight water reactor sites, which have an average size of about $50 \mathrm{~km}^{2}$.

Water consumption would be very similar to that of the 1,250-MWe coal-fired generation facility. Using cooling towers, water withdrawal would be about $76 \times 10^{3} \mathrm{~m}^{3}$ per day; evaporation losses, about $45 \times 10^{3} \mathrm{~m}^{3}$ per day; and blowdown about $31 \times 10^{3} \mathrm{~m}^{3}$ per day.

\subsubsection{Fusion ion $^{3}, 17$}

The fusion of hydrogen isotopes (deuterium, tritium) or other light elements shows potential for becoming a large-scale energy source sometime after the year 2000. However, a feasible technology capable of harnessing this snurce has not hepn demnnstrated even at the laboratory scale.

Several fusion-reactor concepts currently exist, including the magnetic-confinement Tokamak, magnetic mirror, Theta Pinch, and laser fusion. All of these have yet to show net energy production. If and when net energy production is shown, a host of practical engineering problems specific to the fusion reactor will need to be overcome before the concept can be demonstrated. Most of these problems include radiation damage of the reactor confinement, materials 1 imitations on heat fluxes and temperatures, and induced radioactive afterheat. The first of these is a far more severe 
problem than was experienced in the fission reactor development program and will probably require the periodic replacement of the fusion reactor confinement.

A schematic diagram of a generic magnetic-confinement fusion reactor is shown in Fig. 3.12. The plasma contained in the toroidal vacuum chamber is heated either by forcing the electrons in the plasma to move along the axis of the torus and hence to heat the plasma resistively (like current in a wire) or by injecting radio-frequency electromagnetic radiation or high-energy deuterium atoms. 'The toroidal chamber is surrounded by a blanket, wh1ch stores energy produced during periodic burn phases, providing a constanttemperature heat source to the steam cycle system and simultaneously breeding tritium fuel from lithium.

External to the blanket are radiation shields and the magnets and energy injertors. The magnets are used for plasma confinement and stabilization. The energy injectors are for plasma heating. Heat from the fusion blanket would be used to create steam for powering a conventional turbine generator as shown in Fig. 3.13.

Several fusion-reactor concepts exist; one called NUWMAK has been developed by the University of Wisconsin.17 'lhis concept assumes a Tokamak fusion reactor with an average thermal output of 2,097 MWt, a gross electrical power rating of 725 MWe and a net capacity of 660 MWe. Overall net plant

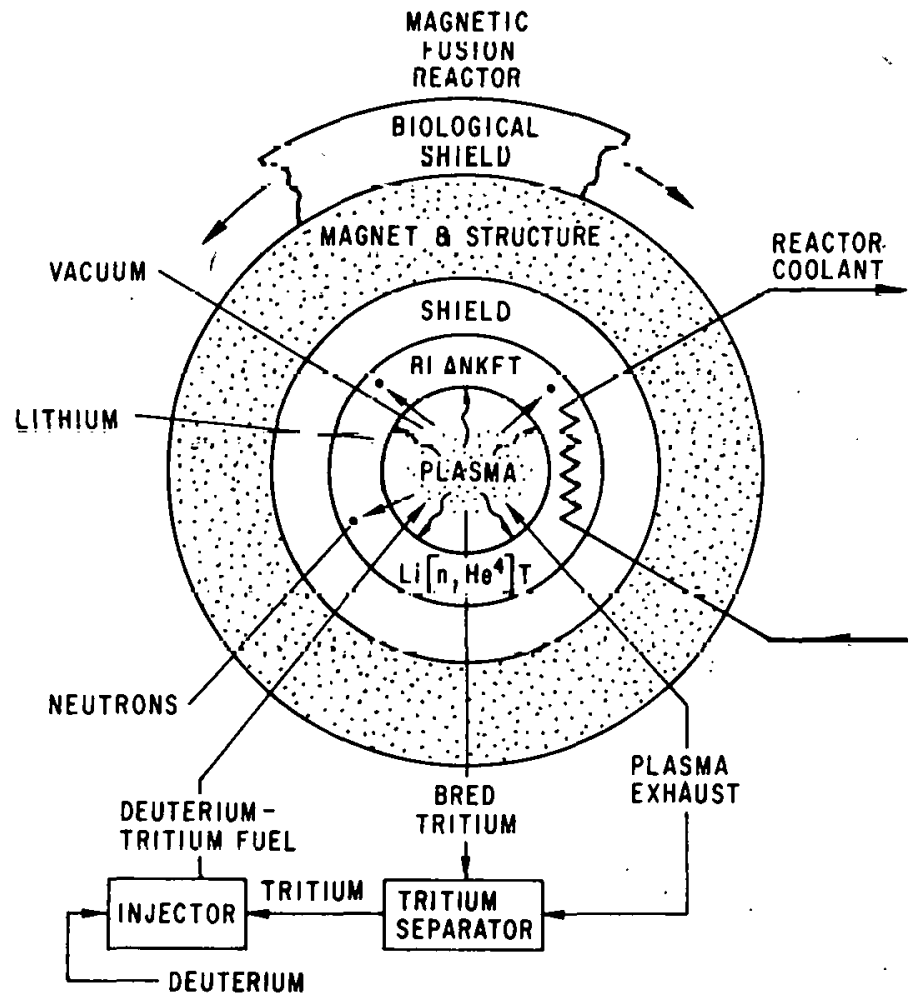

Fig. 3.12. A Generic Fusion Reactor 


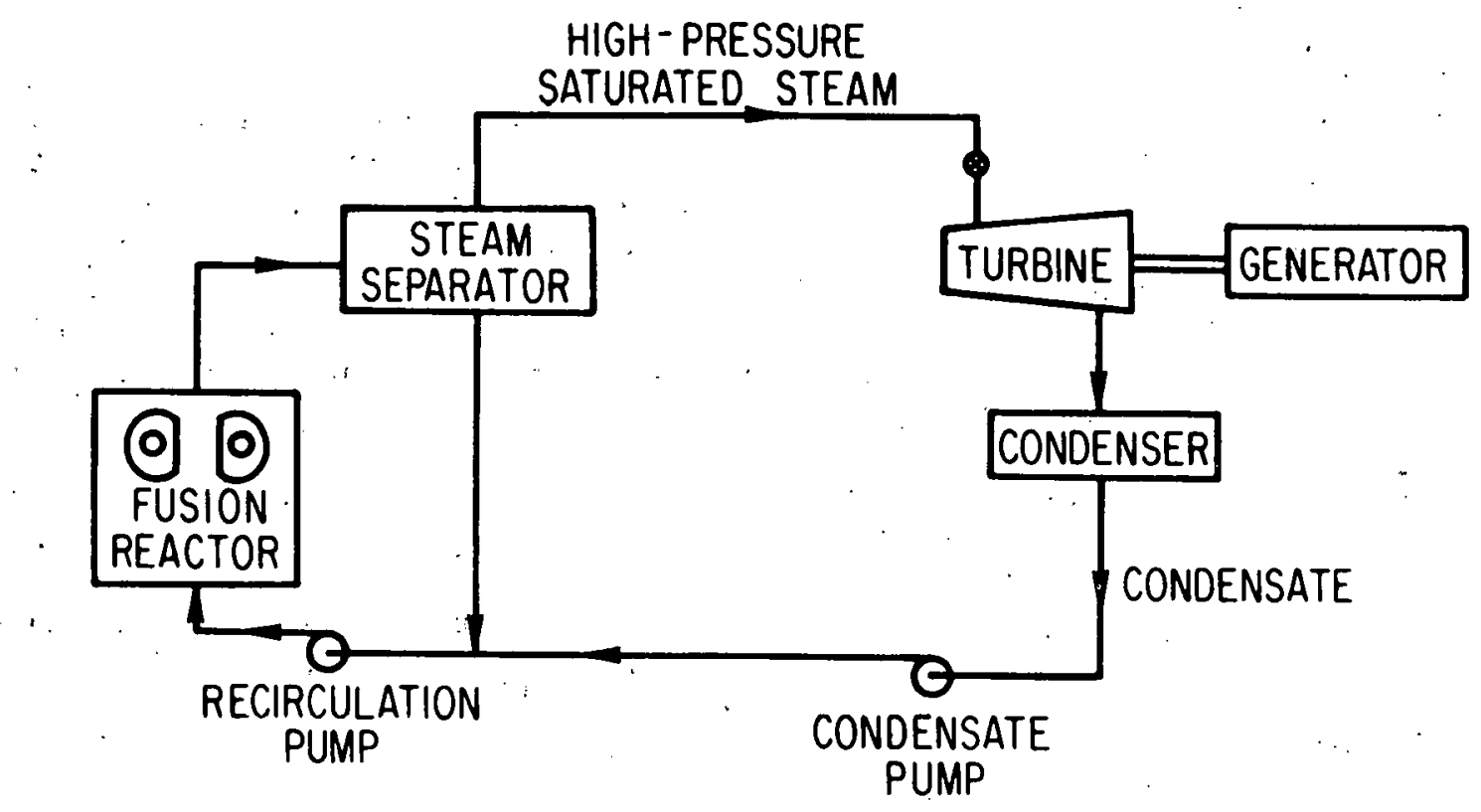

Fig. 3.13. Fusion Plant Concept

efficlency would thus be $31.5 \%$. This concept would use an estimated 3-4 $\mathrm{kg} /$ day of deuterium and $4-6 \mathrm{~kg} /$ day of tritium during normal operation.

The plant parameters, including plant availability, site size, land and water use, and costs are critically dependent on a still unproven ability to confine the fusion plasma. Any estimate of these at this time is thus little more than conjecture and cannot even be qualified by reasonable boundaries of uncertainty at this time. The final assessment will attempt to provide referenceable cost data.

\subsection{COST CHARACTERIZATIONS}

A comparative assessment of the electric generation costs for the SPS and"alternative technologies requires that each of the system's cost' components be characterized on a consistent and normalized basis. Unfortunately, technology cost estimates from previous assessment efforts were usually developed under assumptions that differed from study to study and are inconsistent with the characteristics assumed for the nominal reference. systems in this assessment. Thus, the remainder of this section quantitatively documents the procedure used to derive a set of consistent capital and operation and maintenance $(O \& M)$ costs for the SPS and alternative technologies.

For each technology, costs from the original data source are displayed, and it is then shown how these costs are adjusted to be consistent 
with the nominal reference system technology characteristics such as plant capacity and overall efficiency. Where the original data present estimated costs in other than 1978 dollars, these are normalized to 1978 dollars by application of appropriate escalation factors.

The development presented in this section results in baseline point estimates assuming each technology is constructed to come on 1 ine in 1978 and is financed totally in 1978 dollars. This is the starting point for the analysis and assessment presented in the next section (Sec. 4.1) where these 1978 point estimates are adjusted to reflect systems coming on line in the year 2000. Also in the following section, these costs are analyzed in terms of their potential uncertainties in the 2000 time frame by assigning a pessimistic upper range to the year-2000 base costs. Subsequent analysis is then based on these cost ranges.

As previously mentioned, construction costs for each of the nominal reference systems* were developed on a consistent basis by adjusting published data to a common set of rules and assumptions. Thus, all costs make similar assumptions about the owner's costs, contingencies, and allowances for funds used during construction. The primary source of data for the coal and nuclear systems was the Energy Economic Data Base (EEDB) 18 compiled and updated for DOE by United Engineers and Constructors. The General Electric study for EPRI ${ }^{9}$ and the SPS concept definition studies $2,5,6$ were used for input cost data on terrestrial photovaltaic and SPS systems, respectively. SPS costs represent NASA contractor estimates as costs for the SPS reference sys'tem described in reference 2 are not fully documented at this time.

In several cases the available cost estimates were for plant sizes and heat rates (efficlencies) different from those selected for the reference technologies. These were adjusted by power factors commonly used in electric utility cost estimation. A construction cost that excludes contingencies, owner's costs, and interest during construction was thus derived. Where costs were in a different year's dollars, they were adjusted to $1 y / 8$ dollars by an appropriate escalation rate; SPS cost estimates, 5, 6 given in 1977 dollars were escalated to 1978 dollars. using an $8.0 \%$ escalation factor.

Table 3.11 shows the capital costs for 5-GWe satellite power systems as estimated by Boeing Aerospace Corporation ${ }^{5}$ and Kockweil International Corporation. 6 These costs include all components identified in the original estimates and are presented in 1977 dollars. Construction cost estimates were derived from these figures in the following manner:, first, the mass contingency and management and integration factors were removed from the totals shown. The remaining costs for the satellite, ground receiving station, space transportation, and space construction and support were taken to be the direct capital costs of the SPS systems. These total $\$ 10.045$ billion and $\$ 11.952$ billion for the Boeing and Rockwell designs, respectively, in 1977 dollars. Secondly, the management and integration factor was taken to

\footnotetext{
*As noted at the end of this section, this analysis does not include fusion technology because of the highly uncertain nature of its scientific feasibility and costs.
} 
be the indirect cost associated with each design. In 1977 dollars these costs are $\$ 421 \mathrm{million}$ for Boeing and $\$ 576 \mathrm{million}$ for Rockwell. And finally, each of the direct and indirect costs was escalated by $8.0 \%$ to represent 1978 dollar amounts. As noted above, contingencies, owner's costs, and interest during construction are not yet included in the construction costs; these are added later in this section.

Construction costs - were derived for each of the alternative technologies in a similar manner. Table 3.12 summarizes the construction costs for each of the systems before normalizing to the reference system capacities and efficiencies, and adjusting for the multi-unit combined-cycle facility.

The direct capital costs for the terrestrial photovoltaic system (TPV) were modified from the original estimate 9 to assure compatibility with the cell efficiencies assumed in the SPS system definitions. Solar cell efficiencies assumed in the Boeing and Rockwe11 designs are $17 \%$ and $20 \%$, respectively. These are assumed efficiencies without a protective

Table 3.11. Boeing and Rockwell Capital Cost Estimates for Construction of an Average 5-GWe Satellite Power Systeme

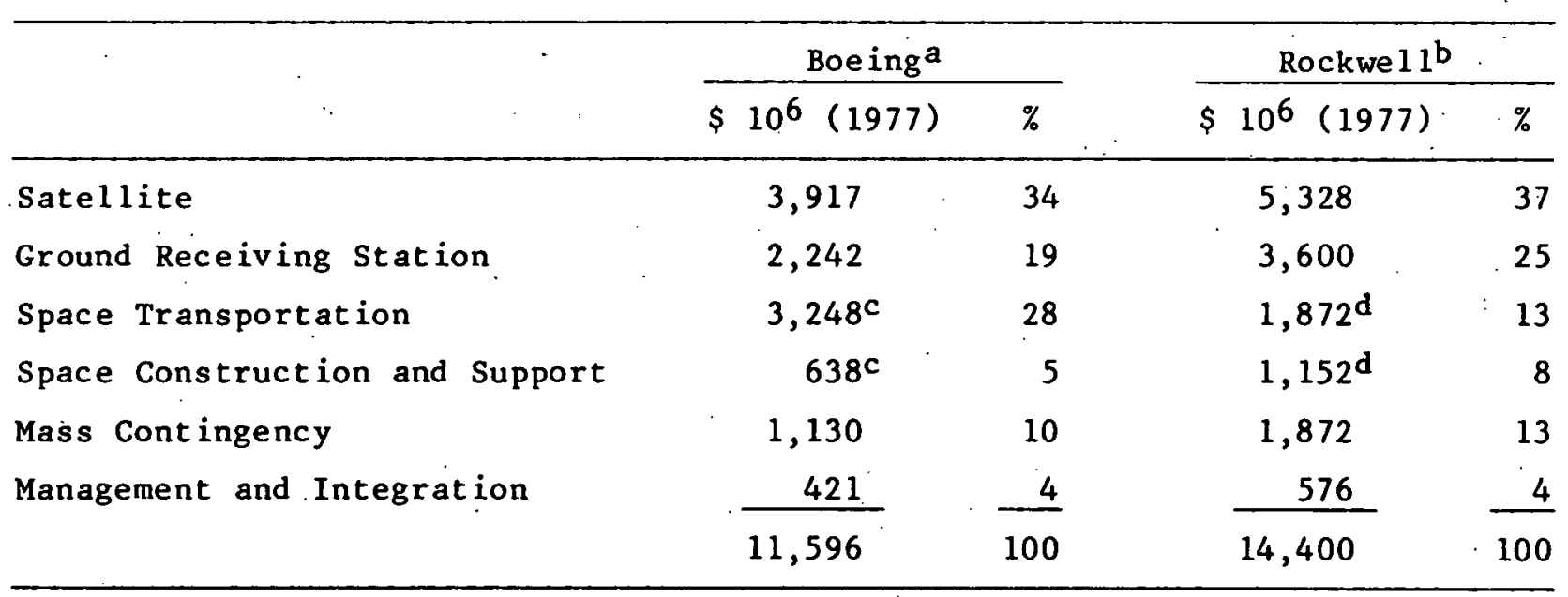

aFrom Ref. 5, p. 25; Interest During Construction of $\$ 825$ million omitted.

bFrom Ref. 6, p. 459; Interest During Construction not specified.

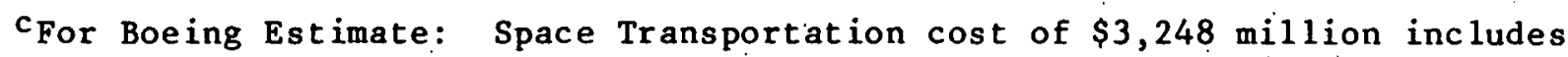
$\$ 1,802$ milition of direct costs plus $\$ 1,446$ million of capital recovery associated with capital shared by more than one SPS unit.

Space Construction and Support cost of $\$ 638$ million includes $\$ 218$ million of direct costs plus $\$ 420$ million capital recovery.

dFor Rockwell Estimate: Direct and capital recovery components not specified; data assumed to be compatible with Boeing estimates.

esPS capital costs represent NASA contractor estimates. SPS Reference System costs are not currently available but shall be included for subsequent analysis in the Final SPS Comparative Assessment. 
Table 3.12. Construction Cost Summary: SPS. and Alternative Technologies ( $\$ 10^{6}$, Jan. 1978)

\begin{tabular}{|c|c|c|c|c|c|c|c|}
\hline \multirow[b]{3}{*}{ Cost } & \multirow[b]{3}{*}{$\mathrm{LWR}^{\mathrm{a}}$} & \multicolumn{2}{|c|}{ Coal $^{a}$} & \multirow[b]{3}{*}{ LMFBR $^{a}$} & \multirow[b]{3}{*}{$T P V^{b}$} & \multirow{2}{*}{\multicolumn{2}{|c|}{ SPSC $^{C}$}} \\
\hline & & \multirow{2}{*}{$\begin{array}{l}\text { High } \\
\text { Sulfur }\end{array}$} & \multirow{2}{*}{$\begin{array}{c}\text { Comb ined } \\
\text { Cycle }\end{array}$} & & & & \\
\hline & & & & & & Boeing & Rockwe 11 \\
\hline Capacity (MWe) & 1,139 & 1,232 & 630 & 1,390 & 200 & 5,000 & 5,000 \\
\hline Direct Cost & 470.7 & 459.5 & 303.0 & 736.6 & .139 .3 & 10,850 & 12,910 \\
\hline Indirect Cost & 197.6 & 94.6 & 69.5 & 265.0 & 17.0 & 455 & 620 \\
\hline Construction Cost & 668.3 & $554: 1$ & 372.5 & $1,001.6$ & 156.3 & 11,305 & 13,530 \\
\hline
\end{tabular}

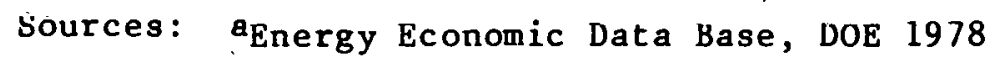

$\mathrm{b}_{\text {Ref. } 9 \text {. }}$

$c_{\text {Refs. }} 5$ and 6 .

glass cover that would be required in a terrestrial installation. The use of a protective glass cover would reduce the solar array efficiency by approximately $2 \%$. In estimating the TPV direct costs, it was assumed that the solar array efficiency is $15 \%$-- comparable to the Boeing estimate of $17 \% 1$ less $2 \%$ for a protective glass cover. Thus, since the solar array costs in the EPRI estimate 9 assumed $12 \%$-efficient solar arrays, the direct cost estimate given there was reduced by the ratio of efficiency, $12 \% / 15 \%$, or 0.80 , to account for the smaller area of cells that would be needed. Only the direct costs associated with the solar array were modified; direct costs for building, power conditioning, and electrical equipment, as well as all indirect costs, were left unchanged.

Direct and indirect costa shown for the LWR and high-sulfur coal options have been adjusted from the original estimate for differences in net plant rates (net conversion efficiencies) assumed in the Energy Economic Data Base and the reference systems previously characterized. A ratio of heat rates raised to an appropriate power* was used to make these cost adjustments. This practice is similar to the power ratio-exponent cost estimating technique* commonly used in the electric utility industry.

Where necessary, direct and indirect costs were normalized to the nominal capacities assumed for the alternative technology reference systems. SPS costs were assumed to lie halfway between the Boeing and Rockwell estimates. The terrestrial photovoltaic system costs needed no normalization because the reference system and original costs were each defined for a 200MWe system. Costs for the high-sulfur coal system, light water reactor, and LMFBR were normalized to 1,250 MWe by using the power ratio-exponent estimating technique.* The combined-cycle facility is assumed to be composed of

$$
\begin{aligned}
& { }^{*} \text { Cost } B=\operatorname{Cos} t^{\prime} A \times\left(\frac{\text { Heat Rate } B}{\text { Heat Rate } A}\right) \alpha \\
& \text { where: } \alpha=0.45 \text { for Nuclear LWR } \\
& \text { Cost } B=\operatorname{Cost~A~} \times\left(\frac{\text { Power B }}{\text { Power A }}\right) \alpha \\
& \alpha=0.69 \text { for Coal } \\
& \alpha=0.69 \text { for LMFBR }
\end{aligned}
$$


two 630-MWe units. Here, the first unit costs were taken to be those indicated in Table 3.12; the second unit was estimated to cost $90 \%$ of the first because of cost reductions achievable through shared facilities.

Contingencies, owner's costs, and allowances for funds used during construction (interest during construction) were then added to the normalized direct and indirect costs. These are shown in Table 3.13. Contingency estimates of $7-8 \%$ are fairly typical for coal and nuclear power plants currently being built. The contingencies for more advanced technologies are somewhat higher due to the added difficulties in estimating the technology requirements. The $16 \%$ contingency applied to the SPS costs is slightly higher than the percentage cost contingencies derived in the Boeing and Rockwell estimates (see Table 3.11).

However, this value is less than the Rockwell contingency facter when expressed in 1978 dollars [i.e. from Table 3.11.,. Rockwe11 contingency equals $\$ 1872(1977) \times 1.08=\$ 2022(1978)]$.

Owner's costs include such special items as preconstruction, engineering, consultant, and site selection charges. These were estimated by United Engineers and Constructors ${ }^{4}$ and are applied to each technology on a consistent basis.

Interest during construction was applied as a simple $4 \%$ per annum rate on expended capital during the construction period. For simplicity, the construction cash flows were approximated by straight-line functions over the following durations: SPS, 3 yr; terrestrial photovoltaic, 3 yr; high-sulfur coal, $5 \mathrm{yr}$; combined-cycle, $5 \mathrm{yr}$; 1 ight water reactor, $7 \mathrm{yr}$; and LMFBR, 5.5 yr. The $4 \%$ interest rate applied is consistent with the constant dollar (exclusive of inflation) interest on short-term construction capital, as has historically prevailed.

Operation and maintenance (O\&M) costs were also developed on a consistent basis for each of the technologies.6,9,12,19-22 0\&M costs include staff costs, fixed and variable materials and supplies, environmental control operation costs, insurance, interim replacements, and decommissioning expenses. Shown in Table 3.14 are the first-year rosts for the nominal reference systems. Specific assumptions about the escalation of these costs over the life of the systems, as well as fuel cost projections, are discussed in the following section on cost comparisons.

Available data on SPS O\&M costs vary considerably. Data available from Boeing $12,19,20$ show O\&M costs for the satellite portion of the SPS system alone (exclusive of the rectenna $0 \& M$ costs) at $\$ 118$ million per year, or $3 \mathrm{mills} / \mathrm{kWh}$ for $5 \mathrm{GWe}$ at a $90 \%$ capacity factor. On the other hand, Rockwe $11^{6}$ estimates annual O\&M costs at $\$ 6 \operatorname{lin}$ million per ycar or 16.7 mills/kWh for the entire 5-GWe SPS. A detailed review of the respective O\&M cost estimates indicates that the Rockwell figure represents a more comprehensive treatment of the subject and provides a more credible estimate of these costs. Thus the Rockwell estimates were used in the analysis.

The Rockwell estimates were, however, adjusted to an equivalent basis with the uther technologies. The Rockwell original estimate has the following components : 


\begin{tabular}{|c|c|}
\hline Cost Component & $\begin{array}{r}\text { Cost } \\
\left(\$ 10^{6}\right) \\
\end{array}$ \\
\hline $\begin{array}{l}\text { Management \& Integration } \\
\text { Ground Receiving Station } \\
\text { Satellite } \\
\text { Space Transportation } \\
\text { Mass Contingency }\end{array}$ & $\begin{array}{r}92 \\
79 \\
205 \\
198 \\
86 \\
\end{array}$ \\
\hline Total & 660 \\
\hline
\end{tabular}

First, because none of the other $0 \& M$ costs has a contingency factor; the $\$ 86$ million was removed from the total, leaving $\$ 574$ million. Then, the satellite and space transportation components were taken as being highly capital intensive and were categorized as interim replacements or capital for the purposes of Table 3.14. Also, the management and integration and ground recciving station ronts wpre assumed to be labor intensive, with lesser amounts of materials and supplies. These were taken as personnel, materials, supplies, and general administrative costs for Table 3.14. Finally, these costs were escalated by $8 \%$ to correct from 1977 dollars to 1978 dollars:

\section{Rockwel1 Estimate $\left(\$ 10^{6}\right)$}

Mgmt . \& Int.

Grud. Receiving Stn.

Satellite

Space Transportation
$92\}$

79 \}

205)
Table 3.14 Estimate $\left(\$ 10^{6}\right)$

\begin{tabular}{|c|c|}
\hline $\begin{array}{l}\text { Personnel, Materials, } \\
\text { Gen. Admin. }\end{array}$ & $171 \times 1.08=185$ \\
\hline $\begin{array}{l}\text { Interim Replacements } \\
\text { or Capital }\end{array}$ & $403 \times 1.08=4.35$ \\
\hline
\end{tabular}

Total

Capital, $0 \& M$, and fuel costs for the fuslon technology have hot been shown. These have been estimated by the University of Wisconsin 17 lo be $\$ 2,050$ per $\mathrm{kW}, \$ 23$ million per year, and $\$ 450,000$ per year, respectively, for a 660-MWe facility with an $80 \%$ capacity factor. Although these costs place fusion within competitive limits of current power generation technologies, they are highly uncertain and might more reasonably be considered as research and development goals, since plasma confinement has not yet been demonstrated.

The point estimates of capital and O\&M costs presented in Tables 3.13 and 3.14 represent those baseline costs that would be applicable if each of the systems were brought on line in 1978 and paid for in 1978 dollars. These values are further modified and analyzed in terms of potential cost uncertainties in the $2000-2030$ time frame in the fulluwisg section (4ee. 4.1) of this assessment. A wide range of fuel cost projections is also incorporated into the analysis in the following section. 
Table 3.13. Capital Costs for Major Alternatives ${ }^{a}$

\begin{tabular}{|c|c|c|c|c|c|c|}
\hline Cost Factor : & $\mathrm{H}-\mathrm{S} \mathrm{Coal}^{\mathrm{b}}$ & LWR & $\mathrm{CG} / \mathrm{CC}^{\mathrm{c}}$ & LMFBR & TPV & $\operatorname{SPS}^{\mathrm{d}}$ \\
\hline Power (MWe) & 1,250 & 1,250 & $2 \times 630$ & 1,250 & 200 & 5,000 \\
\hline \multicolumn{7}{|l|}{$\begin{array}{l}\text { Capital } \text { Cost } \\
\left(\$ 10^{6}, 1978\right)\end{array}$} \\
\hline Direct & 464 & 491 & 576 & 692 & 139 & 11,880 \\
\hline Ind irect & 96 & 206 & 133 & 239 & 17 & $540^{\mathrm{h}}$ \\
\hline Cont ingenc $\mathrm{y}^{\mathrm{e}}$ & 40 & 56 & 64 & 102 & 20 & 1,980 \\
\hline Base Cost & 600 & 7,53 & 773 & 1,033 & 176 & 14,400 \\
\hline Owner's Cost $f$ & 55 & 70 & 70 & 90 & 18 & 490 \\
\hline IDCG & 65 & 115 & 84 & 157 & 12 & 890 \\
\hline Total & 720 & 938 & 927 & 1,280 & 206 & 15,780 \\
\hline Unit Costs $(\$ / \mathrm{kW})$ & 580 & 750 & 740 & 1,020 & 1,030 & 3,160 \\
\hline Annual Heat Rate & & & & & & \\
\hline$(\mathrm{kJ} / \mathrm{kWh})$ & 10,454 & 10,982 & 9,610 & 10,032 & $\mathrm{NA}^{\mathrm{i}}$ & $\mathrm{NA}^{\mathrm{i}}$ \\
\hline
\end{tabular}

a Magnetic confinement fusion excluded due to a lack of technical definition of the fusion power plant.

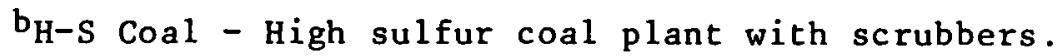

$\mathrm{c}_{\mathrm{CG}} \mathrm{CC}$ - Combined cycle with a coal gasifier.

dSPS - Satellite Power System - Based on average of Rockwell \& Boeing cost data.

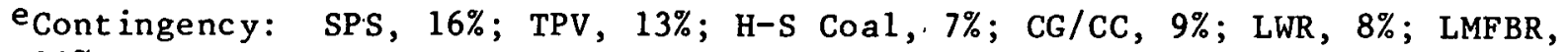
$11 \%$.

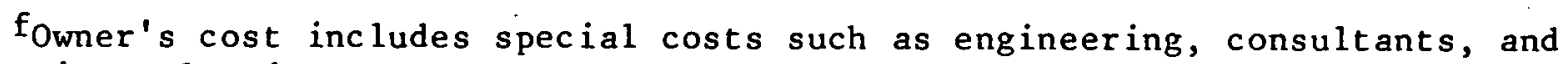
site selection.

IDC: Total Interest During Construction -- SPS, $6 \% ; \mathrm{TPV}, 6 \% ; \mathrm{H}-\mathrm{S}$ Coal, $10 \%$; CG/CC, $10 \%$; LWR, $14 \%$; LMFBR, $11 \%$. There is a simple $4 \%$ per annum rate on expended capital before initial operation; cash flow is assumed to be linear.

hSPS indirect cost requirements are low because many "typical" indirect items are included in the direct cost category.

iSPS has a six month construction schedule compared to longer times for coal and nuclear. 
Table 3.14. Annual Operation and Maintenance Costs

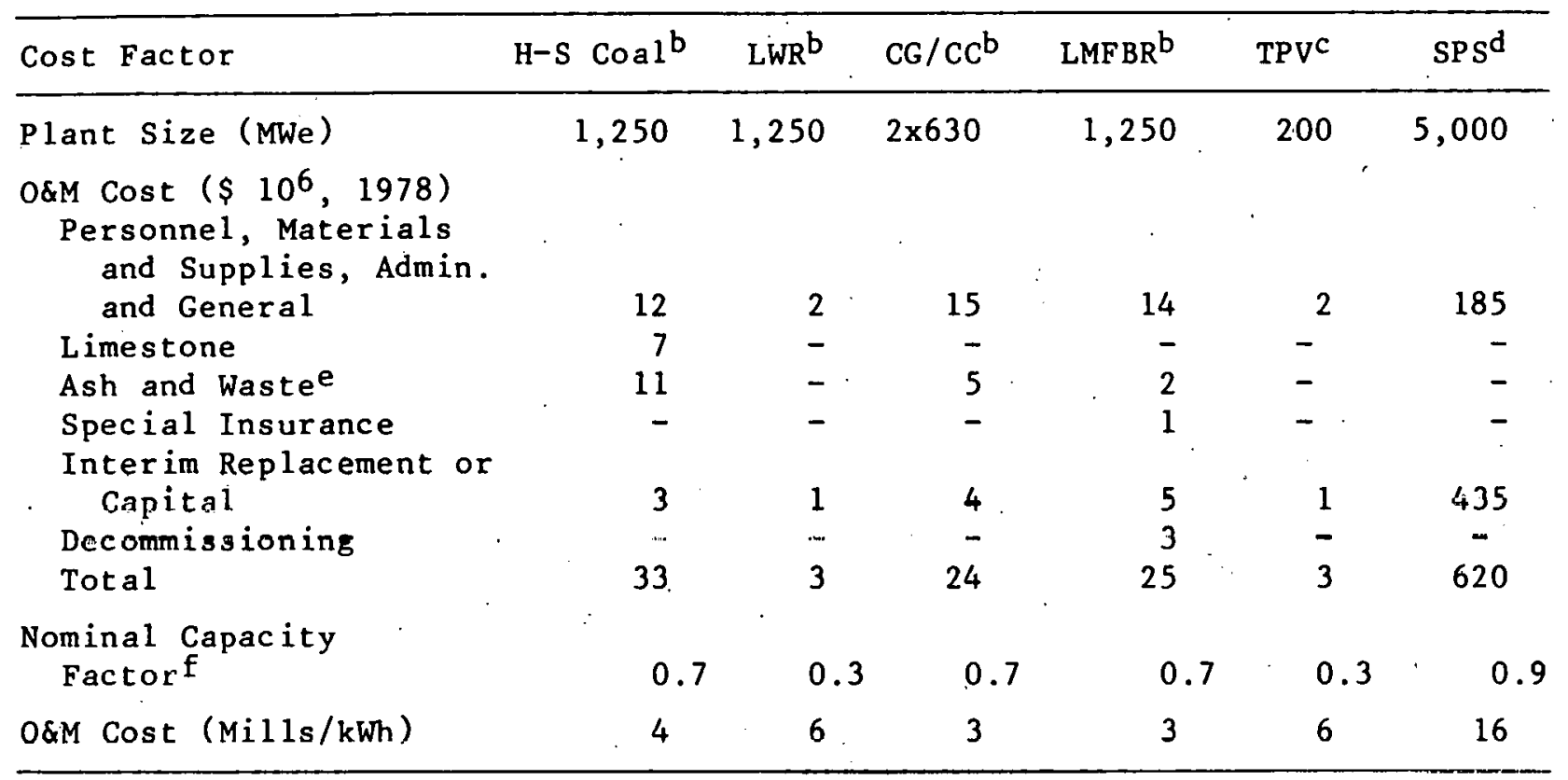

aMagnetic confinement excluded due to lack of cost data.

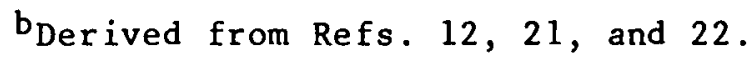

${ }^{c}$ Derived from Ref. 9.

$\mathrm{d}$ These costs have recently been revised due to an initial misallocation by Rockwell of capital investment costs to operation and maintenance.

e Does not include spent fuel and its fission products which are included in the fuel costs for LWR and LMFBR.

fCapacity factor is the ratio of the average load on a machine for the period of time considered (usually one year) to the rating of the machine. For large, baseload electric generation units, the capacity factor may approach the unit's availability factor, which is the ratio of time a generating unit is ready for or in service to the total time under consideration. 
4 ISSUE COMPARISONS

\subsection{COST AND PERFORMANCE}

\subsubsection{Issue Description and Analytic Approach}

The comparison of projected energy costs for technology options is a principal consideration in the selection of programs for further research and development. Cost analyses can be delineated in terms of key factors or issues that define the major considerations in the comparison of alternatives. This cost comparison presents the issues in terms of the following questions:

1. How will the cost of energy from the SPS compare with the costs of energy from alternative technologies in the post-2000 era?

2. How will these comparative costs be influenced by various possible state-of-the-world conditions?

3. What are the ranges of uncertainties in these estimates?

4. What is the effect of the R\&D costs on the' comparison of the energy costs, and

5. Are regional cost considerations significant in the comparisons?

Because of the hypothesis that the SPS could be available for implementation by 2000, this assessment focuses primarily on technologies that could be viable at that time. The 1978 cost estimates are adjusted to reflect this consideration.

The second question listed above addresses the effects of future economic conditions on the comparison of energy costs. For example, the results of the analyses are dependent on whether fuel prices increase rapidly or slowly with time and on the levels to which these prices rise. For the prellminary results given here, the effect of possible future conditions has been accounted for by using a very large range of values. Subsequent analyses will treat variations in future conditions through the construction and application of separate scenarios that relate the state-of-the-world assumptions in an internally consistent manner to the cost and performance values used in the analysis.

Capital costs of technologies that have not yet been developed are highly uncertain and depend in part on the commitment made to, and the results of, future R\&D efforts. At this time the estimated capital cust range for the SPS is large. Significant uncertainties also exist in the projected cost of energy from current or conventional technologies. Consideration of factors that contribute to the range of estimated costs is necessary for a valid pairwise comparison of technologies, and these factors have been included in the following analysis and assessment.

The effect of assigning future $R \& D$ costs to energy produced by a new technology also needs to be estimated. The amount of R\&D expenditure, 
the discount rate, and the time from expenditure to energy production are important components in the cost of the SPS compared with other alternatives. In general, the ranges of these component values assumed in this study do not significantly affect the direct energy costs of the SPS.

The analysis addresses technologies and their costs at a national level, because of the wide variations in costs that can exist in future technologies on even a "national average" basis. Furthermore, the regional differences in technology costs may be significant. Coal, for example, is an economically better energy source in some regions than in others. Although the SPS may be able to serve any region, it may have distinct cost disadvantages in some regions because of possible siting difficulties or power transmission costs.

Belected tcchnologies ware chararterized to provide consistent information for the overall comparisons with the SPS; the cost and performance analysis included five of these (coal, light water reactor, cumbilled lycle, breeder reactor and terrestrial photovoltaics; data on fusion for this comparison were not available at the time of this study). Two main claeses of analysis were made: (1) the individual technology calculations that did not include electric utility system effects and (2) the electrical generation system analyses that yielded total system costs with the various technologies added to the system. Because the terrestrial photovoltaic technology requires specific data to reflect the relationship between utility system load and the level of incident sunlight, a system analysis was not made for this technology. A separate photovoltaic overview analysis was made in which the space application was compared with the terrestrial application. The information for the analysis was based on an EPRI-sponsored study. 6

The preliminary cost and performance analysis described here comprises the following topics:

1. Individual technology comparisons,

2. Technology integration into electrical supply systems,

3. Cost and performance uncertainty,

4. A comparative overview of photovoltaic technology, and

5. Observations.

\subsubsection{Individual Technology Comparisons}

The individual technology or the direci energy cusl cumparisons provide estimates of the range of energy costs for electrical, energy produced by the SPS in comparison to analogous costs for other baseload technologies. All technologies are treated consistently, and uncertainty is examined in terms of ranges of possible future costs. To calculate levelized life-cycle costs, we used a constant-dollar revenue requirement method similar to the approach recommended by the Electric Power Research Institute (EPRI) for the analysis of generation costs of alternative technologies. 21 . Revenue requirements are determined from the expenses that must be covered to compensate the electrical energy producer for all costs and expenditures. A brief discussion of important assumptions and considerations follows; details of the methodology are provided in the EPRI report. 21 
Annual revenue requirements for an investment will normally vary from year-to-year over the life of the investment, but as a means of developing a single overall cost metric, the varying annual revenue requirements are converted to an equivalent stream of constant. (levelized) annual revenue requirements. Equivalency is established by equating the present worth of the

- varying annual revenue requirements stream with the present worth of the constant annual revenue requirements stream.

A discount rate consistent with financial assumptions is needed for the present worth and levelizing calculations. Most electric utilities use their own weighted average cost of capital as the discount rate for making these calculations. The weighted average cost of capital is composed of the appropriate fractions of preferred stock, common stock, and bonds inultiplied by the corresponding rates of return required in the marketplace.

In general, observed market rates of return reflect the investor's expectation of future general inflation plus some premium known as a "real" rate of return. The GNP deflator was used to estimate the his.toric inflation and to adjust the current dollar rates of return to obtain real rates of return. In the comparative analyses, annual and levelized revenue requirements were calculated in inflation-free or "constant" dollars. A 1978 dollar value was used as the constant dollar basis. Hence, only the "real" part of the discount rate should be used. Future prices of goods were expressed in the 1978 values, and increases higher than general inflation were added to these prices.

Financial Assumptions and Data

Base capital structure and econonic assumptions typical of privatelyowned utilities are used in the analysis and are summarized in Table 4.1. Variations in base capital structure and interest rates were examined as part of the analysis. With reasonable variations, they did not significantly affect the relative ranking or cost differential of technologies.* No investment tax credits were applied in this analysis because these politically determined incentives have had a history of frequent changes. Current regulatiuns ate cunsldered to be applicable only to the analysis of near-term projects.

\section{Capital Cost Estimates}

Capital costs for electric generation technologies to commense nperation in the year 2000 are highly uncertain. Accurate projections of costs in that era, even for technologies that are in commercial operation today, are nearly impossible. So many factors have historically affected the costs of electric generation that it is impossible to accurately predict capital

* These variations included higher real interest and return rates. of $5 \%, 5.5 \%$ and $10.2 \%$ for bonds, preferred stock and common stock, respectively. Debt to equity ratio variation was alsn examined at $70 \%$ bondc, $20 \%$ conmon stock, dul $10 \%$ preferred stock to bracket most utility financial configurations considered reasonable. 
Table 4.1. Capital Structure and Economic Assumptionsa

\begin{tabular}{lr}
\hline Debt Fraction & $50 \%$ \\
Common Stock Fraction & $35 \%$ \\
Preferred Stock Fraction & $15 \%$ \\
Real Bond (Debt) Interest & $2.0 \%$ \\
Real Return on Common Stock & $7.5 \%$ \\
Real Return on Preferred Stock & $2.5 \%$ \\
Effective Federal and State Income Tax Rate & $50 \%$ \\
Property Tax Rate & $2 \%$ \\
Investment Tax Credits & None \\
Rcal Discount Rate & $6 . \%$ \\
Real Annual Capital Charge Rate & $9.84 \%$ \\
Plant Book Life. & 30 years
\end{tabular}

Source: Ref. 2.1

all rates are real dollar values and thus exclude the effects of general inflation.

cost trends over the next twenty years or so. Even greater uncertainty surrounds the more advanced technologies such as the SPS and fusion (see Sec. 3.2.1) as a result of their early stäe of research and develupweul.

To account for this uncertainty in future costs, estimates were made of a possible base and "pessimistic" capital cost for each technology in the year 2000. The various rangeo woro derived from the point estimates nf 1.978 costs shown previously in Table 3.13. Historic escalation rates and published estimates of future cost trends and technologlcal changes were, analyzed to derive a base and pessimistic real escalation rate for each technology. The results of this procedure are summarized in lable 4.2. Obviously, the escalation rates and thus the range of capital costs. reflect somewhat judgmental values. Overall, however, the cost ranges are consistent with other estimates, and the final ratio of pessimistic to base cost 1 s consistent with the relative level of technological development.

The lower hounds of the capital coct ranges (base capital costs) were derived primarily through an analysis of the Handy-Whitman index 23 of public utility construction costs, which is widely used as a "bench-mark" index by the electric utility industry. It is here referred to as a bench-mark since it is derived not from actual project construction costs, but rather from a periodic sampling of a market basket of over 50 standard commodities and components used in conventional utility plant construction. The market basket contents have not been updated significantly in many years so that the index more closely tracks a lower bound of cost increases. That is, the HandyWhitman Index does not appropriately account for technological or regulatory cost increases, as is typified by the added cost of required sulfur removal or nuclear safety items imposed in recent years. 24 
Table 4.2. Estimated Range of Capital Costs for Year-2000 Technologiesa,b,c

\begin{tabular}{|c|c|c|c|c|c|c|}
\hline Cost & H-S Coal & LWR & $\mathrm{CG} / \mathrm{CC}$ & LMF BR & TPV & SPS \\
\hline Construction Costs, d 1978 & : & & & & - & \\
\hline $\begin{array}{l}1978 \text { costs, } \$(1978) / \mathrm{kW} \\
\text { Construction Costs, Base Year }-2000\end{array}$ & 580 & 750 & 740 & 1,020 & 1,030 & 3,160 \\
\hline $\begin{array}{l}\text { Compound real annual rate } \\
\text { of increase for } 1978 \text { to } 2000(\%) \text { e } \\
\text { Base year-2000 costs, } \$(1978) / \mathrm{kWh}^{\mathrm{h}} \\
\text { Construction Costs Pessimistic Year- } \\
2000\end{array}$ & $\begin{array}{r}1.50 \\
800\end{array}$ & $\begin{array}{r}2.00 \\
1,200\end{array}$ & $\begin{array}{r}1.50 \\
1,000\end{array}$ & $\begin{array}{r}2.00 \\
1,600\end{array}$ & $\begin{array}{l}0.75 \mathrm{f} \\
1,200\end{array}$ & $\begin{array}{l}0.40^{8} \\
3,400\end{array}$ \\
\hline $\begin{array}{l}\text { Compound real annual rate } \\
\text { of increase for } 1978 \text { to } 2000(\%)^{i} \\
\text { Unccrtainty multiplek } \\
\text { Combined multiple }\end{array}$ & $\begin{array}{r}5.00 \\
1.0 \\
2.9\end{array}$ & $\begin{array}{r}6.00 \\
1.0 \\
3.6\end{array}$ & $\begin{array}{r}5.00 \\
1.3 \\
3.7\end{array}$ & $\begin{array}{r}6.00 \\
1.3 \\
4.6\end{array}$ & $\begin{array}{l}\mathrm{NA}^{\mathrm{j}} \\
4.0 \\
4.0\end{array}$ & $\begin{array}{l}\mathrm{NA} \\
5.0 \\
5.0\end{array}$ \\
\hline $\begin{array}{l}\text { Pessimistic year-2000 cost, } \\
\quad \$(1978) / \mathrm{kW}^{\mathrm{m}}\end{array}$ & 1,600 & 2,800 & 2,700 & 4,700 & $4,200^{\circ}$ & 15,800 \\
\hline$\underline{\text { Ration }}^{n}$ & & & & & & \\
\hline Pessimistic/base & 2.0 & 2.3 & 2.7 & 2.9 & 3.5 & 4.6 \\
\hline
\end{tabular}

a See text for complete discussion of factors.

$\mathrm{b}_{\mathrm{Ail}}$ costs are expressed in 1978 dollars.

cMagnetic confinement fusion is excluded due to insufficient cost data.

dFrom Table 3.13.

eBased on an analysis of the historic trends of the Handy-Whitman Utility Construction Index.

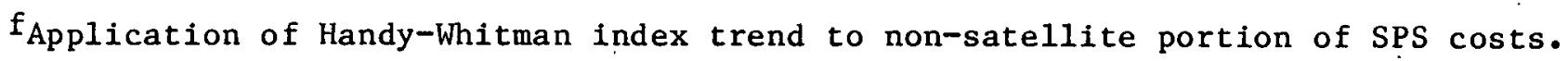
gApplication of Handy-Whitman index trend to non-photovoltalc portion of terrestrial photovaltalc syslew.

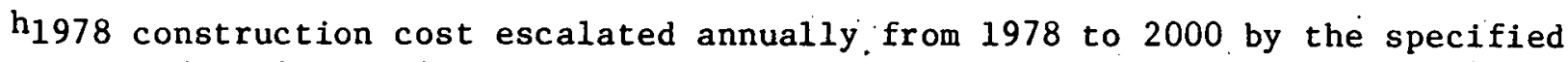
compound real annual rate of increase.

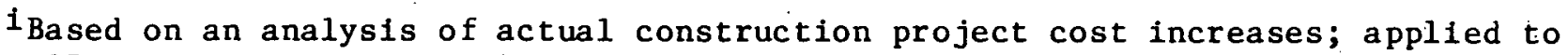
1978 construction costs.

jFactor not applied due to lack of historical data for these or similär systems.

kApplied to 1978 construction costs; see text for full discussion and underlying rationale.

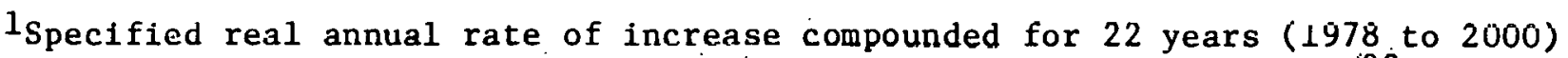
times the specifled uncertainly facter. Example for CG/CC: $(1.05)^{22} \mathrm{x} 1.3$ $=3.7$.

m1978 construction cost multiplied by the combined facter; roughly rounded to. nearest $\$ 100 / \mathrm{kW}$.

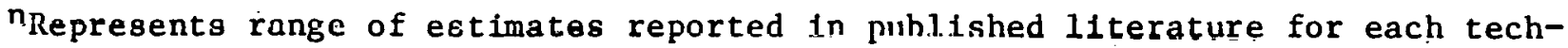
nology and does not represent uncertainties in the reference cost estimates. 
Over the 30-year period 1948-1978, the Handy-Whitman index has increased in real terms (relative to the GNP deflator) at an average compound rate of $1.5 \%$ per year. For the period 1948-1968, increases were about $1 \%$ per year, while for the period 1968-1978 increases averaged over $2 \%$ per year relative to the GNP deflator.

On this basis, reasonable lower bounds of real escalation above the 1978 costs shown in Table 3.13 were set at $2 \%$ per year for the nuclear systems (LWR and LMFBR) and $1.5 \%$ per year for the coal based systems (conventional coal and combined cycle). The nuclear system escalation was set slightly higher than that for coal as a result of possible additional safety requirements that may be prompted by recent incidents in the nuclear industry. These increases were compounded over the 22-year period 1978-2000, resulting in the base capital costs for the year 2000 shown in Table 4.2.

The lower bound escalatinn rates for the terrestrial photovoltaic and satelitite power systems are assumed to be approximately one half and one quarter, respectively, of the coal system rate of escalation. These lales were derived by applying $1.5 \%$ per year to the non-solar collector and nonspace portion of these systems. Only the costs of the rectenna site, for the SPS, and of the structural components of the terrestrial photovoltaic system were assumed to escalate at a real rate of $1.5 \%$ per year; the cost of the remainder of each system was assumed not to increase relative to inflation, due to a lack of historical data for these types of components. This assumption may underestimate the base cost of these solar energy systems.

Upper or pessimistic bounds of real escalation were selected on the basis of increases in construction costs over the past decade.25 Alrhnygh the available dala include estimates of actual construction project coste, these estimates are for a mix of plant sizes. However, the data indicate approximately a $10 \%$ per year real increase early on in the period, with the rate of increase tapering off to about $7 \%$ per year more recently. These rates of real escalation are due primarily to added safety regulations and environmental controls that have been imposed over this period; no time-related factors are included. The easing of these rates in more recent years is a result of attempts to consolidate and simplify the existing regulations and of a decrease in the escalation rate due to new regulations. Although these rates may ease even more in the future, it is also possible that they may continue to be quite substantial. Thus, continuing rates of $5 \%$ and $6 \%$ per year have been assumed for the coal and nuclear technologies. The rationale for selecting differential rates is the same as that for the lower escalation factors. No escalation rates were estimated for the solar energy systems because historical data are not available on these or similar systems. (Not including such a factor may well underestimate the possible upper bound of capital costs for these systems.)

Technological uncertainties also affect the cost ranges of the various alternatives. These effects are accounted for by the uncertainty factor shown in Table 4.2. For the most part, technological uncertainties for LWR and conventional coal systems are related to safety and environmental control components that are accounted for in the escalation rate previously discussed. Thus, the uncertainty factor is set equal to unity for these systems. 
A factor of 1.3 was applied to the combined cycle and LMFBR systems. For the combined cycle alternative, the gasifier elements make up the major technological uncertainty and also compose $30 \%$ of the nominal plant costs. It has been assumed that this component might increase in cost by as much as $100 \%$. For the LMFBR, two recent estimates provided by United Engineers and Constructors 25 show plant costs to vary by $30 \%$.

An uncertainty factor of 5.0 was applied to the 1978 cost of the SPS system. This value is equivalent to a factor of 4.6 applied to the year2000 base construction cost, and was estimated from various cost ranges recently documented in the SPS 1iterature.26-28 During 1976 and 1977, several independent study teams gave cost estimates. that ranged from a low $\$ 1400$ per kilowatt to a high $\$ 6000$ per kilowatt estimate. More recent point estimates by Boeing 5 and Rockwe $11^{6}$ resemble those presented in Table 3.13 of this assessment.

A recent ECON report 29 points out the sensitivity of the probability distribution of a cost to a change only in the solar cell assumptions of the Rockwell International design. 6 By a change in assumptions, the spread of a total cost distribution for the first theoretical unit was increased from a high/low ratio of 2 to one of 4 . In an article on sps costs, 30 Glaser discusses the SPS price tag and cost distributions. He states that the cost of producing the second 5-GW SPS may range from $\$ 8$ to $\$ 35$ billion, with a median cost of $\$ 14$ billion.

Little: information is available from which a possible range of costs for the terrestrial photovoltaic system can be derived. A reasonable assumption, however, is that this cost range should lie somewhere between the combined cycle or LMFBR range and that of the SPS. Since most of the uncertainty results from technical unknowns related to solar cell technology, and in light of ECON's results 29 concerning the possible impact of cell costs on SPS, a factor of 4.0 was assigned.

A combined factor, used to derive the high, year-2000 bounds of capital costs, was thus taken to be the product of the high multiplicative factor and the uncertainty factor for the appropriate technology option. The resultant combined factor was then multiplied by the 1978 base costs to arrive at the upper buund eslimale.

An examination of the ratio of high to low year-2000 capital cost estimates for the technologies resulting from these assumptions shows a reasonable consistency with the level of current knowledge and state of technological development apparent for each. This ratio varies from a value of 2.0 for conventional coal systems to come on line in the year 2000 , to 4.6 for the SPS in the same period. Table 4.3 summarizes the year-2000 capital cost ranges used in the analysis. Also shown are the operation and maintenance $(O \& M)$ costs and other technological performance parameters developed in Secs. 3.1 through 3.3 and used in the analysis.

\section{Operation and Maintenance Cost Estimates}

The operation and maintenance rnots shown in Tabled 4.3 are the same as those developed and presented in Sec. 3.3. Historically, electric 
Table 4.3. Summary of Capital Cost and Technology Assumptions for Year-2000 Technologies ${ }^{a}$

\begin{tabular}{lrrrrrr}
\hline Technology & Coal & LWR & CG/CC & LMFBR & TPV & SPS \\
\hline $\begin{array}{l}\text { Capital Cost, Base Year- } \\
\text { 2000, \$(1978)/kW }\end{array}$ & 800 & 1,200 & 1,000 & 1,600 & 1,200 & 3,400 \\
$\begin{array}{l}\text { Capital Cost, Pessimistic } \\
\text { Year-2000, \$(1978)/kW }\end{array}$ & 1,600 & 2,800 & 2,700 & 4,700 & 4,200 & 15,800 \\
Pessimistic/Low Ratio & 2.0 & 2.3 & 2.7 & 2.9 & 3.5 & 4.6 \\
$\begin{array}{l}\text { O\&M Costs, } \\
\text { millo (1978)/kWh }\end{array}$ & 4 & 3 & 3 & 3 & 6 & 16 \\
$\begin{array}{l}\text { Capacity, MWe } \\
\text { Capactty Factor }\end{array}$ & 1,250 & 1,250 & 1,750 & 1,250 & 200 & 5,000 \\
Heat Rate, kJ/kWh & 0.70 & 0.70 & 0.70 & 0.70 & 0.30 & 0.90 \\
\hline
\end{tabular}

aMagnetic confinement fusion excluded due to lack of cost data.

utility $0 \& M$ costs have been increasing at a rate slightly less than $1 \%$ per year, or at about the historic rate of increase in real general labor costs. Although many factors may tend to influence future O\&M costs, no attempt has been made to factor these cost variations into this preliminary analysis. In particular, the cost of interim replacements and component failure rates could have a sizable effect on ultimate O\&M costs. The values used here assume interim replacements at costs consistent with the lower bound estimate of each technology's. capital costs, although higher original capital costs would surely affect the cost of subsequent capital replacements. Decommissioning costs, particularly for the nuclear technologies, could have a major effect on total plant O\&M. However, because of the relatively small magnitude of O\&M in relation to the capital and fuel components of generating costs, these variations would have little effect on the outcome of the preliminary cost comparisons. Thus, for the purpose of this analysis, all O\&M costs are assumed not to increase relative to inflation in the 22-year period, 1978 to 2000. After 2000 , O\&M costs, including labor and material components, are assumed to escalate at $1 \%$ above the general inflation rate. Again, these or other reasonable assumptions regarding $0 \& M$ costs do not significantly affect the outcome of the cost comparisons.

Cost Projections for Coal and Nuclear Fuel

Ranges of delivered fuel costs have been assumed in order to reflect a wide range of possible future economic conditions. The fuel price ranges shuwn in Fig. 4.1 are preliminary and have been selected to portray a conservatively wide range of possible future prices. The high range shown is significantly higher than most current published projections of future fuel prices. In subsequent investigations for the Final Comparative Assessment, 
fuel prices consistent with alternative macroeconomic and supply/demand scenarios will be derived.

Recent fuel prices have been strongly influenced by the oil shortage and the pricing policies of OPEC. The concomitant coal price behavior provides little basis for any reliable future estimate. The study of price behavior over a longer term shows that since 1960 the average price of coal burned by utilities increased at a rate of about $3 \%$ per year in real terms. 31 Almost all of this increase, however, occurred after the oil embargo of 19.73 . The coal rate of increase in real value from 1973 thru 1977 corresponded to about $15 \%$ per year ${ }^{32}$ and part of the increase was a result of tighter mining and environmental regulations. Prices used in this analysis started with a 1978 price of $\$ 0.95$ per million $k J$ on a nationwide basis. Corresponding regional prices ranged from about $\$ 1.4$ per million $\mathrm{kJ}$ in the New England area to $\$ 0.5$ per million $\mathrm{kJ}$, in the Mountain and West South Central areas.33

The range of prices was derived for the year 2000 by assuming a $5 \%$ and a $3 \%$ compound real escalation rate from 1978 until 2000 . This results in a year-2000 cost range of $\$ 1.8-\$ 2.75 / \mathrm{milli}$ ion $\mathrm{kJ}$. We assumed that price increases would be more moderate after the year 2000. The high coal price was assumed to increase at $3 \%$ per year, which yields $\$ 6.45 / \mathrm{million} \mathrm{kJ}$ by 2030 , whereas the low price for 2000 was increased at $1 \%$ per year, which yields $\$ 2.4 / \mathrm{million} \mathrm{kJ}$ by 2030 . The lower escalation rate of $1 \%$ per year is consistent with long-term projections of market equilibrium coal prices as modeled by various supply/demand studies.34,35 The final range covers the possibility of including the complete effect of an $\$ 80$ billion rail transportation capital improvement in the delivered price of utility coal. Such

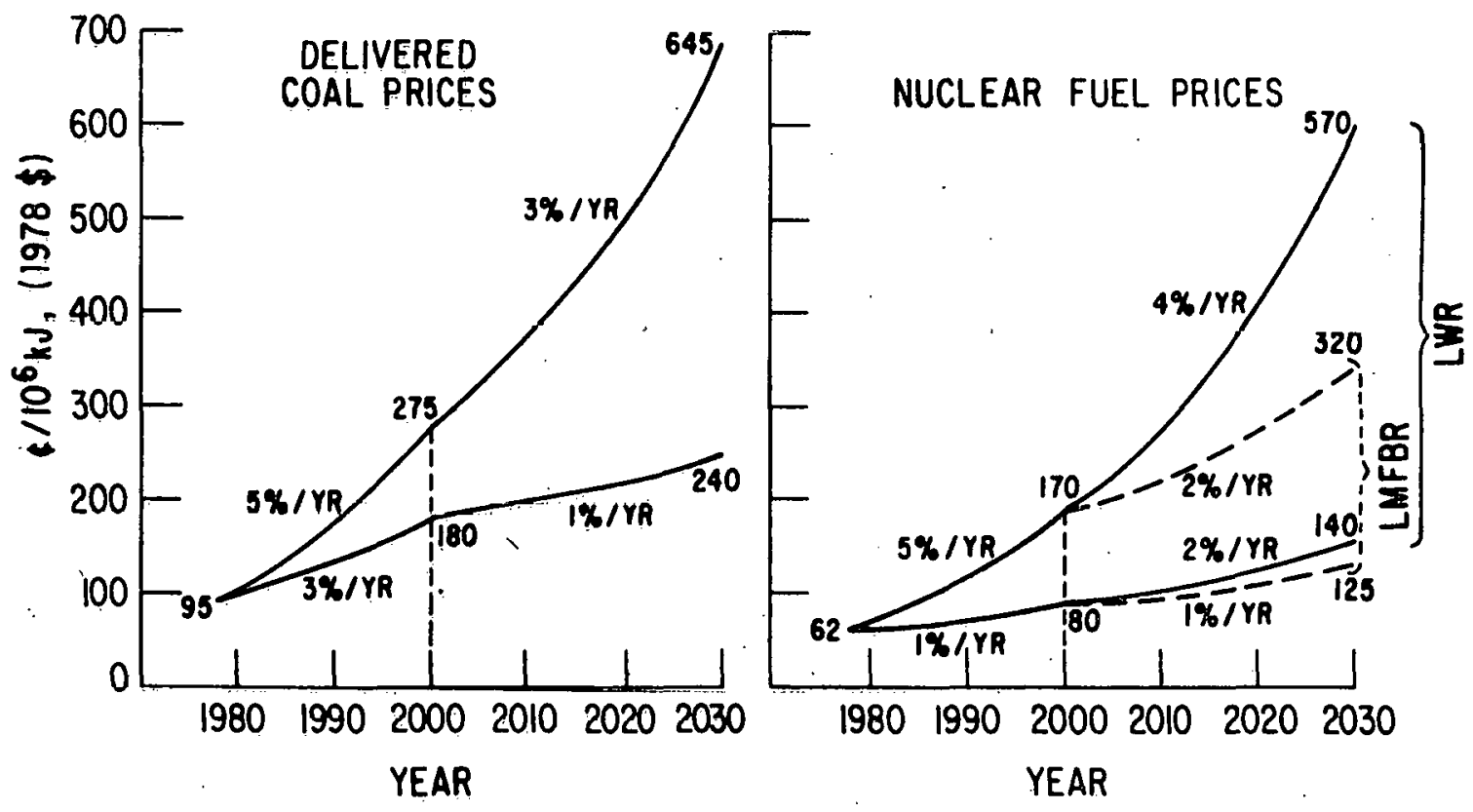

Fig. 4.1. Assumed Fuel Costs 
an investment would add about $\$ 0.7 / \mathrm{million} \mathrm{kJ}$ to the price of the $450 \mathrm{million}$ metric tons of atility coal currently burned by electric utilities in the United States each year.*

The total nuclear fuel cost includes the market price of $\mathrm{U}_{3} \mathrm{O}_{8}$ and the cost of the uranium enrichment process, which together come to nearly $80 \%$ of the total nuclear fuel cost. Like coal, the nuclear fuel costs have recently changed significantly. From 1970 to 1978 , the price of $\mathrm{U}_{3} \mathrm{O}_{8}$ increased in real terms from $\$ 26.45 / \mathrm{kg}$ to $\$ 37.50 / \mathrm{kg}$ or about $5 \%$ per year. During the same period, enrichment costs increased. from $\$ 43 /$ SWU** to $\$ 75 / \mathrm{SWU}$ or about $7 \%$ per year. 36 As a result, the price of nuclear fuel increased about $5.8 \%$ per year over the period to a 1978 price of $\$ 0.62 / \mathrm{million} \mathrm{kJ}$.

High and low nuclear fuel costs were assumed to follow, respectively, a $5 \%$ and $1 \%$ pes year rate of increase trom the current price to the year 2000 . The range of the LWR fuel costs would increase from a 1978 value of $\$ 0.62 /$ million $\mathrm{kJ}$ to $\$ 0.80-\$ 1.70 / \mathrm{million} \mathrm{kJ}$ in the year 2000 . In the suhsequent 30 years, the corresponding escalations are assumed to be $4 \%$ and $2 \%$. This would bring the LWR fuel costs to a range of $\$ 1.40$ to $\$ 5.70 / \mathrm{milli}$ ion $\mathrm{kJ}$ in 2030 . LMFBR fuel costs were assumed to be equal to LWR fuel cost.s in the year 2000 . After that time the LMFBR fuel cost is assumed to escalate at half the LWR fuel cost in the 2000-2030 period because of various cost savings that are inherent in the LMFBR fuel cycle. In 2030, LMFBR fuel costs would range from $\$ 1.25 / \mathrm{million} \mathrm{kJ}$ to $\$ 3.20 / \mathrm{million} \mathrm{kJ} .^{\dagger}$

\section{Comparisons}

Levelized revenue requirements for each of the alternative electric generation technologies are displayed in Table 4.4 and Fig. 4.2. Note that two casco arc shown füi: the SPS. The casc labeled "SPS" assumes a fully taxed ownership of the SPS satellite and ground rectenna statinn. The "SPS Low Tax" case, on the other hand, makes the assumption that only the rectenna investment is subject to federal income taxes and prnperty taxes. That in, no income $t a x$ is paid on revenues attributable to the space portion of the SPS investment ${ }^{\dagger f}$ nor are any international taxes or payments in lieu of taxes assessed against the satellite.

Several observations can be made from these results. First, under Lhe economic and technological assumptions made in this analysis, the fully taxed SPS appears to overlap and might be competitive with the alternatives in

*ERRI Technical Assessment Guide (P̈S-1201-SR) projects 2030 delivered coal pricca of $\$ 2$ to $\$ 2.4 / 10^{6}$ Bcu.

**SWU - separatory work unit, an aggregate measure of resources used in the enrichment process.

†EPRI Technical Assessment Guide (PS-1201-SR) projects nuclear fuel prices of about $\$ 1.10 / 10^{6}$ Btu.

${ }^{\dagger}{ }^{\prime}$ lectric utilities are taxed on income in excess of that necessary to recover their capital investment. This case assumes that the space satellite portion of the SPS investment is exempt from all taxes, thus eliminating revenue necessary to pay taxes. 
Table 4.4. Levelized Annual Generation Revenue Requirements (mills/kWh, 1978 dollars) for Operation Beginning in $2000^{\mathrm{a}}$

\begin{tabular}{|c|c|c|c|c|c|c|c|c|c|c|c|c|c|c|}
\hline \multirow{2}{*}{ Technology } & \multicolumn{2}{|r|}{ Coa! } & \multicolumn{2}{|c|}{ LWR } & \multicolumn{2}{|c|}{$\mathrm{CG} / \mathrm{CC}$} & \multicolumn{2}{|c|}{ LMFBR } & \multicolumn{2}{|c|}{ TPV } & & SPS & \multicolumn{2}{|c|}{ SPS } \\
\hline & Base & $\begin{array}{l}\text { Pessi- } \\
\text { mistic }\end{array}$ & Base & $\begin{array}{l}\text { Pessi- } \\
\text { mistic }\end{array}$ & Base & $\begin{array}{l}\text { Pessi- } \\
\text { mistic }\end{array}$ & Base & $\begin{array}{l}\text { Pessi- } \\
\text { mistic }\end{array}$ & Base & $\begin{array}{l}\text { Pessi- } \\
\text { mistic }\end{array}$ & Base & $\begin{array}{l}\text { Pessi- } \\
\text { mistic }\end{array}$ & Base & $\begin{array}{l}\text { Pessi- } \\
\text { mistic }\end{array}$ \\
\hline \multicolumn{15}{|l|}{ Capital } \\
\hline Capital Recovery & 8 & 16 & 12 & 28 & 10 & 27 & 16 & 47 & 28 & 112 & 26 & 123 & 26 & 123 \\
\hline Federal Taxes. & 3 & 6 & 5 & 12 & 4 & 11 & 7 & 20 & 12 & 47 & 11 & 51 & 3 & 13 \\
\hline \multicolumn{15}{|l|}{ Property or } \\
\hline International Taxes $c$ & 2 & 4 & 2 & 5 & 2 & 5 & 3 & 19 & 5 & 21 & 5 & 23 & 1 & 6 \\
\hline Total Capital & 13 & 26 & 19 & 45 & 16 & 43 & 26 & 46 & .45 & 180 & $42^{-}$ & 197 & 30 & 142 \\
\hline OFeration \& Maintenance ${ }^{d}$ & 5 & 5 & 3 & 3 & 3 & 3 & 4 & 4 & 6 & 12 & 18 & 18 & 18 & 18 \\
\hline $\begin{array}{l}\text { Fueld } \\
\text { Range of Revenue }\end{array}$ & 20 & 43 & 11 & 34 & 18 & 40 & 9 & 23 & - & - & - & - & - & - \\
\hline Requirement (rounded) & 40 & -75 & 35 & --80 & $40-$ & -85 & 40 & -100 & $51-$ & --192 & $60-$ & --215 & $50-$ & --160 \\
\hline
\end{tabular}

The base estimate is the sum of the base costs and the pessimistic estimate is the sum of the pessimistic costs; no distribution effects are included.

bFusion is not included because of a lack of cost data.

CInternational taxes applied to the satellite are assumed at the same rate as domestic property tax.

dable values are levelized costs over a 30-year lifetime of the facility; See Ref. 21. for a complete discussion and underlying theory. 


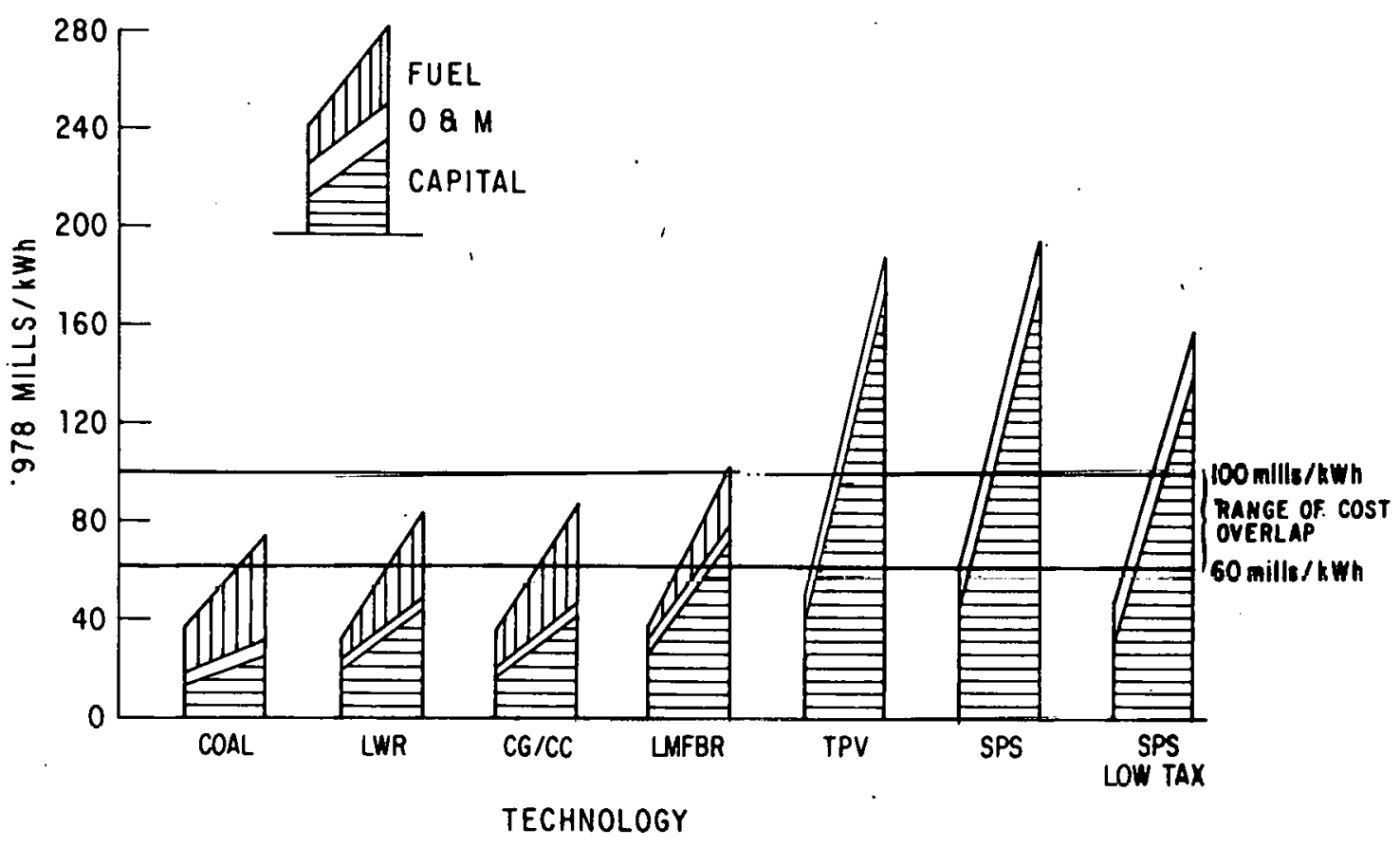

Fig. 4.2. Levelized Life-Cycle Costs

(Fusion Not Included Because of a Lack of Cost Data)

the range of 60-100 mills/kWh. Second, taxing only the earth-based portion of. the SPS system would change the range of SPS to $50-100 \mathrm{mills} / \mathrm{kWh}$. For both observations, the upper limit of the overlap is defined by the upper bound of the LMFBR technology. Each of the other coal and nuclear technologies has an upper bound that is 10-25 mills/kWh less than that of the LMFBR. Comparison of the SPS with these options thus narrows the competitive range significantly. However, some overlap in costs may still occur.

\subsubsection{Technology Integration into Electrical Supply Systems}

Analyoes have been made lu sliuw lie resulis of adding eicher sps or alternative generating technologies to an existing generating system. System calculations were only made for the LWR, LMFBR, and coal alternatives.

It is important to account for system integration effects in comparing alternative generating technologies. Analysis of technologies in isolation may not fully expose some of the problems assoclaced with the design and operating characteristics. System size, composition, and power demand factors can have significant effects on system performance and consequently on costs.

Utility system planning is ordinarily done on an integrated system basis because the equivalent capacities of any two technologies do not 
generally provide the same level of system reliability. Each generating technology has different operating characteristics that interact with those of other units and with system load characteristics to determine system per formance.

Reliability indices are used in this analysis to normalize various system configurations to equivalent performance characteristics. The normalized configurations are examined under a variety of cost assumptions to provide insight into tradeoffs between system reliability effects and cost impacts of system expansion alternatives.

System integration comparisons presented here treat only the performance and interactions of generating system components. The transmission system has not been included but has been left for possible consideration in a later and more complete analysis.

In addition to the uncertainties that arise from engineering problems and judgmental estimates are the uncertainties of future energy, economic, and regulatory conditions. Uncertainties in fuel prices, safety and control requirements, technology improvements, and long-term trends in costs of capital and labor must be recognized in comparisons of future generating technology alternatives. Several. sets of cost assumptions were used to examinc the implications of these uncertainties.

\subsubsection{Approach to Integration Analyses}

In order to provide consistent comparisons between SPS and other generating alternatives, system expansion patterns over an 18-year period were developed for each technology. These expansion plans describe the number and type of generating units added to the system in each year of the planning period.

Initially, the expansion patterns were constructed from several sets of expansion strategy guidelines and then normalized to the same level of system reliability. After the expansion patterns were normalized they were examined under a variety of cost assumptions that describe future trends in fuel, $0 \& M$, and capital costs as well as different escalation rates. Levelized costs were computed for each system and each sec of cundlliuls. Expansion of a 60-GWe-load system was analyzed where the expansion capacity is primarily SPS, or an equal mix of coal and nuclear light water reactor (LWR). The coal-LWR mix was designated as the base-case for this analysis.

The same initial system configuration is used as a starting point in each case. The initial system corresponds in size to a pool of several utilities and the mix of generating units is the result of assumed plant technology development up to and through the year 2000 .

Each case is uniquely described by a primary expansion pattern and fuel price projection, the details of which are displayed, respectively, in Tables 4.5 and 4.6. In all cases, the capital costs used are consistent with the base capital cost developed in Sec. 4.1.2, with the addition of oil peaking units. These costs are: 
Table 4.5. Installed Capacity

\begin{tabular}{|c|c|c|c|c|c|c|c|c|c|c|}
\hline \multirow[b]{2}{*}{$\begin{array}{c}\text { Primary } \\
\text { Expansion Pactern }\end{array}$} & \multicolumn{5}{|c|}{ Year 1} & \multicolumn{5}{|c|}{ Year 18} \\
\hline & $\begin{array}{c}\text { Nuclear } \\
(\%)\end{array}$ & $\begin{array}{r}\text { Coel } \\
(\%)\end{array}$ & Cil & $\begin{array}{l}\text { SPS } \\
(\%)\end{array}$ & $\begin{array}{l}\text { Total } \\
\text { (GWe) }\end{array}$ & $\begin{array}{c}\text { Nuclear } \\
(\%)\end{array}$ & $\begin{array}{r}\text { Coal } \\
(\%)\end{array}$ & $\begin{array}{l}0 i 1 \\
(\%)\end{array}$ & $\begin{array}{l}\text { SPS } \\
(\%)\end{array}$ & $\begin{array}{l}\text { Total } \\
\text { (GWe) }\end{array}$ \\
\hline Coa1-LWR & 22.4 & 67.0 & 10.6 & 0.0 & 66.9 & 28.7 & 60.8 & 10.5 & 0.0 & 117.6 \\
\hline SPS & 22.4 & 67.0 & 10.6 & 0.0 & 66.9 & 12.9 & 44.3 & 8.3 & 34.5 & 116.1 \\
\hline
\end{tabular}

Table 4.6. Fuel Price Escalations

\begin{tabular}{|c|c|c|c|c|c|c|c|}
\hline \multirow[b]{2}{*}{$\begin{array}{l}\text { Fuel Price } \\
\text { Projection }\end{array}$} & & \multicolumn{2}{|c|}{ Nuclear } & \multicolumn{2}{|l|}{ Coal } & \multicolumn{2}{|l|}{$0 i 1$} \\
\hline & & $\begin{array}{c}\text { Initial Price } \\
\left(\notin / 10^{6} \mathrm{~kJ}\right)\end{array}$ & $\begin{array}{c}\text { Escalation } \\
(\% / y r)\end{array}$ & $\begin{array}{l}\text { Initial Price } \\
\left(\notin / 10^{6} \mathrm{~kJ}\right)\end{array}$ & $\begin{array}{c}\text { Escalation } \\
(\% / y r)\end{array}$ & $\begin{array}{l}\text { Initial Price } \\
\left(\notin / 10^{6} \mathrm{~kJ}\right)\end{array}$ & $\begin{array}{c}\text { Escalation } \\
(\% / \mathrm{yr})\end{array}$ \\
\hline Zero & & 80 & 0 & 140 & 0 & 570 & 0 \\
\hline Low ${ }^{a}$ & . & 80 & 2 & 180 & $I$ & .570 & 1 \\
\hline Medium & & 140 & 3 & 240 & 2 & 570 & 2 \\
\hline $\mathrm{High}^{\mathrm{b}}$ & & 170 & 4 & 275 & 3 & 570 & 3 \\
\hline
\end{tabular}

a Identicai to low fuel price escalations used in direct energy cost comparison.

bIdentical to high Euel price es:alations used in direct energy cost comparison.

cyear 2000 prices in 1978 Jollars. 


$\begin{array}{lr}\text { Coal } & \$ 800 / \mathrm{kW} \\ \text { LWR } & \$ 1,200 / \mathrm{kW} \\ \text { SPS } & \$ 3,400 / \mathrm{kW} \\ \text { Oil } & \$ 200 / \mathrm{kW}\end{array}$

Capital costs were not escalated through time for consistency with the assumptions made in the direct energy cost comparison. Operation and maintenance $(O \& M)$ costs were set equal to the direct energy cost comparison assumptions and were also escalated at $1 \%$ per year except under the zero fuel price projection, in which zero escalation was assumed. All system expansions were assumed to begin in 2000, with the analysis running for 18 yeárs. All cost calculations involving present value or levelizing techniques were referenced to the year 2000, consistent with the economic assumptions made in the direct cost comparisons. Thus, under these conditions, it should be noted that cases employing low or high fuel price projections use assumptions identical to those used in the direct cost comparisons. The zero and medium fuel price projections assume slightly lower initial (year 2000) fuel prices and escalation rates.

In addition to the standard, or fully-taxed economic calculations, costs were also determined under the SPS low tax conditions, which assume no international or federal income tax levied against the satellite portion of the SPS investment; all other capital investment is fully taxed, as are all of the other technologies.

Results of Integration Analysis

Results of the utility integration analysis are presented in Figs. 4.3-4.6, and Tables 4.7 and 4.8. The figures show the annual total system generation costs for each of the expansion patterns under the fuel price. projections. Table 4.7 presents the system generation costs for the last year of the analysis, whereas Table 4.8 shows the 18-year levelized generating costs associated with the system expansions and the fuel cost projections.

Generally, the systems expanded with the SPS under fully taxed conditions exhibit relatively higher generation costs compared to expansions using coal and LWR technologies. In the cases analyzed, the system expansions with fully taxed SPS show year-18 annual generation costs that range from a high of $47 \%$ (SPS expansion, zero fuel escalation) to a low of $0.4 \%$ (SPS expansion, high fuel escalation) above the conventional technology expansion schemes. Likewise, levelized generation costs range from $26 \%$ to $4 \%$ above the conventional technology expanision schemes for the same cases. Only under the high fuel price projection. does the SPS technology show promise of becoming competitive with the conventional technologies. Examination of Fig. 4.6 indicates that the SPS expansion and high fuel costs would be equal Lo the coal-LWR expansion and high fuel costs in the year following the last year of the analysis. Levelized costs for this SPS expansion, however, would remain greater than the levelized cost for the coal-LWR expansion for many years because the SPS costs are higher in the early years, and the cost differences of later years are discounted more heavily in the present value calculations. 


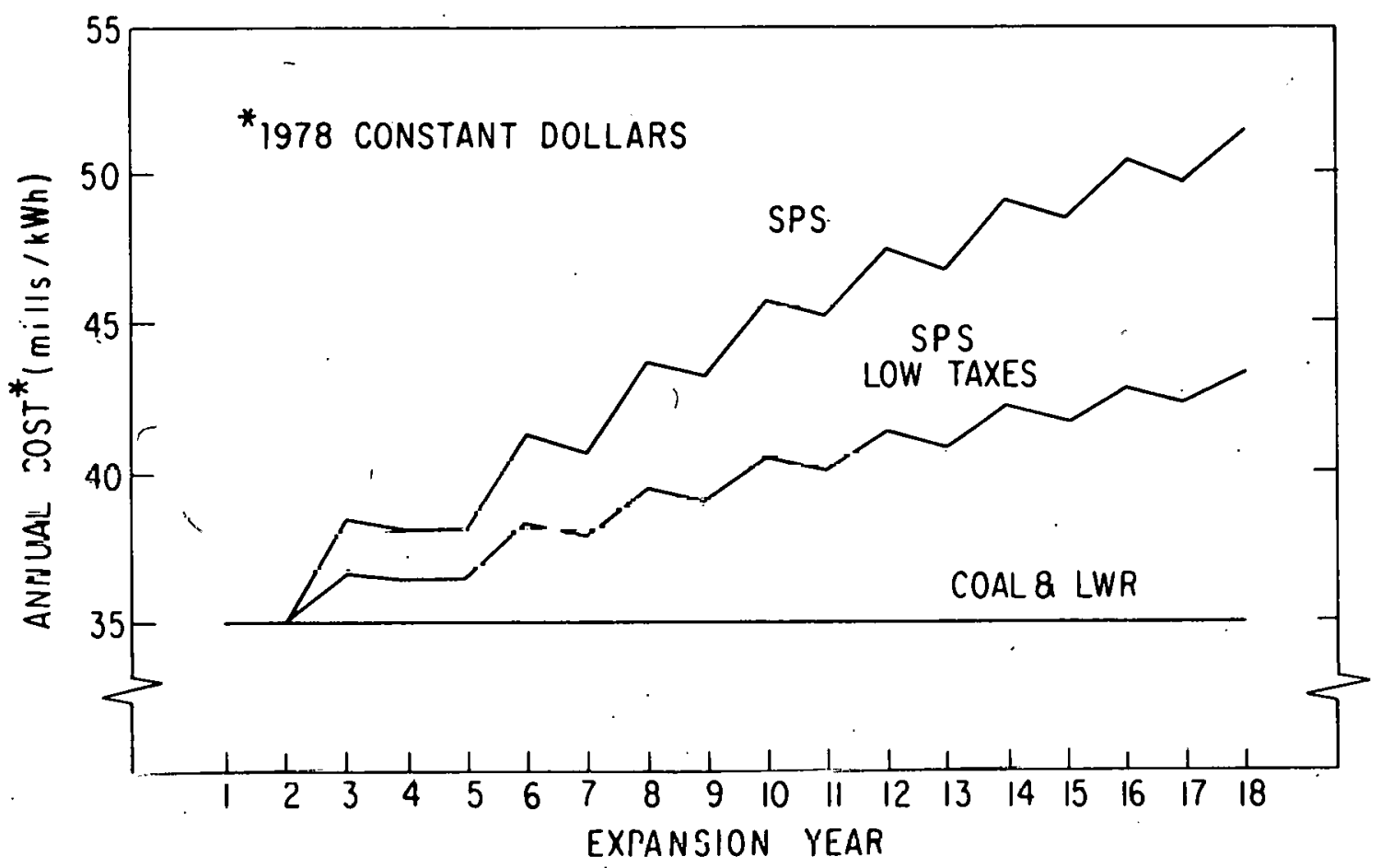

Fig. 4.3. Annual System Generation Costs:

Zero Fuel Price Escalation

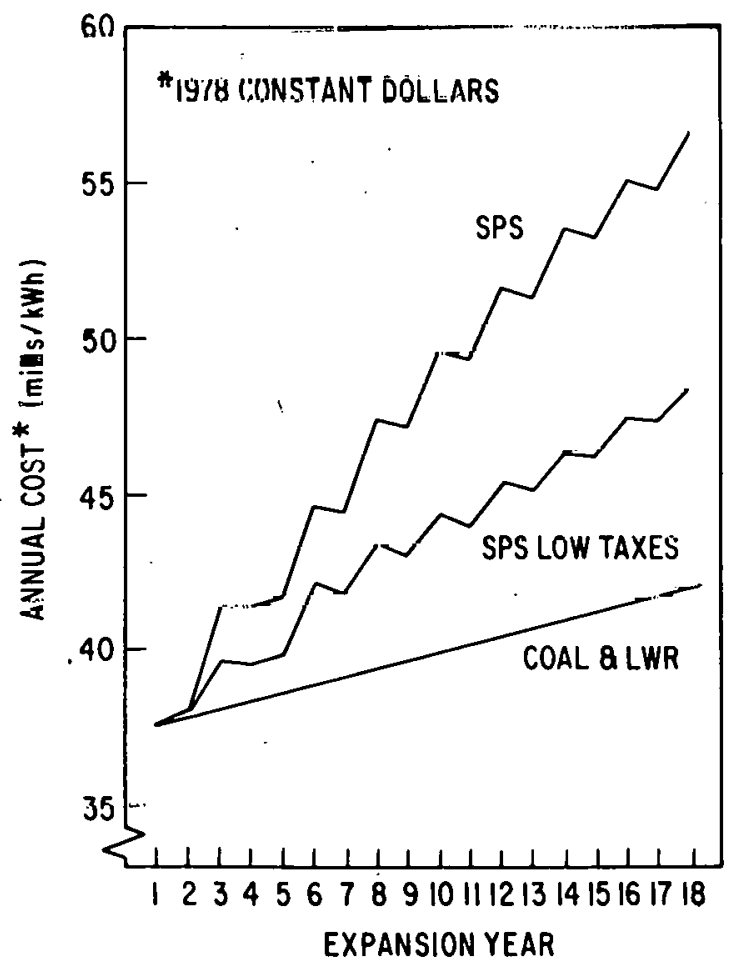

Fig. 4.4. Annual System Generation Costs: Low Fuel Price Escalation 


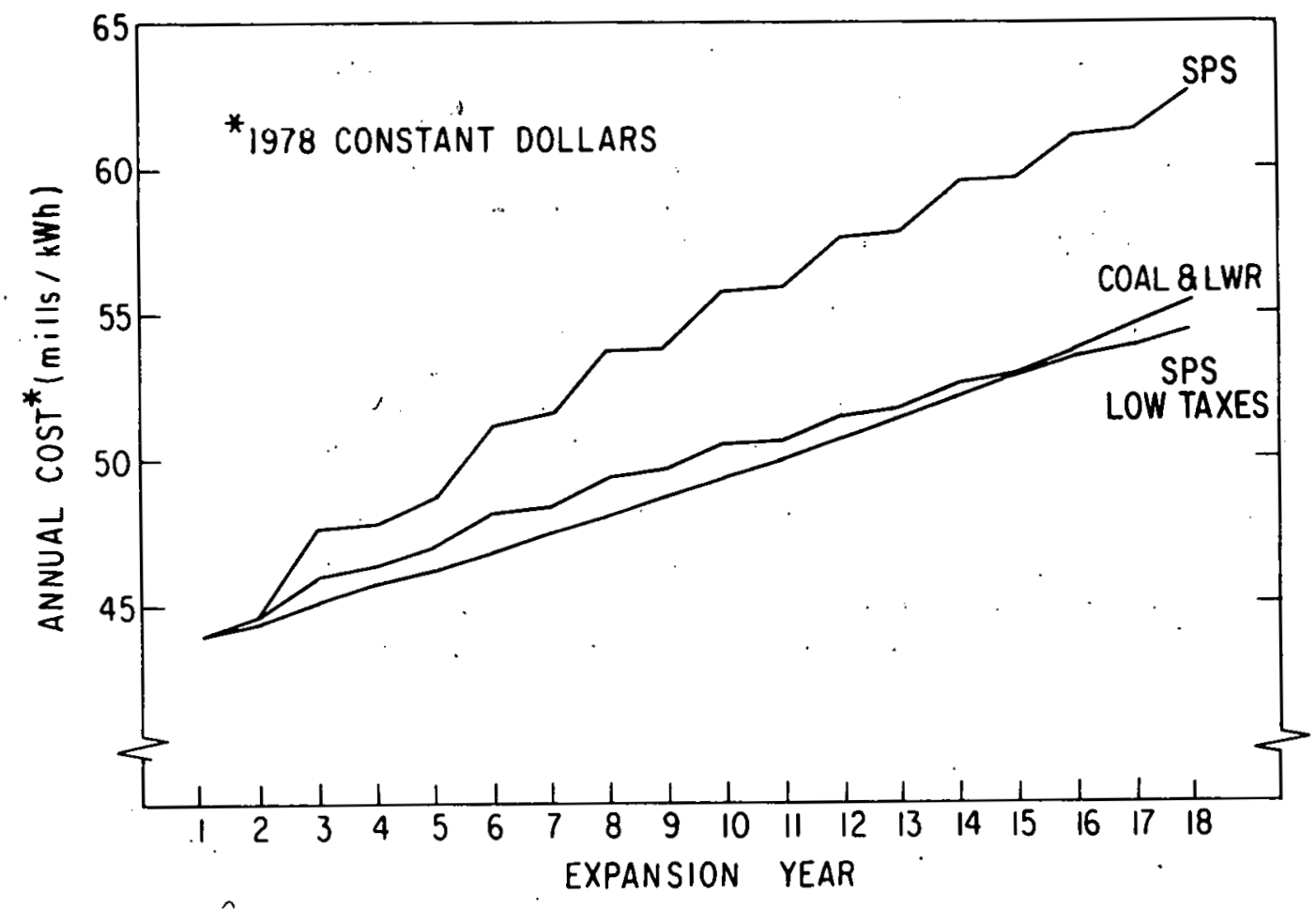

Fig. 4.5. Annual System Generation Costs: Medium Fuel Price Escalation

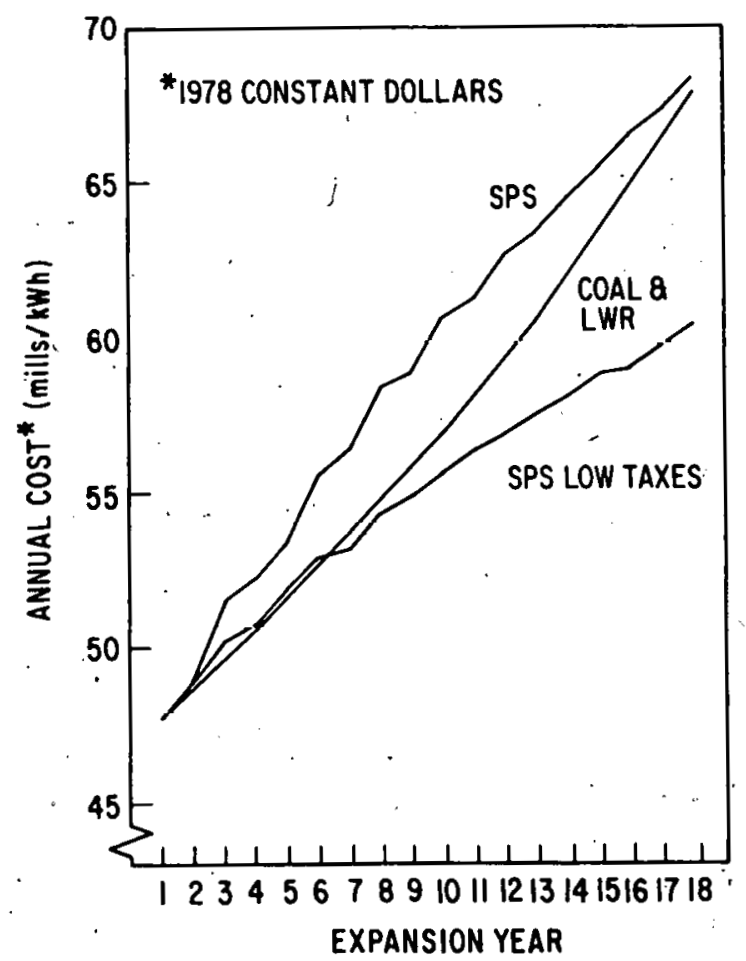

Fig. 4.6. Annual System Generation Costs: High Fuel Price Escalation 
Table 4.7. Annual System Generation Costs, Last Year (18) of Expansion (1978 mills $/ \mathrm{kWh}$ )

\begin{tabular}{|c|c|c|c|c|}
\hline \multirow{2}{*}{$\begin{array}{l}\text { Primary } \\
\text { Expansiona }\end{array}$} & \multicolumn{4}{|c|}{ Fuel Price Escalationb } \\
\hline & Zero & Low & Medium & High \\
\hline Coal-LWK & 34.8 & 42.0 & 55.3 & 67.9 \\
\hline SPS & 51.4 & 56.5 & 62.5 & 68.2 \\
\hline SPS (Low Tax)C & 43.3 & 48.3 & 54.4 & 60.3 \\
\hline
\end{tabular}

a See Table 4.5 for description of expanston schemes.

bsee Table 4.6 for description of fuel price escalarions.

cSame as SPS expansion but with no international or federal income tax applied to SPS satellite.

Table 4.8. Leveliz.ed System Generation Costs (i978 mills $/ \mathrm{kWh}$ )

\begin{tabular}{|c|c|c|c|c|}
\hline \multirow{2}{*}{$\begin{array}{l}\text { Primary } \\
\text { Expansiona }\end{array}$} & \multicolumn{4}{|c|}{ Fuel Price Projectionb } \\
\hline & Zero & Low & Medium & High \\
\hline Coa.1-T.WR & 34.8 & 39.7 & 49.2 & 56.9 \\
\hline SPS & 43.7 & 47.6 & 54.0 & 59.0 \\
\hline SHS (Low-tax)c & 39.4 & 43.3 & 49.7 & 54.7 \\
\hline SPS No $\cos t^{d}$ & 28.5 & 29.4 & 39.7 & 40.8 \\
\hline
\end{tabular}

asee Table 4.5 for description of expansion schemes.

bSee Table 4.6 for description of fuel price escalations.

-Same as SPS expansion but with no international or federal Income tax applied to SPS satellite.

dSPS capital cost and O\&M rnsts set equal to zero.

Some convergence in annual system generation costs with SPS expansion versus coal-LWR expansion is also apparent with the wedlum fuel price projection (see Fig. 4.5). The lower initial fuel costs and $1 \%$ lower fuel price escalation rates, however, significantly affect the rate of convergence as compared with the high fuel price projection. That is, given the rate of convergence displayed in Fig. 4.5 (medium fuel price projection), it is estimated that equal annual system generation costs would be achieved between the SPS fully taxed expansion and the coal-LWR expansion at a point approximately 20 years beyond the last year of this analysis. 
Removing a $2 \%$ international tax (or other payments in lieu of property taxes) and all federal income taxes attributable to the SPS satellite reduces the 18-year levelized system. costs by $4.3 \mathrm{mill} / \mathrm{s} / \mathrm{kWh}$ and reduces the last-year (year 18) annual system generation costs by. $8.1 \mathrm{mills} / \mathrm{kWh}$. (See Tables 4.8 and 4.7, respectively.) Reducing the tax burden on SPS enables it to be competitive with the coal-LWR expansion schemes under high fuel cost conditions. As shown in Figs. 4.5 and 4.6 , the annual system generation costs for a low: taxed SPS expansion equals the fully taxed coal-LWR expansion between the 14th and.15th year and between the sixth and seventh year under the medium and high fuel price projections, respectively. However, only under the high price projection does the levelized generation cost for the low taxed.SPS expansion fall below that of the conventional system expansion scheme. Under the slightly lower medium price projection, levelized system generation costs for the low taxed SPS expansion are still $1 \%$ above the levelized cost for the coal-LWR expansion.

Under the zero and low fuel cost projections, the generation costs for the SPS expansion show no trend toward convergence or possible competitiveness within any reasonable time. Even with the cost advantages of reduced taxes, the SPS expansion costs are substantially greater than those associated with the coal-LWR expansion schemes.

The step-type characteristic of the SPS expansion curves is caused by the large SPS unit size $(5,000$ MWe) as compared to the smoother system expansion curves displayed for installation of the 1,250 MWe coal and LWR units. These and other system integration effects are sensitive to key performance and cost assumptions. Design and operating characteristics of the SPS, such as forced outage rates, have significant impacts on system reliability and thus on system: costs. For this reason, performance estimates must be carefully considered. As the results show, cost comparisons are also strongly influenced by key economic conditions (e.g., SPS capital costs, initial fuel costs, and escalation rates) assumed for each calculation.

This analysis uses only the lower bound of capital costs developed for each of the technologies and the variations due only to fuel costs and their projections. We emphasize that the uncertainty of the capital costs of the sys and the other alternatives is vcry large. The use nf the upper bound of the capital cost estimates or the use of some intermediate value would significantly alter the results presented here.

It is possible to calculate a target capital cost goal. for the SPS technology that would allow it to compete on an economic basis with the other technologies. The objective is to determine the SPS capital cost that, when applied in its own expansion scheme, gives the same levelized system generation cost as the coal-LWR expansion scheme. System effects are accounted for since the expausion schemes werc originally defined as maintaining the same level of overall system reliability.

The break-even costs of the SPS can be investigated by varying its capital cost in repetitive economic calculations until the levelized system costs in the SPS expansion equal those for the expansion scheme using the alternative technologies. However, since levelized system costs in the SPS expansion vary almost linearly with SPS costs, a simple interpolation can be 
made if the levelized system generation costs for the SPS expansion are known at only one other paired value of the SPS capital and O\&M costs. For this analysis, interpolations were made between the levelized system generation costs determined with the-SPS capital cost assumed at $\$ 3400 / \mathrm{kW}$ and O\&M costs at $16 \mathrm{mills} / \mathrm{kWh}$ (SPS expansion, Table 4.8) and with SPS capital and O\&M costs set equal to zero (SPS, No cost, Table 4.8). Since both SPS capital cost goals and $O \& M$ cost goals are interpolated in this manner, a paired datum results from the methodology. Thus, to provide a more meaningful presentation, the data were adjusted by normalizing to three values of initial year SPS O\&M costs. The normalization procedure simply adjusts the interpolated capital and $O \& M$ pair to a specified $O \& M$ cost while maintaining the same total SPS levelized cost implied by the interpolated data.

Table 4.9 displays the target capital costs necessary for the SPS to compete in the system expansion and under the fuel and alternative technology cost assumptions described previously. The cost goals are specified for each of three values of SPS O\&M costs because of the wide range of published SPS O\&M costs. Also shown are the SPS capital coste neccosary for it to cumpele economically under the fully taxed and low tax assumptions.

Competitive capital costs range from $\$ 575 / \mathrm{kW}$ to $\$ 2,845 / \mathrm{kW}$ for the fully taxed SPS with an $0 \& \mathrm{M}$ cost of $16 \mathrm{mills} / \mathrm{kWh}$. At $3 \mathrm{mills} / \mathrm{kWh}$, the fully taxed range increases to $\$ 1,735 / \mathrm{kW}$ to $\$ 4,000 / \mathrm{kW}$. IInder the low SPS tax assumptions, competitive costs are generally increased from $30 \%$ to $140 \%$ above competitive costs for the corresponding fully taxed case. The larger relative increases are exhibited under the higher $O \& M$ and lower fuel cost assumptions.

An examination of Table 4.9 [when compared with recent NASA rnntractor esctmates 2 of the average SPS costs of approximately $\$ 34 n \mathrm{n} / \mathrm{kW}, \$(1978)]$ ohowo that the SPS may be cost competitive under very high fuel price scenarios. This result is consistent with previous observations resulting from the $d i r e c t$ cost comparisnns, which ohowed that tle luwer range of the sps generation

Table 4.9. Economically Competitive SPS Capital Costs $(1978$ \$/kW)

\begin{tabular}{lcrccc}
\hline \multirow{2}{*}{$\begin{array}{c}\text { SPS Tax } \\
\text { As sumption }\end{array}$} & $\begin{array}{c}\text { First Year } \\
\text { O\&M Cost } \\
(\mathrm{mil1s} / \mathrm{kWh})\end{array}$ & Zero & Low & Medium & High \\
\cline { 3 - 6 } F111y Taxed & 16 & 575 & 1,305 & 1,780 & 2,845 \\
& 9 & 1,200 & 1,930 & 2,405 & 3,470 \\
& 3 & 1,735 & 2,465 & 2,940 & 4,000 \\
Low Tax & 16 & 1,365 & 2,150 & 3,160 & 4,165 \\
& 9 & 1,990 & 2,775 & 3,785 & 4,790 \\
& 3 & 2,520 & 3,310 & 4,320 & 5,325 \\
\hline
\end{tabular}


costs fell within the range of costs projected for alternative technologies. The low capital costs that would have. to be achieved by the SPS to be economically competitive under more reasonable fuel cost projections indicates that there is a potential for the SPS costs to.far exceed the cost for alternatives in the 2000-2030 time frame.

Again, this analysis is based on the assumed system characteristics, forced outage rates and costs. Changing these input assumptions would thus alter the results. However within reasonable limits of input data variations, the overall conclusions would remain unchanged.

\subsubsection{Cost and Performance Uncertainty}

Throughout the preceding section, SPS costs have been compared with those of alternative electric generation technologies through an examination of possible capital and fuel cost ranges. Both the direct cost comparison and the systems analysis have shown that within the range of assumptions made here, some overlap in generation costs is possible under very high fuel cost projections. The ranges assigned to the capital and fuel costs were a preliminary attempt to quantify the uncertainty surrounding cost comparisons of technologies 20 to 50 years in the future.

In this section, the question of uncertainty in future technology cost and performance achievements is discussed at a somewhat more detailed and theoretical level. It is shown that, in general, large projects (both space and terrestrial) tend to overrun original cost estimates. Also discussed are some of the underlying reasons for these cost overruns, as well as a preliminary methodology for better assessment of cost differences under uncertain future conditions.

Comparison of the SPS to alternative energy systems is difficult because of the following considerations:

- Technologies and system concepts are still evolving.

- There are technical barriers to be overcome.

- Large R\&D programs are required before commercialization of many of the alternatives will be possible.

- Energy and economic payback will begin far in the future.

In addition, there are many external factors that introduce great uncertainty, e.g., the demand for electricity in the post-2000 period and the cost and availability of competing technologies. Despite the uncertainty, decisions need to be made regarding SPS. Previous sections have treated uncertainty by establishing ranges of future costs. In what follows, the uncertainty issue is discussed using the language of probability distributions. It should be understood that in most instances, information to establish such distributions is lacking.

Experience shows that the uncertainty of forecasting the cost and duration of large-scale projects 1s great, particularly when there arc 
questions of technical feasibility to resolve. For example, capital costs of certain nuclear plants put on stream between 1972 and 1977 were from $100 \%$ to $165 \%$, respectively, above estimates made in 1967.37 Examples for space activities show that NASA space projects overran their initial estimates an average of $70 \%$, with large projects usually having the larger overruns (Fig. 4.7).38,39 One notable exception was the Apollo program, which was undertaken at approximately its original estimate of $\$ 20$ billion.40-45 Figure 4.7 shows the distribution of cost overruns by cumulative expenditure for 22 NASA projects totaling $\$ 19$ billion and for these projects plus the $\$ 20$ billion Apollo program. Unfortunately, similar data are not yet available on the Space Shuttle Program. A recent study46 by Ránd Corporation for the Department of Energy shows similar results for ten pioneering energy process plants (Fig. 4.8) and also for various weapons development programs, public works, and major construction projects (Table 4.10). The experiences with energy, space, and other projects give a hint of the lower limit of uncertainty to be expected from the SPS, whnse time span from current estimales lu cumplerion is two to three times as long as for the projects just cited.

Such projects almost always involve initial underestimates of cost because, among other things, all of the events and items that should be included cannot be foreseen. There are many variables, parameters, and intangibles that contribute to the uncertainty.

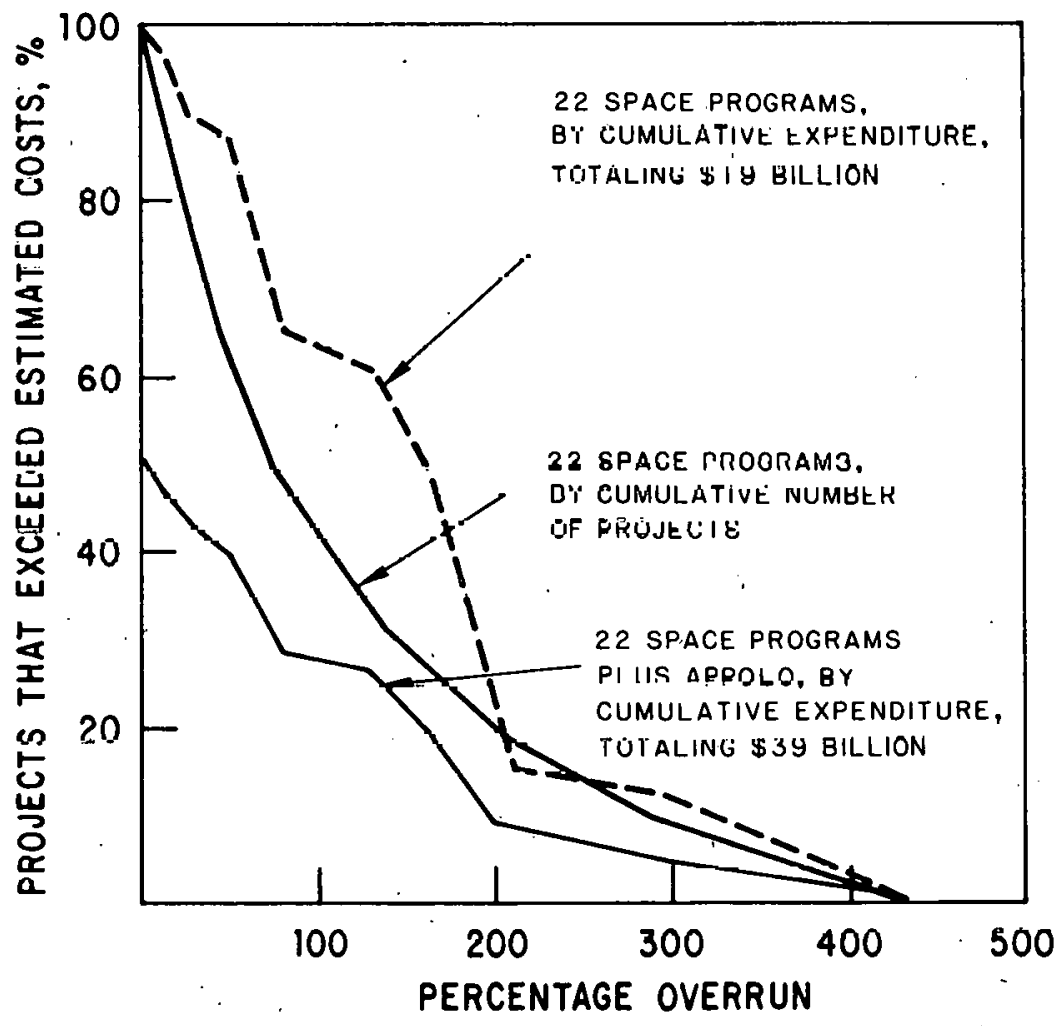

F1g. 4.7. Comparison of Real and Estimated Costs of 22 NASA Space Projects and Apollo (Sources: Refs. 38, 40) 


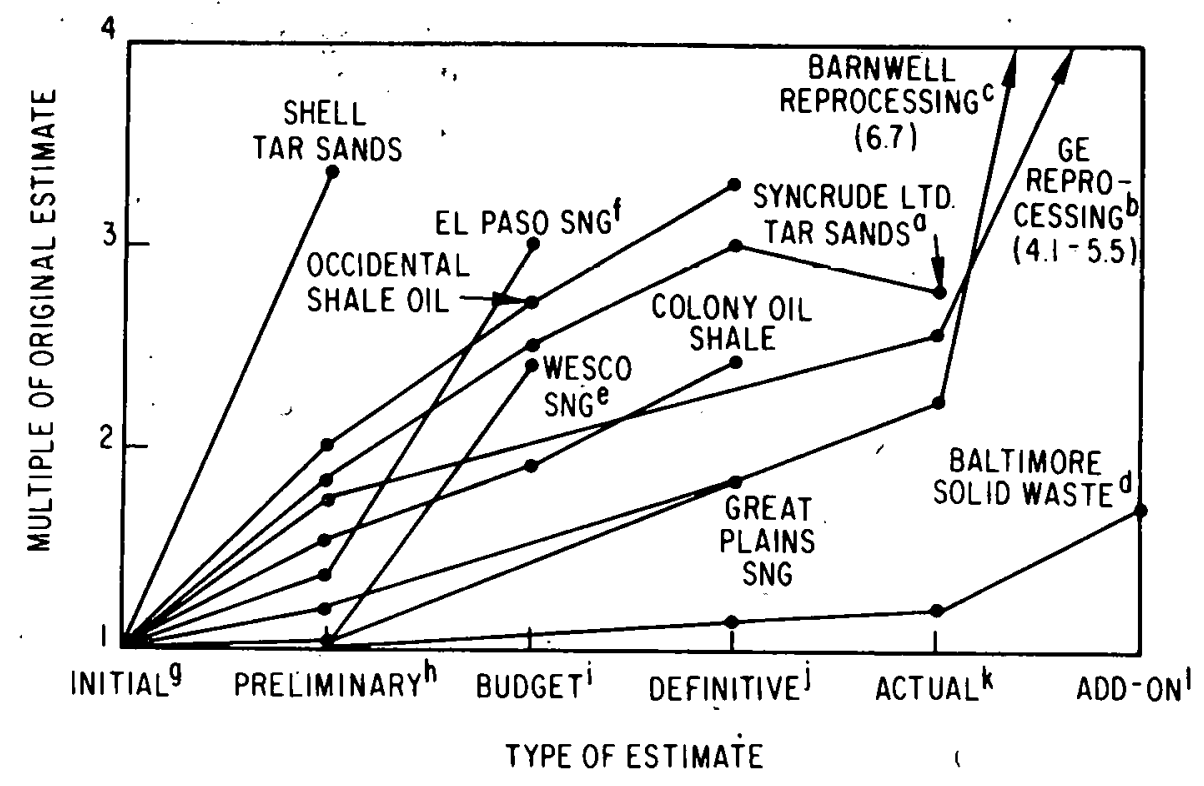

Fig. 4.8. Cost Growth in Pioneer Energy Process Plants (Constant Dollars) [Source: Ref. 41]

aplant start-up began September 1978 .

bPlant failed to operate.

cPlant start-up indefinitely delayed because of regulatory problems.

dinitial estimate not available. Plant has failed to achieve sustained operation.

Preliminary estimates. Initial estimate not available.

fhird estimate is still a preliminary estimate.

gInitial estimates are based on engineering concepts rather than a commercial

design. They rarely if ever are based upon conditions at a particular site and are sometimes based upon a scope significantly different from that of the plant actually designed and constructed. In most cases the scope in the initial estimate was the same as that for the commercial design.

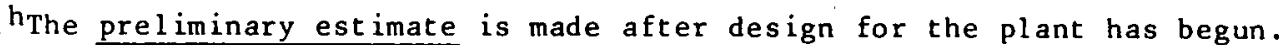
Plant scope and basic layout including major equipment are set, and design is generally five to ten percent complete. The preliminary estimate is also known as a "phase I authorization" or "factored" estimate.

iThe budget (or control) estimate, also known as the "phase I I authorization," is generally made when design is at least 30 percent and usually 50 percent complete. When the budget estimate is made late in design ( 50 percent to 70 percent complete), it may be the last formal estimate for a project. It will then be refined as engineering is completed and construction begins.

jThe definitive estimate is made when project design and engineering are 90 to 100 percent complete. Site preparation and possibly even construction may have begun on the plant when the definitive estimate is complete.

kActual costs are reported capital costs when the plant, is started up.

${ }^{1}$ In a few cases we have added a sixth category - "Add-on." The se are estimated additional capital costs necessary for the plant to operate as expected or necessary to meet regulatory requirements. 
Table 4.10. Summary of Cost Estimating Experience for Various Large Projects

\begin{tabular}{lccc}
\hline \multicolumn{1}{c}{ Items Estimated } & $\begin{array}{c}\text { Mean of Actual to } \\
\text { Estimated Cost }\end{array}$ & $\mathrm{N}^{\mathrm{a}}$ & $\begin{array}{c}\text { Standard } \\
\text { Deviation }\end{array}$ \\
\hline Weapons, 1950s & 1.89 & 55 & 1.36 \\
Weapons, 1960s & 1.40 & 25 & 0.39 \\
$\begin{array}{l}\text { Public works } \\
\text { Highway }\end{array}$ & 1.26 & 49 & 0.63 \\
$\quad$ Water projects & 1.39 & 49 & 0.70 \\
Building & 1.63 & 59 & 0.83 \\
Ad hoc & 2.14 & 15 & 1.36 \\
Major construction & 2.18 & 12 & 1.59 \\
Energy process plants & 2.53 & 10 & 0.51 \\
\hline
\end{tabular}

Source: Ref. 41, p. 87

${ }^{a}$ Number of projects in sample.

\section{Capital Cost of SPS}

The uncertainty of the capital cost estimates for the SPS is large. Estimates of some of the components of capital cost that have appeared in the past year vary by factors of two to five.26,29,30. One large capital cost driver is the cost of solar cells and even the published value for the 1990 silicon cell cost target has varied by a factor of three (Fig: 4.9).

Based partly on these data, and on the ranges developed in Sec. 4.1.2, along with various engineering judgments, possible ranges of the major components of SPS costs have been estimated. These ranges and most probable values (taken to be the Rockwell SPS estimate) 6 are given in Table 4.11. All are based on generally expected conditions; R\&D costs are not included.

(The component cost ranges presented in Table 4.11 were derived to be consistent with the Rockwell cost estimate ${ }^{6}$ and with the range of possible capital costs for SPS as previously presented in Sec. 4.1.2. These were derived primarily to exemplify the problems and difficulties in using probability mathematics, in aggregating partially correlated uncertainty distribu$t$ ions of individual components. In that regard, the following discussion on cost uncertainty should be viewed not so much as a definitive statement or conclusion about SPS cost uncertainties, but rather as a statement of the difficulties in treating this problem in a theoretically correct manner.

In any event, an estimate of the uncertainty in the total capital cost of SPS can be obtained from the ranges of component parts. This requires describing the ranges by probability distributions and combining them with probability mathematics. The various cost ranges in Table 4.11 could be converted into the probability density distributions. These can be combined 


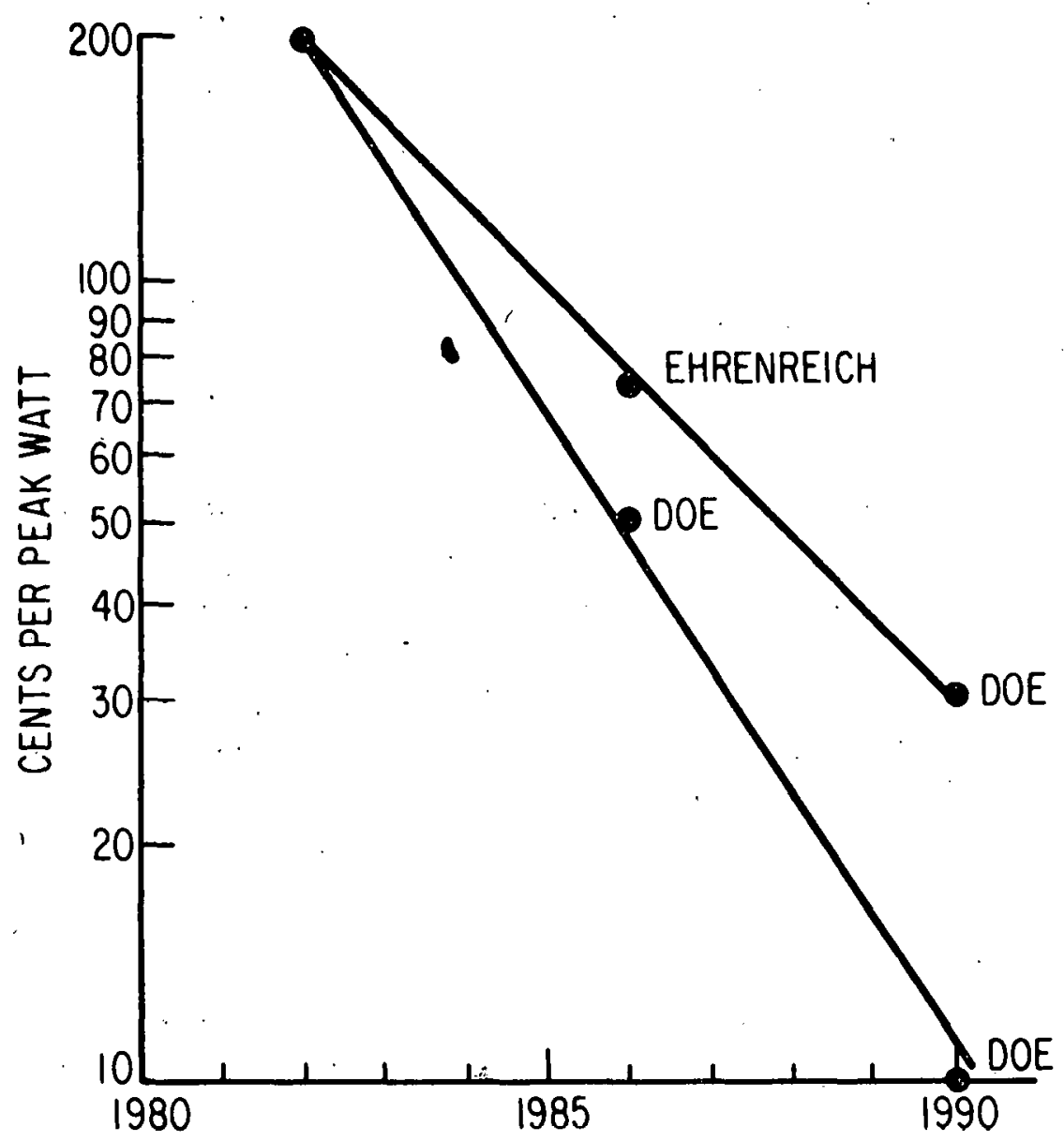

Fig. 4.9. Projections of Solar Cell Cost, Cents/Peak Watt (Source: Ref. 42)

(e.g., by Monte Carlo techniques) to get a distribution of their sum, but a fundamental difficulty arises: the distributions are certainly correlated to some extent. For example, if material costs were generally high, all the components of cost at this aggregated level would be pushed to the high side, and so would labor costs. A tendency to underestimate costs may apply to all components as will the fact that the costs are interrelated by design or system equations. Figure 4.10 illustrates this problem; it shows the probability distribution of capital cost obtained by treating individual components of cost as completely independent and the distribution obtained by treating the component costs as completely correlated. The means are the same but the shapes of the two curves are much different; the existence of positive correlation spreads. the distribution over a wider range. The correct distribution is presumably somewhere between the two.

Unfortunately, because the cost data are presently available mainly in aggregated form, it is not possible to go further in the uncertainty analys is at this time. The correct procedure would be to derive the total capital cost from a single data base of costs and ranges for labor, materials, and capital costs at a sufficiently disaggregated level. The question is not one of precision but rather of preserving essential interrelationships. 
Table 4.11. Estimated Range of Rockwell Costs ( $\$ / \mathrm{kW})$

\begin{tabular}{lrrrr}
\hline \multicolumn{1}{c}{ Cost Component } & \multicolumn{1}{c}{$\mathrm{C}_{\mathrm{L}} \mathrm{A}^{\mathrm{C}}$} & \multicolumn{1}{c}{$\mathrm{C}_{\mathrm{M}}^{\mathrm{b}}$} & \multicolumn{1}{c}{$\mathrm{C}_{\mathrm{H}}{ }^{\mathrm{a}}$} & \multicolumn{1}{c}{$\mathrm{C}^{\mathrm{c}}$} \\
\hline Energy Conversion & 210 & 370 & 1,233 & 604 \\
Power Transmission & 378 & 630 & 1,638 & 882 \\
Space Construction \& Support & 115 & 230 & 575 & 307 \\
Space Transportation & 215 & 380 & 1,267 & 621 \\
Ground Receiving Station & 480 & 720 & 1,680 & 960 \\
Management and Integration \& Other & 120 & 180 & 600 & 300 \\
Tutal & 1,518 & 2,510 & 6, yy3 & 3,674 \\
\hline
\end{tabular}

${ }^{a} C_{L}$ and $C_{H}$ are the low and high values of the cost range.

${ }^{b} C_{M}$, the Rockwell estimate, is taken as most probable value. Derived from Ref. 6, p. 459 in the following manner:

- From original estimate of $\$ 2,880 / \mathrm{kW}$ the $13 \%(\$ 370 / \mathrm{kW})$ mass contingency factor was subtracted leaving a total. of $\$ 2,510 / \mathrm{kW}$.

- Remaining costs were then broken down as follows in $\$ / \mathrm{kW}$ :

Rockwell Estimate $(\$ / \mathrm{kW})$

Satellite $\quad 1,065$

\begin{tabular}{lr}
\multicolumn{2}{c}{ Table Value $(\mathrm{S} / \mathrm{kW})$} \\
\hline Energy Conversion (Cells) \\
Power Transmission & 370 \\
Other & 630 \\
& $\frac{65}{1,065}$
\end{tabular}

Space Construction and Support 230

Space Transportation 380

Space Construction and Support. 230

Ground Receiving Sta. 720

Space Transportation $\quad .380$

Mgmt. \& Integration 115

Total 2,510

Ground Receiving Sta.

720

Mgmt. \& Integration

115

Total

2,510

${ }^{c_{C}}$ is the mean value of the resulting triangular distribution assumed as an example and for convenience.

Problems in the Comparison of Technologies

In the first approximation, economic factors affect SPS decisions through a comparison of energy alternatives rather than through the absolute value of SPS energy costs. This makes it possible to reduce some (of the major uncertainties by correctly taking into account the fact that some variables or parameters have the same qualitative effect on the energy sources being compared. For example, an uncertainty in the general level of labor costs will affect a comparison only to the extent that the two alternatives have different requirements for labor per kilowat-hour. 


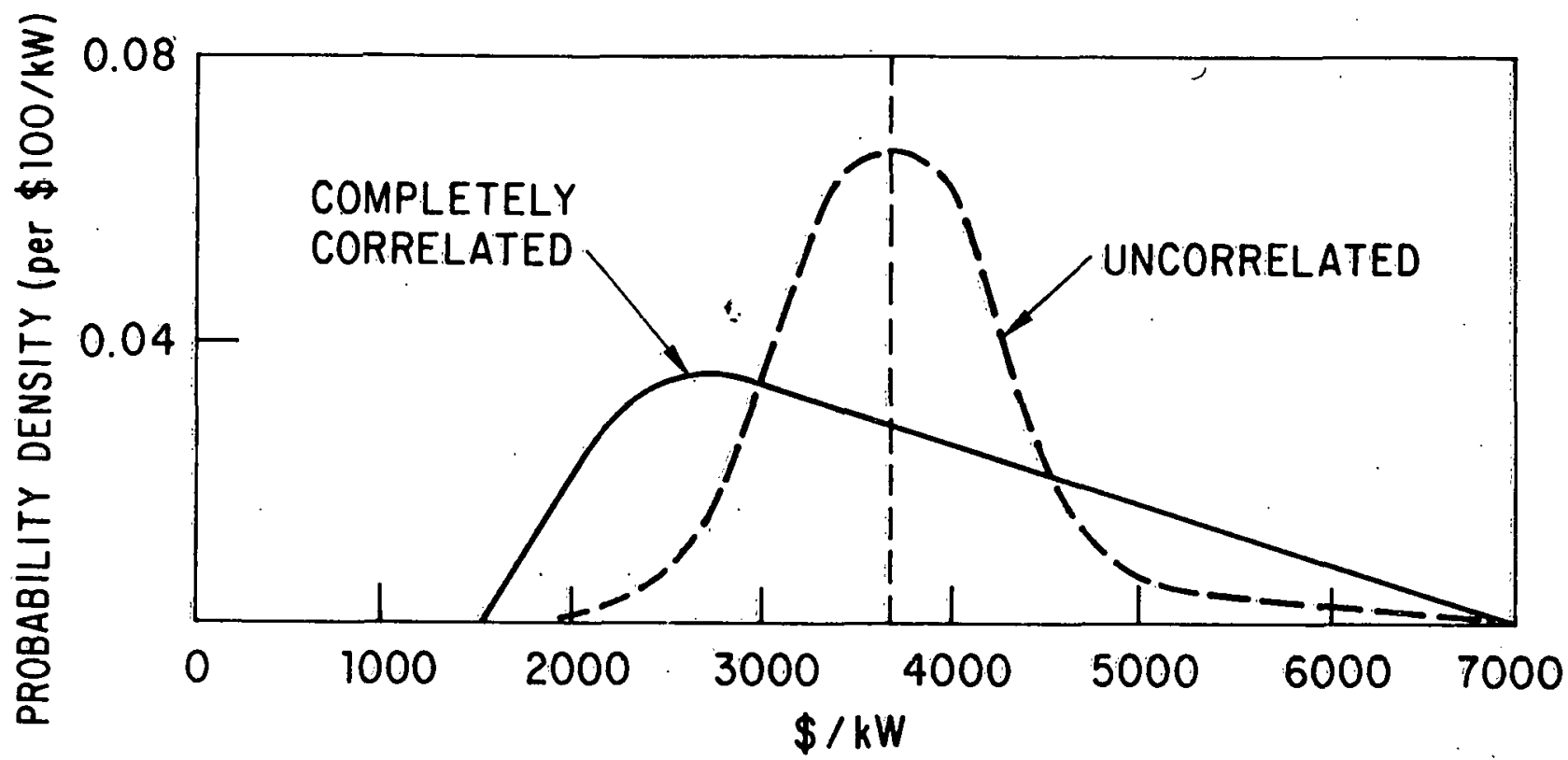

Fig. 4.10. Distributions of the Sum of Cost Elements

The comparison of alternatives makes it necessary to dea1 with lifecycle costs of electricity (or, what is equivalent, levelized costs). The levelized cost is a weighted average such that the present value of the electricity generated over the lifetime of the system, if sold at this average value, would equal the actual present value of all the electricity sold. Such levelized values are strongly dependent on the energy cost and technology implementation scenario used.

The question of the correlation of inputs is now present in a different form. Assuming that the probability distributions of the levelized costs for SPS and coal are separately and properly calculated, there is still the problem of accounting for correlation between the two. A degree of correlation surely exists, since, for example, the price of coal will affect the price of electricity needed to manufacture SPS components.

To take correlation into account in cost comparisons, the distribution of the difference of levelized costs of SPS and coal electricity must be calculated. Clearly, the use of independently derived costs and distributions would miss this effect. To include it in the calculation, a common data base as well as a common energy supply/demand scenario are required.

In order to deal with the difficulties just discussed, certain minimum requirements must be met:

- First, a common data base is required in order to treat such technology pairs, the.elements of which are ranges or probability distributions of disaggregated cost elements. 
- Second, the comparisons should be made over a range of scenarios sufficient to span the reasonable possible outcomes.

- Third, the comparative standing of SPS among energy alternatives should be tracked continually as inputs change with time and $R \& D$.

This section has shown that, in general, large projects tend to overrun their original cost estimates, and, adequate treatment of this problem in an analysis of potential events 20 to 50 years in the future is, at best, a difficult task. The question of correlation between high fuel costs and high materials or construction costs has been raised, and it has been noted that these problems require further assessment. Subsequent analysis for the Final SPS Comparative Assessment will attempt to better address these difficulties in order to provide a more descriptive account of the experted ernnnmir position of the SPS relative to othcr alternatives available in the 2000-2030 time frame.

\subsubsection{Comparison of Terrestrial and Space Photovoltaic Technologies}

Throughout the course of this Preliminary Comparative Assessment, numerous questions have been asked with regard to the adequacy and appropriateness of the direct energy cost (or side-by-side) comparison between SPS and the terrestrial photovoltaic central station (TPV) technologies. A natural question for photovoltaic application is -- What are the costs and performance levels of photovoltaic terrestrial applications in comparison to space applications? In the previous sections, the SPS was rompared with TPV on an individual technology basis but not on a basis whereby electrical generation system effects were accounted for. The system comparison was not made because the system analysis problem for TPV is complex. The leading work on the TPV system analysis was conducted by the General Electric Company for the Electric Power Research Institute, EPRI. 9 Before examining the results of that work, we will briefly discuss the context of this overview of photovoltaic applications.

The current cost and performance analysis effort is classed as preliminary, but this overview of photovoltaic application should be taken as a scouting effort. The objective is to discuss and establish a scope for this comparison and to provide an information base that will help direct any future analysis of more depth. With this perspective some calculations are made based, in part, on the analysis carried out by GE for EPRI.9 In that analysis, established utility generation planning methods were used to study TPV generation with minor modification. The proper criteria for comparison are total utility system costs. The following are the principal conclusions of that study:

- TPV plants have capacity value. On a long-term basis they can contribute to serving the peak loads. This capacity credit, however, was determined by probability calculations. Practical acceptance will probably require further investigation and operating experience. 
- Both the capacity and energy value of TPV plants depend strongly on the characteristics of the utility systems to which they are applied. The cost and types of conventional generation and the relative times of daily load and insolation peaks are particularly important.

- As TPV plant penetration increases, incremental value decreases. The energy displacement shifts to conventional units of lower energy cost, and the capacity displacement diminishes.

- Energy storage dedicated to the TPV plant offers little, if any, advantage. Energy storage has its greatest value as system storage, designed and operated for the benefit of the total utility system.

- The disadvantages of small, dispersed, individual-1oad photovoltaic plants, whether utility- or user-owned, may outweigh the potential advantages. A consideration of many economic, operating, safety, and institutional questions leads to this conclusion. However, in the GE/EPRI study the technical and economic aspects of such plants were analyzed only in the framework of utility ownership and control.

- Of the currently available technologies, simple tilted

- flat plates appear to have the best prospect for economic viability. Very high efficiency technologies, though at present quite speculative, should be pursued because of high potential for reduction of area-related costs.

One important factor in the comparison is the insolation characteristic in each photovoltaic application. The peak flux in space is $1.35 \mathrm{~kW} / \mathrm{m}^{2}$. The annual peak for the U.S. on a surface perpendicular to the sun's rays is approximately $1 \mathrm{~kW} / \mathrm{m}^{2}$. . Except for short periods during eclipses, the annual insolation in space is continuous. On earth there are diurnal, atmospheric, and latitudinal effects. In the U.S., a terrestrial power plant might produce 1,300 to 2,700 full power hours depending on location and whether or not the recelver tracked the sun; compared with this output range is the almost constant production by a plant. in space of about 8,000 full power hours. (Note: full power hours are approximate; high forced outage rates or long maintenance periods would change the values.)

With this general infornation on solar insolation, it is informative to compare the estimates of cell areas that would be required by the two options to provide equal peak electrical power or equal annual energy outputs to the utility grid. With the assumptions that solar cell electrical efficiencies are equal in space and on earth, and accounting for plant losses from cell output to utility grid as given in the SPS system definition and the GE studies, the relative areas needed are as follows:

\section{Relative Cell Areas}

Equal Peak Power

Equal Annual Energy

\section{In Space}

1 (reference)

1 (reference)
On Earth

0.7

$2-4$ 
The simple comparison shows that about $50 \%$ more cell area is needed in space to generate the same peak power as on earth. For equivalent annual energy fed into the utility network, terrestrial application requires 100 to $300 \%$ more cell area.

Before discussing relative costs, a few comments about evaluation of technologies or concepts for the electrical utility system are appropriate. First, in order to evaluate concepts in systems it is not necessary to have equal power or equal energy produced by the concept. Various generating plant options can be used in the system to find the most cost-effective configuration of,plants. Also, by analyzing utility system costs, the value of the concept to the grid can be calculated under assumed conditions, and this value can be compared to the estimated costs. Value is dependent on such factors as forced outage rate, maintenance requirements, aggregate power demand by customers, type and amount of electrical capacity of the system, and, for intermittent technologies, the fraction of rated power generated at the time of high power demand.

Electrical system value calculations for both the SPS and TPV showed that the estimated value of electrical generation by them was significantly below their projected cost of generation. These value calculations result from system and concept reliability, considerations.

For the SPS, the value definitely decreases if its reliability is not high. In addition, the SPS raises reliability questions because the satellite is not located within the U.S. Perhaps it would be tolerable to draw $10 \%$ of the total U.S. generating capacity ( $15 \%$ of electrical energy) from SPS if too much of the capacity is not centered in one utility. This estimate of about $10 \%$ capacity is based on utility reserve margins and the estimated ability of the nation to reduce demand in time of crisis.

For TPV, the GE study showed that the cheapest approach is not to build dedicated storage capacity, because this decreases the value-to-cost ratio. Rather, TPV would be initially added to the system as an energy supplier that generates only during insolation periods with no associated storage. The value of TPV to the system decreases as more photovoltaic generating units are added: the amount of TPV addition that is effective for the system depends on system characteristics; in particular the temporal relationship between peak power demand and solar flux. The order of magnitude of effective addition is usually not large, being just a small percentage of the total system capacity. Thus TPV will probably be added in this way to the system until capital costs become small enough that TPV can be combined with storage for daily cycles. Because insolation may he low on successive days on a regional basis, long-period storage is required for still higher TPV penetration into utility systems. Seasonal variation in insolation, which is more pronounced in northern latitudes, will also limit TPV penetration.

A simple comparison has been made of the SPS energy costs and TPV costs for a number of cases. These are:

A. SPS - 5,000 MW (capital costs are based on Boeing and Rockwe 11 concepts) 5,6 
B. TPV - $200 \mathrm{MW}$, solar cell cost and efficiency comparable to those of the Boeing concept. 5

C. TPV - $200 \mathrm{MW}$, with most costs and the efficiency as defined in the EPRI report. 9

D. TPV - same as case B but with storage sufficient for a capacity factor of $\sim 0.45$.

The general characteristics and assumptions are given in Table 4.12. The final energy costs lack some system impacts. For example, for cases $B$ and $C$ one must add capacity in order to have comparable reliability with case $D$. This capacity addition will increase the costs. Another example is that system fuel credits per $\mathrm{kW}$ of installed capacity are higher for the SPS than for TPV. To delineate the effects, the system impacts of representative U.S. utility networks must be studied. In general, the costs (neglecting system effects) should be compared with $4 \notin / \mathrm{kWh}$ for other technologies.

The capital cost numbers are based on the low end of the cost distributions. Whereas the TPV costs are largely dependent on the solar cell cost and performance, the SPS is dependent not only on these factors but also on

Table 4.12. Cost Comparison (1978 Dollars) for the Photovoltaic Overview, by Plant Type, Output, and Cell Type

\begin{tabular}{|c|c|c|c|c|c|}
\hline \multirow[b]{2}{*}{ Cost Factor } & \multicolumn{2}{|c|}{ SPS, $5000 \mathrm{MW}$} & \multicolumn{2}{|c|}{ TPV, $200 \mathrm{MW}$} & \multirow{2}{*}{$\begin{array}{c}\text { TPV plus } \\
\text { Storage, } \\
200 \mathrm{MW}, \\
\mathrm{Si}\end{array}$} \\
\hline & GaAlAs & si & Si & Undefined & \\
\hline Nominal Cell Efficiency, $\%$ & \multicolumn{2}{|c|}{ a } & 16 & 12 & 16 \\
\hline Concentration Ratio & $1: 8$ & 1 & 1 & 1 & 1 \\
\hline Cell Area, $\mathrm{km}^{2}$ & 27 & 50 & 1.3 & 1.7 & 2.6 \\
\hline Cel1\& Support Cost, $b \% / \mathrm{m}^{2}$ & 75 & 46 & 78 & 84 & 78 \\
\hline Plant Capital Cost, $\$ / k W$ & \multicolumn{2}{|c|}{3,400} & 1,200 & 1,500 & 2,700 \\
\hline $0 \& M$ Cost, $\$ 10^{6} / \mathrm{yr}$ & \multicolumn{2}{|c|}{620} & 3 & 3 & 6 \\
\hline Capacity Factor & \multicolumn{2}{|c|}{0.90} & 0.25 & 0.25 & 0.45 \\
\hline Energy Cost, $\notin / \mathrm{kWh}$ & \multicolumn{2}{|r|}{6} & 6 & 8 & 7.5 \\
\hline
\end{tabular}

aThe base efficiencies for SPS GaAlAs and $\mathrm{Si}$ cells are $20 \%$ and $17.3 \%$, respectively. Because of the way changes in efficiencies are accounted for in TPV, the $16 \%$ is equivalent to $17.3 \%$.

${ }^{b}$ The cell and cell support costs for the SPS and TPV are not comparable because the construction of the support and panels are different. For SPS, some space construction costs are not included. No allowance has been made for space-rated versus terrestrial-rated photovoltaic cells; present sps design consideraliuns do nut make such a differentiation. 
other items such as the rectenna and transmission portions of the plant. Thus, if cell costs are low, this has a larger favorable impact on TPV than on the SPS; if high costs occur, the SPS is favored.

The estimated generation costs for the SPS and TPV are in the same range, and each has the potential to make a significant contribution to electricity production that may justify R\&D expenditures; however, they have different roles in the utility system. Initially they would not compete as energy producers; both could be selected to serve the same power pool, that is, at small penetration there would be little effect on the utility system of adding incremental SPS or TPV technologies. However, large penetrations would be a different matter.

\subsubsection{Development Costs}

Boeing éstimated front-end costs on the basis of the reference system scenario, which predicates a 20-year development schedule and a 30-year deployment schedule (60 5-GW satellites).6a These costs amount to $\$ 100-110$ billion and are broken down as follows (Fig. 2, p. xviii):

- Research costs: mainly ground-based research to address environmental and social issues and alternative systems, resulting in a preferred system;

- Engineering: development and testing of prototype subsystems, resulting in specifications for demonstration units and production facilities;

- Demonstration: tlight tests of a lUU-2UU MW unit integrated with a commercial network;

- Investment: development of industrial infrastructure, e.g., transportation, photovoltaic, and klystron manufacturing facilities.

- Construction and implementation: the first 5-GW SPS unit put into place.

It is important to note that these cost estimates assume that all effort is specific to the SPS. The benefits from generic research or from cost sharing (e.g., industry or other tederal program support tor photovoltaics manufacturing facilities) have not been considered. Such cost modifications could amount to $50-70 \%$ of the $\$ 102.5$ billion. $6 \mathrm{c}$

Since comparable cost data for the other six technologies were not available, side-by-side. comparisons of the costs or the benefits or disadvantages of public expenditures were not attempted.

\subsubsection{Observations}

The preliminary cost comparison has resulted in the development of additional insights into the difficulties of cost and performance evaluation of SPS and alternatives. As in most such evaluations, there is a lack of 
good, consistent cost and performance data; however, the importance of assessing uncertainty in cost and performance is highlighted because of the long time to commercialization and the many factors that affect the energy future. Cost and performance estimates for technologies must be made from a common base and integrated with state-of-the-world conditions. The following analyses would be of benefit to the Concept Development and Evaluation Program. Some observations gained from performing this preliminary cost comparison are also made. Environmental factors that weigh heavily on comparisons are not explicitly dealt with in this section.

Individual Technology Comparison

The analysis for the 2000-era conditions shows, in general, that the estimated life-cycle energy costs are high for SPS compared with many alternatives but that the costs may overlap because of the large uncertainty range. Although there is some apparent overlap in estimated energy costs, this overlap may not be real because factors that contribute to high cost in one technology may also contribute to high costs for SPS technology.

\section{Technology Comparisons in a Utility System Context}

Reliability goals for SPS in terms of target forced outage rates are important. A 5,000 MW size in the post-2000 era will not exact undue system reliability penalties if the forced outage rate is low ( 0.05$)$, even with high SPS penetrations. Some electrical system stability analyses should be considered to help establish conditions, size, and performance goals for sPS.

\section{Application of Photovoltaic Generation}

Both SPS and TPV appear as high cost energy producers. Their estimated values* to the electrical system are significantly below their costs.

SPS: Two ground rules for the SPS project are that the SPS will become commercial in the year 2000, and that $300 \mathrm{GW}$ of SPS capacity will be installed in the subsequent 30-year period. This may be an unrealistic deployment schedule because such factors as demonstration of the technology, utility planning, and development of the supply infrastructure were not collectively considered. The development of scenarios addressing these and other economic considerations is necessary. The need for a nationally reliable electrical energy supply could limit SPS generation; however, a limit of $10 \% \mathrm{U} . \mathrm{S}$. capacity ( $215 \%$ of electrical energy) for the SPS would mean that $3,000 \mathrm{GW}$ of national capacity in 2030 would accommodate the assumed $300 \mathrm{GW}$ for the SPS.

TPV: Terrestrial photovoltaics will initially be placed in utility systems as small additions without dedicated electrical storage because storage decreases the value to cost ratio of TPV. This technology is currently receiving more $R \& D$ attention than the SPS. TPV characteristics and development needs will permit easier and faster commercial application of TPV than of the SPS. Cell costs and efficiency are the major unknowns. Initially, the SPS and TPV are not competitors in utility systems. The

*See Sections 4.1.4 and 4.1.6 for complete discussion. 
penetration of TPV into a utility system will initially be limited to a small fraction of the utility generating capacity.

Fusion

Although fusion technology has been characterized in the comparatime assessment, the published cost information does not provide an adequate basis for cost comparison. The main reason for this is the lack of technical definition of the fusion power plant. The fusion concepts have yet to reach the energy break-even point in laboratory apparatus, and even when this is done, formidable enginnering problems remain.

\section{Uncertainty}

It is important to obtain some estimate of the cost uncertainty associated with the cost comparison. By necessity, the uncertainties used in the preliminary analysis were in large part judgmental. Given more time and resources, more refined methods could be applied. There would always, however, be some judgment required in selection of basic data. The problem can be divided into two parts: (1) the technology and its closely associated performance-based costs and (2) costs at large as represented by state-ofthe-world conditions. The possible correlation of cost factors in the comparison can be assessed by using scenarios that specify material costs, average labor costs, and world conditions.

\section{Scenarioo}

To date, the economic variable has been defined in terms of reasonable ranges and used in the energy cost analysis. Future efforts need to define scenarios that specify the economic variables required for cost analysis.

\section{SPS Deployment}

The SPS deployment schedule has not been broadly investigated. A comprehensive commercialization study is needed to say when and how much of our electrical energy might be contributed by SPS. This analysis could provide the cost comparison and system definition activities with information necessary for performing analyses and defining systems.

\section{Distributed Energy Systems}

The comparative assessment considers electrical generating technologies in much the same context of application that has occurred in the past. Currently there are discussions and analyses of the appropriateness of "distributed energy" sources. The thrust of this arrangement is to install many small sources, e.g., electrical generators, throughout communities, rather than employing a few large sources. These sources may perform more than one function, e.g., cogenerate useful heat and electricity. These technologies could, in the future, be an alternative to SPS technology. The economic 
evaluation of these technologies is difficult because of the many technological forms and conditions that are possible.

\section{Regional Aspects of the SPS}

The cost information that was assembled for the comparative assessment is not broken down by region, and therefore regional variations in cost of the various technologies could not be compared. Preliminary studies of SPS siting indicate that it may be difficult to site a rectenna in the East, because of the amount and characteristics of the land needed for the site. The possibility that a rectenna site might have to be remote from demand centers suggests that transmission systems may add to the cost of the SPS, but energytransmission aspects of the various technologies have not been assessed. An analys is of regional costs and varying transmission requirements would aid the suggested deployment study.

\subsection{HEALTH AND SAFETY*}

\section{2 .1 Introduction}

The increasing U.S. demand for energy and societal concern regarding technology-associated risks underlie the high priority of health and safety impact evaluation during assessment of alternative energy systems. Ideally, health and safety evaluations sum all risks associated with each system under comparison. However, this sort of evaluation is not currently feasible because of uncertainties surrounding both system designs and risk estimates. In addition, an evaluation based solely on a summing of impacts would o.oscure the differences between energy systems that result from different societal perceptions of "acceptable" risks, which are important considerations for the pol ic ymaker.

This section describes an assessment taxonomy and compares health and safety impacts from five energy systems: the satellite power system, combincd-cyclc coal, light watcr rcactor with fucl reproccooing, central terrestrial photovoltaic power stations, and fusion.

The assessment taxonomy consists of: (1) an identification of health and safety issues in each part of the energy system; (2) quantitative, or if limited by data availability, qualitative evaluation of impact severity; and (3) for each issue, an assignment of relative indices for impact severity and level of uncertainty. The framework for evaluation of issue impact and uncertainty includes both quantifiable issues and those potentially important but currently unquantifiable. The evaluation of unquantifiable issues can serve as a useful tool in identifying needed research.

Issue identification also allows for the comparison of the energy cycle components of each technology from fuel and raw materials extraction and component fabrication through electricity generation, waste disposal, and system

*The primary contents of this section are a summary of results in Ref. 48, which includes a more comprehensive list of basic references. 
decommissioning. Comparison of technologies on this level provides useful information regarding affected populations, duration of impact, and potential for impact mitigation.

In addition, the approach allows for comparisons between different categories of health and safety impacts with different perceived acceptabilities. A prime example of the need for comparing categories of impacts is the case of catastrophic events (defined in this study as single events resulting in over 1,000 deaths). Because of the engineered low $r$ isk of occurrence for these events, the number of expected deaths per year averaged over the lifetime of the plant may be lower than that from continuous low impact risks, but the public perception of the significance of these potential events may critically affect the viability of a technology. Categories of impacts addressed include public and occupational impacts; short-term and long-term effects; and accidents, disease, radiation, and catastrophic events.

\subsubsection{Issue Identification, Severity, and Uncertainty}

This preliminary study resulted in a listing of the major known and potential health and safety issues for each energy technology. The process of issue identification included deliberate efforts to limit the total number of issues for each technology to an easily comprehensible set of issues and to exclude impacts quantitatively negligible in comparison to other known impacts. For each issue, the severity of potential health and safety impacts was assessed within the limits of available data.

The principal measure of health and safety impact severity used in this preliminary assessment is the estimate of expected deaths per time period or event attributable to the energy system or phase of that. system. In addition to this quantit.ative measure, issues identified for each system were classified with impact severity (Table 4.13) and uncertainty (Table 4.14) indices. Table 4.13 defines the severity index on the basis of annual level of health and safety impacts averaged over a 30-year lifetime of a unit power plant $(1,000 \mathrm{MW})$.

Table 4.13. Severity Indices for Individual Health and Safety Issues

\begin{tabular}{llc}
\hline Hazard Category & $\begin{array}{c}\text { Level of Impact }(\mathrm{x}), \\
\text { Fatalities } / 1,000 \mathrm{MW} / \mathrm{yr}\end{array}$ & Severity Rating \\
\hline Quantifiable & \multicolumn{1}{c}{$\mathrm{x}>0.1$} & 1 \\
& $0.1>\mathrm{x}>0.01$ & 2 \\
Potential, but & $\mathrm{x}<0.01$ & $\mathrm{~A}$ \\
Unquantifiable & High (may be significant, & \\
& $\mathrm{x}>0.01)$ & B \\
& Low (probably insignificant, & \\
\hline
\end{tabular}


Table 4.14. Uncertainty Indices

\begin{tabular}{lcc}
\hline \multicolumn{1}{c}{ Description } & $\begin{array}{c}\text { Uncertainty } \\
\text { Index }\end{array}$ & $\begin{array}{c}\text { Severity } \\
\text { Rating } \\
\text { Options }\end{array}$ \\
\hline $\begin{array}{l}\text { Causal relationship and impact levels rela- } \\
\text { tively well established (e.g., coal mining } \\
\text { accidents) }\end{array}$ & 1 & $1,2,3$ \\
$\begin{array}{l}\text { Established but poorly quantified causal } \\
\text { relationship (e.g., low-level ionizing } \\
\text { radiation) } \\
\begin{array}{l}\text { Cause-effect association established, but } \\
\text { impact level estimates extremely variable } \\
\text { (e.g., ground water pollution, catastrophic } \\
\text { events) }\end{array}\end{array}$ & 2 & $1,2,3$ \\
\hline
\end{tabular}

In addition to defining severity indices on the basis of quantifiable impacts, the rating procedure in Table 4.13 also applies to issues that are unquantifiable. These latter issues are given an index based primarily on a qualitative understanding of the potential hazards--those for which established impact data are not available because of lack of sufficient operating experience in an existing technology or a lack of similarity between existing and future technologies. A ranking of non-negligible severity (A) defines a potential hazard in a reasonable operating scenario in which human interactions could result in a significant number of injuries or disease occurrences. A low potential hazard (B) implies an event of low probability of occurrence or limited impact.

To gain perspective on the relative societal implications of the health and safety issues within each of these severity categories, it is useful to compare the range of impact levels within the categories with other health and safety risks to which the general population is exposed. Since the U.S. electrical power consumption per $10^{6}$ persons is approximately $1,000 \mathrm{MW}, 49$ the units of fatalities/1,000 MW/yr can be considered equivalent to fatalities/yr/106 persons for purposes of comparison with other risks. (This is only true when risks are evaluated on the basis of the average for a generic population since the electricity users of a specific facility are not necessarily the group that incurs the risk from that facility.) This comparison, as illustrated in Fig. 4.11, indicates that the risks from air pollution, background radiation, saccharin, urban drinking water, and lightning, to which a large segment of the population is exposed, would all receive a "high" or "l" severity rating under the energy system issue categorization chosen.

The uncertainty assigned to each severity rating is based on the degree to which the cause-effect relationship of the hazard-impact has been established, as well as the reliability of the impact quantification or impact potential. Ratings assigned the lowest level of uncertainty (1) were those for which strong arguments could be made regarding the existence of a cause-effect relationship between existence of the hazard and occurrence of resulting impacts and for which the degree of impact was well-defined, 

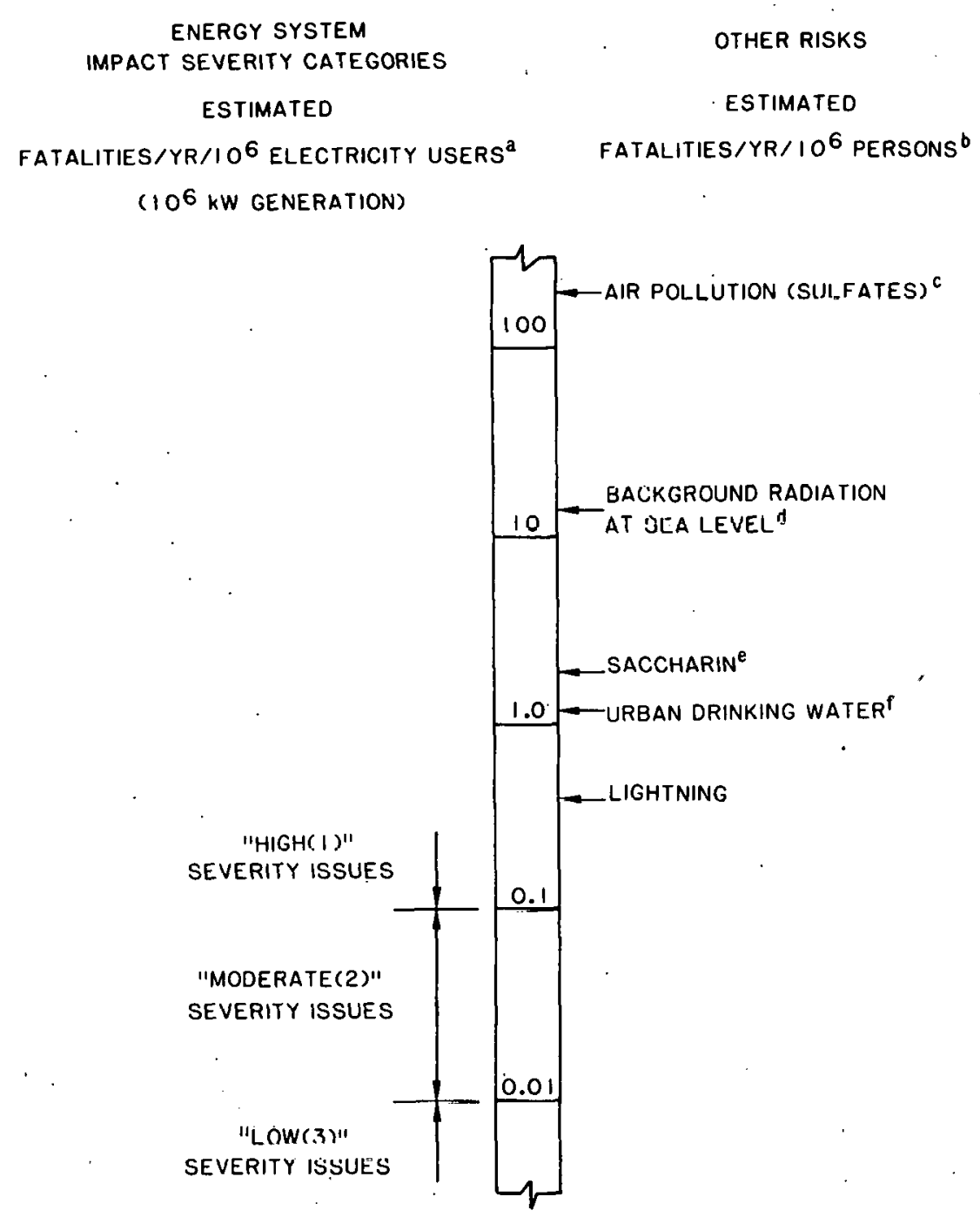

a) Estimated fatalities from electrical generation do not necessarily occur within users group.

b) From Ref. 50 .

c) Based on average U.S. exposure.

d) No. of cancers based on linear extrapolation of human epidemiological data.

e) No. of cancer's based on averagé U.S. consumption and linear extrapolation of animal data.

f) No. of cancers based on multistage extrapolation from animal data with Miami and New Orleans drinking water.

Fig. 4.11. Impact Severity Categories for Energy System Health and Safety Issues in Comparison to Risks from Other Causes 
primarily through historical data. Issues rated at higher uncertainty (2) were those for which cause-effect associations could be made but for which impact levels were unquantifiable. Issues for which cause-effect associations were evident, but for which quantification was extremely variable or lacking, were assigned the highest level of uncertainty ( 3 ).

\subsubsection{Issue Description and Comparison}

Major health and safety issues associated with each energy system are discussed in the following sections, which include diagrams indicating the parts of each system to which the issues relate and the relative severity and uncertainty of each issue. This discussion is concluded with a comparison of systems with regard to pertinent categories of health and safety impacts.

\subsubsection{Satellite Power System ${ }^{48}$}

The SPS health and safety issues are identified in Fig. 4.12. Due to the uncertain nature of the satellite power system (SPS) concept design and lack of experience of large-scale space projects using SPS-type technologies, estimation of the extent of many identified health and safety issues involves a great deal of extrapolation. However, an established data base 51-53 does exist for the technologies and processes needed to supply the large conventional material and service requirements (Issue 1 ) as defined in the current NASA contractor SPS reference design.2 Increases in both public and occupational health effects resulting from SPS conventional material and service requirements are expected to account for a significant portion of the total SPS health impacts.

A high degree of uncertainty is attached to health and safety impacts of other identified issues in Fig. 4.12. Despite this uncertainty, several issues appear to pose nonnegligible threats to public and occupational health and safety.48 The impact on human health from long-term exposure to low-level ( $1 \mathrm{~mW} / \mathrm{cm}^{2}$ ) microwave radiation* (Issue 8 ) is currently not well understood. Studies suggest that chronic exposure may result in teratological, reproductive, genetic, Immunological, and neurological impacts. 54.

The impacts of production of photovoltaic cells (Issue 2) in sufficient quantity to meet SPS requirements are potentially high but uncertain due to the experimental nature of current production 55 and the projected use of toxic gallium aluminum arsenide (GaAlAs) cells. ${ }^{2}$

Occurrence of a catastrophic event involving propellant or guidance system malfunction of transport vehicles (Issue 3 ) could result in a significant number of highly visible safety impacts.48 Also of concern are more continuous, less immediate impacts from noise and atmospheric emissions by transport vehicles54 (Issue 4 ).

Other identified issues received low severity ratings due to potential mitigation strategies that could keep health risks at low levels. For such

* Microwave radiation is nonionizing; nuclear radiation is ionizing. 


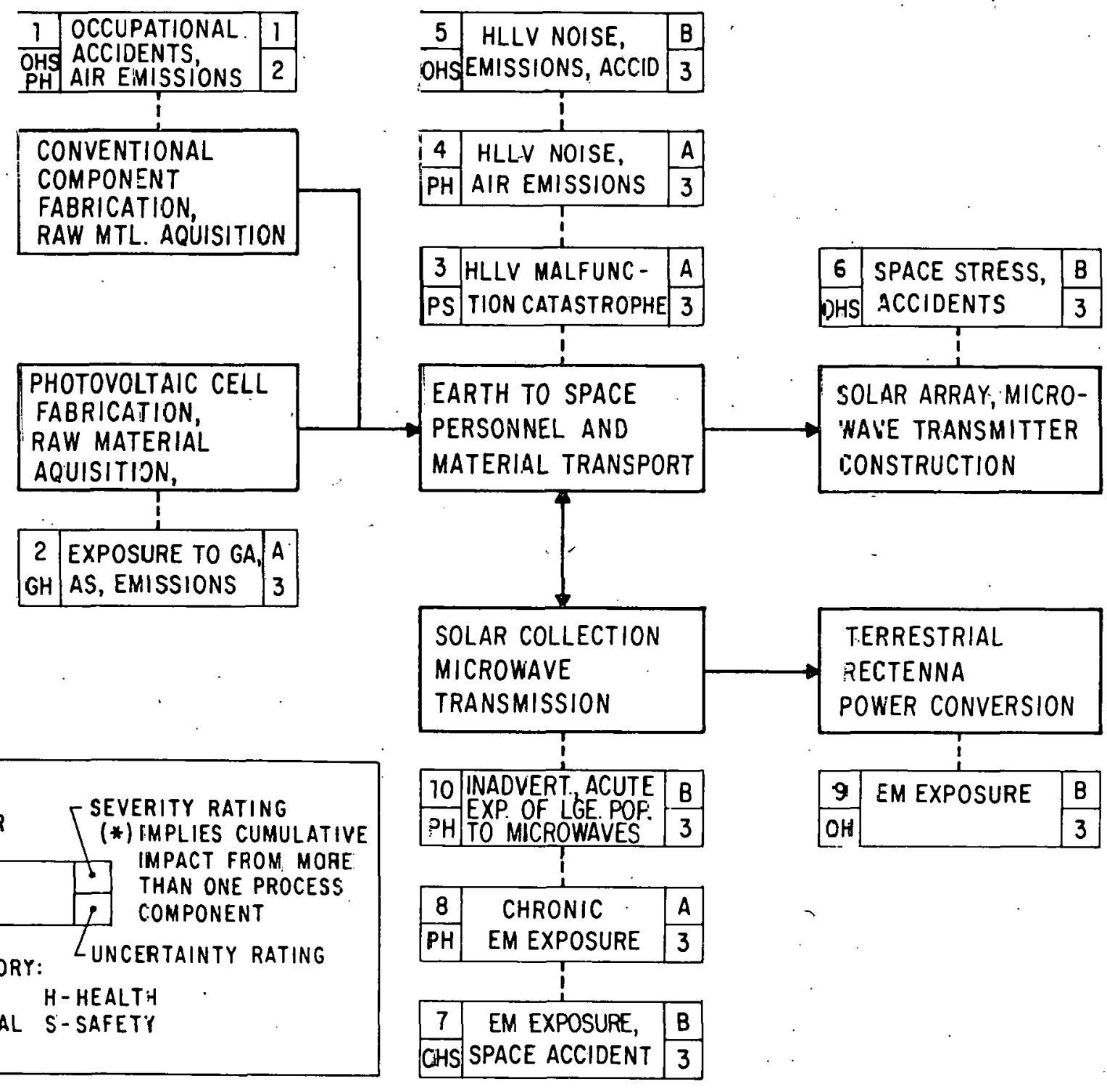

Fig: 4.12. Satellite Power System: Health and Safety Issue Identification (Source: Ref. 48) 
issues, procedures such as personnel screening, use of safety.equipment, limitation of exposure periods, and continuous maintenance of SPS system components would minimize risk.

Issue 10, inadvertent or clandestine acute exposure of large populations to radiation, addresses an event with potentially significant adverse impacts, but for which the probability of occurrence is very low with the current reference design using a retrodirective phase-control system and ground-based beam monitor to detect beam movement. 48 The combination of safety inherent in the current design with uncertainty as to the final design warrants a severity rating of (B) for this issue.

\subsubsection{Light Water Reactors with Fuel Reprocessing ${ }^{48}$}

Health and saffety issues associated with light water reactors (LWRs) appear in Fig. 4.13. As with CG/CC, imany health and safety issues associated with light water reactors are well-established because the technology has been in commercial use for 20 years. 56,57 The addition of fuel reprocessing introduces uncertainty to the impact estimates.

The major quantifiable issues of this technology pertain to uranium mining and milling (Issues 1 and 2). Uranium miners experience roughly the same risk of physical hazard as do coal miners. 58 Low-level radiation exposure of occupational and public populations resulting from mining and milling is another factor contributing to the severity rating. 59 Uranium miners and handlers are exposed to uranium daughter products that are known to present carcinogenic risks.60 Radiation-induced lung cancers have been observed in underground miners exposed to radon decay products. Ore tailings also contain measurable quantities of radium and radon that reach the public through atmospheric and aquatic disposals. 61

Other major issues associated with light water reactors are not as easily quantifiable. The primary issue relating to plant operation and maintenance is that of a catastrophic event (Issue 8).62-64 Although the probability of a core meltann or significant release of radiation is projected to be minimal, any such occurrence would be highly visible and would significantly affect the LWR industry. Similar situations are addressed by Issues 11 and 5 , the diversion of plutonium for weapons, 61 and the potential exposure of workers and the public to hydrogen fluoride during fuel enrichment and fabrication.65,66 Although the probability of occurrence of either event is low and can be minimized by preventive procedures, the possibility of such an occurrence with accompanying impacts is a significant issue potentially limiting the LWR.

\subsubsection{Coal-Gasification/Combined-Cycle ${ }^{48}$}

The health and safety issues associated with coal-gasification/combined cycle (CG/CC) are 1llustrated in Fig. 4.14. Because of the maturity of coal technology for electricity generation, health and safety impacts can be quantitatively estimated for many issues. However, the addition of low-Btu gasification increases the uncertainty of quantified impacts. 

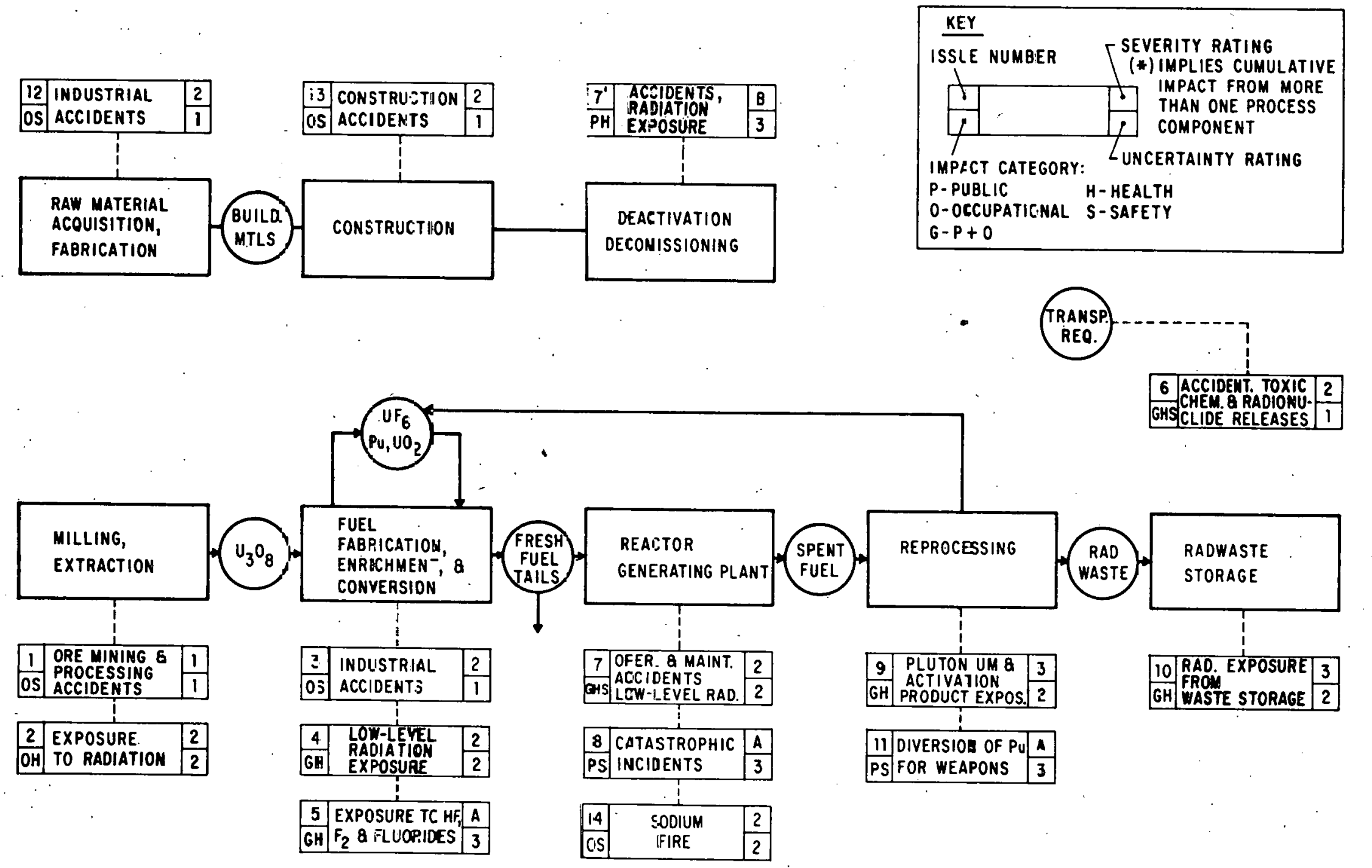

Fiz. 4.13. Light Water Reactors with Fuel Reprocessing: Health ard Safety Issue Identification (Source: Ref. 48) 


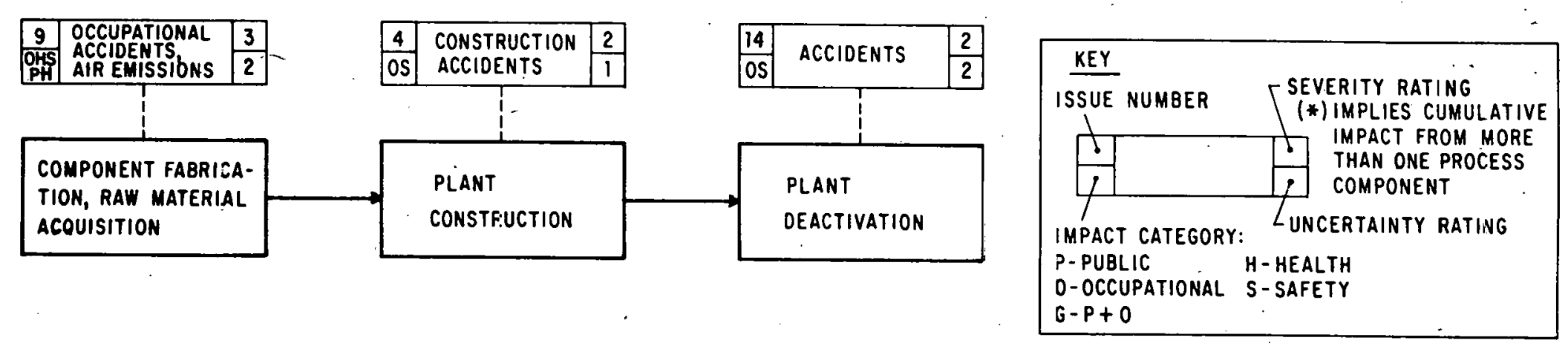

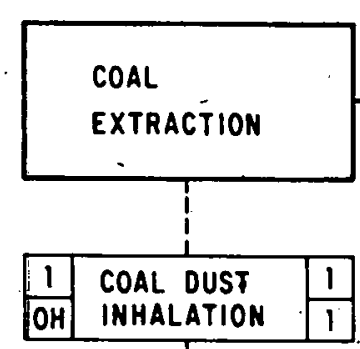
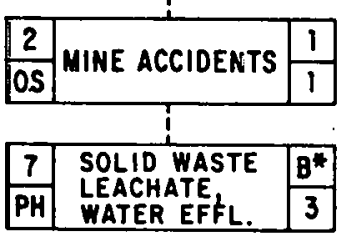
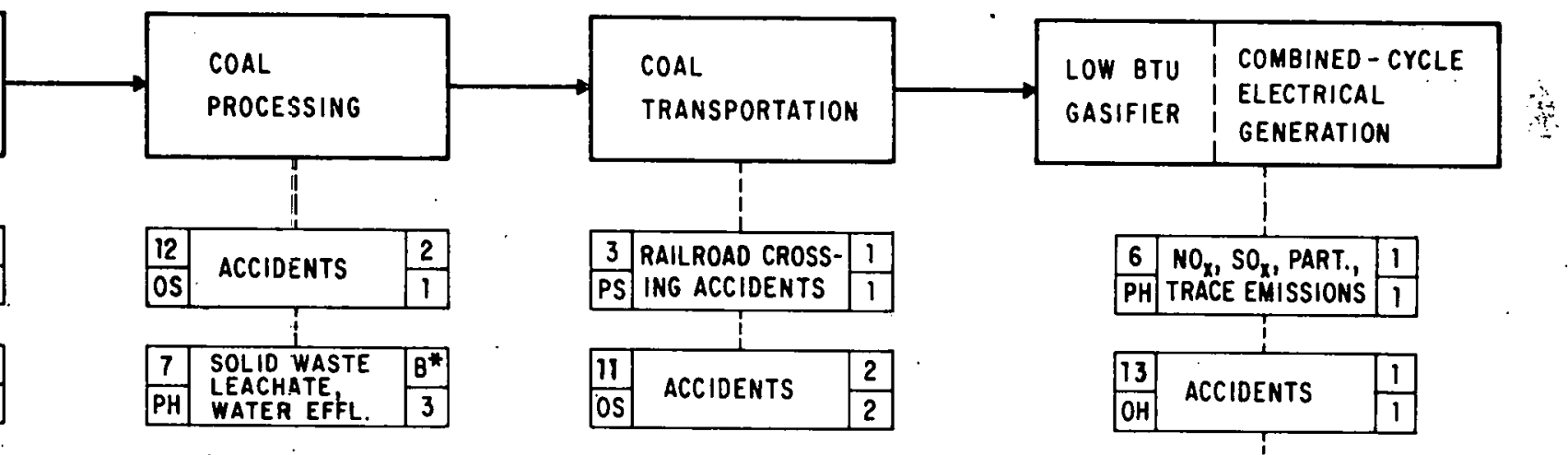

$6 \mathrm{NO}_{\mathrm{x}}, \mathrm{SO}_{\mathrm{x}}$, PART., 1

PH TRACE EMISSIONS

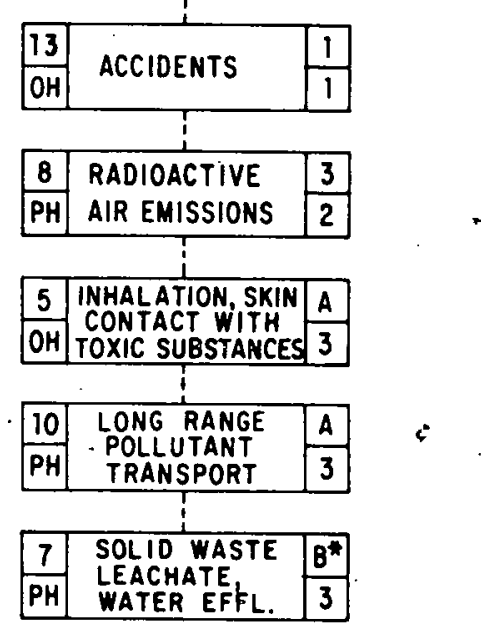

Fig. 4.14. Caal Gasification/Combined Cycle: Health and Safety

Issue Identification (Source: Ref. 48) 
One major quantifiable issue (Issue 6) addresses near-field (within $80 \mathrm{~km}$ ) exposure to atmospheric emissions such as $\mathrm{NO}_{\mathrm{X}}$, $\mathrm{SO}_{\mathrm{X}}$, particulates, and trace elements during coal plant operation. The toxic effects of these substances on populations exposed to them are well documented.67,68 However, considerable uncertainty remains about the actual impact mechanisms and the role of synergistic effects from specific combinations of pollutants that would be emitted from new combined-cycle technologies. This uncertainty is compounded by the lack of information regarding public exposure to transformation products of emissions transported over long distances (Issue 10 ).

Next to near-field air pollutant effects, the largest quantifiable public impact of major importance would be from railroad grade-crossing accidents associated with coal transport (Issue 3 ). $67,69,70$

Major quantifiable occupational impacts result from coal extraction (Issues 1, 2) 52,67,71,72 and plant operation and maintenance (Issue 13).67 Accident risks and exposure to coal dust are the major sources of impacts to coal miners. The estimate of occupational accident risk associated with generating plant operations was large enomgh (nver 0.1 deaths/yr) to place this issue into the category with the highest severity rating, although the accident estimates are considerably lower than those for coal mining.

The preprocessing, gasification, and combustion of coal in the combined-cycle facility result in various products that $c$ an be carcinogenic and toxic if inhaled or in contact with the skin over extended periods.73-75 The potential concentrations of these substances is uncertain but of sufficient concern to warrant an A severity rating (Issue 5).

\subsubsection{Central Terrestrial Photovoltaic Systems 48}

The major health and safely issues surrounding terrestrial photovoltaic (TPV) systems are illustrated in Fig. 4.15. Five major health and safety issues have been identified for TPV systems; impacts of three are currently quantifiable.

The quantifiable issues $(2,3,4)$ address occupational impacts of conventional material requirements, construction activities, and operation and maintenance procedures. Several studies 76,77 have applied accident and injury rates from these economic sectors to the requirements of TPV systems. Estimates of impact severity vary widely, but worst case projections of impacts nn Llıe vccuparlonal population justify classification of these issues as having a geverity ratiug of 1 .

Currently unquantifiable issues of high severity include the procurement of raw materials and the manufacture of photovoltaic cells (Issue 1). Although some experience with silicon cells has been documented, primarily through the space program, what is known about worker health and safety and public exposure to toxins is based on applications of limited scale. The proposed use of GaAlAs cells further increases the uncertainty of health impact quantification. The relative risk of some workers involved in TPV construction activities is anong the highest occupational risks in the U.S.52 In addition, environmental effluents emitted during cell production contain 


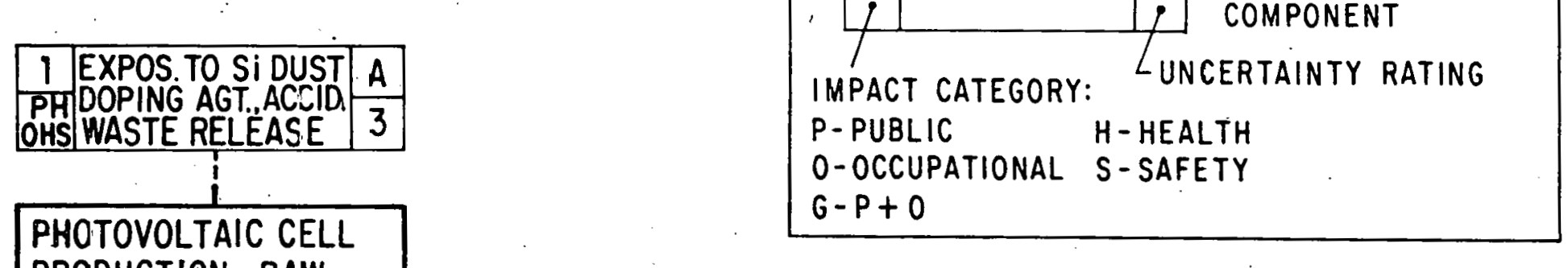

PRODUCTION, RAW

MTL. EXTRACTION

AND PROCESSING

CONVENTIONAL MTL.

EXTRACTION PROCESS,

FABRICATION AND

TRANSPORTATION

I

CONSTRUCTION OF
PHOTOVOLTAIC CEN-
TRAL POWER STATION

OPER. AND MAINT. OF
PHOTOVOLTAIC CEN-
TRAL POWER STATION

DISPOSAL/RECYCLING OF SPENT

PHOTOVOLTAIC CELLS
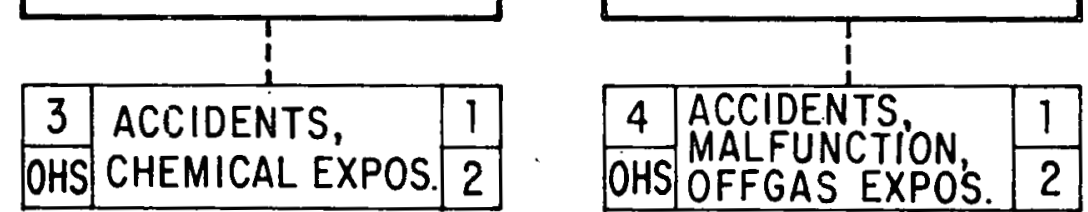

\begin{tabular}{|c|l|l|}
\hline 5 & EXPOSURE TO & A \\
\cline { 1 - 1 } & AS, GO, BIO- & GH \\
\cline { 1 - 3 } & ACCUMULATION & 3 \\
\hline
\end{tabular}

\begin{tabular}{|l|l|l|}
\hline 2 & ACCIDENTS, HAZ- & 1 \\
\hline PH & ARDOUS MTL. 8 & 2 \\
OHS & EMISSION EXPOS. & 2 \\
\hline
\end{tabular}

Fig. 4.15. Central Terrestrial Photovoltaic System: Health and Safety Issue Identification (Source: Ref. 48) 
potentially toxic substances. Large-scale development of TPV systems could result in the significant release of these toxic substances with subsequent public health risk. 2,55

Issue 5, disposal and/or recycling of spent photovoltaic cells, is another issue for which health and safety impacts are of high potential severity but difficult to quantify. Doping agents (As and $G a$ ) in advanced photovoltaic cells are toxic. Although TPV systems are projected to have 30 -year lifetimes, ${ }^{2}$ cell lifetimes are projected to average five years; 55 thus six replacements of enough solar cells to produce 1,000. MW (peak) will contain $1.27 \times 10^{7} \mathrm{~kg}$ of GaAlAs polycrystal. There will be a need to dispose of or recycle large amounts of potentially toxic material, thus increasing occupational and public risk of exposure to toxics suhstances.

\subsubsection{Fusion ${ }^{48}$}

The identified health and safety issues surrounding. fusion appear in Fig. 4.16. Because of the experimental nature of the technology, impact severity estimates are not well quantified and are highly uncertain. The health and safety issues of a fusion system can be divided into those resulting from radiation and those without risk of radiation exposure. Radiation issues are primarily those associated with hazards of fuel and component preparation, fuel transportation, plant operations, and waste disposal.

Fusion is often contrasted with fission and described as a selflimiting process without the problem of radioactive waste disposal. Although the fusion reaction will not release waste products from fuel use, it does not preclude radioactive wastes from non-fuel system components such as artivation products in the first wall of the reactor. Component failure 78 (Issue 11) and operation accidents78-80 (Issue. 14) can result in potentially severe occupational and public exposure. The releaoe of tritium especially under severe accident situations could also pose a potential general héalth hazard.81

Other potentially severe health issues relate to occupational exposure and include toxic exposures during fuel processing and fabrication of system components $78,82,83$ (Issues 3 and 5). Hydrogen sulfide exposure during deuterium extraction and acid leaching of lithium ore can result in health impacts to workers in such operations. 78 Beryllium, an identified workplace hazard, will be used in the fusion vessel blanket for enhanced neutron production. Workers likely to be exposed to this metal or its compounds during fabrication must be protected from adverse effects.

\subsubsection{Technology and Impact Category Comparisons}

A side-by-side summary of the energy systems under consideration is provided in Fig. 4.17, with most to least develuped technologies listed from left to right. The uncertainty categories are illustrated in the upper right of the figure, which shows a decreasing level of well-quantified impacts for less-developed technologies. However, an energy system ranking on the basis of these death risks may lead to misleading conclusions because of the uncertainty in the quantification. As illustrated, the quantified impacts from the 

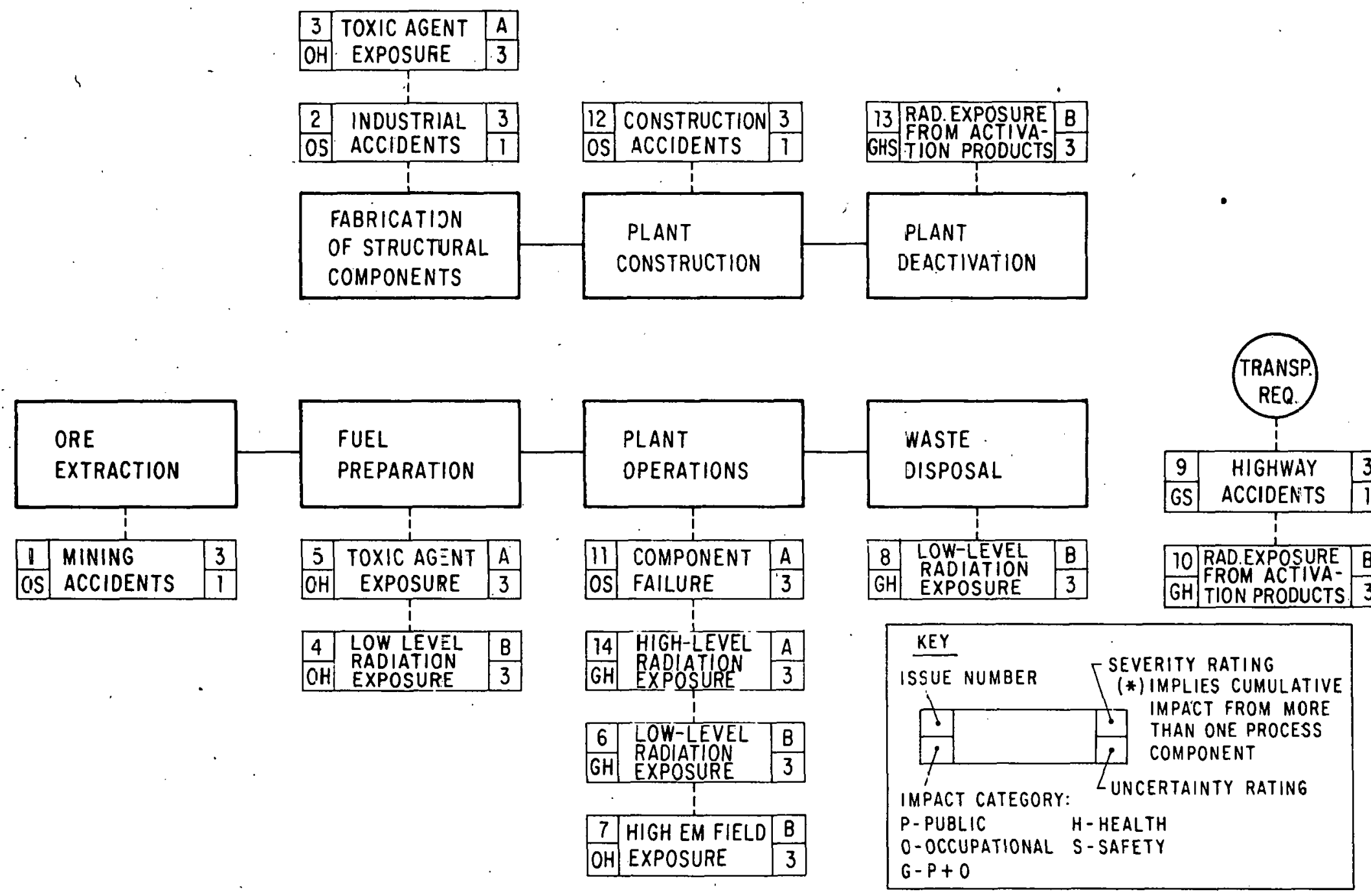

Fig. 4.16. Fusion: Fealth and Safety Issue Identification (Source: Ref. 48) 


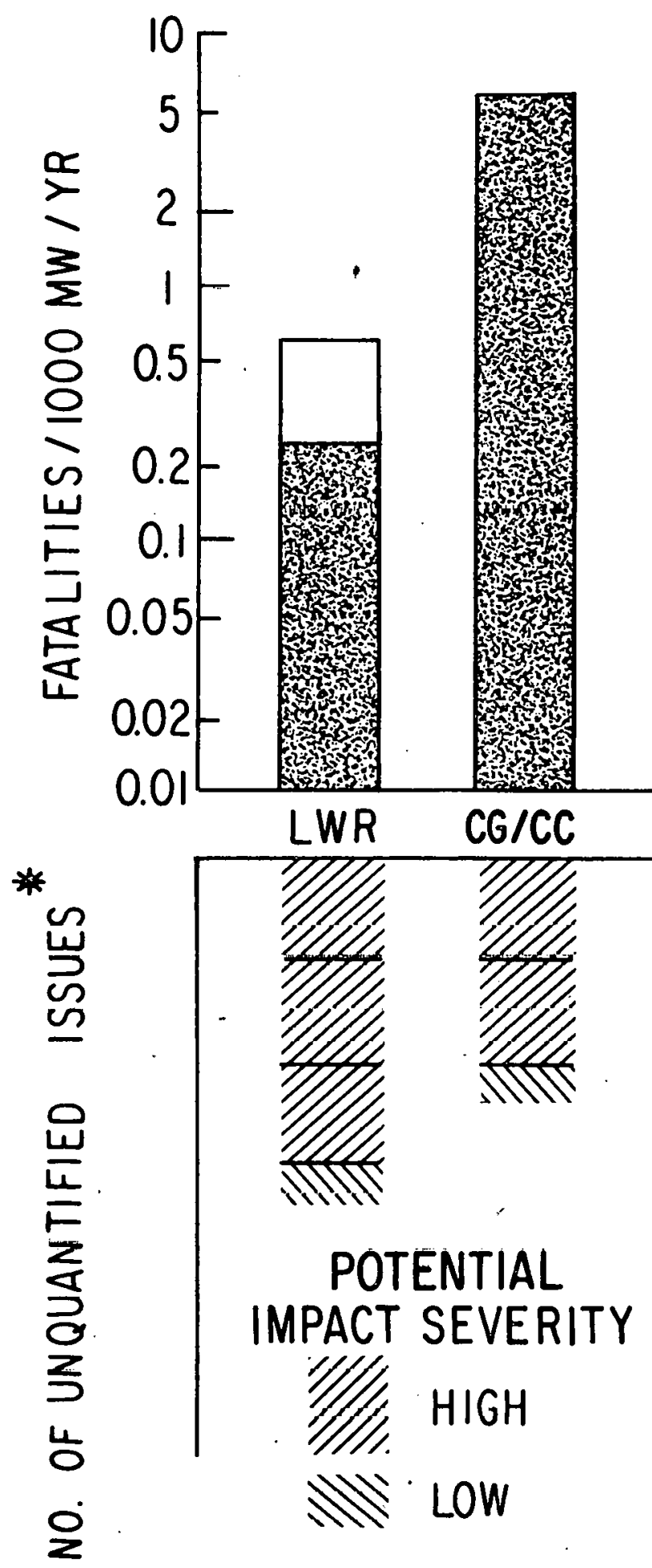

UNCERTAINTY
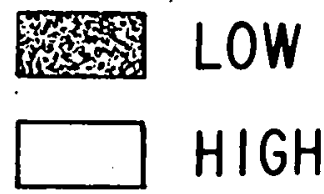

F1g. 4.17. Total Impacts (Public + Occupational) of the Five Energy Systems

*Included to qualitatively indicate importance of unquantifiable issues. Cannot be used for quantitative comparisons. Includes potential catastrophic events. 
terrestrial photovoitaic system and the SPS are much more uncertain than those from coal and light water reactor systems. For example, the major quantified impacts for the terrestrial photovoltaic system are largely due to occupational hazards from construction and maintenance of the large arrays of solar collectors--activities for which no precedents exist.

The uncertainties of health and safety issues that were identified as potential but considered unquantifiable present an equal or even greater difficulty in establishing an energy system ranking based on the health and safety considerations in this preliminary assessment. Figure 4.17 also provides a qualitative perspective on the potential role of currently unquantified issues by illustrating the number of these issues for each technology. The far-term SPS and fusion systems, which have the least reliable quantified impacts, also have the most unquantifiable issues. Both the number of issues and the qualitative range of severity of each issue are indicated. Although the enumeration of unquantified issues represented in Fig. 4.17 is useful, for indicating their potential importance, this enumeration cannot and should not be used at this stage of analysis for quantitatively determining relative impact magnitudes.

Figure 4.18 shows a similar comparison of the five technologies under comparison with regard to quantifiable impacts on the non-occupational or public sector. The relatively high level of quantified public impacts for the CG/CC coal technology is related to air pollutants and coal transport. Again the uncertainties prohibit final rankings at this juncture. SPS and fusion, which have the lowest quantified impacts, have the largest number of unquantified issues.

Figure 4.19 similarly illustrates the component production and facility construction impacts averaged over a 30-year plant lifetime and demonstrates the more capital intensive nature of the solar technologies in comparison to the coal and light water reactor technologies.

A major factor in the determination of the future viability of a new technology may be the real or perceived potential for a catastrophic event, defined as a short-term incident potentially resulting in 1,000 or more eventual deaths. For the systems considered, potential catastrophic events identificd are:

- Coal/combined cycle: None.

- Light water reactor:

Core meltdown, breach of containment.

Fuel diversion, terrorist bomb.

- Terrestrial photovoltaic: None.

- Satcllite Power System:

Space transport or LEO vehicle crash into urban area.

- Fusion:

Acute radiation exposure from explosive rupture of fusion reactor vessel. 


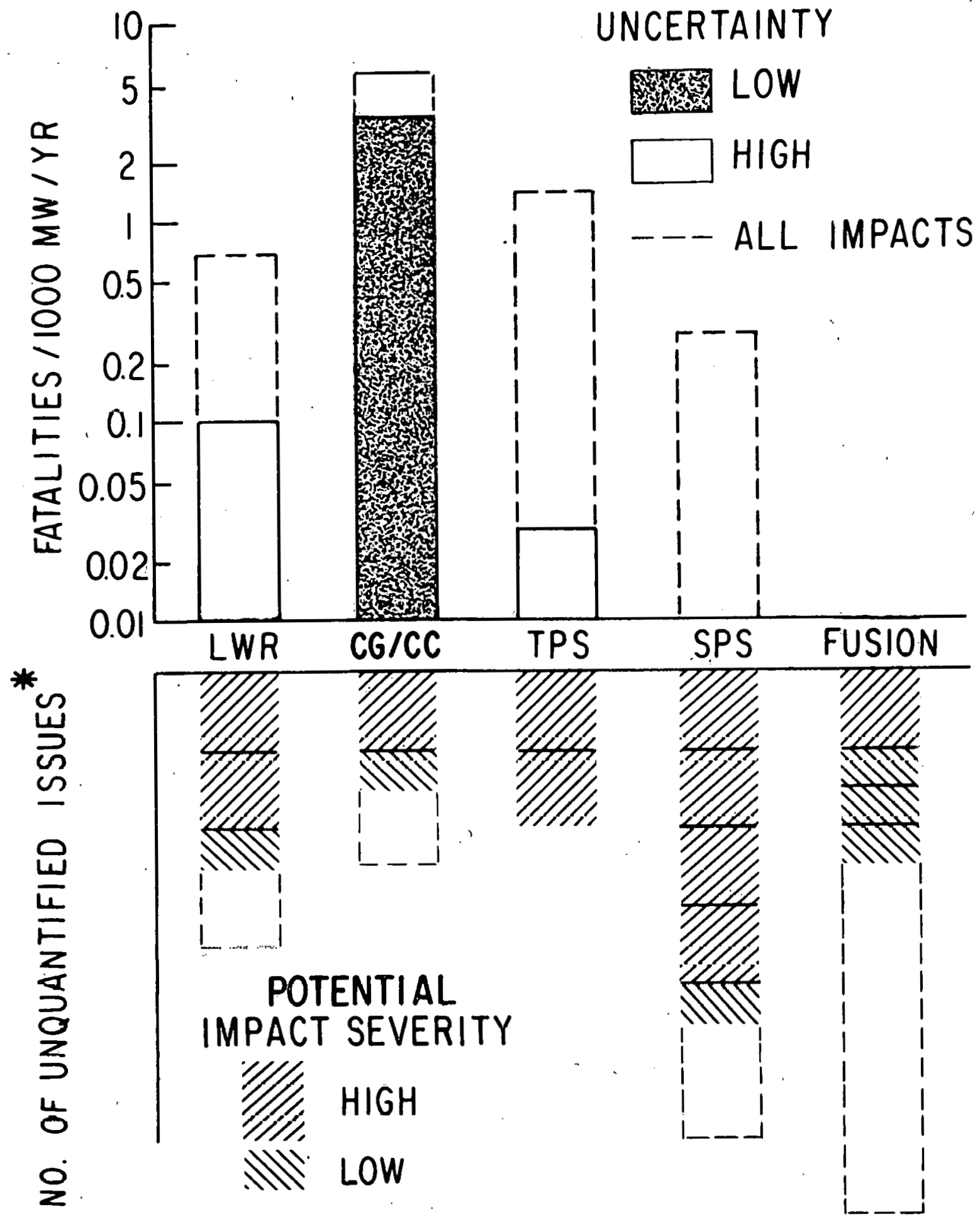

Fig. 4.18. Public Impacts of the Five Energy Systems

*Included to qualitatively indicate importance of unquantifiable issues. Cannot be used for quantitative comparisons. Includes potential catastrophic events. 


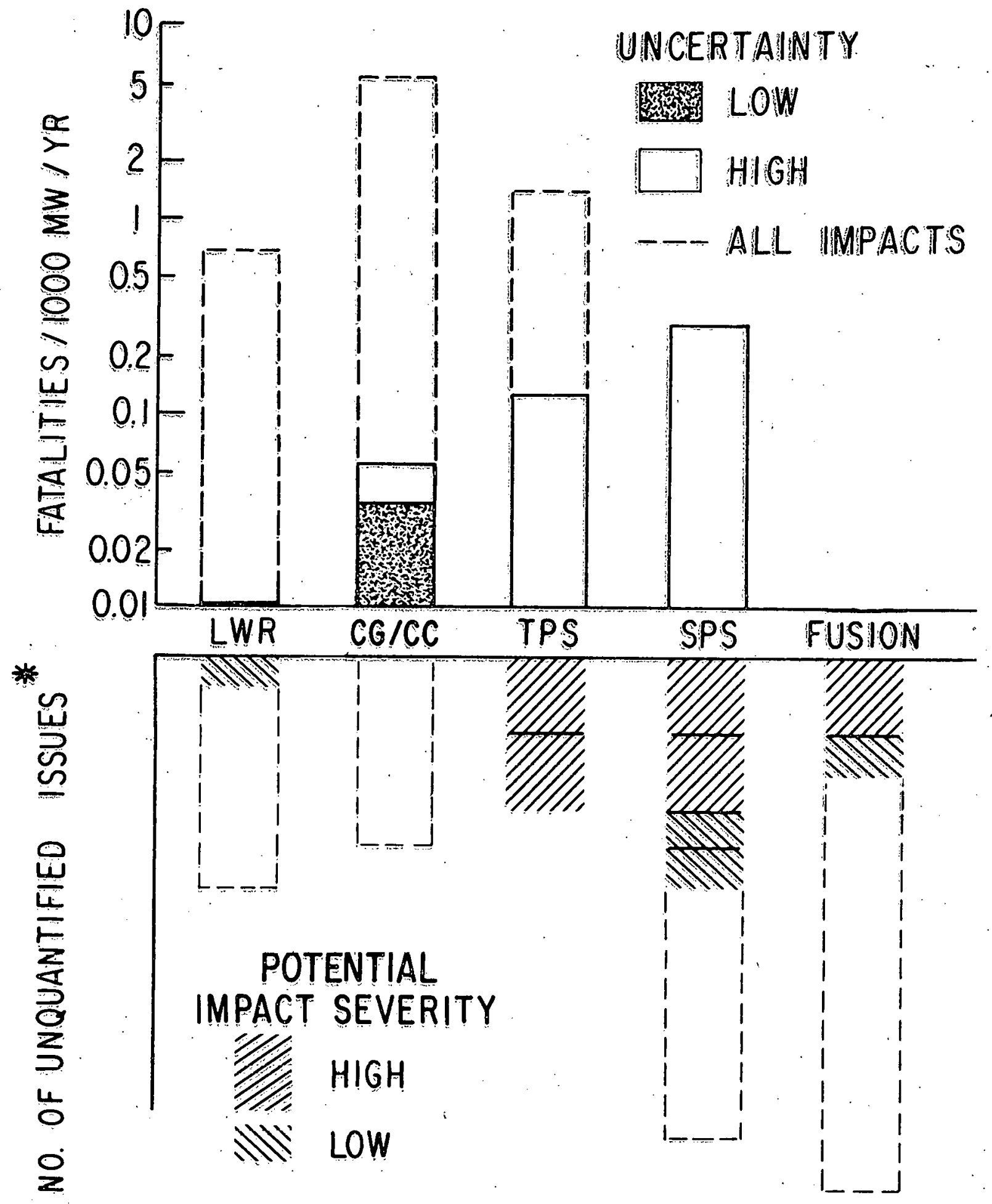

Fig. 4.19. Impacts of Component Production and Facility Construction of the Five Energy Systems

*Included to qualitatively indicate importance of unquantifiable issues. Camot be used for quantitative comparisons. Includes potential catastrophic events. 
Because of the difficulty in establishing probabilities of occurrence, these events were included as unquantifiable issues. Even for events for which estimates of probabilities of occurrence and deaths per occurrence are available, the impacts averaged over plant lifetime may be perceived to have different relative importance in relation to other continuous risks of comparable magnitude. These catastrophic events are thus expected to continue to require separate evaluation in health and safety comparisons.

\subsubsection{Gaps in Information and Future Study}

The health and safety impact estimates compiled in this preliminary assessment are based primarily on those developed in other studies. Gaps in available health and safety impact definitions are reflected in the number of unquantitiable issues and the number of quantifiable issues with high levels of uncertainty regarding impact severity. For issues concerning currently non-commercialized technologies, these gaps are caused by lack of sufficient system definition or lack of similarity to existing technologies, precluding extrapolation. Discrepancies in impact estimates that exist for commercialized technologies include uncertainties about waste disposal techniques, the probabilities of major catastrophic events, and cumulative effects of lowlevel exposures of large populations.

Subsequent analyses should consider in more detail the assumptions on which these analyses were based. Revisions to the estimates will be made as information is updated through ongoing research. Whereas the preliminary assessment focused on identifying death risks, the next level of analysis should be more comprehensive and should include person-days lost in nonfatal accidents and disease.

This preiliminary assessment addressed the health and safety impacts from nominal energy generation systems. The evaluation of health and safety impacts associated with particular system deployment patterns may be a more realistic basis for comparison. Such an analysis would account for the effects of achievable load factors within a utility system and therefore could include the analysis of health and safety impacts from required back-up and storage systems.

\subsection{ENVIRONMENTAL WELFARE EFFECTS}

\subsubsection{Introduction}

There are several types of effects from environmental degradation that are not directly related to public or occupational health and safety. These will be referred to as environmental welfare effects, since they concern the well-being of individuals. For example, deterioration of building materials from $\mathrm{SO}_{2}$ emissions, reduced crop productivity due to water pollution, and aesthetic impacts such as plume blight are considered. This preliminary evaluation of coal, nuclear (LWR), and SPS (GaAlAs solar cells) energy supply systems identifies the extent and severity of these welfare effects and 
develops a set of priority effects that require more in-depth analysis. Specifically excluded from this category are effects on health and safety, natural biological systems, resource depletion (including direct land and water use), and social and economic dislocations. Conditions following accidents were also not included in this study.

The sequence 84 for determining the environmental welfare effects of each energy technology begins with an examination of the various activities involved in each fuel cycle, beginning with the extraction of the resource and extending to the delivery of electricity to a utility grid. These activities result in environmental impacts such as noise and air and water emissions. In turn, the environmental impacts could result in welfare effects such as property damage, climatic change, interference with other activities, and aesthetic disturbances. This activity-impact-effect chain is illustrated in Fig. 4.20. The structure is used for categorizing the impacts and effects of the various activities in the fuel cycle.

The physical environmental impacts and their effects caused by the various activities within the coal, nuclear, and SPS technologies are listed in Tables 4.15., 4.16, and 4.17, respectively. Since this is a preliminary assessment, these tables are not exhaustive. Rather, they serve to identify the major or the most probable impacts.

\subsubsection{Comparative Impacts}

The welfare effect of each energy-related activity is examined in the context of the additional burden imposed on a community by that activity. Typical facility sizes -- for a mine, processing plant, or power plant -are used whenever possible as a basis for determining local welfare effects (the assumed facility sizes represent current opinion regarding the most likely unit sizes to be constructed in the near future). The welfare effects are not scaled to a common metric, such as cost or impact per $1,000 \mathrm{MW}$ of electrical capacity. Use of a common metric tends to obscure information because of the need to introduce various assumptions in converting impacts to a single unit of measure. The approach used in this assessment takes into account the fact that small, dispersed power plants often have smaller local welfare effects than would a large, centralized facility, even though the quantity of emissions per megawatt of electricity generated may be smaller for the larger facility. At the same time, it is recognized that many minor impacts may have a cumulative impact that could equal or exceed a major impact from a single, large facility. Other assumptions that underlie this analysis are that all activities use advanced pollution control technology representative of newer facilities and that facilities operate routinely (that is, without accidents).

The environmental welfare impact of each activity was quantified by the magnitude of some physical residual (e.g., noise level), and its capacity for mitigation was evaluated. It is thought that this approach provides a qualitative judgment that reflects the more recent trends in emissions and anticipated effects. Direct comparison between technologies tends to obscure the welfare issues associated with each energy technology and was therefore avoided. 


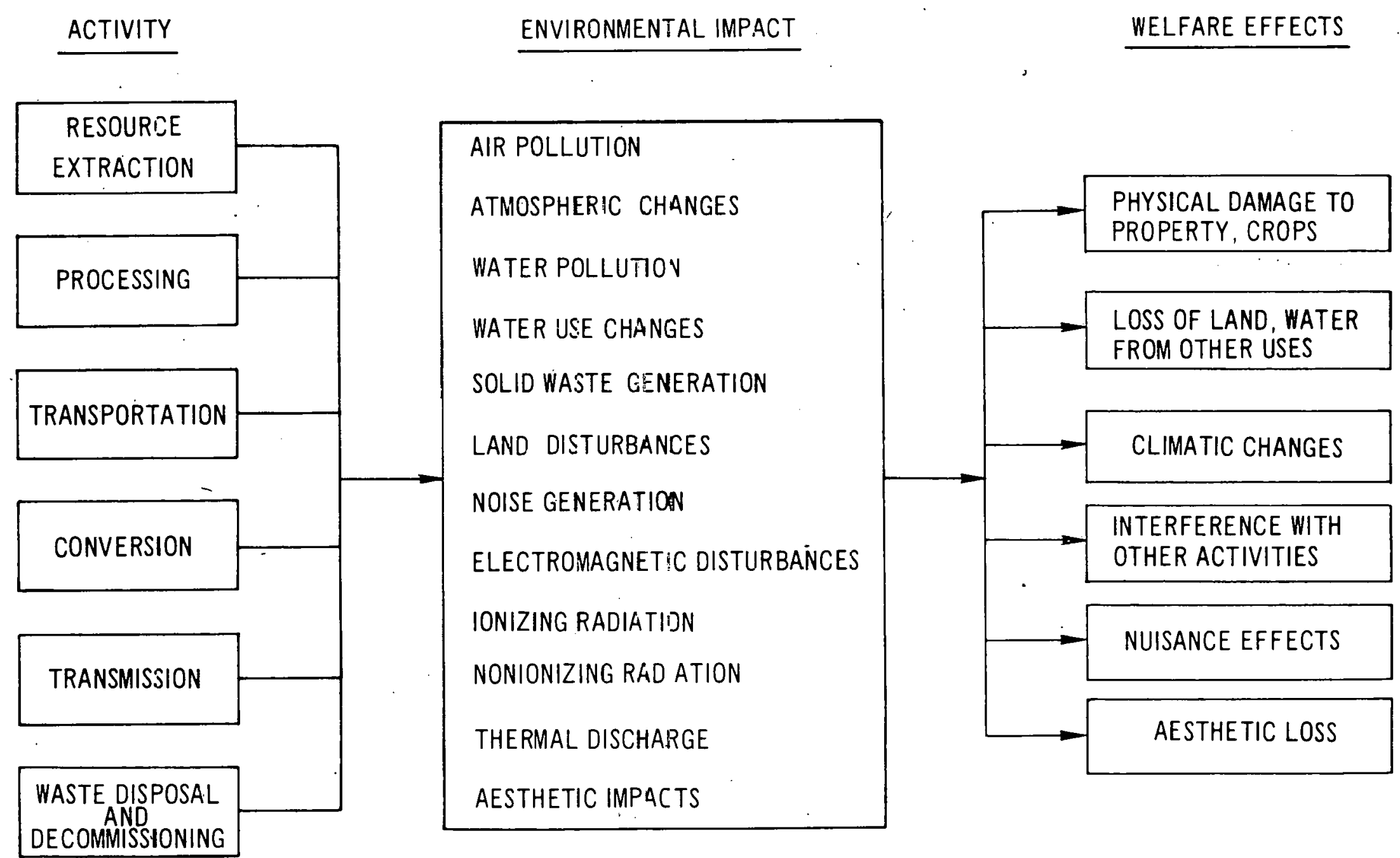

Fig. 4.20. Pathway of Energy Activities, Impacts, and Effects 
Table 4.15. Welfare Effects of Coal-Combustion Fuel Cyclea

\begin{tabular}{|c|c|c|}
\hline Environnental Impact & Activitles Involved & Welfare Effects \\
\hline Alr Pollution & $\begin{array}{l}\text { llining } \\
\text { Processing } \\
\text { Transportation } \\
\text { Power generation }\end{array}$ & $\begin{array}{l}\text { Emissions of } \mathrm{SO}_{2} \text { and } \mathrm{NO}_{x} \text { from power generation } \\
\text { can lead to actd rainfall, which can reduce crop } \\
\text { yield and remove lakes or rivers from commercial } \\
\text { or recreational use. Emissions of } \mathrm{SO}_{2} \text { and particu- } \\
\text { lates can cause or augnent material darage and reduce } \\
\text { crop yields. Secondary particulates can finpair visi- } \\
\text { bility. }\end{array}$ \\
\hline Atmospheric Changes & Power generation & $\begin{array}{l}\text { Injection of large amounts of } \mathrm{CO}_{2} \text { and other green- } \\
\text { house gases into the atmosphere may promote global } \\
\text { warning, with effects on precipitation, agricultural, } \\
\text { and ocean levels. Particulate emissions may also } \\
\text { play a minor role in climatic change. }\end{array}$ \\
\hline Thermal Discharges & Power generation & $\begin{array}{l}\text { Cooling tower operation can increase local fogging } \\
\text { and icing, with effects on visibility, traffic, and } \\
\text { convenience for nearby residents. cloud and precipi- } \\
\text { tation augnentation is possible but should be alnor, } \\
\text { with little effect on crop productivity. }\end{array}$ \\
\hline Water pollution & $\begin{array}{l}\text { lining } \\
\text { Processing } \\
\text { Power generation }\end{array}$ & $\begin{array}{l}\text { Discharges of acids, dissolved solids, suspended } \\
\text { solids, and other chemicals can degrade drinking } \\
\text { water supplies, contaminate waterways, lower crop } \\
\text { productivity because of acidified irrigation, or } \\
\text { groundwater, and reduce comnercial and recreational } \\
\text { use of streans and lakes. }\end{array}$ \\
\hline Water Use & $\begin{array}{l}\text { llining } \\
\text { Processing } \\
\text { Power generation }\end{array}$ & $\begin{array}{l}\text { lining can disrupt water flow patterns. Cooling } \\
\text { needs during power production require extensive } \\
\text { amounts of water if evaporative systems are used. } \\
\text { Both impacts can conflict with downstream and } \\
\text { conpeting uses. }\end{array}$ \\
\hline Solid Waste & $\begin{array}{l}\text { llining } \\
\text { Processing } \\
\text { Power genération }\end{array}$ & $\begin{array}{l}\text { Demand for disposal sites can be increased. Land } \\
\text { use, value, and productivity can be reduced by over- } \\
\text { burden and refuse from tilining and processing, ash } \\
\text { and scrubber wastes, and by hazardous trace retals } \\
\text { from power generation. }\end{array}$ \\
\hline Land Use Disturbance & $\begin{array}{l}\text { llịing } \\
\text { Processing } \\
\text { Transportation } \\
\text { Power generation } \\
\text { Transmisston }\end{array}$ & $\begin{array}{l}\text { Surface mining and power generation (waste disposal) } \\
\text { remove land from alternate uses; reclained land way } \\
\text { be less productive agriculturaliy than before mining. } \\
\text { Subsidence of land over underground wines can reduce } \\
\text { land yalues; danage crops, buildings, and livestock; } \\
\text { rupture pipes; and disrupt drainage. Coal process- } \\
\text { ing can contaminate and lower value of surround- } \\
\text { ing land. Transportation and transmission land re- } \\
\text { quipements are significant and limit other uses of } \\
\text { the land. }\end{array}$ \\
\hline $\begin{array}{l}\text { Elect romagnet ịc } \\
\text { Distur bances }\end{array}$ & Transmission & $\begin{array}{l}\text { IIgh intensity magnetic fields around transmission } \\
+1 \text { nes can cause radio and TV interference in fringe } \\
\text { reception areas. }\end{array}$ \\
\hline Ionizing Radiațion & Power generation & $\begin{array}{l}\text { Small quantities of radioactive materials are emitted } \\
\text { during coal combustion. Welfare effects of these } \\
\text { emissions, which are uncertain, include ef fects of } \\
\text { long-term exposure of crops and ilvestock to radiation. }\end{array}$ \\
\hline Noise & $\begin{array}{l}\text { Mining } \\
\text { Transportation } \\
\text { Power generation } \\
\text { Transmisston }\end{array}$ & $\begin{array}{l}\text { Welfare impacts of nolse generation from most coal- } \\
\text { rclated activities are rolativoly minor due to the } \\
\text { remote locations of the operations. Audible hum from } \\
\text { high-voitage transmission lines nay occur. }\end{array}$ \\
\hline $\begin{array}{l}\text { Aesthetic } \\
\text { Disturbances }\end{array}$ & $\begin{array}{l}\text { llining } \\
\text { Processing } \\
\text { Transportation } \\
\text { Power generation } \\
\text { Transmission }\end{array}$ & $\begin{array}{l}\text { Visual impacts will occur from mines, talling piles, } \\
\text { power piants, stack plumes, and transmission cors } \\
\text { rịdors. }\end{array}$ \\
\hline
\end{tabular}

a Ma in sources inclucude Refs. 84,85-91. 
Table 4.16. Welfare Effects of Nuclear Power Generationa

\begin{tabular}{|c|c|c|}
\hline Environmental Impact & Activities Involved & Welfare Effect \\
\hline Air Pollution & $\begin{array}{l}\text { Mining } \\
\text { UF } 6 \text { production } \\
\text { Enrichment } \\
\text { Fuel fabrication } \\
\text { Transportation } \\
\text { Power generation } \\
\text { Reprocessing }\end{array}$ & $\begin{array}{l}\text { Fluorine and sulfurlc acid emissions could damage live- } \\
\text { stock, grazing land, and crops. Other air pollutants } \\
\text { are emitted from coal plants, which may be used to } \\
\text { supply process power. }\end{array}$ \\
\hline Thermal Discharges & $\begin{array}{l}\text { Enrichnent } \\
\text { Power generation }\end{array}$ & 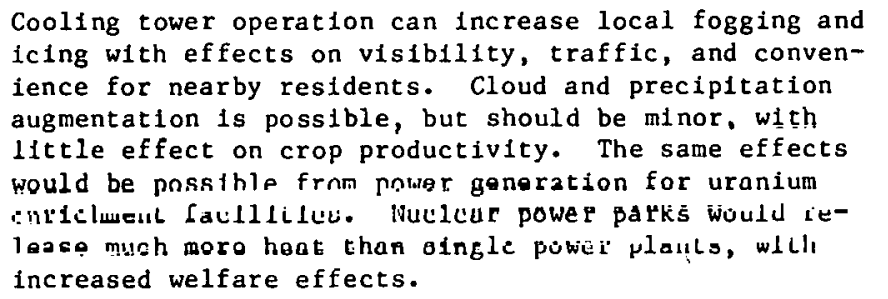 \\
\hline Water Pollution & $\begin{array}{l}\text { llining } \\
\text { liiling } \\
\text { UF } 6 \text { production } \\
\text { Enrichnent } \\
\text { Fuel fabrication }\end{array}$ & $\begin{array}{l}\text { Leaching of ore piles results in runoff threatening } \\
\text { local fisheries. Process effluents can on occasion de- } \\
\text { grade drinking water supplies; degrade irrigation } \\
\text { water, impalring crop growth; and reduce connercial } \\
\text { and recreational use. }\end{array}$ \\
\hline
\end{tabular}

Water Use Changes

Power generation

Reprocessing

Water Use Changes

Mining

Power generation Enrichment.

\begin{tabular}{|c|c|}
\hline Solid Waste & $\begin{array}{l}\text { Mining } \\
\text { lilliliy } \\
\text { IF/ produotion } \\
\text { Fuel fabrication }\end{array}$ \\
\hline Land Use Disturbance & $\begin{array}{l}\text { Mining } \\
\text { Enricluitut } \\
\text { Reprocessing } \\
\text { Decomissioning }\end{array}$ \\
\hline $\begin{array}{l}\text { Elect romagnetic } \\
\text { Dișturbances }\end{array}$ & Transmission \\
\hline Iuulzing Radiation & $\begin{array}{l}\text { litining } \\
\text { lilling } \\
\text { Conversion } \\
\text { Enrichment } \\
\text { Fuel fabrication } \\
\text { Power generation } \\
\text { Reproseceing }\end{array}$ \\
\hline Nolse & $\begin{array}{l}\text { Mining } \\
\text { Power generation } \\
\text { Transmission }\end{array}$ \\
\hline $\begin{array}{l}\text { Aesthetic } \\
\text { Disturbances }\end{array}$ & $\begin{array}{l}\text { Mining } \\
\text { Power generation } \\
\text { Transmission }\end{array}$ \\
\hline
\end{tabular}

llining operations can disrupt water flow. Cooling needs during power production require extensive amounts of water if cvaporative systens are used; uranlum enrichment also has significant water requirements. All three impacts can conflict with downstream uses.

Release of trace elements into terrestrial ecosysteins nál locally reduce crop productivity. Lateral and upward uvveutill uf lerillines may concaminaté rooting zones of otherwise productive cropland.

Agricultural use of rcclatmcd minca may be less productive. Exclustion zones around enrichment and reprocessing plants remove land from other uses, whereas burlal of nuclear wastes may remove all further use of land involvcd.

High intensity nagnetic fields around transmission lines san cause radio and TV interference in fringe-releptiuu arcuas.

Low-level radiation emissions could act as an extremely low-level mutating agent for crops and livestock. Knowledge of a threshuld level for adverse effects from ionfing radiation is uncertain.

No major effects. High-voltage transuission lines create a barely-audible hum.

Aesthetic degradation due to mines, cooling tower plumes, transmission rorridars.

ala1n sources include Refs. 84, 88, 92-97. 
Table 4.17. Welfare Effects of Satellite Power System

\begin{tabular}{|c|c|c|}
\hline Env1 ronmental Impact & Activitles Involved & Welfare Effects \\
\hline Air Pollution & $\begin{array}{l}\text { Launch and recovery } \\
\text { Mining } \\
\text { lanufacturing } \\
\text { Construction } \\
\text { Transportation }\end{array}$ & $\begin{array}{l}\text { Solar cell manufacturing and rocket launches may pro- } \\
\text { duce toxic emissions -- exact emisalons and welfare } \\
\text { effects are unknown. Environmental problems from } \\
\text { fugitive dust from mining and construction and spills } \\
\text { of rocket propellants could occur -- welfare effects } \\
\text { are not expected to be as severe as those of toxic } \\
\text { emissions. }\end{array}$ \\
\hline Atmospheric Changes & $\begin{array}{l}\text { Launch and recovery } \\
\text { Rectenna }\end{array}$ & $\begin{array}{l}\text { Rocket emissions of } \mathrm{CO}_{2} \text { and } \mathrm{H}_{2} \mathrm{O} \text { would augaent the } \\
\text { greenhouse warming effect to a small extent, with } \\
\text { slight effects on precipitation, agriculture, and } \\
\text { ocean levels. }\end{array}$ \\
\hline Thermal D1scharges & $\begin{array}{l}\text { Launch and recovery } \\
\text { Rectenna }\end{array}$ & $\begin{array}{l}\text { Waste heat from the rectenna would raise local tem- } \\
\text { peratures slightly, possibly produce slight changes } \\
\text { ln local cloudiness, and contribute to heat island } \\
\text { effects. lleat from launch ground cloud could modify } \\
\text { local weather. Welfare impacts would likely be minor. }\end{array}$ \\
\hline Water Pollution & $\begin{array}{l}\text { Mining } \\
\text { lanufacturing } \\
\text { Launch and recovery }\end{array}$ & $\begin{array}{l}\text { Water pollutants generated by conventional mining } \\
\text { and manufacturing activitles could degrade drinking } \\
\text { water supplies and cause reduced commerclal and re- } \\
\text { creational yield in affected waters. (Transportation } \\
\text { of propellants could result ln accidental spills, with } \\
\text { slailiar welfare effects.) }\end{array}$ \\
\hline Water Use & $\begin{array}{l}\text { Hining } \\
\text { Hanufacturing } \\
\text { Construction } \\
\text { Launch and recovery }\end{array}$ & $\begin{array}{l}\text { llining of materials could disrupt aquifers and } \\
\text { bodies of water; lapacts unknown. Local water short- } \\
\text { ages due to cooling needs of the launch tower would be } \\
\text { possible, but should be avoldable. }\end{array}$ \\
\hline Solid Waste & $\begin{array}{l}\text { llining } \\
\text { llanufacturing } \\
\text { Launch and recovery }\end{array}$ & $\begin{array}{l}\text { Mine tallings, residuals from photovoltaic cell manu- } \\
\text { facturing, and wastes fron launch-related activities } \\
\text { could increase demand for disposal sites. Toxic manu- } \\
\text { facturing wastes could reduce productivity, and useful- } \\
\text { ness of land to some degree. }\end{array}$ \\
\hline Land Use Disturbance & $\begin{array}{l}\text { lining } \\
\text { Launch and recovery } \\
\text { Rectenna } \\
\text { Transmission }\end{array}$ & $\begin{array}{l}\text { Mining operations, launch and recovery sites, and } \\
\text { rectenna sites remove large parcels of land from al- } \\
\text { ternate uses. Post-mining agricultural use of re- } \\
\text { claimed areas may be less productive. Large rectenna } \\
\text { and launch complex sites could require relocation of } \\
\text { homes, roads, and right-of-ways and Inconvenience } \\
\text { persons having to drive around an area that they } \\
\text { formerly could drive through. }\end{array}$ \\
\hline $\begin{array}{l}\text { Electromagnetic } \\
\text { Disturbance }\end{array}$ & $\begin{array}{l}\text { Launch and recovery } \\
\text { Satellite } \\
\text { Microwave power } \\
\text { transmission } \\
\text { Transmission }\end{array}$ & $\begin{array}{l}\text { Launch vehicle emissions could modify the electron } \\
\text { density of the ionosphere and disrupt communications } \\
\text { systems. Reflected light, and waste heat from the } \\
\text { satellite could create EM disturbances; affected } \\
\text { systems could include radio astronomy. SPS mlcrowave } \\
\text { coupling with electronic systems up to } 100 \mathrm{~km} \text { from } \\
\text { the rectenna could occur. Power transmission can } \\
\text { ef fect fringe TV and radio reception. }\end{array}$ \\
\hline llicrowave Radiation & Rectenna & $\begin{array}{l}\text { Rectenna operation would enit low levels, of luicrowave } \\
\text { radiation beyond exclusion area. The effects of these } \\
\text { emissions are unknown, but possibly could include in- } \\
\text { direct impacts on beneficial Insects and inverte- } \\
\text { brates. IIfrowave radiation could also make crops } \\
\text { more susceptible to other environmental stresses. }\end{array}$ \\
\hline No1se & $\begin{array}{l}\text { Launch and recovery } \\
\text { Transindssion }\end{array}$ & $\begin{array}{l}\text { Nolse from HLLV launches could exceed recommended EPA } \\
\text { nolse'standards. Sonic booms would occur during } \\
\text { launch and reentry. High voltage transisission ines } \\
\text { produce a barely-audible hum. High noise levels near } \\
\text { residentlal areas could reduce property values, cause } \\
\text { annoyance, and interfere with other activities. }\end{array}$ \\
\hline $\begin{array}{l}\text { Aesthet } 1 c^{\circ} \\
\text { Disturbances }\end{array}$ & $\begin{array}{l}\text { Mining } \\
\text { Satelifte } \\
\text { Transuls8ion }\end{array}$ & $\begin{array}{l}\text { Hining activities and cransmission lines would have } \\
\text { visual impacts. The satellites would be visible as } \\
\text { bright objects in the night sky, affecting optical } \\
\text { astronomy. }\end{array}$ \\
\hline
\end{tabular}

AMain sources inciude Kets. $2,54,84,98-10 \dot{10}$ 
Table 4.18 indicates the key areas of impact that have been identified. In the following sections, the principal areas of concern and the rationales for their selection are summarized.

\subsubsection{Air Pollution Generation}

Air pollution emissions of trace and toxic elements could be the major area of concern for both coal and SPS activities. Such emissions will arise in differing amounts from specific activities within each technology. Insufficient data exist for characterizing the type and quantity of trace emissions resulting from the solar cell manufacturing process and rocket launch activities. However, the potential exiete for atmospheric emissiuns uf gallium, arsenic, hydrogen sulfide, and other compounds during GaAlAs manufacture. 54

Emissions of potentially hazardous trace metals are discharged into the atmosphere with the waste gases from combustion at coal-fired generating plants. Although the quantities of emissions are small, their degree of enrichment in the flyash and their hazardous nature requires that this be considered an area for concern. Other coal-related emissions require attention: primary coal combustion emissions of $\mathrm{SO}_{2}$ and $\mathrm{NO}_{\mathbf{x}}$ are precursors of secondary sulfate and nitrate particles, which have been implicated in acid precipitation and visibility impairment. Lakes with reduced buffering capacity can acidify and deteriorate the aquatic environment, resulting in commercial and recreational losses. Degraded visibility may impair navigation and result in cancelled or delayed airline flights.

Emissione euch ao regulated criteria pullulants from coal combustion $\left(\mathrm{SO}_{2}, \mathrm{NO}_{\mathrm{x}}\right.$, TSP, $\left.\mathrm{HC}, \mathrm{CO}\right)$, cooling tower drift releases from coal and nuclear generating stations, and fluoride from nuclear fuel conversion facilities are areas of moderate concern and are likely to be controlled to acceptable levels. However, these pollutants have been implicated in the physical damage to and reduced useful life of metals, building materials, and stone objects such as sculptures. Pollutants at elevated levels have affected the productivity, appearance, and yield of crops, causing economic damage.

\subsubsection{Climatic Changes Due to Air Pollution Emissions}

The impact on global climate that is currently given the most attention is the global warming effect caused hy tncreasing $\mathrm{CO}_{2}$ levele in the ntmnaphere and the resulting "greenhouse effect." Atmospheric models predict that doubling of $\mathrm{CO}_{2}$ levels above pre-industrial levels will produce a global average warming of $1^{\circ}$ to $3^{\circ} \mathrm{C} .102$ This could occur as early as 2025 , although noticeable warming should not be detected before 2000. Such a temperature increase may significantly affect precipitation patterns, agricultural production, energy use, and ocean levels through melting of polar ice.

Coal combustion releases substantial amounts of $\mathrm{CO}_{2}$ into the atmosphere ( $5 \times 10^{6}$ metric tons annually for a 1,000 MWe power plant). Although this is not a local problem, coal combustion contributes significantly to the total man-made input of $\mathrm{CO}_{2}$ into the atmosphere. It has been estimated that 
Table 4.18. Potential Severitya of and Status of Knowledge ${ }^{b}$ about Key. Environmental Welfare Issues $c$

\begin{tabular}{|c|c|c|c|c|c|c|c|}
\hline \multirow{2}{*}{$\begin{array}{c}\text { Envi ronmental Inpacts } \\
\text { with. Possible } \\
\text { Welfare Effects }\end{array}$} & \multicolumn{2}{|c|}{ Coal } & \multicolumn{2}{|c|}{ Nuclear } & \multicolumn{2}{|c|}{ SPS } & \multirow{2}{*}{$\begin{array}{l}\text { Activities Causing } \\
\text { Potentially Severe } \\
\text { Welfare Cffects }\end{array}$} \\
\hline & $\begin{array}{l}\text { Potential } \\
\text { Severity }\end{array}$ & $\begin{array}{l}\text { State of } \\
\text { Knowledge }\end{array}$ & $\begin{array}{l}\text { Potential } \\
\text { Severity }\end{array}$ & $\begin{array}{l}\text { State of } \\
\text { l'nowledge }\end{array}$ & $\begin{array}{l}\text { Potential } \\
\text { Severity }\end{array}$ & $\begin{array}{l}\text { State of } \\
\text { Knowledge }\end{array}$ & \\
\hline Air Pollution & 1 & $B-C$ & $2-3$ & B & 1 & $\mathrm{C}$ & $\begin{array}{l}\text { Coal-fired power generation } \\
\text { (toxic and secondary } \\
\text { pollutants). } \\
\text { SPS materials manufacture } \\
\text { and rocket launch. }\end{array}$ \\
\hline Atmos pheric Changes & 1 & $\mathrm{~B}-\mathrm{C}$ & 4 & B & 3 & B & $\begin{array}{l}\text { Coal-fired power generation } \\
\left(\mathrm{CO}_{2} \text { emissions }\right)\end{array}$ \\
\hline Thermal Discharges & 2 & B & 2 & B & 2 & B & -- \\
\hline Water Pollution & 1 & B & 1 & B & 1 & $\mathrm{C}$ & $\begin{array}{l}\text { Coal mining (underground). } \\
\text { luclear fuel fabrication. } \\
\text { SPS materials manufacture. }\end{array}$ \\
\hline Water Use & 2 & B & 2 & B & 3 & c & -- \\
\hline Solid Waste & $2-3$ & A & 3 & B & $2-3$ & c & -- \\
\hline Land-Use Disturbances & $1-2$ & A & 1 & B & $\cdot 1$ & $B-C$ & $\begin{array}{l}\text { Coal mining (surface). } \\
\text { liuclear waste disposal. } \\
\text { SPS raterials mining, rocket } \\
\text { launch, rectenna sites. }\end{array}$ \\
\hline $\begin{array}{l}\text { Elect romagnet ic } \\
\text { Disturbances }\end{array}$ & 3 & B & 3 & B & 1 & $B-C$ & SPS rectenna operation. \\
\hline Microwave Radiation & 4 & B & 4 & B & 1 & c & SPS power transmission. \\
\hline Ionizing Radiation & 3 & B & 3 & B & 4 & B & -- \\
\hline Holse & 3 & $A$ & 3 & $\Lambda$ & 1 & A & SPS rocket launch. \\
\hline Aesthetic Disturbances & 2 & A & 2 & A & 2 & B & -- \\
\hline
\end{tabular}

aseverity ranking is based on the most serious welfare effects of the activities within each fuel cycle. Potential severity is ranked according to the following criteria:

1 - Very significant contribution to welfare effects. 3 - llinor but measurable contribution to welfare effects.

2 - Significant ccntribution to welfare effects. 4 - Negligible contribution to welfare effects.

bstate-of-knowledge ranking:

- A - Issue thoroughly documented and understood.

B - Parts of issue understood, but gaps in knowledge exist.

C - Very lit le knowledge of issue exists.

'Source: Ref. 34 . 
coal-fired generating plants in the United States alone produce as wuch as $20 \%$ of the world-wide, man-made emissions of $\mathrm{CO}_{2} .102$ Furthermore, coal combustion also releases amounts of other "greenhouse" gases such as $\mathrm{SO}_{2}$ and $\mathrm{H}_{2} \mathrm{O}$, which appear to be of a less severe nature.

Another area of concern is the increase in global levels of atmospheric particles. Particles act to change the radiation properties of the earthatmosphere system and effectively warm or cool the earth's surface, depending on the physical location and the optical properties of the particles. It has not been established whether or not the increase in atmospheric particle concentrations over the past century has produced a net warming or cooling effect. The direct emissions of particles from coal combustion, and emissions of gaseous species such as sulfur and nitrogen oxides, which are converted to particles in the atmosphere, do not contribute significantly to global levels of atmospheric particles. 103

The major emissions into the atmosphere froin SPS activities will occur from rucket launches. Rocket efflucnts include substancial amounts of $\mathrm{CO}_{2}$, but these emissions are at least 100 times smaller than the $\mathrm{CO}_{2}$ emissiuns from coal combustion for an equivalent amount of system capacity.102 The possibility exists for some upper lcvel clouds to be formed by $\mathrm{H}_{2} \mathrm{O}$ injections into the mesosphere. The impacts of these clouds do not appear to be significant but are not well known at present. A slight depletion of the total ozone column due to emissions of $\mathrm{H}_{2} \mathrm{O}$ and $\mathrm{NO}_{x}$ is possible but is not expected to affect global climate to a noticeable extent. 54

The ability to reliably predict climatic change resulting from air pollution emissions is currently limited by ocveral faclurs. There is considerable uncertainty concerning the extremely conplex nature of the earthatmosphere system and the interrelations between the various parts of the system. Insufficlent knowledge hampers the prediction of how second-order coupled processes or "feedback mechanisms" might enhance or suppress a firstorder effect on climate such as a surface warming due to $\mathrm{CO}_{2}$. There is also uncertainty about the magnitude of the effect of other greenhouse gases and atmospheric particles compared to the $\mathrm{CO}_{2}$ effect.104 The role of natural climatic fluctuations in enhancing or masking trends due to man-made emissions further contributes to the uncertainty of predictions. It is expected that the ab1lity to predict climatic change will improve with additional research; however, drastic improvements in forecast roliability are probably not to be expected in the near future because of the complexity of the problem.

\subsubsection{Therwal Discharges and Resulting Climatic Change}

Production of electrical energy results in the rejection of waste heat to the environment. A nuclear power plant with an efficiency of $32 \%$ releases two units of waste heat for each unit of heat used to produce electrical energy. The impacts of this waste heat are local and dependent on the type of cooling technology, the amount of heat released, and the local ambient meteorological conditions. Most existing and planned nuclear power plants employ cooling towers. 54 Mechanical draft cooling towers can produce an increase in local ground fog a few days per year within a few thousand feet of the towers. Some local icing may occur during the winter when the moist 
thermal plume contacts the ground. Production or enhancement of cloudiness in the vicinity of large cooling towers has also been observed.105 In areas where these problems occur, technology is available at a moderate incremental cost to eliminate the adverse effects.

A relatively unlikely, but potentially significant impact could occur in the future if nuclear power plants are clustered into energy "parks". The large release rate of waste heat (e.g., 72,000 MW) over an area of relatively small radius ( 10 to $100 \mathrm{~km}$ ) could produce or enhance severe local weather events such as thunderstorms and hail.106

A coal-fired power plant is generally more efficient than a nuclear power plant ( $38 \%$ versus $32 \%$ ). Thus, the local waste heat impacts for coal technologies should be smaller than those of nuclear technologies for a plant of equal size and similar cooling technology. In addition, the waste heat effects from coal-fired power plants are reduced because not all of the waste heat is emitted from the cooling tower. About $25 \%$ of the total waste heat of a coal-fired plant is emitted from the stack.

The SPS rectenna will release waste heat of a density of $7.5 \mathrm{~W} / \mathrm{m}^{2}$ over a $100 \mathrm{~km}^{2}$ area. This is an energy density of about $10 \%$ of the average net solar radiation at the earth's surface. In conditions of light winds, temperature perturbations of as much as $1^{\circ} \mathrm{C}$ could occur in the vicinity of the rectenna. 107 Changes in cloudiness near the rectenna could occur, but an impact on precipitation-distribution seems unlikely.

\subsubsection{Water Pollution}

Insufficient information concerning the SPS solar cell manufacturing process precludes an accurate assessment of the severity of water-polluting emissions from this activity. However, the toxicity of the raw materials and the possibility of accumulation in the environment warrants further attention. With data currently available, it is not possible to identify specific water pollution problems or effects that could occur during normal operation. However, it is possihle that water pollution may result from SPS launches and rectenna construction runoff.

Acid mine drainage from underground coal mining activity is an impact of concern and in the past such drainage has degraded many eastern waterways. Acid-contaminated waters endanger aquatic populations by altering species type, diversity, and quantity, thereby limiting commercial and recreational opportunities. Various federal and state programs have instituted water quality criteria, effluent limitations, and reclamation requirements to control the problems associated with mining activity. There is controversy over the ability of these laws to achieve the desired effect.

Nuclear fuel fabrication is also an area of concern although a minor one. Existing plants have occasionally discharged ammonia, nitrates, and fluorides into low-flow streams, thereby reducing the quality of the water. 


\subsubsection{Water Use Changes}

Heavy consumption of water is treated in Sec. 4.4 as a resource issue, although heavy use of water can decrease the amount of water available downstream for dilution and is therefore a welfare issue as well. Mining operations can disrupt aquifers resulting in lowering of the ground water table and alteration of water flow patterns that could affect crop irrigation. Wet cooling towers at coal or nuclear power stations can consume large quantities of water. Technologies that do not consume water could be utilized in areas where water is scarce. During the nuclear fuel cycle, the production of uranium hexafluoride and enriched uranium (gaseous diffusion process) also requires heavy consumption of water.

\subsubsection{Solid Waste Generation}

The impact of solid waste generation cannot be entirely separated from land use issues. However, small amounts of waste can have large impacts on future land use when the nature of the waste affects the disposition of the land. into which it is placed. Issues concerned with the quantity of land necessary for the placement of solid waste are treated in Sec. 4.4 as a land-resource issue.

Manufacture of the gallium aluminum arsenide solar cell will produce $2 \times 10^{7}$ metric tons of aluminum oxide waste for each $5 \mathrm{GW}$ satellite produced. This quantity of waste could present a disposal problem if all cells were manufactured at a single facility. Aluminum oxide does have commercial value for other purposes, which could lessen the impact of its disposal.

A 1,000 MWe coal burning power plant using a non-regenerative scrubher may produce about $3 \times 10^{7}$ metric tons of ash and lime/limestone waste annual1y. The actual amount of waste will vary by fuel quality and type of particulate and $\mathrm{SO}_{2}$ control technology. The quantity of waste leaving the power plant site will vary depending on the avallability of land for on-site disposal. Procedures for returning these areas to productive use are available but are not mandated. Regulations governing the toxic nature of these wastes are currently being considered.

Modest amounts of solid and liquid waste are generated in support of the nuclear power cycle. However, most of these activities generate radioactive waste that must either be sent off-site for commercial burial or buried on site. Among these wastes are;

- 500 metric tons/facility/year of uranium hexafluoride process effluents consisting of iron, calcium, magnesium, copper, and nonvolatile fluorides (shipped off-site).

- 90 metric tons/facility/year of enrichment cleanup sludge consisting of mostly settleable solids, precipitated metals and soll runoff (retained on-site).

- 700 metric tons/facility/year of calcium fluoride from fuel fabrication activities (generally retained on-site). 
- Numerous liquid and solid radwastes that are activated through fission product leakage, activation of chemical inhibitors, reactor purification procedures and spent reactor parts (shipped off-site).

- Spent reactor fuel shipped to the reprocessing center.

Large amounts of mine and mill tailings should not present any specific problem since they are often used as backfill and retained on-site. However, inadequate precautionary measures have, on occasion, permitted low-level radioactive tailings to enter the environment.

Coal, nuclear, and SPS technologies each require the extraction of conventional materials, such as steel and aluminum. Additionally, coal and nuclear power require mining of fuels. These activities will not produce any unique problems with respect to solid waste generation.

\subsubsection{Land Use Changes}

The quantity of land removed from public use and the permanent isolation of land are not considered here since these are principally resource issues. Additional questions concerning changes in land use remain. Mining operations for fuel and materials have the potential of contaminating or eroding other land areas. Reclamation of mined areas may not be entirely effective in returning the land to its formerly productive state. Reclamation of mined areas in arid climates such as the southwestern U.S. is difficult. Proper operation and reclamation techniques should reduce the level of concern.

Electromagnetic interference with communication systems near the SPS rectenna location has the potential for limiting the type and diversity of land use activities around the site; although it is conceptually possible to mitigate these effects, specific measures and cost estimates are currently unavailable. The use and removal of large land areas from public use for the rectenna will inconvenience persons having to drive around the. site and will affect navigable waterways in a similar way.

\subsubsection{Noise Generation}

The major noise disturbances (60-80 dBa, 24-hr weighted average) will be from SPS rocket launch operations, 54 and will likely exceed recommended EPA 24-hr time-averaged noise standards and elevate noise levels in surrounding communities to a distance of $30 \mathrm{~km}$. Launches are projected to occur several times a day. Sonic booms during launch and reentry operation will elevate noise levels to a lesser degree. Elevated noise levels near residential areas could lead to depressed property values. These effects could be mitigated by performing launch operations for from populated areas.

Coal and nuclear mining and power generation have a moderate noise impact. Noise from power production artses from cooling tower fans and plant support activitles. Blasting and drilling during mining may also elevate noise levels in the immediate vicinity. Nolse measurements assessed at the 
property line in most cases are not expected to be significant, and use of a buffer zone between the noise source and the property line frequently serves as a mitigation technique.

Another source of noise that is common to the energy technologies will occur during rail transport of fuels and materials. Transmission line noise is only barely audible with $345 \mathrm{kV}$ AC lines but increases with the use of larger lines.

\subsubsection{Electromagnetic Disturbances}

Significant electromagnetic disturbances may occur from ErS-micsuwave coupling with electronic systems at distances of up to $100 \mathrm{~km}$ from the rectenna site. 54 Functional degradatinn can affecl milicary 1adur, law entorcement, emergency and litility. data transwissiuls, and other susceptible systems. However, it is anticipated that modifications (currently undefined both technically and from a cost point of vicw) could be made to these systems to mitigate these effects.

Other electromagnetic disturbances relatcd to SPS activities may be anticipated. Rocket effluents may induce ionospheric alterations that may affect communication systems relying on the ionosphere. Debris iluuds consisting of orbiting gaseous and particulate effluents could interfere with radioastronomy and radionavigation. The likelihood and severity of these occurrences is unknown but is currently under investigation in the environmental assessment of the SPS. 54

High intensity electromagnetic fielde gencrated durlug power transmission have, in some instances, caused radio and $T V$ disturbances in fringe reception areas. This effect is thought to be of minor concern. Huwever, it i.s common to all centrallzed energy technologies and is likely to increase with the higher transmission-line voltages.

\subsection{1? Radioactive Emissions}

Radiation releases containing trace radioactive materials result from the burning of fossil fuels 91 and all othcr activities in the nuclear fuel cycle.92,93 SPS activities do not result in ionizing radiation emissions.

The ofudy ot airburne radioactive particles from coal combustion has not been comprehensive. Radioactive effluents originate in coal and are emitted with the stack gases. Uranium, thorium, and radon constitute the radioactive emissions of coal combustion and may release on the order of 1.2 $\mathrm{Ci}$ annually, depending on the nuclide concentration in the coal seam. Radioactive airborne releases from a 1,000 MWe coal plant are considerably below the amount resulting from a boiling water reactor. Standards limiting radioactive emissions from fossil fueled power plants do not currently exist but could be promulgated under the Federal Clean Air Act Amendments of 1977.

Low-level radiation emissions from routine operation of nuclear power facilities are greatest during power generation, fuel-reprocessing, and 
milling activities. The use of exclusion zones around nuclear facilities reduces the off-site exposure. Radiation emissions are below the levels established by federal Nuclear Regulatory Commission regulations (10 CFR* 20, 10 CFR 50), and are characterized as having low welfare impact. However, the radiation threshold level beneath which an effect will not be observed is uncertain and therefore these standards are being reexamined.

\subsubsection{Microwave Radiation}

Microwave radiation levels will be elevated in the vicinity of the SPS rectenna station. Levels within the exclusion zone will be as high as $23 \mathrm{~mW} / \mathrm{cm}^{2}$. Levels below $0.1 \mathrm{~mW} / \mathrm{cm}^{2}$ will be experienced beyond the exclusion zone. 2

Limited information exists regarding the direct impact of microwave radiation on biological systems. All of the information that is available relates to high-level microwave exposures. 54 Although the likelihood of occurrence of microwave effects is unknown, the potential severity could be significant. Microwave exposure may alter the mortality, reproduction, and behavior of birds, invertebrates, and beneficial insects. Disturbances of the bee pollinization process could affect food supplies and is currently under study. Direct microwave exposure could increase the susceptibility of crops to environmental stress such as drought, resulting in decreased yields. Birds relying on the earth's magnetic field for navigation may show altered migration patterns. Judicious siting may reduce the extent of impact from microwave exposure.

\subsubsection{Aesthetic Disturbances}

Direct aesthetic impacts are site specific, and the extent of these disturbances can be moderated by considering archaeological, cultural, historjcal, protected scenic, and recreational areas, and rare and endangered species during the siting process. Other types of aesthetic degradation may arise from unsightly mines; visually disturbed areas, e.g., facilities sited in rural areas; transmission corridors; visible cooling tower plumes and plume shadows; and noise producing operations.

The aesthetic impacts of satellite operation include the brightness of the satellites visible in the night sky. The diffuse glare from reradiated light may also interfere with optical astronomy.

\subsection{RESOURCES}

The discussion in this section concerns the preliminary assessments of five resource areas -- land, materials, energy, water, and labor -- for five energy technologies -- coal-gasification/combined-cycle (CG/CC), light water reactors (LWR), liquid metal fast breeder reactors (LMFBR), terrestrial photovoltaics (TPV), and satellite power systems (SPS). Table 4.19 qualitatively summarizes the resulte presented in the following seetions.

*Code of Federal Regulations 
Table 4.19. Simmary of Prelimizary Comparative Assessments -- Resources

\begin{tabular}{|c|c|c|c|c|c|}
\hline Resource & LWR & $\mathrm{CG} / \mathrm{CC}$ & LMFBR & TPV & SPS \\
\hline \multirow[t]{2}{*}{ Land } & $\begin{array}{l}\text { Small plart } \\
\text { æequiremeris. }\end{array}$ & $\begin{array}{l}\text { Small plant } \\
\text { requirements. }\end{array}$ & $\begin{array}{l}\text { Smaller impacts } \\
\text { than LWR. }\end{array}$ & $\begin{array}{l}\text { Large land areas } \\
\text { required for solar } \\
\text { collectors. }\end{array}$ & $\begin{array}{l}\text { Large, contiguous } \\
\text { rectenna sites. }\end{array}$ \\
\hline & $\begin{array}{l}\text { Some mining } \\
\text { impacts. }\end{array}$ & $\begin{array}{l}\text { Mining impacts } \\
\text { are the main } \\
\text { problem. }\end{array}$ & & $\begin{array}{l}\text { Possibly lorg-haul } \\
\text { transmissior. }\end{array}$ & $\begin{array}{l}\text { Possibly long-haul } \\
\text { transmission. }\end{array}$ \\
\hline Materials & $\begin{array}{l}\text { Uranium sup- } \\
\text { p1y is limited. }\end{array}$ & $\begin{array}{l}\text { Good supply } \\
\text { of coal. }\end{array}$ & $\begin{array}{l}\text { More efficient } \\
\text { use of uranium } \\
\text { supply than LWR. }\end{array}$ & $\begin{array}{l}\text { Seven potential } \\
\text { problem materiais } \\
\text { identified. }\end{array}$ & $\begin{array}{l}\text { Three problem } \\
\text { materials iden- } \\
\text { tified (mercury, } \\
\text { tungsten, gallium). }\end{array}$ \\
\hline Energy & $\begin{array}{l}\text { Payback about } \\
\text { one year. }\end{array}$ & $\begin{array}{l}\text { Payback about } \\
\text { one year. }\end{array}$ & $\begin{array}{l}\text { Payback about } \\
\text { one year }\end{array}$ & $\begin{array}{l}\text { Payback for } \mathrm{Si} \\
\text { system about } 19 \\
\text { years.a }\end{array}$ & $\begin{array}{l}\text { Payback for } S i \\
\text { about six years; } \\
\text { Ga about one year. }\end{array}$ \\
\hline . & & & & $\begin{array}{l}\text { High energy in- } \\
\text { tensity of cell } \\
\text { production. }\end{array}$ & $\begin{array}{l}\text { Less sensitive to } \\
\text { energy intensiry } \\
\text { of cells. }\end{array}$ \\
\hline Water & $\begin{array}{l}\text { Small cooling } \\
\text { losses. }\end{array}$ & $\begin{array}{l}\text { Contanination } \\
\text { due to coal } \\
\text { mining. } \\
\text { Small cooling } \\
\text { losses. }\end{array}$ & $\begin{array}{l}\text { Small cooling } \\
\text { lcsses. }\end{array}$ & $\begin{array}{l}\text { No impact. } \\
\text { Negligible } \\
\text { water use. }\end{array}$ & $\begin{array}{l}\text { No impact. } \\
\text { Negligible } \\
\text { water use. }\end{array}$ \\
\hline $\begin{array}{l}\text { Labor } \\
\text { Require- } \\
\quad \text { ments }\end{array}$ & $\begin{array}{l}\text { Small but } \\
\text { highly-skilled } \\
\text { operations and } \\
\text { naintenance } \\
\text { force. }\end{array}$ & $\begin{array}{l}\text { Skills avail- } \\
\text { able today. }\end{array}$ & $\begin{array}{l}\text { Small but } \\
\text { highly-skilled } \\
\text { oferations and } \\
\text { maintenance } \\
\text { fcrc?. }\end{array}$ & $\begin{array}{l}\text { Skills readily } \\
\text { available. }\end{array}$ & $\begin{array}{l}\text { Space construction } \\
\text { requires new and } \\
\text { highly-skilled } \\
\text { work force. }\end{array}$ \\
\hline
\end{tabular}

a Improved celi efficiency and for production ejergy rəquirements would reduce payback'significantly. 


\subsubsection{Land}

The objective of the land use analysis 108 is to characterize the nature, purposes, and effects of land use by the SPS and alternative energy technologies. The criteria used to characterize land use include:

- Area of use

- Time -- the period of time that use of land is dedicated to a specific energy technology

- Location

- Lost. opportunity -- the quality of the land used and its potential for or actual use for other purposes

System boundaries are defined to encompass extraction and processing of fuel, plant requirements (including the construction period), transmission corridors, and waste disposal. Excluded from the analysis are secondary uses of land, e.g., for factories that manufacture system components.

The method of analyzing land use is a side-by-side listing of land requirements, by category, for each energy supply system. For the most part, this preliminary look at land requirements was limited to results published in the open literature. Data sources include environmental impact statements, 15,109 system designs,2,110 system descriptions, $111-113$ and other comparative studies. $8,78,114,115$ In order to focus the comparison, the areas for each system are normalized on the basis of a megawatt-year (MW-yr) of energy. To perform this normalization, it was often necessary to make assumptions (e.g., load factor, plant life) about individual technologies. The results are listed in Table 4.20. Categories in the tables are: construction (the plant, areas surrounding the plant, and transmission corridors that are disrupted during construction; for SPS, the rocket launch area is a special issue), the plant itself (including a buffer zone and area for storage of fuel, if required), and fuel (including mining operations), disposal, and transmission. A number of data deficiencies exist because of incomplete system characterizations and differences in the way data are reported. To be more specific, additional characterization is required for the construction phase for most technologies, waste disposal for coal-gasification/combinedcycle and LMFBR, and transmission for all systems (but particularly TPV and the SPS).

Transmission for TPV and the SPS potentially presents more difficult problems because these systems are likely to be sited, on the average, further frum load centers than cnal and nuclear plants. TPV sites are most likely to be in the Southwest, and SPS rectenna sites are most likely to be in the South. Long transmission lines would be needed to deliver energy to the Northeast. (Sources for the long transmission distances for LWR (1.e., 1600 $\mathrm{km})$ are probably overestimating the need to remotely locate a nuclear plant, unless nuclear power parks come into existence. Also, mine-mouth generation of electricity by coal, the "coal by wire" concept, would result in very long transmission lengths for coal technologies as well.)

The different ways of normalizing land data limiled the usefulness of some of the data. The surveyed literature presented land requirements in 
Table 4.20. Summary of Land Requirements

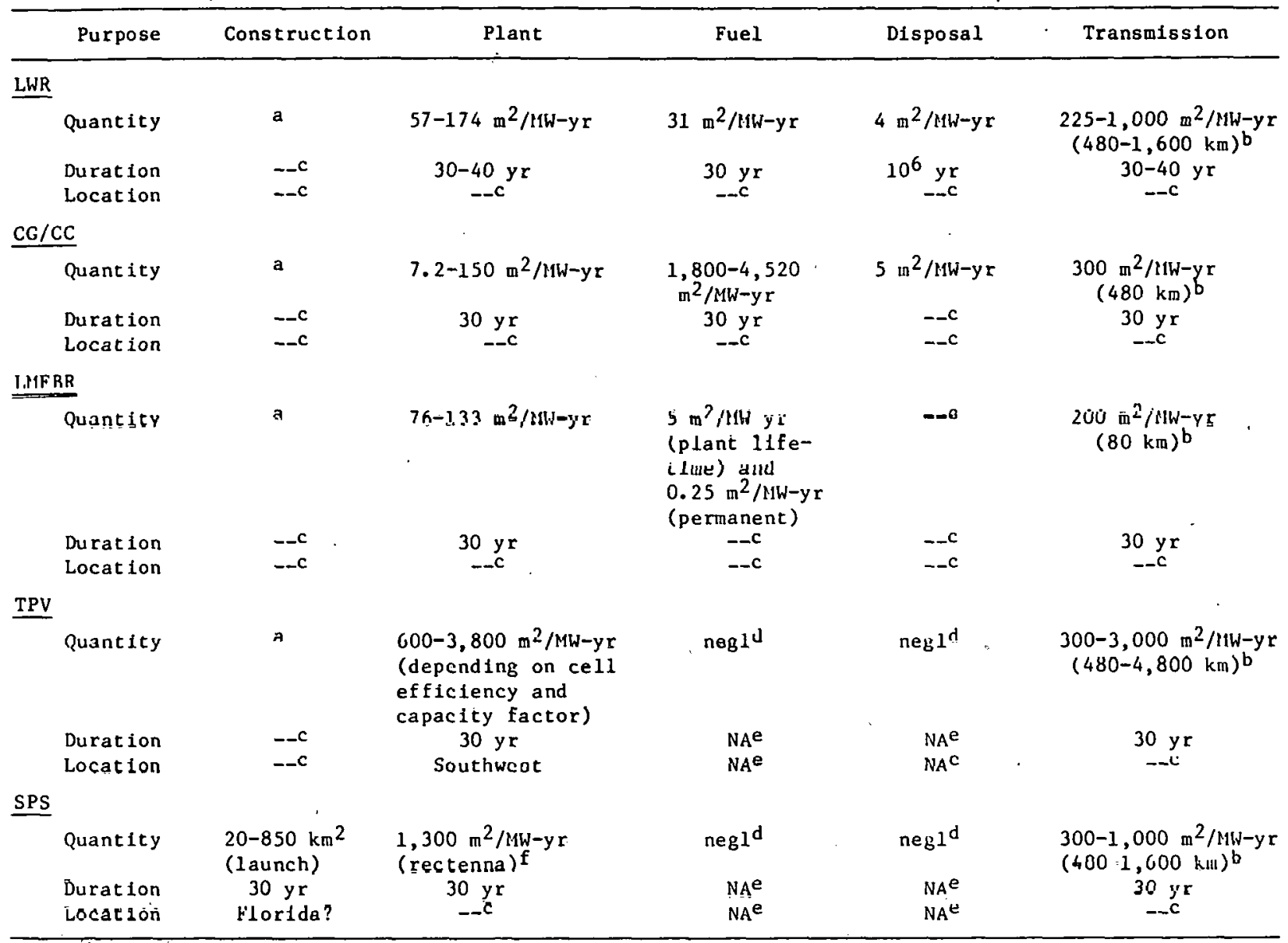

appruximately the sum of plant and transmissinn requitremente.

bistance to load center; see discussion in text.

c- Data lacking.

$d_{\text {nćgl - negligible. }}$

$e_{\text {NA }}$ - Not applicable.

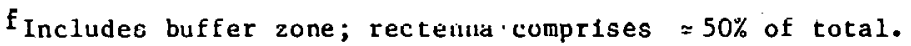

various unlls, fur example, acres/MW, acres/MW-yr, and acres/yr/1012 Btu. Coneictcnt unita could bu calculatcd from the publislied data if such numbers as plant lifetime, capaçity factor, and fuel heat rates were known. However, there was often no explicit statement of these values; thus, it was not possible to arrive at the basic numbers that were used, or to compute different units of measure. The data listed in Table 4.21 generally indicate that coal and nuclear technologies require much less land per unit of energy than do solar technologies.

A wide range of uncertainty is shown for the plant area for the LWR and TPV. For nuclear plants, the uncertainty stems mainly from diverse opinions concerning the exclusion area required around the plant; the plant proper 
requires very 1 ittie land. For terrestrial solar technology, factors contributing to the uncertainty include cell efficiency and the amount of spacing required between solar blankets. Costs are affected by the amount of land and length of time that land is required. The direct dollar cost of acquiring or leasing the land is rather obviously affected. There are also opportunity costs associated with the denial of alternative uses of the land. Although these costs are often difficult to measure, they constitute an important issue concerning the significance of land use. Another significant factor affecting cost is location. As scenarios are developed and potential sites are identified, 116 first on a regional basis and then for precise locations, more detailed work can proceed on quantifying the land issues.

The preliminary assessment does not include an assessment of type, location, or cumulative land requirements for energy technology. Subsequent land analyses that include future energy deployment scenarios and facility siting will add another dimension to the land assessment. Specific site locations are probably not possible considering the time frame of energy deployment (i.e., post 2000). However, regional siting with hypothetical locations could serve to indicate the type and approximate load consumed for energy development.

\subsubsection{Materials}

The objective of this analysis was to assess potential materials problems by identifying the types and quantities of materials required by SPS and alternative technologies. Defining materials problems is not simple; there are many important factors that must be included: resources, reserves, production capacity, import dependence, price, and opportunity costs.

The possibility of resource and/or reserve constraints depends on market penetration scenarios. Domestic production factors include current capacity, normal growth rate, and required growth rate to meet a given demand level. If domestic supplies of a material are inadequate, the balance must come from foreign markets; consequently, the possibility of cartels and the effects on the U.S. balance of trade must be considered. Since price is influenced by supply and demand, the possible effects of large increases in supply or demand must be investigated. If a material is largely used by a single energy technology, opportunity costs result from the limited use of the resource for other purposes. The possibility of substitute materials becomes an important issue for any materials judged to be a potential problem.

This preliminary comparative assessment is based on available research. In general, conclusions about materials problems published in the open literature were not based on rigorous considerations of the above-mentioned criteria. Thus, there is a lack of uniformity in conclusions from technology to technology because the assessments were done by different researchers. No attempt was made to reconcile these differences for this preliminary assessment. 
Sources include environmental impact statements, 15,109 system designs, 112,117,118 system descriptions, 111,119 federal documents, 120-122 and comparative studies. $8,77,123,124$

Concerning the SPS, potential materials problems have been noted for gallium (limited domestic production capability), mercury (high foreign dependence, but lessening), and tungsten (limited domestic production capability). These problems with mercury or tungsten suggest that there may be significant economic impacts or uncertainty in supply. Problem materials for CG/CC may include chromium, cobalt, manganese, molybdenum, nickel, tungsten, and aluminum, which are subject to the difficulties of short supply and large import requirements (as a fraction of U.S. annual consumption). For the LWR, the main concern is uranium supply. No problems have been identified for the LMFBR. Battelle Pacif1c Northwest Laboratory has identified seven potential materials problems for terrestrial photovoltaic systems: aluminum, gallium, germanium, gold, indium, iron/steel, and lead.124

Much as $1 \mathrm{~s}$ the case for land assessment, deldiled allalysis of materials must include an energy deployment scenario; in addition, deficiencies in technology characterizations, hence in material specification, must be resolved before a materials assessment can proceed beyond the preliminary level.

\subsubsection{Energy}

\section{Objective}

The objective of the net energy analysis 125 was to provide a preliminary comparison of the net energy requirements of the SPS (silicon and GaAlAs solar cells) and alternative energy supply systems (CG/CC, LWR, and TPV with silicon solar cells). Conventlonal energy syslems provide substantially more energy than was required to pur them into operallun alld su llie cuncept of net energy analysis was not important to the decision-making process. Advanced technologies, however, require more energy investment to recover each unit of usable energy and so the net energy assessment becomes a more important decision parameter.

\section{Approach}

This preliminary analysis considers state-of-the-art (circa 1985) capabilities for macerials extraction and fabrlcaliun in order to identify critical areas needing improvement. The possibility of technological improvements was considered in a number of key areas. The energy content of the fuel is not considered.

The boundary of each energy system was defined as extending from the primary resource (coal, uranium, and solar radiation) to electricity transmitted from the generating plant. The boundary includes environmental control systems and procedures to the extent they are directly attributable to the energy system. Materials, fuels, and electricity required for plant construction and operation are also considered. 
A combination of process analysis and input/output analysis was used to compute the energy balance parameters for each supply system. Process analysis involves a detailed balance of energy flows into and out of a system. It is the most accurate and most involved methodology and can be applied to situations where a great deal of process-specific information exists. Input/ output ( $I / O)$ analysis uses an analogy to. economic input/output analysis to determine the energy "costs" of any energy supply. It involves an identification of the interactions between sectors of the economy required to produce energy and a translation of the flow of goods and services among sectors into energy equivalents.

Each of the systems chosen for evaluation is described as a collection of system elements. Each element represents a particular piece of hardware, processing step, energy conversion step, or transportation mode. The energy balance of each system element is described in Fig. 4.21. The primary input is in the form of fuel. (e.g., coal into a coal-processing plant) or energy (e.g., heat from a solar collector into a boiler). The ancillary operating inputs are those energy forms required to keep the process operating. The gross output is the energy or processed fuel that results from the system element. A portion of this gross output may be used to meet internal energy requirements. The balance is the net output that goes on to become the primary input of the next system element. The losses are the difference between the outputs and the inputs.

Up to this point, a straightforward energy balance can be carried out since all quantities of materials and their energy contents can be directly computed. This is the extent of the process analysis used in this assessment.

The indirect energy requirements of the system are embodied in the capital energy inputs, i.e., the materials, fuels, and electricity required to build the system element, and in the energy required to supply the electricity, fuels, and materials for operating inputs. A simplified analysis was used to compute direct energy requirements during this phase of the analysis.

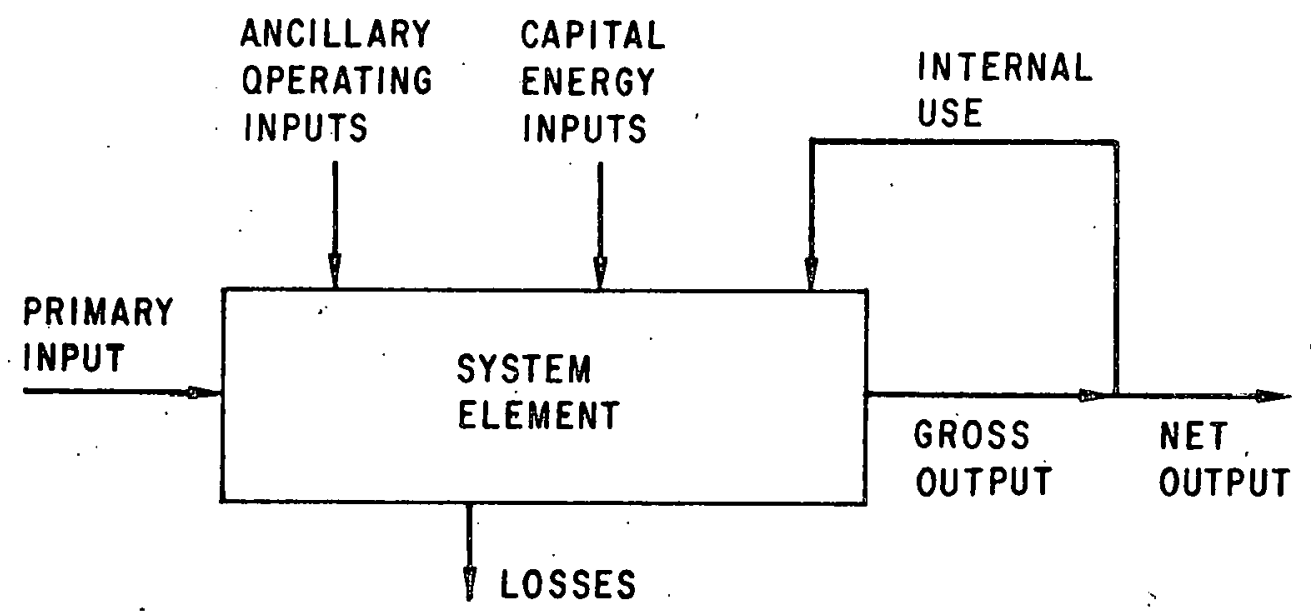

Fig. 4.21. Schematic of Energy Balance 
For each system element the quantities of materials, fuels, and electricity required to build and operate the system are compiled using published data on energy requirements $126-129$ expressed either in joules per ton of materials or joules per dollar cost of material. The physical material quantity or material cost is converted into an energy requirement equivalent.

\section{Energy Balance Parameters}

A number of energy balance parameters were calculated, including gross efficiency, operating efficiency, operating ratio, lifetime efficiency, 1 ifetime ratio, and payback period. Gross efficiency measures the amount of energy delivered per unit of input energy. Operating efficiency is a more complete measure of how effectively the basic energy resource is being utilized, i.e., how efficiently a given technology extracts useful energy from a primary energy form. The operating ratio eliminates the energy content of the primary resource from the calculation. This parameter is a measure of how much useful energy $c$ an be extracted from a primary resource. It cunsiders the primary resource as fundamentally unusable in its basic state and measures the, amount of energy that must be expended to convert it into usable form. The 1 ifetime efficiency and 1 ifetime ratio are analogous to the operating efficiency and operating ratio. They include the capital energy investment in the balance process, which represents the energy required to construct the system. Payback period is the time required for the system to produce enough useful energy to match the energy investment in building and operating it. All of these parameters must be considered because the efficiency and payback calculations tend to be better for the coal and nuclear systems than for the solar systems, whereas the operating ratio and lifetime ratio calculations tend to be better for the solar-based systems than for the coal and nuclear systems.

Annual and lifetime net outputs are computed in terms of electrical unita. All inputo arc computed in thermal units; they do not include the thermal energy content of the fuels or materials involved, but only the energy expended for mining, processing, transportation, etc. These are the usual conventions used in doing a net energy analysis. This approach thus represents a short-term view of the use of a nonrenewable resource base; for example, in computing payback, the interest is in determining at what rate an energy system returns electrical energy, given the investments (inputs) required. It does not consider the issue of depletion of a nonrenewable resource base, which must be addressed as a lost opportunity issue tor alternate uses of the resource. Furthermore, if the thermal content of a nonrenewable resource were considered, the payback period for systems based on nonrenewable resources would be infinite by the second law of thermodynamics.

\section{$\underline{\text { Results }}$}

Table 4.21 summatizes the baseline calculations. The coal and nuclear* systems are two to five times more efficient than the solar energy systems but

*Only the LWR was studied in detail; the LMFBR, despite having higher capital energy costs, should at least break even due to lower fuel energy costs; LMFBR fuel is produced by chemical separation, which is less energy intensive than the diffusion process needed to enrich fuel for the LWR. 
Table 4.21. Summary of Energy Balance Data

\begin{tabular}{|c|c|c|c|c|c|}
\hline \multirow[b]{2}{*}{ Parameter } & \multirow{2}{*}{$\begin{array}{l}\text { Nuclear, } \\
\text { LWR }\end{array}$} & \multirow{2}{*}{$\begin{array}{l}\text { Coal, } \\
\text { CG/CC }\end{array}$} & \multirow{2}{*}{$\begin{array}{c}\text { Terrestrial } \\
\text { Solar, } \\
\text { Photovoltaic }\end{array}$} & \multicolumn{2}{|c|}{ SPS } \\
\hline & & & & silicon & GaAlAs \\
\hline Gross efficiency ${ }^{b}(\%)$ & 22 & 37 & 6 & 7 & 7 \\
\hline Operating efficiencyc $(\%)$ & 20 & 33 & 6 & 7 & 7 \\
\hline Operating ratiod & 3 & 4 & 27 & 17 & 78 \\
\hline Lifetime efficiency $(\%)$ & 20 & 33 & 5 & 7 & 7 \\
\hline Lifetime ratiof & 3 & 3 & 1 & 4 & 18 \\
\hline Payback periodg - & & & & & \\
\hline Electric basis (yrs) & 1 & 1 & 20 & 6 & 1 \\
\hline
\end{tabular}

Source: Ref. 126.

${ }^{a}$ Silicon system.

${ }^{b}$ Annual net output/annual primary input.

CAnnual net outpul/annual primary, operating; internal inputs.

dAnnual net output/annual operating, internal inputs.

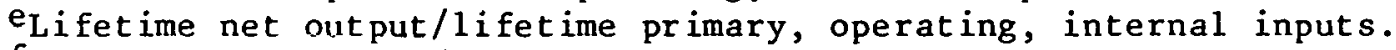

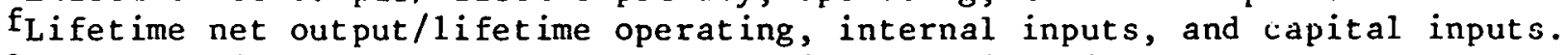

gTime at which net output equals operating + capital inputs.

operate on nonrenewable resources. The calculation of efficiency for each system is not sensitive to the gross, operating, or lifetime calculations. The conversion efficiency of the system dominates the result.

The operating ratio calculation shows that the solar energy systems require substantially less operating energy per unit of electrical output. However, the 1 ifetime ratio calculation shows that the intensive capital investment reduces their energy ratios significantly. The payback period for al1 systems except SPS/Si and terrestrial photovoltaic is less than 1.5 years. In both of these cases, sensitivity analysis shows that long. payback is dominated by the energy intensity of silicon cell'production. A number of possibililies, including reduction in overall cell production energy requirements, the use of solar-generated electricity in place of conventional electrical power for cell manufacture, increased cell 1 ifetime, and decreased silicon requirements could reduce the SPS/Si payback period to a level comparable to the other systems (i.e., one to two years); the best combination of conditions for the terrestrial photovoltaic system would still result in a payback of about six years. 125

\section{Comparison to Other Studies}

of particular interest is comparison of these SPS results with those of previous studies. Direct comparison is difficult because each study is based on a different. reference design and methodology. Some approximate comparisons can be made, noting the major sources of difference. 
A Planning Research Corporation study 130 used $I / 0$ analysis of a GaAlAs SPS. The study assumed higher energy intensities and resulted in a 2.5 year payback (vs. 1.3 years calculated here).

Herendeen 128 used $I / O$ analysis and uncertainty to quantify the lifetine ratio between 0.7 and 6.6 with a mean value of 2.1 , for a $10-G W$ SPS. This is surprisingly close to the result here of 4.0 , considering major differences in the assumption about silicon cell life. Herendeen assumed an exponentially decreasing cell power output over a 30-year lifetime. This analysis assumes maintenance to obtain constant power output and a 30 -year life.

A Jet Propulsion Lab (JPL) study 127 computed a payback perind in the rangc of 1.2 tu 1.6 years for a system of 48 10-GW silicon satellites (vs. 6.4 years here). There are three major contributors to this difference. JPL assumes a reduction in energy requirements for silioon productivu by abour a factor of four over present requirements and half as much silicon. Most importantly, JPL converts electrical energy to a thermal equivalent by multiplying by a factor of three. Removing only this last difference results in a payback of 3.6 to 4.8 years for the JPL study.

\section{Summary}

The current state of knowledge indicates that energy balance is not a significant factor precluding the development of certain coal, nuclear, and satellite power systems. There are indications that reductions in energy requirements for silicon cell production will be needed since thoee rcquire* menls consitute a large factor in net energy salculation for gilicon systems. In addition, although current data indicate that GaAlAs cells provide a viable alternative, further studies are warranted because information on the energy requirements of these cells is extreinely limited.

In conclusion, the net energy analysis has shown that the SPS system with silicon cells is a viable alternative, having a payback period substantially smaller than its lifetime; a TPV system using silicon cells does not look as attractive. However, if the most optimistic projections were realized for silicon cell production, the TPV option would become a viable alternative from an energy balance perspective.

If development of a gallium photocell proceeds as currently projectcd, all SPS system with GaAlAs cells will result in a payback period romparable to $C C / C C$ and uuclear. In any event, the sYS is a viable alternative using state-of-the-art technologies, with promise of even better technology in the foreseeable future.

\subsubsection{Water}

The objective of the water assessment is to determine the quantity of water used and the quality of water returned during the complete fuel cycle for SPS and alternative technologies. A complete specification of the water issue involves the items listed in Table 4.22. For this preliminary assessment, only aggregated numbers for withdrawal and consumption (portion of water 
withdrawn that is not returned) were determined. The numbers were derived from preliminary engineering studies at Argonne National Laboratory.

Results are listed in Table 4.23. Either natural or mechanical draft cooling towers are assumed; process requirements are also included. No withdrawal or consumption is shown for TPV or SPS; actual requirements for cleaning not provided by rain are expected to be negligible. The nuclear technologies are similar in their water requirements, utilizing about twice as much water as ' $\mathrm{CG} / \mathrm{CC}$.

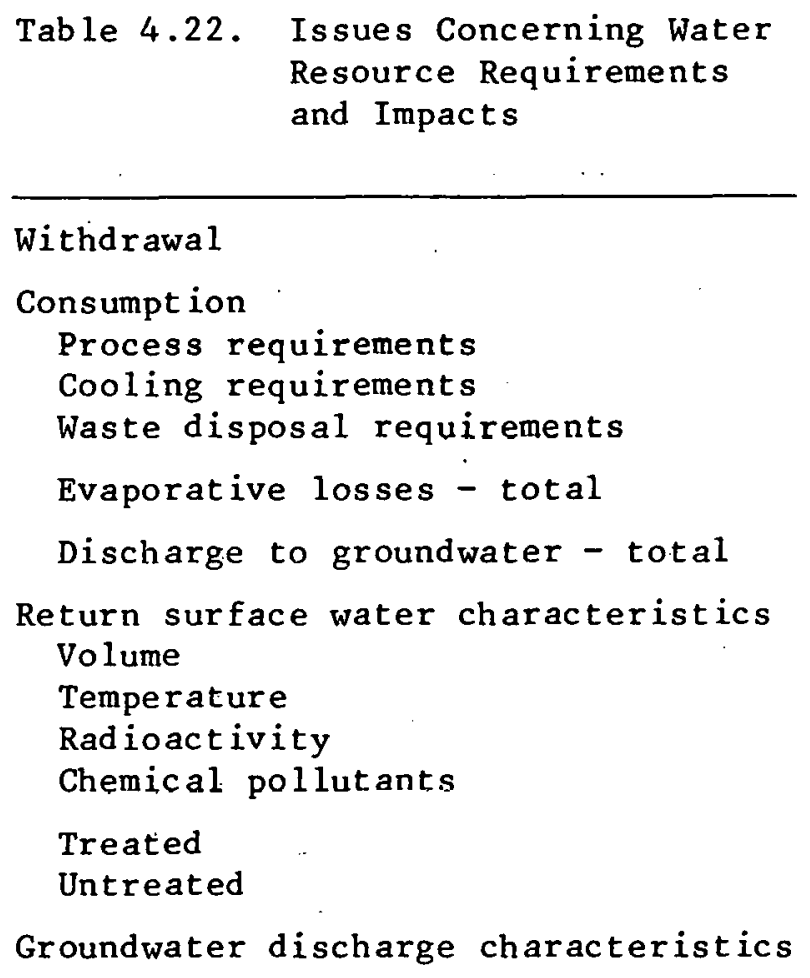

Table 4.23. Water Resource Reyuilemenls fur SPS and Alternative Technologies

\begin{tabular}{lcc}
\hline & Water Required & $\left(1000 \mathrm{~m}^{3} /\right.$ day \\
\cline { 2 - 3 } Technology & Withdrawal & Consumption \\
\hline $\begin{array}{c}\text { Light water reactor } \\
\begin{array}{c}\text { Coal gaoification/ } \\
\text { combined cycle }\end{array}\end{array}$ & 100 & 60 \\
$\begin{array}{c}\text { Liquid metal fast } \\
\text { breeder reactor }\end{array}$ & 50 & 30 \\
$\begin{array}{c}\text { Terrestrial } \\
\text { photovoltaics }\end{array}$ & 100 & 60 \\
Satellite Power System & 0 & 0 \\
\hline
\end{tabular}


Not yet quantified but extremely important is the question of the quality of water discharged to the surface and groundwater tables. Temperature, radioactivity, and chemical content will be addressed in future assessments.

\subsubsection{Labor}

The objective of the labor analysis was to address the supply and demand characteristics for various types of skills needed for SPS and alternative energy technologies. The concern is not with the numbers of people required in each category, which is an employment question, but current and likely trends influencing the availability of people with specific skills.

It is important that the choice of an energy technology clusely watch available skills. If likely deficiencies are determined, then measures must be taken to develop skills required in a timely fashion. It might also be desirable to avoid a surplus of skills of a certain type and the resultant underutilization of the work force.

All of the energy technologies require heavy construction skills; SPS has the additional need for space-construction personnel, a work force that does not exist. Programs would have to be instituted to train people for this activity and then provide for their subsequent careers. Skills required to operate and maintain terrestrial systems and components should pose no particular problems; the nuclear industry has been able to acquire the highlyskilled people needed.

\subsection{MACROECONOMIC AND SOCIOECONOMIC ISSUES}

Section 4.1 described the comparativc dircct encrgy coet and performance of alternative technologies. In addition to the economic effect of higher electricity charges to consumers, there are other economic issues that result from the development, deployment, and utilization of energy technologies. These issues are: (1) the direct and indirect system dollar costs on the national economy (macroeconomic issues) and (2) the monetary impact and social stresses on localitles where energy system elemeuls are sited (socio economic issues).

Some analyses were performed to quantitatively assess the effects that deployment of the SPS or its alternatives will have on the national economy of the 21 st century. Huwever, the results were extremely limitad lii value dus to the highly restrictive assumptions that had to be made. Thus, this section has been scoped to deal only with the issues in qualitative terms and to indicate the likely direction of future analysis based on carefully constructed scenarios.

\section{Macroeconomic Issües}

Macroeconomic effects are measured by changes in GNP flow, unemployment rates, and inflation rates. Indirect system dollar costs are all 
infrastructure, residual pollution, resource, and monetary welfare costs that could affect the economy. Certain macroeconomic effects are considered at the regional (Census Bureau regions) and income class levels as well as at the national level.

National Macroeconomic Issues. Significant effects on the national economy due to energy production are likely. However, the nature of those effects will depend not only on system differences but also on the assumed economic scenario. For example, the scenario must resolve such issues as the following:

- Is the economy operating at full capacity?

- Are the systems financed by the private or public sector?

- Are government costs recovered from ratepayers or taxpayers?

- Does the Federal Reserve Board (FRB) accommodate the investment demands by adding to the money stock?

Regional Macroeconomic Issues. The principal issues are:

- What are the comparative costs and benefits of each system for each major U.S. region during the development and construction phases? Significant differences could arise if, e.g., the system is financed by taxes from all regions but employment is concentrated in one or two regions.

- What are the comparative power costs (relative to current power costs) for each region under various assumptions about the burdens of ratepayers and taxpayers?

Income-Class Macroeconomic Issues. The principal issues are:

- How will the nature of each system affect the employment opportunities for various income classes during the development and construction phases?

- What will be the comparative effects of SPS and its alternatives on the disposable income (after payment of taxes and power bills) of various income classes?

The effect of power costs on lower-income groups is of particular importance., Burden fractions could be estimated by assuming stable relationships between income received and taxes and utilities paid without advanced power systems (e.g., SPS, fusion, TPV). The magnitude of the burden would then be estimated from the direct and indirect system costs and the types of ownership and subsidies assumed. Finally, the magnitudes of the population classes affected could be inferred from demographic projections and forecasts of income distributions. 


\section{Socioeconomic Issues}

Overall, a socioeconomic assessment concerns the effects of various power options on the financial and social lives of the populations living in the vicinity of energy system sites. Financial effects include public infrastructure costs and effects on local employment, wages, prices, and property values. Social stresses can result from rapid growth, changes in local political structure, and cultural changes. Effects such as local inflation, crime rates, community structural changes, and labor migration have occurred in the past.

\section{Future Economic/Societal Assessments}

The economic and soctetal assessment of the effects of alternative. technologies in the next 50 years must include the development of scenarios (e.g., economic state-of-the-world variables and energy siting). However, the analysis will only be as accurate as the scenario information. Indirect effects must be considered to clarify the economic commitment necessary for a particular technology.

\subsection{INSTITUTIONAL ISSUES}

\subsubsection{Introduction}

The relative institutional impacts of energy technologies are becoming increasingly important in the assessment of policy priorities for federal. research, development, and demonstration expenditures. The environmental impact statement process created by the Nationai Environmental Policy Act of 1969 (NEPA) has been interpreted in many legal opinions to require the consideration of factors beyond air and water pollution. Institutional impacts fall within this spirit, even if they are not covered by the letter of the law.

There is a practical, as well as legal, basis for institutional analysis of new energy technologies. Carefully laid plans to make fission reactors a major electricity source have been stymied in part because of a failure to appreciate fully the ways in which numerous regulatory agencies would respond to the difficult choices posed by that energy technology. A recent publication of a nuclear industry trade organization, the Atomic Industrial Forum, 131 alleges that government regulation accounted for an increase in nuclear power plant engineering man-hours of nearly $40 \%$ in the 1970 s alone. Thus, a comparative assessment of the contribution of the satellite power system to the nation's energy resources should include a discussion of the effects of energy technology deployment on existing and potential regulatory institutions and the effects of these institutions on the deployment of energy technologies.

This section will compare the regulatory issues surrounding electricity systems based on the SPS, coal, light water or breeder reactors, and centralized terrestrial photovoltaics. The comparison is based on the assumption 
that decision makers who must choose between energy technologies are interested primarily in the significant differences between those technologies, not in a complete catalogue of all of their characteristics. In the case of institutional analysis, this means that the most relevant information is that which highlights the different responses of regulatory institutions to different energy technologies and projects the impact of these institutions on deployment.

To perform this analysis, it is necessary to imagine the regulatory scheme for each technology at the same stage of development. Therefore, this analys is is divided into two parts. Section 4.6.2 will compare the regulations for each technology as they exist at present, without regard to probable future areas of regulatory activity. Section 4.6 .3 will attempt to evaluate how national trends are likely to influence technology regulation in the near future.

\subsubsection{Comparison of Present Regulatory Schemes}

Approach. Analysis of the overall regulatory schemes associated with different technologies will focus on three areas:

- The justifications for government regulation of energy technology.

- The level of government that is primarily responsible for the regulatory task.

- Where possible, the cost of regulation to both the government and the owner of the electricity system.

For the purposes of this section, the term "government regulation" is defined as any conscious and systematic government effort to influence the development and deployment of an energy technology that would otherwise be left to evolve in the private market place.

Justifications for Regulation. A recent article by Stephen Breyer 132 represents one of the most up-to-date efforts at an overview of our regulatory institutions. He organizes regulations into a number of categories, each of which represents a distinct justification for regulation. Justifications, he points out, consist of the best "public interest" arguments of those who have advocated regulatory measures, regardless of whether these reasons actually motivated the governmental action. In effect, these justifications represent the best rhetorical policy explanation of why government does what it does.

Breyer defines a number of regulatory categories that are not applicable to the issues being considered here. For the purposes of this section, his regulatory justifications can be reduced and adapted to three:

- Control of Monopoly Power. This category includes all of the numerous forms of regulation intended to control the freedom of monopolies or to restrict competition in favor of monopolies. 
- Correction for Externalities.

Any government-imposed requirement intended to prevent the general public from paying for costs that are more properly assumed by the entity that creates them. Environmental control regulations, for example, are included in this category.

- Correction for Inadequate or Improper Information. This category. covers all regulations intended to promote the free flow of information for its own sake or to restrict the free flow of information for national security purposes.

Regulations effectuated primarily through the tax system are not included in this discussion, except where specifically noted.

Level of Government. Each type of regulation for each electricity system will be classified by the level of government that has primary juriediction for enfurcing 1t. l,ncal, statc, federal, and incernational governmental bodies will be covered. Hybrid bodies, such as regional agencies or federal laws that are enforced by state agencies, are classified at the level of government that has the most direct power over their conduct. For example, the clean air laws are considered federal regulations even though State Implementation Plans guide their use, because the federal government sets the standards those plans must meet.

Cost of Regulation. A rough estimate of the annual cost of each justification for federal regulation will be included for coal and nuclear technologies. The figures listed will rover both the measuitule coscs to taxpayers through the operation of the federal government and the compliance costs to industry. A fourth category, "hybrid purposes," will include funding levels for programs that fulfill all three of the justifications for regulations discussed above but which could not be broken down more specifically.

These figures must be interpreted with extreme caution because their statistics are derived largely from untested sources and thus may be incomplete. Their sole purpose is to enable comparisons of the differences between orders of magnitude of the coots of regulating these energy resources.

Results. As Tables 4.24-4.27 indicate, substantially different regulatory systems are associated with the four different electricity production systems under consideration. The regulatory systems differ both in the overall burden of regulation and in the levels of government that have primary jurisdiction over different aspects of regulation. Under the least favorable circumstances, significant and unprecedented regulatory burdens and conflicts could accompany the establishment of SPS.

Obvious regulatory difficulties inevitably would accompany SPS deployment because of its international character. As Tables 4.24 and 4.26 indicate, neither coal nor centralized terrestrial photovoltaic electricity production systems' are faced with any significant regulation by international bodies. Although Table 4.25 reveals that light water and breeder reactors are 
Table 4.24. Justifications for Regulating Coal Technologies at Each Level of Government

\begin{tabular}{|c|c|c|c|c|}
\hline Justification & Lccal & State & Federal & International \\
\hline $\begin{array}{l}\text { Control of } \\
\text { Monopoly Power }\end{array}$ & None & $\begin{array}{l}\text { Certificate of need, } \\
\text { Antitrust, } \\
\text { Retail electric rates. }\end{array}$ & $\begin{array}{l}\text { Antitrust, } \\
\text { Coal leases on federal land, } \\
\text { Wholesale electric rates, } \\
\text { Research and development funding. }\end{array}$ & None \\
\hline $\begin{array}{l}\text { Correction for } \\
\text { Externalities }\end{array}$ & Land Use & $\begin{array}{l}\text { Mine and miner health } \\
\text { and safety. }\end{array}$ & $\begin{array}{l}\text { Environmental impacts of surface } \\
\quad \text { and underground mining, } \\
\text { Air and water pollution discharges, } \\
\text { Worker safety, } \\
\text { Endangered species protection, } \\
\text { Research and development funding, } \\
\text { Equal employment opportunity. }\end{array}$ & None \\
\hline $\begin{array}{l}\text { Correction for } \\
\text { Inadequate or } \\
\text { Improper Infor- } \\
\text { mation }\end{array}$ & None & Mining claims. & $\begin{array}{l}\text { Corporate securities disclosure, } \\
\text { Freedom of information, } \\
\text { Patent protection, } \\
\text { Research and development funding. }\end{array}$ & None \\
\hline
\end{tabular}


Table 4.25. Justifications for Regulating Light Water or Breecer Reactors at Each Level of Government

\begin{tabular}{|c|c|c|c|c|}
\hline Justification & Locel & State & Federal. & International \\
\hline $\begin{array}{l}\text { Control of } \\
\text { Monopoly Power }\end{array}$ & None & $\begin{array}{l}\text { Certificate of need, } \\
\text { Antitrust, } \\
\text { ketail electric rates. }\end{array}$ & $\begin{array}{l}\text { Antitrust, } \\
\text { Wholesale electric rates, } \\
\text { Research and development. funding. }\end{array}$ & $\begin{array}{l}\text { Nuclear non- } \\
\text { prolifera- } \\
\text { tion treaty. }\end{array}$ \\
\hline $\begin{array}{l}\text { Correction for } \\
\text { Externalities }\end{array}$ & $\begin{array}{l}\text { Land Use, } \\
\text { Nuclear } \\
\text { materials } \\
\text { transport }\end{array}$ & $\begin{array}{l}\text { Nuclear materials } \\
\text { transport, } \\
\text { Industrial waste dis- } \\
\text { charge, } \\
\text { Nuclear waste disposal. }\end{array}$ & $\begin{array}{l}\text { Nuclear materials trarsport, } \\
\text { Siting, } \\
\text { Operation, } \\
\text { Insurance, } \\
\text { Air pollution discharge, } \\
\text { Water pollution discherge, } \\
\text { Worker safety, } \\
\text { Nuclear waste disposal, } \\
\text { Power plant decommissioning, } \\
\text { Power plant control diring Đmergencies, } \\
\text { Endangered species prctection, } \\
\text { Research and development. funding, } \\
\text { Equal employment opportunity. }\end{array}$ & $\begin{array}{l}\text { Nuclear non- } \\
\text { prolifera- } \\
\text { tion treaty. }\end{array}$ \\
\hline $\begin{array}{l}\text { Correction for } \\
\text { Inadequate or } \\
\text { Improper Infor- } \\
\text { mation }\end{array}$ & None & $\begin{array}{l}\text { Emergency evacua- } \\
\text { tion procedures. }\end{array}$ & $\begin{array}{l}\text { Corporate securities cisclosure, } \\
\text { National security restrictions, } \\
\text { Freedom of informatior., } \\
\text { Patent protection, } \\
\text { Research and development funding. }\end{array}$ & $\begin{array}{l}\text { International } \\
\text { Atomic Energy } \\
\text { Agency. }\end{array}$ \\
\hline
\end{tabular}


Table 4.26. Justifications for Regulating Terrestrial Photovoltaics at Each Level of Government

\begin{tabular}{|c|c|c|c|c|}
\hline Justification & Lo:al & State & Federal & International \\
\hline $\begin{array}{l}\text { Control of } \\
\text { Monopoly Power }\end{array}$ & Noze & $\begin{array}{l}\text { Certificate of need, } \\
\text { Antitrust, } \\
\text { Retail electric rates. }\end{array}$ & $\begin{array}{l}\text { Antitrust, } \\
\text { Utility interconnection for de- } \\
\text { centralized plants, } \\
\text { Wholesale electric rates, } \\
\text { Research and development funding. }\end{array}$ & None \\
\hline $\begin{array}{l}\text { Correction for } \\
\text { Externalities } \\
\qquad \quad \therefore\end{array}$ & Land Use & $\begin{array}{l}\text { Industrial waste } \\
\text { discharge from } \\
\text { cell production. }\end{array}$ & $\begin{array}{l}\text { Air pollution discharge, } \\
\text { Water pollution discharge, } \\
\text { Worker safety, } \\
\text { Endangered species protection, } \\
\text { Research and development funding, } \\
\text { Equal employment opportunity. }\end{array}$ & None \\
\hline $\begin{array}{l}\text { Correction for } \\
\text { Inadequate or } \\
\text { Improper Infor- } \\
\text { mation }\end{array}$ & None & None & $\begin{array}{l}\text { Corporate securities disclosure, } \\
\text { Freedom of information, } \\
\text { Patent protection, } \\
\text { Research and development funding. }\end{array}$ & None \\
\hline
\end{tabular}


Table 4.27. Justifications for Regulating SPS at Each Level of Government

\begin{tabular}{|c|c|c|c|c|}
\hline $\begin{array}{l}\text { Control of } \\
\text { Monopoly Power }\end{array}$ & None & $\begin{array}{l}\text { Certificate of neec, } \\
\text { Antitrust, } \\
\text { Retail electric rates. }\end{array}$ & $\begin{array}{l}\text { fntitrust, } \\
\text { Financial structure and decision- } \\
\text { making process of SPS governing } \\
\text { entity, } \\
\text { Wholesale electric rates, } \\
\text { Research and development funding. }\end{array}$ & $\begin{array}{l}\text { Orbit avail- } \\
\text { ability, } \\
\text { Radio frequency } \\
\text { allocation. }\end{array}$ \\
\hline
\end{tabular}


subject to certain international restrictions on proliferation and information disclosure, basic decisions, such as reactor location, damage liability in the event of accident, and permissible emissions, are made within the United States. Only SPS appears to require an internationally-empowered body to make the types of decisions listed in Table 4.27 -- decisions which, like orbit availability, would vest in foreign countries control over the right to produce and transmit energy. The United States Government would have to be prepared to accept the inevitable extra bureaucratic delay that accompanies such complex decisions, without the ultimate authority to short-circuit normal procedures as it did in the case of the Trans-Alaska Pipeline. This predictable delay could come exactly at a time when a swift reduction in domestic dependence on foreign oil supplies is a fundamental national policy goal.

Moreover, the international regulation of the SPS is likely to increase the level of regulation required at the federal level. As Table 4.28 indicates, the 1967 Treaty on Principles Governing the Activities of States in the Exploration and Use of Outer Space, Including the Moon and Other Celestial Bodies and the 1972 Convention on International Liability for Damage Caused By Space Objects both guarantee that the United States Government will pay for damages resulting from any SPS activities undertaken with its assistance, regardless of negligence and regardless of the extent of direct government sponsorship. It is logical to assume that the federal government will insist on a powerful voice in the operation of any entity which, like the SPS, could incur substantial liability for which American taxpayers would ultimately be responsible.

Table 4.28 lists the similarities and differences between the costs of regulating coal and regulating nuclear-generated electricity. This comparison has important implications for SPS. Although the costs associated with each justification for regulation make up about the same percentage of the total cost of regulating coal as for regulating the nuclear-derived electricity, the total costs associated with the nuclear option exceed those of the coal option by more than 50\%. Moreover, the bulk of the extra money spent on nuclear regulation appears to be concentrated in two areas of justification --. "correction for externalities" and the "hybrid purpose" categories.

The reasons for these differences between costs for coal-electric and nuclear-electric regulation. could provide important indications of what would happen if an SPS system were deployed. If the specific programs within the nuclear "correction for externalities" and "hybrid purpose" categories are examined, it becomes apparent that the bulk of spending is on various research and development activities. Programs like back-end fuel cycle waste management and civilian reactor development account for a large percentage of the total costs in their respective categories. Coal regulatory costs, on the other hand, result from regulations aimed mainly at mitigating adverse impacts that already are relatively well-organized, such as miner health and safety protection and controlling surface mining externalities.

The fact that a large portion of the nuclear regulatory spending is on research and development activities intended to improve safety may reflect a more general concern that could also affect the SPS. Nucleargenerated electricity is one example chosen by Talbot Page in a recent article139 to illustrate the "zero-infinity dilemma," which. Page defines as the 
Table 4.28. Comparative Cost Estimates for Federal Regulations of Ccral and Light Water Reactor Electicicity Production Systems $\left(10^{6}\right.$ Dollars $\left.(19 ; 8) / y r\right)$

\begin{tabular}{|c|c|c|c|c|c|c|c|}
\hline Justification & Coal-Fired E-ectrictty & $\begin{array}{c}\text { Cost oz } \\
\text { Regulatior. }\end{array}$ & $\begin{array}{l}\text { \% of Total } \\
\text { Cost of } \\
\text { Regula:ion }\end{array}$ & $\begin{array}{l}\text { Light Water or } \\
\text { Breeder Feactor Electricity }\end{array}$ & $\begin{array}{c}\text { Cost of } \\
\text { Fegulation }\end{array}$ & $\begin{array}{l}\% \text { of Total } \\
\text { Cost of } \\
\text { Regulation }\end{array}$ & $\begin{array}{l}\text { Total Cost of } \\
\text { Justification } \\
\text { (\% Coal, \% Nuclear) }\end{array}$ \\
\hline $\begin{array}{l}\text { Control of } \\
\text { Monopoly Power }\end{array}$ & $\begin{array}{l}\text { Caal Leases on Fedezal Lards } \\
\text { Deplet lon Allowances Rever.ue Equ=valent }\end{array}$ & $\begin{array}{l}32.3^{a} \cdot t \\
443.0^{a}\end{array}$ & & $\begin{array}{l}\text { Uranium Enrichment } \\
\text { Advanced Isotope Separation }\end{array}$ & $\begin{array}{l}220 . c^{e} \\
39.2^{z}, e\end{array}$ & 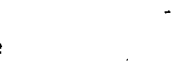 & \\
\hline & Total & 475.3 & 13.3 & Total & 259.2 & 4.3 & $734.5(64.7,35.3)$ \\
\hline $\begin{array}{l}\text { Correction for } \\
\text { Externalities }\end{array}$ & $\begin{array}{l}\text { Office of Surface Mining } \\
\text { Pollution Control (AIr, Water) } \\
\text { lilner Health and Sa:ety (CSHA, IILSA) } \\
\text { Domestic, Foreign Waterwas Sutisidy } \\
\text { Coal Hydrology }\end{array}$ & $\begin{array}{c}2,290.4^{\mathrm{c}} \\
66.9^{\mathrm{d}} \\
113.5^{\mathrm{a}} \cdot \mathrm{t} \\
90.8^{\mathrm{a}} \\
13.2^{\mathrm{a}}\end{array}$ & . & $\begin{array}{l}\text { Waste liagement } \\
\text { Nuclear llaterials Transport } \\
\text { away from Reactor Storage } \\
\text { Encapsulation Facility } \\
\text { Geologic Repository } \\
\text { Overhead } \\
\text { Decommissioning } \\
\text { Insurance (potential liability } \\
\text { Site Safety Research }\end{array}$ & 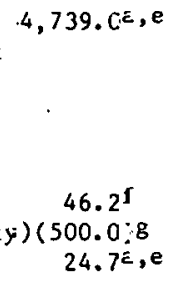 & 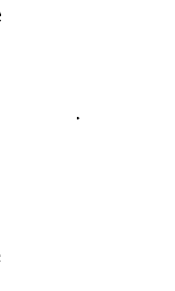 & \\
\hline & Total & $2,574.8^{\mathrm{h}}$ & (5.1) & Total & $4,809.9$ & 79.0 & $7384.7(34.9,65.1)$ \\
\hline $\begin{array}{l}\text { Correction for } \\
\text { Insuffictent } \\
\text { Information }\end{array}$ & Data Collection and Analysis & $29.0^{a, t}$ & & Uraniun Resource Assessment & $24.7^{\varepsilon}$ & & \\
\hline & Total & 29.0 & 0.3 & Total & 24.7 & 0.4 & $53.7(54.0,46.0)$ \\
\hline $\begin{array}{l}\text { Hybrid } \\
\text { Purpose }\end{array}$ & $\begin{array}{l}\text { Coal Utilization Research and } \\
\text { Development }\end{array}$ & $354.5^{\mathrm{a} . \mathrm{t}}$ & & $\begin{array}{l}\text { Nuclear Regulatory Commission } \\
\text { Regulations } \\
\text { Civilian Reactor Development } \\
\text { Nuclear laterials Research }\end{array}$ & $\begin{array}{l}240.0^{\epsilon} \\
684.3^{E}, \mathrm{e} \\
68.4^{E}, \mathrm{e}\end{array}$ & & . \\
\hline & Total & 354.5 & 10.3 & Total & 992.7 & 16.3 & $1347.2(26.3,73.7)$ \\
\hline$\cdot$ & Total Cost of Regulation & $3,433.6$ & ICO & Total Cost of Regulation & $6,085.5$ & 100 & $9519.1(36.1,63.9)$ \\
\hline
\end{tabular}

asource: Ref. 133.

bSource: Ref. 134. While no spezif:c figtres vere used from this scurce jecause they have not yet been approved, they provided a source of comparion for the fuedre.

'Sources: Ref. 135; Joe Jewkes, Jf fice of Surface: llining, Office of the Budget, personal conwunication on revenues received from

fees of 35k/ton for surface-minet coal anc 15f:tan for undergrourd coal, July 13, 1979.

dSource: Ref. 136.

eSource: Ref. 137.

fource: Average of the various possible aetheds of decommissioning frcm kef. 137.

gSource: Ref. 138 .

hTh fs figure fails to Include costs attribttable to Equal Employatnt Opfortunity. While they are available, they were excluded

because of their relative insignificance. 
question of whether a decision to proceed with a technology should ever be made if that technology could result in a virtually infinite catastrophe even though the probability of such an event is virtually zero. It is clear that the United States Government has decided that a nuclear accident that results in a high-level radiation release into the environment would be infinitely costly and therefore intolerable; 140 the substantial spending on research and development illustrated by Table 4.28 testifies to the commitment of the government to reduce the probability of such an accident to zero by effective preventive measures.

It is exactly this approach to nuclear regulation that the nuclear industry claims has hamstrung its viability. Industry officials allege that the fears about accidents needlessly delay and drive up the cost of nuclear power plant construction, and such fears are considered to be the single biggest inhibition to deployment of the technology.

If the SPS is perceived to present a zero-infinity dilemma, it is probable that its regulatory costs will look much more like those of nuclear power (Table 4.28) than those of coal-fired electriclty. Like nuclear power, the SPS would be faced with continual regulation. The international character of SPS might further complicate the regulatory issue.

Of course, whether the SPS does present a zero-infinity dilemma as serious as nuclear power is a question on which there is no consensus. How serious an accident must be to become "catastrophic" and how small the probability to be viewed as "impossible" are political decisions that this study is intended to facilitate. It is important to recognize, however, that when a technology has come to be perceived as posing a zero-infinity dilemma, the total costs associated with regulating it could tecome a determinant of its economic viability.

\subsubsection{Regulatory Trends}

The comparative evaluation of the regulatory system that is likely to accompany any of the technologies considered here will continue to evolve. The extraordinary public attention that has been focused for a variety of reasons on energy production over the past ten years appears to be having a long-term. impact on the ways in which the problem is being perceived and resolved. The purpose of this section is to analyze some of these trends in a qualitative fashion.

In concluding that "the weight and importance of the decentralization trend in America is greater than the 150-year-old trend toward more centralization," John Naisbitt 141 calls attention to developments that have important implications for the regulatory system that would be associated with the SPS, as well as other electricity production technologies. Naisbitt states that if the decentralization trend continues, it is likely to cause intergovernmental conflicts in the regulation of all electricity technologies, but especially the SPS. He further contends that increasing decentralization probably will make uniform regulations more difficult than would otherwise be the case. of course, it is dangerous to draw too many conclusions from such recent developments. Nonetheless, it is important to understand their implications in the event they become long-term realities. 
Intergovernmental Conflicts. As Naisbitt 141 points out, numerous events suggest a growth of power among states and communities at the expense of the federal government. Increasing activity on the part of regions, states, and local governments is leading to greater assertion of decisionmaking authority by these entities. Naisbitt illustrates this trend with examples of states and localities that have tried recently to gain regulatory control over certain stages of the nuclear fuel cycle, including siting, transportation, and disposal of nuclear materials, and disaster emergency plans.

The present conflict between federal and local governments in the context of nuclear power could be even worse in the case of the SPS. Several studies 142-144 of the SPS have concluded that an international regulatory body probably would be desirable for regulation of the technology. If this move to centralize energy technology regulation comes at a time when the dominant national trend is exactly the opposite, substantial intergovernmental duplication and conflict could result, not only between the federal and local governments, but also between local governments and the international regulatory body. For example, Allan D. Kotinl45 suggests the possibility that states could attempt to regulate microwave exposure levels to their citizens -- an area ripe for international regulation if the SPS is deployed.

Such disputes, should they arise, could cause unexpected delays, costs, and uncertainties in the deployment of the SPS. While it is true that world-wide commitment to international regulatory bodies such as the Law of the. Sea Conference and the International Whaling Commission has grown in recent years, these bodies derive their authority to regulate the United States from the federal government. If the decentralization trend should continue, it is conceivable that state and local interests would reduce the ability of these international regulatory bodies to govern effectively. For example, recent litigation on behalf of Alaskan Eskimos to exempt their whaling activities from regulation by the International Whaling Commission may be decided in their favor, despite vigorous opposition by the federal government.

Non-Uniform Regulation. Regardless of whether the difficulties suggested above materialize, great potential exists for the SPS regulatory system, concurrent with other centralized energy technologies, to become more expensive than is predicted. Naisbitt141 concluded that governments "have stopped looking for the one best way to accomplish a particular social goal, and are now experimenting with a wide variety of approaches." If the decentralization trend continues, the regulatory system tor any of the electricity technologies covered in this section -- at whatever level of government that is vested with primary jurisdiction -- will likely have to be sufficiently flexible to meet this demand for individuality. The cost advantages of the uniform regulatory system that would normally evolve will be reduced as the system becomes unwieldy in the attempt to please widely divergent constituencies. Although the President has proposed a new regulatory body whose explicit purpose is to counteract this tendency, it is unclear whether his objective will be met. 


\subsubsection{Summary}

Institutional (regulatory) considerations are increasingly affecting the viability of new energy technologies. A comparison of regulatory schemes for the SPS, coal, nuclear, and terrestrial photovoltaic technologies suggests that the SPS could be faced with unprecedented regulatory burdens as a resulit of the number of jurisdictions that might seek to govern it, and the seriousness of its perceived hazards. Moreover, this trend could be exacerbated by the developing tendency of local governmental units to at tempt to gain regulatory control from the federal government. 
136

Blark 


\section{ASSESSMENT STATUS AND FUTURE DIRECTION}

The approach taken in this initial comparative assessment was to identify and qualify the key issues for the SPS and a limited number of central station baseload options. Initial issue selection was comprehensive; however, now that the preliminary comparison has established a base of knowledge about comparative issues, those that are found to be of lesser importance will not receive further study, and subsequent assessments will focus on key issues.

This section will describe the status of knowledge on each technology alternative and issue and discuss future directions for the comparative assessment. Many information gaps and uncertainties were discovered in conducting the preliminary comparative assessments. These gaps and uncertainties will be identified, and appropriate future studies will attempt to fill the important gaps and to lessen the uncertainties.

\subsection{TECHNOLOGY SELECTION AND CHARACTERIZATION}

This preliminary comparison was limited to a group of central station baseload alternatives -- coal (i.e., improved conventional combustion and coal gasification/combined cycle), nuclear. (i.e., PWR and LMFBR), terrestrial photovoltaics (central station), fusion, and the SPS -- to give reasonable dimensions to a large problem. However, the choice of alternatives may have been too narrow, and subsequent assessments will review this 1 ist to determine whether other alternatives should be considered. Decentralized technologies are the most noticeably absent from the list of alternatives. Some forms of cogeneration and decentralized photovoltaic systems are the prime candidates being considered. Although these are not central station baseload systems, they do represent alternative energy systems. However, an acceptable method for comparing decentralized and centralized technologies has not been estab1 ished. The integrated energy system and alternative futures approaches described in this report should provide an appropriate framework for comparing central station baseload and decentralized technology alternatives.

In addition to the strong consideration of decentralized alternatives, ceulcal station optlons will again be reconsidered to ensure that the most representative alternative has been selected from each class of alternatives not considered in the preliminary assessment (e.g., geothermal).

of the six technologies that were compared with the SPS in the preliminary assessment, fusion and terrestrial photovoltaic systems had weak characterizations. Since the comparison of these two alternatives was limited by availability of characterization information, these technologies will require improved definitions.

\subsection{COMPARATIVE ISSUE STATUS AND FUTURE DIRECTION}

The preliminary comparative assessment has provided a perspective of the technologies on an issue-by-issue basis. Tables 5.1 through 5.6 describe 
Table 5.1. Cost and Performarce -- Status, Uncertainties, and Future Direction 。

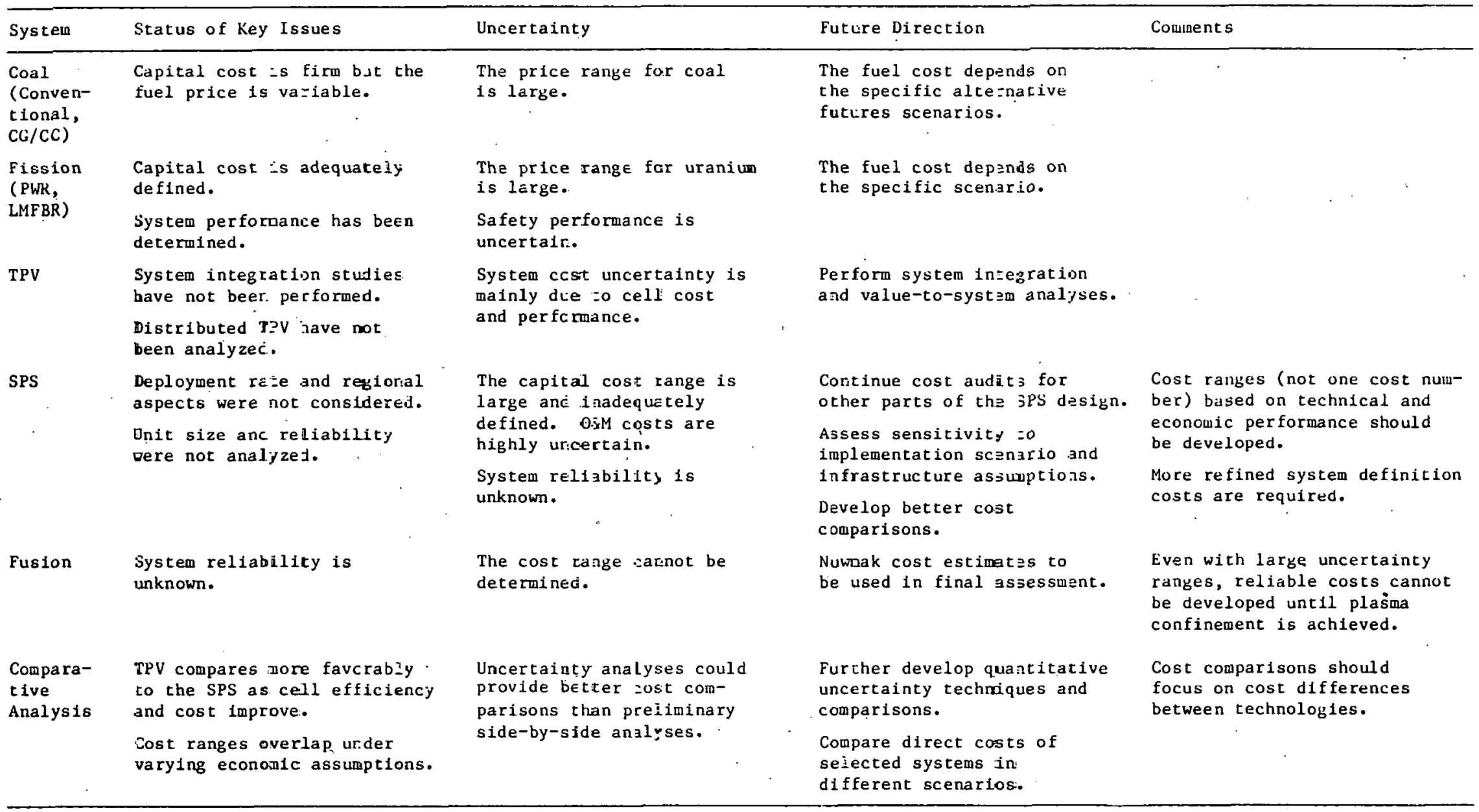


Table 5.2. Hea-th and Safety -- Status, Uncertainties, and Future Direction

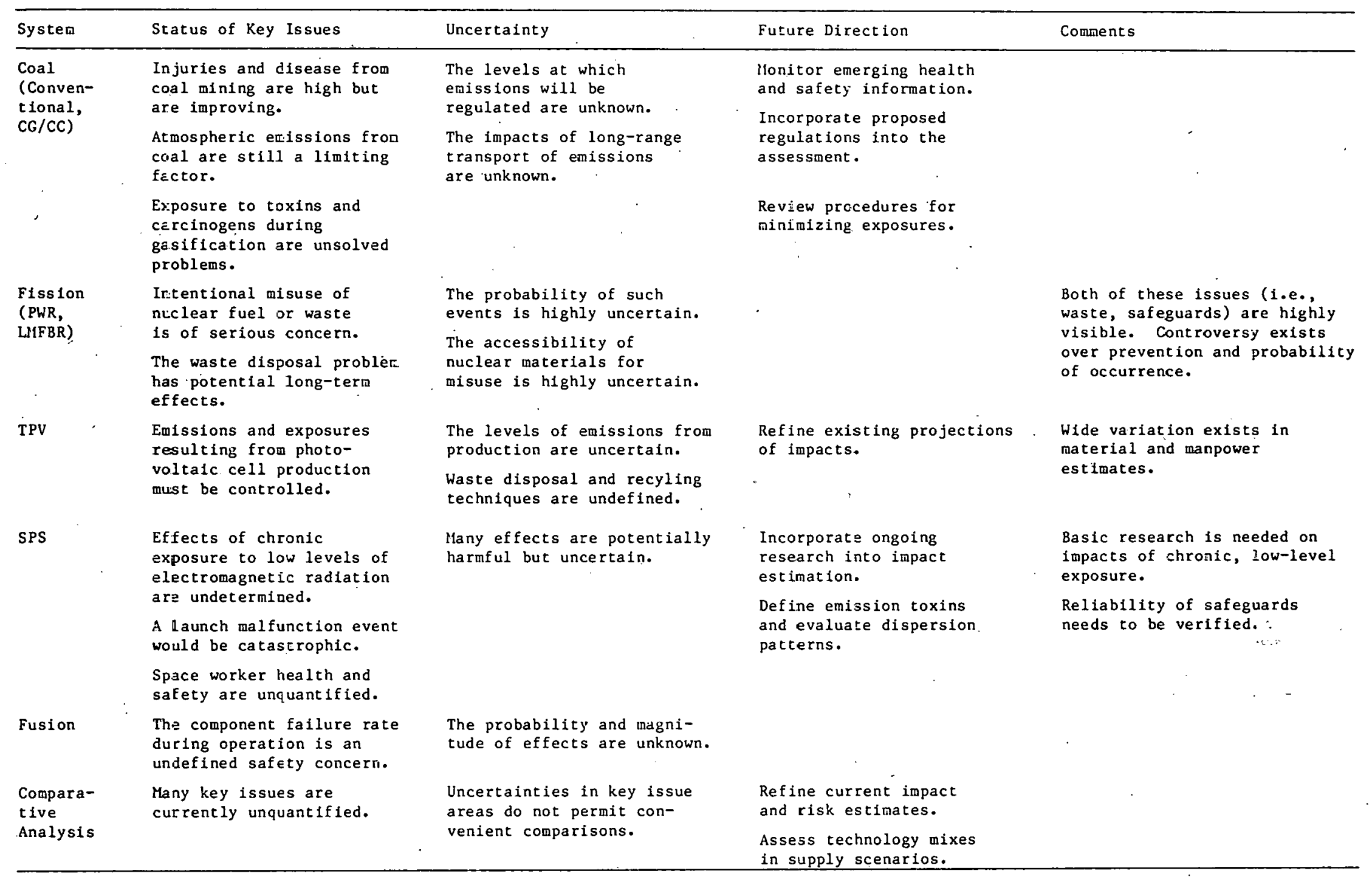




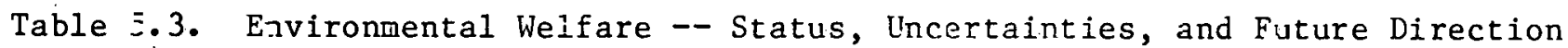

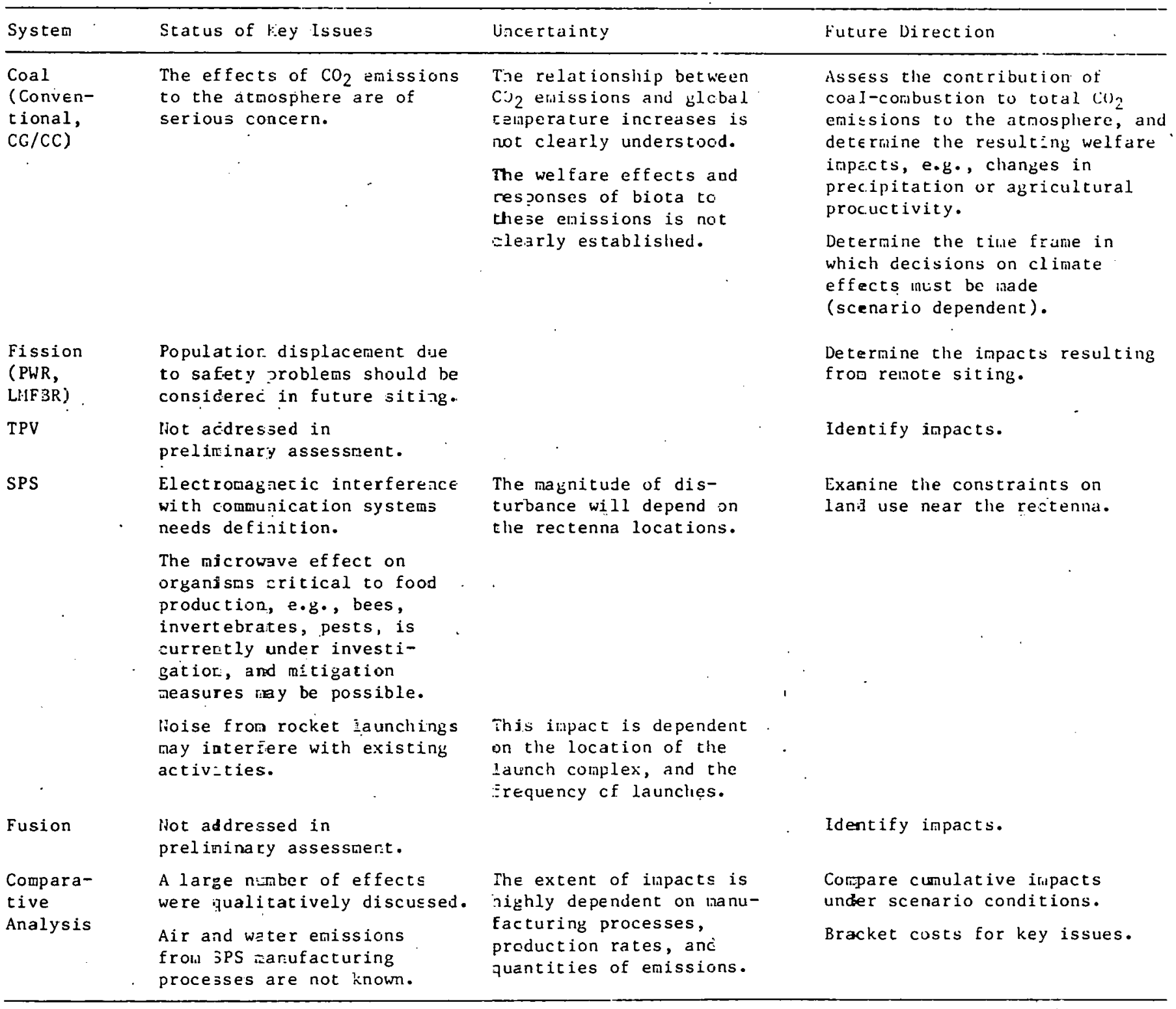


Table 5.4. Kesources -- Status, Uncertainties, and Future Direction

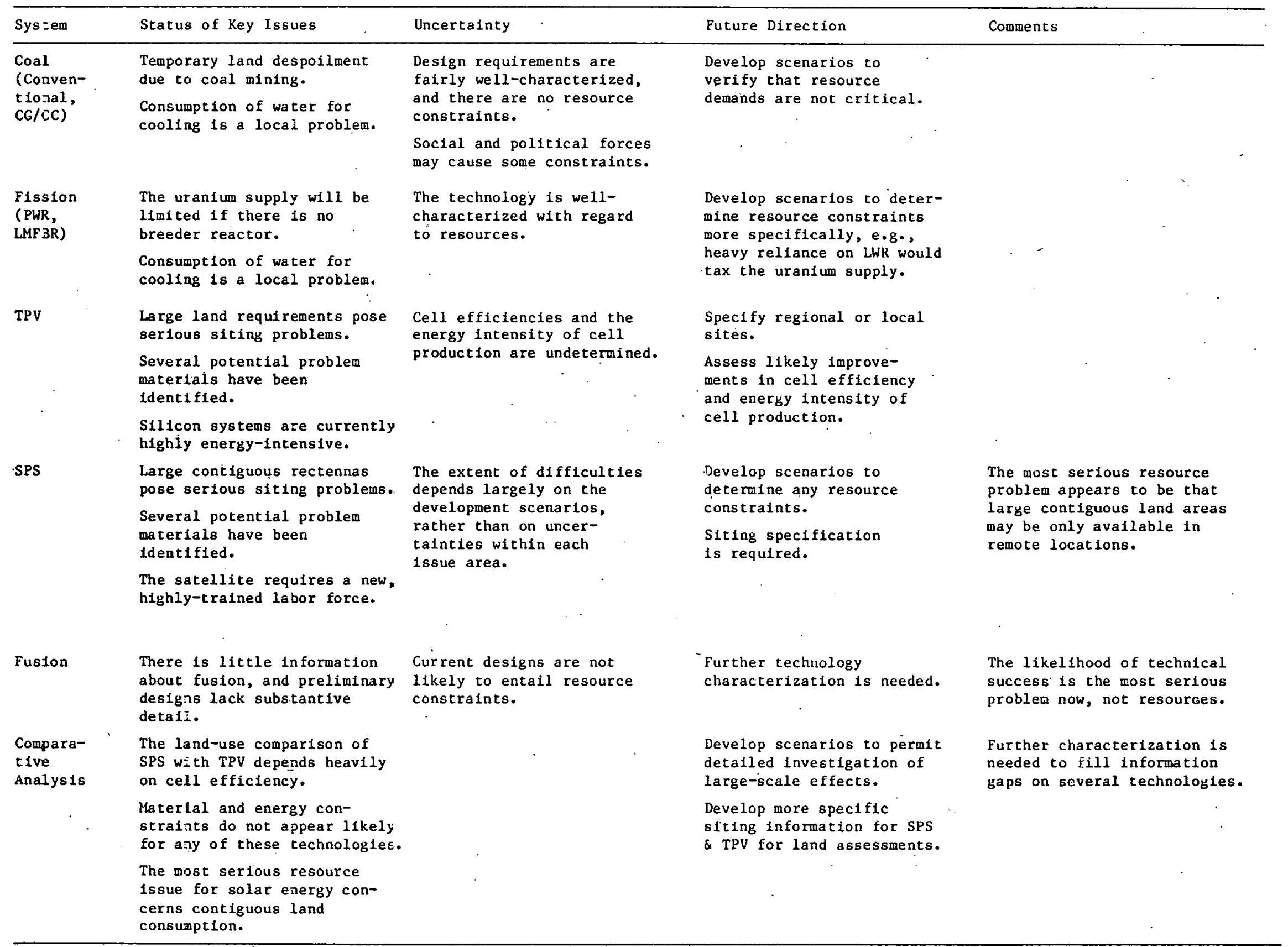


Table 5.5. Economic/Societal -- Status, Uncertainties, ar.d Future Direction

\begin{tabular}{|c|c|c|c|c|}
\hline System & Status of Key Issues & Uncerta:r.ty. & Future Direction & Comments \\
\hline $\begin{array}{l}\text { Coal } \\
\text { (Conven- } \\
\text { tional, } \\
\text { CG/CC) }\end{array}$ & $\begin{array}{l}\text { Regional econontc and } \\
\text { societal -mpasts will } \\
\text { probably be centered } \\
\text { in the West. }\end{array}$ & . & & 1 \\
\hline $\begin{array}{l}\text { Fission } \\
\text { (PWR, } \\
\text { LMFBR) }\end{array}$ & $\begin{array}{l}\text { Nuclear teahnology } \\
\text { is widely teployed. }\end{array}$ & , & & \\
\hline TPV & $\begin{array}{l}\text { Large capital invest- } \\
\text { ment is required. } \\
\text { Regional utillzaticn } \\
\text { expected. }\end{array}$ & $\begin{array}{l}\text { Industrial inz:astructure } \\
\text { is unknown. }\end{array}$ & . & \\
\hline Fusion & $\begin{array}{l}\text { Capital costs and infra- } \\
\text { structure investments } \\
\text { could af fe:t the econom?. } \\
\text { Reglonal effe=ts may } \\
\text { focus on } E \text { fe' areass. } \\
\text { Not covered. }\end{array}$ & $\begin{array}{l}\text { Infrastricture require- } \\
\text { ments we re not determined. }\end{array}$ & $\begin{array}{l}\text { Assess a scenario of } \\
\text { industrial infra- } \\
\text { structure developmen } \\
.\end{array}$ & $\begin{array}{l}\text { Systems definition should } \\
\text { supply industrial infra- } \\
\text { structure requirements. } \\
\qquad\end{array}$ \\
\hline $\begin{array}{l}\text { Compara- } \\
\text { tive } \\
\text { Analys 18 } \\
\ddots\end{array}$ & Not covered. . & $\begin{array}{l}\text { Indirect laves:-ment } \\
\text { is unknown. }\end{array}$ & $\begin{array}{l}\text { Assess the effects o: } \\
\text { direct and indirect } \\
\text { investment in differert } \\
\text { scenarios. } \\
\text { Specify facility sit:ng } \\
\text { to determine regiona- and. } \\
\text { loca economic and sociezal } \\
\text { effects. }\end{array}$ & . \\
\hline
\end{tabular}


Table 5.6. Institutional -- Status, Uncertainties, and Future Direction

\begin{tabular}{|c|c|c|c|c|}
\hline System & Status of Key Issues & Uncertainty & Future Direction & Comuents \\
\hline $\begin{array}{l}\text { Coal } \\
\text { (Conven- } \\
\text { tional, } \\
\text { CGiCC) }\end{array}$ & $\begin{array}{l}\text { Coal is already heavily } \\
\text { regulated. }\end{array}$ & & $\begin{array}{l}\text { Assess how the trend toward } \\
\text { decentralized decision } \\
\text { making could affect the } \\
\text { deployment scenario. }\end{array}$ & $\iota$ \\
\hline \multirow[t]{2}{*}{$\begin{array}{l}\text { Fission } \\
\text { (PWR, } \\
\text { LMFBR) }\end{array}$} & $\begin{array}{l}\text { The cost of regulation most } \\
\text { likely will continue to } \\
\text { increase. }\end{array}$ & $\smile$ & & . \\
\hline & $\begin{array}{l}\text { A continued trend to decen- } \\
\text { tralize decision making may } \\
\text { lnhibit further deployment. }\end{array}$ & $\begin{array}{l}\text { The course of this trend } \\
\text { is unknown. }\end{array}$ & & \\
\hline TPV & $\begin{array}{l}\text { This technology faces few } \\
\text { current regulatory barriers. }\end{array}$ & & & $\cdot$ \\
\hline SPS & $\begin{array}{l}\text { The current regulatory } \\
\text { system may delay SPS } \\
\text { deployment. } \\
\text { The cost of meeting. regu- } \\
\text { lations may constrain } \\
\text { deployment without } \\
\text { suffictent lead times. }\end{array}$ & $\begin{array}{l}\text { International sovereignty } \\
\text { issues are unresolved. } \\
\text { The extent of potential } \\
\text { environmental impacts } \\
\text { is unknown. }\end{array}$ & $\begin{array}{l}\text { Develop an alternative } \\
\text { regulatory configuration } \\
\text { that minimizes known } \\
\text { institutional problems. }\end{array}$ & $\begin{array}{l}\text { SPS has a unique international } \\
\text { issue (radio frequency alloca- } \\
\text { cion, orbital assignment, } \\
\text { and microwave health } \\
\text { standards). }\end{array}$ \\
\hline Fusion & Not addressed. & & & . \\
\hline $\begin{array}{l}\text { Conpara- } \\
\text { tipe } \\
\text { Analysis }\end{array}$ & $\begin{array}{l}\text { The least mature techno- } \\
\text { logies (1.e., SPS, Fusion) } \\
\text { face more regulatory } \\
\text { constraints and possible } \\
\text { cost increases than more } \\
\text { nature technologies, since } \\
\text { a regulatory scenario is } \\
\text { not yet defined. }\end{array}$ & $\begin{array}{l}\text { The SPS has more unsettled } \\
\text { regulatory issues than the } \\
\text { other energy systems. }\end{array}$ & $\begin{array}{l}\text { Assess regulatory effects } \\
\text { on the deployment schedule } \\
\text { of the scenario. }\end{array}$ & . \\
\hline
\end{tabular}


the status, uncertainty, and future direction for each of the six issue areas in the comparative assessment, i.e., cost and performance, health and safety, environmental welfare, resources, economic/societal, and institutional.

Cost and Performance

The initial cost and performance assessment encountered difficulties in making consistent comparisons because of the different maturity levels of the technologies being compared. For example, since the SPS as a concept is in the definition stage, no reliability analyses have been performed. The lack of these data has prevented a consistent comparison since the cost of energy delivered by these technologies depends on both the cost and performance (e.g., reliability) of the energy system.

Preliminary uncertainty analyses were performed on the capital costs of altérnative energy technologies. These initial efforts: were rewarding in the sense that they showed a new perspective on cost comparisons. This new perspective focused on the relative costs of the technologies rather than on a comparison of the absolute costs of each technology. Furthermore, the uncertainties of these relative costs were analyzed. Consideration of cost uncertainties adds a valuable dimension to the analys is by keeping large cost differences in perspective. For example, the outcome of the comparison between the SPS and TPV depends partially on cell cost. As cell costs decrease and efficiency improves, TPV improves in comparison to the SPS because the latter has cost components not included in the cost of TPV (i.e., space transportation and construction).

Cost and performance analys is depends quite heavily nn assumptions about future deployment levels and world economy. Future assessments will provide a series of scenarios that include these parameters.

Healch and safety

Health and safety issues were identified and grouped in quantified and nonquantified categories, and the potential severities of the issues were rated. Many of the key issue areas will remain unresolved in the time frame (June 1980) of the comparative assessment because of the unavailability of basic research data. This initial health and safety assessment did not include all available research information, and the preliminary views about severity and uncertainty for those issues will probably change as more information is analyzed. Future health and safety assessments should incorporate all available research on key unresolved issues and address the problems of documented impacts by the scenario approach.

\section{Environmental Welfare Issues}

A number of issues were described but not quantified in the preliminary assessment. It will be appropriate in subsequent assessments to identify or at least bracket the potential costs for key issues: The availability of supply scenarios and hypothetical siting patterns will aid in defining more specifically the true sizes and ranges of impacts in this issue area. 
Resources

The water resource problem received 1 imited attention in the preliminary assessment because it is primarily a regional and local problem. Only through the evaluation of specific deployment scenarios and hypothetical sites can the water resource problem be addressed. For water resource analyses, regional and local consumption for uses other than energy technology must be defined by the scenarios.

The energy assessment concluded that net energy balance is not a key resource issue. Terrestrial photovoltaics and SPS technologies had much higher payback periods than other technologies considered, but improvements in cell energy production should bring these down to acceptable levels. It is not expected that net energy will receive attention in future assessments.

Land is a serious resource consideration for the SPS and terrestrial photovoltaic systems. Although LWRs and coal technologies use approximately the same amount of land on a total fuel cycle basis, the large amount of contiguous land required for the SPS and TPV creates a different type of problem. Future land assessments should utilize scenarios and hypothetical sites to determine the amount and type of land that will be consumed by deployment of these technologies. Siting studies performed in the SPS societal assessment and alternative technology siting performed by DOE could serve as the basis for these scenarios. This approach provides a much better perspective on the land resource issue.

\section{Economic/Societal Issues}

Macroeconomic effects are measured by changes in GNP flow, unemployment rates, and inflation rates. Indirect system dollar costs are all infrastructure, residual pollution, resource, and monetary welfare costs that could affect the economy. Certain macroeconomic effects are considered at the regional. (Census Bureau regions) and income class levels as well as at. the national level.

Overal1, a socioeconomic assessment concerns the effects of various power options on the financial and social lives of the populations living in. the vicinity of energy system sites. Financial effects include public infrastructure costs and effects on local employment, wages, prices, and property values: Social stresses can result from rapid growth, changes in local political structure, and cultural changes. Effects such as local inflation, crime rates, community structural changes, and labor migration have occurred in the past.

The SPS could have a significant impact on the national economy, as could other advanced technologies, because of its large capital demand and undetermined investment requirements in industrial infrastructure. segional macroeconomic issues vary between technologies. Coal technology would basically affect the western states; terrestrial photovoltaics would probably be sited mostly in the Southwest; but nuclear fission and fusion plants would not have a geographical bias. Future assessments can appropriately utilize. the future supply/demand scenarios and world economy assumptions and provide a 
better perspective on the relative macroeconomic and socioeconomic impacts of the SPS and alternatives.

\section{Institutional Issues}

The preliminary institutional assessment identified the costs and motivations for regulatory procedures. On the basis of the historical trends of regulatory institutions, it is expected that the SPS can expect both deployment delays and increased costs due to federal, state, and local regulatory agencies. The inclusion of a regulatory scenario in the development process could minimize this problem. In addition, international institutions may have major impact on the deployment of the SPS. Energy supply scenarios that are considered in the next step of the preliminary assessment $r a n$ be examined to determine whether or not they are realistic from a regulatory perspective. 


\section{REFERENCES}

1. Wolsko, T., et al., A Methodology for the Comparative Assessment of the Satellite Power System and Alternative Technologies, U.S. Department of Energy Report DOE/ER-0051 (Jan. 1980).

2. U.S: Department of Energy and NASA, SPS CDEP Reference System Report, DOE/ER-0023 (Oct. 1978).

3. TRW, Energy Systems Planning Division, Characterizations of Alternative Electric Generation Technologies for the SPS Comparative Assessment: Vol6. 1 and 2, Central-Station Technologies, Argonne National Laboratory Report ANL/EES-TM-121 (Aug. 1979).

4. United Engineers and Constructors, Satellite Power System and Alternative Technology Characterization, UE\&C-ANL-790831 (Aug. 1979).

5. Boeing Aerospace Corporation, Solar Power Satellite System Definition Study, Volume I, Phase 1, Final Report, D180-25037-1 (Feb. 1979).

6. Rockwell International Corporation, Satellite Power Systems (SPS) Concept Definition Study, (Exhibit C) Final Performance Review, SSD79-0076 (March 1979).

6a. Boeing Aerospace Corporation, Solar Power Satellite System Definition Study, Executive Summary, D180-25969-1 (June 1980).

6b. Piland, R.0., Reference System Characterization and Cost Overview, DOE/ NASA Program Review (April 1980).

6c. Woodcock, G.R., Solar Power Satellites and the Evolution of Space Technology, presented at the 1980 International Meeting and Technical Display of the American Institute of Aeronautics and Astronautics, Balt imore, Md. (May 1980).

7. Samsa, M., Selection of Alternative Central Station Technologies for the Satelizte Fower System Comparative Assessment, U.S. Department of Energy Report DOE/ER-0052 (April 1980).

8. Kotin, A.D., Satellite Power System (SPS) Resource Requirements (Critical Materials, Energy, and Land), HCP/R-4024-02, U.S. Department of Energy (Oct. 1978).

9. Marsh, W.D., Requirement Assessments of Photovoltaic Power Plants in Electric Utility Systems, Vols. 1-3, General Electric Company, EPRI Report ER-685 (June 1978).

10. Brown, D.H., Conceptual Design and Implementation Assessment of a Utility Steam Plant with Conventional Furnace and Wet Lime Stack Gas Scrubbers, General Electric Company for EPA, TVA, NASA, NSF and ERDA, NAS3-19406 (1976). 
11. Shah, R.P., Energy Conversion Alternatives Study (ECAS), General Electric for NASA Lewis Research Center, NASA-CR 134949 (1978).

12. United Engineers and Constructors, Alternative Power Systems (1978).

13. U.S. Nuclear Regulatory Commission, Final Envirormental Statement ReZated to Constmuction of Cherokee Nuclear Station Units 1, 2, 3, Docket Nos. STN 50-491, STN 50-492 and STN 50-493, NUREG-75/089 (October 1975).

14. U.S. Atomic Energy Commission, Final Environmental Statement Related to Construction of Grand Gulf Nuclear Station Units 1 and 2, Docket Nos. 50-416, 50-417 (August 1973).

15. U.S. Atomic Energy Commission, Proposed Final Environmentai Statement, Liquid Metal Fast Breeder Reactor Program, Vol. IV, WASH-1535, (Dec. 1974).

16. U.S. Energy Research and Development Administration, Final Environmental Statement Related to Construction and Operation of Clinch River Breeder Reactor Plant, Docket No. 50-537 (Feb. 1977).

17. University of Wisconsin Fusion Feasibility Study Group, NUWMAK II, $A$ Conceptual Tokamak Power Reactor Design, University of Wisconsin, Madison, Wisc. (1975).

18. United Engineers and Constructors, Final Report and Initial Update of the Energy Economic Data Base (EEDB) Program, prepared for the U.S. Department of Energy, Co0-4954-1 (December 1979).

19. Personal Communication, letter: Robert Q, Piland (NASA) to Thomas D. Wolsko (ANL), Oct. 26, 1979, Ref. EW4-79-197.

20. Boeing Aerospace Corporation, Solar Power Satellite Systems Definition Study, Part III (March 7, 1978).

21. Technology Assessment Guide, EPRI Report PS-866-SR, Special Report (June 1978).

22. Meyers, M.L., and L.C. Fuller, A Procedure for Estimating Nonfuel Operation and Maintenance Costs for Large Steam-Electric Power Plants, Oak Ridge National Laboratory, TM-6467 (Jan. 1979).

23. Handy-Whitman Index of Public Utility Constmetion Costs, Whitman, Requardt and Associates, Publishers, Baltimore, Md. (1978).

24. Personal Communications, Whitman; Requardt and Associates (1979).

25. Personal Communication, E. Ziegler, United Engineers and Constructors, Philadelphia, Penn. (1979).

26. Kraft, C.C., The Solar Power Satellite Concept-- The Past Decade and the Next Decade, Paper \#19-0534, AIAA 15th Annual Meeting and Technical Display, Washington, D.C. (Feb. 1979). 
27. National Aeronautics and Space Administration; Initial Technical, Envirormental and Economic Evaluation of Space Solar Power Concepts, NASA Lyndon B. Johnson Space Center, Houston, Texas (Aug. 1974).

28. National Aeronautics and Space Administration, Solar Power Satellite Concept Evaluation Activities Report July 1976 to June 1977, NASA Lyndon B. Johnson Space Center, Houston, Texas (July 1977).

29. Hazelrigg, G.A., Assessment of Economic Factors Affecting the Satellite Power System, Vol. I, System Cost Factors, Report 非8-147-1 prepared for NASA, ECON, Inc., Princeton, N.J., P. 57 (Dec. 1978).

30. Glaser, P., Economic Envirormental Costs of Satellite Solar Power, Mechanical Engineering (Jan. 1978).

31. U.S. Department of Interior, Energy Perspectives II, Washington, D.C., p. 89 (June 1976).

32. U.S. Department of Energy, Energy Information Administration Anmal Report to Congress, Vol: II, 1977, DOE/EIA-0036/2 (April 1978).

33. EEI Statistical Year Book, 1978, Edison Electric Institute, New York.

34. EPRI, Fuel and Energy Price Forecasts: Quantities and Long Term Marginal Prices, EPRI Report EA-433, Palo Alto, Calif. (Sept. 1977). Uses results from SRI National Energy Model.

35. EPRI, Assessment of Fuels for Power Generation by Electric Utility Fuel: Cells, EPRI Report EM-695, prepared by ADL, Cambridge, Mass.

36. Price, B.E., et al:, A Survey of Nuclear Fuel Cycle Economic8: 1970-1985, ORNL/TM-5703, Oak Ridge National Laboratory (March 1977).

37. Crowley, J.H., Power Plant Cost Estimates Put to the Test, United Engineers and Constructors (1978), Reprinted in Nuclear Engineering. International (July 1979).

38. NASA Historical Cost Panel, Report to the NASA space l'ost b'valuation Program, Norman Rafel (chairman), NASA (March 20, 1973).

39. Comptroller General of the United States, Need for Improved Reporting and Cost Estimating On Major Unmanned Satellite Projects, U.S. General Accounting office, PSAD-75-190 (July 25, 1975).

40. Personal Communication, J. Long (Planning Research Corporation) to S. Ankerbrandt, regarding Manned Lunar Landing Cost Estimate (Apollo Program) (Jan. 3, 1980).

41. Seamans, Robert C., Jr., and Frederick I. Ordway, The Apollo Tradition: An Object Lesson for the Management of Large-scale Technological Endeavors, Interdisciplinary Science Reviews, Vol. 2, No. 4, 1977 (Cited in Ref. 42). 
42. NASA Report to Vice President Johnson dated April 22, 1961 (Cited in Ref. 42).

43. Memorandum from the Office of the Vice President to the President, Evaluation of Space Program, dated April 28, 1961 (Cited in Ref. 42).

44. 1962 NASA Authorization, Hearings Before the Committee on Science and Astronautics, U.S. House of Representatives Eighty-seventh Congress, First Session on H.R. 6874, July 11,12 and 13, 1961 (Cited in Ref. 42).

45. NASA letter to Senator Clinton P. Anderson dated November 21, 1969 (Cited in Ref. 42).

46. Merrow, E.W., S.W. Chape1, and C. Worthing, A Review of Cost Estimation in New Technologies: Implications for Energy Process Plante, prepared for the U.S. Department of Energy, R-2481-DOE, Rand Corporation, Santa Monica, Calif. (July 1979).

47. Ehrenreich, H., and J. Martin, Solar Photovoltaic Energy, Physics Today (Sept. 1979).

48. Habegger, L.J., J.R. Gasper, and C.D. Brown, Health and Safety: Preliminary Comparative Assessment of the SPS and Other Energy Alternatives, U.S. Department of Energy Report DOE/ER-0053 (April 1980).

49. Federal Power Commission, FPC News, 9(43):23 and 27 (Oct. 22, 1976).

50. Hutt, P., Unresolved Issues in the Conflict between Individual Freedom and Goverrment Control of Food Safety, Frontoxicol. Environ. Safety 2:447-469 (1978). The estimates of $\mathrm{risk}$ in this reference are derived from Wilson, Direct Testimony before the Occupational Safety and Health Administration, OSHA Docket No. H-090 (Feb. 1.978).

31. Work Injury and ILlness Rates, National Safety Council (1978).

52. Occupational Injuries and IZlnesses in the United States by Industry, 1975, Bureau of Statistics, U.S. Department of Labor, Bullet in 1981, U.S. Government Printing Office, Washington, D.C. (1978).

53. Poon, T.Y., et al., Preliminary Examination of Satellite Pmuer Systam occupational Health Impacts, Jet Propulsion Laboratory Report 900-820 Rev. A, Pasadena, Calif. (1979).

54. Preliminary Envirormental Assessment for the Satellite Power System (SPS), Vol. 2: Detailed Assessment, DOE/ER-0021/2, U.S. Department of Energy (Oct. 1978).

55. Gandel, M.G., et al., Assessment of Large Scale Photovoltaic Materials Production, Lockheed Missile and Space Co. EPA-600/7-77-087 (Aug. 1977).

56. Comer, C.L., and L.A. Sagan, Health Effects of Energy Production and Conversion, Ann. Rev. Energy 1:581-599 (1976). 
57. Proc. 3rd Annual Illinois Energy Conference, University of Illinois (Sept. 1975).

58. Comparative Risk-Cost-Benefit study of Alternative Sources of Electrical Energy, Report WASH-1224, Atomic Energy Commission, Washington, D.C. (1974).

59. The Effects on Populations of Exposure to Low Levels of Ionizing Radiation, Report of the Advisory Committee on Biological Effects of Ionizing Radiation, Division of Medical Sciences, National Academy of Sciences, National Research Council (1972).

60. U.S. Energy Research and Development Administration, Conf. on Occupational Health Experience with Uranium, ERDA 93 (April 1975).

61. Cohen, B.L., Impact of Nuclear Industry on Human Health and Safety, Am. Scientist 64:550-559 (Sept: 1976).

62. Cohen, B.t., A Catalog of Risks, Health Phys. 36:707-722 (1979).

63. AMA Council on Scientific Affairs, Health Evaluation of Energy Generating Sources: Council Report, JAMA 240(20):2193-2195 (1978).

64. Study Group on Light Water Reactor Safety, Amer. Phys. Soc. Rev. Mod. Phys. 47(Suppl 1) (1975).

65. Rhoads, R.E., and J.F. Johnson, Risks in Transporting Materials for Various Energy Industries, Nuclear Safety 19(2):135-146 (March 1978).

66. Cralley; L.V., and J.P. Jewe11, Levels of Toxicity to Animals Provide Sound Basis for Fluoride Standards, Envir. Sci. \& Tech. 3(8):721-730 (1969).

67. Morris, S.C., and K.M. Novak, Databook for the Quantification of Health. Effects from Coal Energy Systems, Brookhaven National Laboratory Report 23606 (Dec. 1977).

68. Lundy, R.T., and D: Grahn, Predictions of the Effects of Enengy Production on Human Health, Proc. Am. Statistical Assn. Annual Mig., Chicago, I11. (1977).

69. Accident Bulletin.No. 141, Federal Railroad Administration, U.S. Department of Transportation (1972).

70. Yearbook of Railroad Facts, Association of American Railroads (1973).

71. Lee, D., Coal Workers Pneumoconiosis--State of Knowledge and Research Needs, J. Occupat. Med. 13:183-192 (1971).

72. Synopsis of the Work Proceedings, Spindletop International Conference on Coal Workers, Arch. Environ. Health 21:221 (1970). 
73. Enviro. Control, Inc., Recommended Health and Safety Guidelines for Coal Gasification Pilot Plants, Environmental Protection Agency Report EPA-600/7-78-007 (Jan. 1978).

74. Carcinogens Relating to Coal Conversion Processes, TRW Energy Systems Report FE-2213-1 (June 1976).

75. Harper, W.C., Experimental Carcinogenic Studies of Hydrogenerated Coal Oils, Fischer-Tropasch Oils, J. T.ndust. Med. Surg., Pp. 459-462

(Oct. 1956).

76. Inhaber, H., Risk of Energy Production, Atomic Energy Control Board, Ot tawa, Canada (1977).

77. Caputo, R., An Initial Comparative Assessment of Orbital and Terrestrial Central Power Systems, Jet Propulsion Laboratory, Report 900-7800. Paoadena, Oalif. (1977).

78. Dingee, D.A., Fusion Power: A Special Report, Chemical Eng. \& News, 57:32-45 (April 2, 1979).

79. Kulcenski, G.L, et al., Energy for the Long Run: Fission or Fusion?, Am. Scientist 67:78-89 (1979).

80. Post, R.F., and F.L. Ribe, Fusion Reactors as Future Energy Sources, Science 186(4162):397-407 (1974).

81. Tritium in the Environment, NCRP Monograph 非2 (March 1979).

82. Strand, J.A., and T.M. Peston, Biological Effes los us Activation Hroducts and Other Chemicals Released from Fusion Power Plants, Battelle Northwest Laboratories, BNWL-20-2.3 (1.976).

83. U.S. Atomic Energy Commission, Project Indepondence, Nuclear Energy, Task Force on Nuclear Energy,. Federal Energy Administration (1974).

84. Levine, E.P., et al., Comparative Assessment of Envirormental Welfare Iscues Associated with the Satellite Power System and Alternative Tectirulugies, U.S. Department of Energy Report DOE/ER-0055 (April 1980)..

85. Enviromental Data for Energy Terhnnl.ngy Polioy Analyois, Vul. 1., prepared by Mitre Corp. for U,S. Department nf Energy, DOE Rcport Nu. HCP/EV-6119/i (Jan. 1979).

86. Dvorak, A.J., et al.; The Envirormental Effects of Using Coal for Generating Electricity, U.S. Nuclear Regulatory Commission Report No. NUREG-0252 (June 1977).

87. Energy and Climate, National Academy of Sciences, National Research Council (May 1977). 
88. Energy Alternatives: A Comparative Analysis, Science and Public Policy Program, Univ. of Oklahoma, Norman, Okla., prepared for the Council on Environmental Quality, Stock No. 041-011-00025-4, U.S. Government Printing Office, Washington, D.C. (May 1975).

89. Anmal Environmental Analysis Report, MITRE Corp. (1977).

90. Szabo, M., Environental'Assessment of Coal Transportation, U.S. Environmental Protection Agency Report No. EPA-600/7-78-081 (May 1978).

91. McBride, J., Radiological Impact of Airborne Effluents of Coal and Nuclear Plants, Science, 202(4372):1045-1050 (Dec. 8, 1978).

92. Envirormental Data for Energy Technology Policy Analysis, Vol. 1, prepared by MITRE Corp. for U.S. Deptartment of Energy, DOE Report HCP/EV-6119/1 (Jan. 1979).

93. Envirormental Survey of the Uranium Fuel Cycle, U.S. Atomic Energy Commission Report WASH-1248 (Apri1 1974).

94. Principal Parameters Used in Source Term Calculations, U.S. AEC Directorace of Licensing.

95. Cheremisinoff, P.N., and A.C. Morresi, Envirormental Assessment and Impact Statement Handbook, Ann Arbor Science Press (1977).

96. Bailly Generating Station Nuclear 1. Environmental Report, Northern Indiana Public Service Company (Jan. 1972).

97. Envirorment. Resources, Pollution, and Society, W.W. Murdock, ed., Sinauer Associates Inc., Stamford, Conn. (1975).

98. Gandel, M., et al., Assessment of Large Scale Photovoltaic Materials Production, U.S. Environmental Protection Agency Report EPA-600/7-77-087 (Aug. 1977).

99. Livingston, F.R., Satellite Power System Envirormental Impacts, Preliminary Assessment, Jet Propulsion Laboratory Report 900-822, Rev. A (May 1978).

100. Envirormental Impact Statement: Space Shuttle Program, National Aeronautics and Space Administration, Washington, D.C. (April 1978).

101. Mendillo, M., G.S. Hawkins, and J.A. Klobuchar, A Large-Scale Hole in the Ionosphere Caused by the Launch of Skylab, Science, 187:343 (1975).

102. Kellermeyer, D.A., Climate and Energy: A Comparative Assessment of the Satelizte Power System and Alternative Energy Technologies, U.S. Department of Energy Report DOE/ER-0050 (Jan. 1980).

103. Mitche11, J.M., A Reassessment of Atmospheric Pollution as a Cause of Long-term Changes of Global Temperature, In: The Changing Global Environment, S.F. Singer, ed., D. Reide1, Publisher (1975). 
104. Wang, W.C., et al., Greenhouse Effects Due to Man-Made Perturbations of Trace Gases, Science, 194:685-690 (1976).

105. Kramer, M.L., et al., Cooling Towers and the Environment, J. Air Poll. Contr. Asso., 25:582-584 (1976).

106. Ramsdell, J.V., et al., Postulated Weather Modification Effects of Large Energy Releases, Battelle Pacific Northwest Laboratories, Richland, Wash., BNWLZ-2162 (1977).

107. Lee, J.L., D.M. Rote, and H.D. Orville, Workshop on Meteorological Effects of Satellite Power System Recterna Operation, August 23-25, 1978, Chicago, I11., Bulletin of the American Meteorological Society, $60(11)$ (Nov. 1979).

108. Newsom, D.E., and T.D. Wolsko, Preliminary Comparative Assessment of Land Use for the Sateilite Power System and AZternative Electric Energy. Technologies, U.S. Department of Energy Report DOE/ER-0054 (April 1980).

109. Final Envirormental Statement by the U.S. Nuclear Regulatory Commission for Black Fox Station, Units 1 and 2, proposed by Public Service Company of OkZahoma, NUREG-01\% (Feb. 1977).

110. Energy Conversion Alternatives Study (ECAS), General Electric Phase II Final Report, Volume II, Advanced Energy Conversion Systems, Conceptual Designs: Part 3, Open Cycle Gas Turbines and Open Cycle MHD, NASA-CR 134949, (G.E. Report No. SRD-76-064-2), General Electric Co., Schenectady, N.Y. (Dec. 1976).

111. Systems Descriptions and Engineering Costs for Solar-Related Technologies, MTR-7485, The MITRE Corp/METREK Div. (June 1977).

112. Solar Program Assessment: Environmental Factors - Photovol.tai.es., ERDA 77- 47/3, Energy Research and Development Administration, Washington, D.C. (Mar. 1977).

113. Schwenk, F.C., Briefing Material for the Satellite Power System (SPS) Systems Definition Review (June 5, 1979).

114. Council on Environmental Quality, MERES and The Evaluation of Energy AZternatives, Stock no. 041-011-0026-2, U.S. Government Printing office, Waşhington, D.C. (May 1975).

115. Hub, K.A., et al., Social Costs of Alternative Means of Electrical Power Generation, Argonne National Laboratory Report ANL-80-92,93 (March 1973).

116. Blackburn, J.B., Jr., and B.A. Bavinger, Satellite Power System (SPS) Mapping of Exclusion Areas for Rectenna Sites, HCP/R-4024-10, U.S. Department of Energy. 
117. Energy Conversion Alternatives Study (ECAS) General Electric Phase II Final Report: Volume II, Advanced Energy Conversion Systems: Conceptual Designs: Part 4, Summary of Resulț, NASA-CR 134949, (G.E. Report No. SRD-76-064-2), General Electric Co., Schenectady, N.Y. (Dec. 1976).

118. Evaluation of Phase 2 Conceptual Designs and Implementation Assessment Resulting from the Energy Conversion Alternatives Study (ECAS), NASA TM X-73515, NASA/Lewis Research Center (Apr. 1977).

119. Solar Power Satellite Baseline Review, NASA/MSFC and NASA/JSC, Washington, D.C. (June 5, 1979).

120. Brobst, D.A., and W.P. Pratt, eds., United States Mineral Resources, U.S. Geological Survey Professional Paper No. 820, U.S. Government Printing office, Washington, D.C. (1973).

121. Mineral Facts and Problems, Bureau of Mines, U.S. Department of the Interior, Washington, D.C. (1976).

122. Office of Emergency Preparedness, List of Strategic and Critical Materials, Federal Register, Vol. 37, No. 39 (Feb. 26, 1972).

123. Gallagher, J.M., et al., Resource Requirements, Impacts and Potential Constraints Associated with Various Energy Futures, PAE 3794-6, Bechtel Corp., San Francisco, Calif. (Mar. 1977).

124. Watts, R.L., et al., Some Potential Material Supply Constraints in the Deployment of Photovoltaic Solar Electric Systems: (A Preliminary Screening to Identify Critical Materials), Pacific Northwest L Laboratory, Richland, Wash. (Sept. 1978).

125. Cirillo, R.R., et al., Comparative Analysis of Net Energy Balance of Satellite Power Systems and Other Energy Systems, U.S. Department of Energy Report DOE/ER-0056 (Apri1 1980).

126. Herendeen, R.A., and C.W. Bullard III, Energy Costs of Goods and Services, 1963 and 1967, CAC Document No, 140, Center for Advanced Computation, University of Illinois at Urbana-Champaign (Nov. 1974).

127. Livingston, F.R., et al., Satellite Power System Preliminary Resource Assessment, Document No. 900-805, Rev. A, Jet Propulsion Laboratory, Pasadena, Calif. (Aug. 7, 1978).

128. Herendeen, R.A:, T. Kary, and J. Rebitzer, Energy Analysis of the Solar Power Satellite, Science, 205(4405):451-454 (Aug. 3, 1979).

129. Frabetti, A.J., Jr., et al., Application of Net Energy Analysio to Consumer Technologies, Report No. DSI 047, Development Sciences, Inc., East Sandwich, Mass. (Dec. 22, 1976).

130. Bloomquist, C.E., A Survey of Satellite Power Stations, Report No. DSE/2071-1, P1anning Research Corporation (Sept. 1976). 
131. Atomic Industrial Forum, Inc., Review Group on Design and Construction Project Leadtimes, Licensing, Design, and Construction Problems:

Priorities for Solution, 8, Washington, D.C. (Jan. 1978).

132. Breyer, Stephen, Analyzing Regulatory Failure: Mismatches, Less Restrictive Alternatives, and Reform, Harvard Law Review, 92(3):549-609 (Jan. 1979).

133. Battelle Memorial Institute, Pacific Northwest Laboratory, An Analysis of Federal Incentives Used to Stimulate Energy Production, Richland, Wash. (Dec. 1978).

134. National Coal Association, Special Analysis: Federal Funding for Activitieo Conoornod with Coal, Fiooal Yoaro 10,7, 1080, Washington, D.C. (June 18, 1979).

135. Consolidation Coal Company, Cost Impact Analys is of Selected Provisions of the Office of Surface Mining Permanent Regulatory Program, Denver, Colo. (June 1979).

136. Arthur Anderson \& Co., Cost of Goverrment Regulation Study for the Business Foundtable, Washinglun, D.C. (Mar. 1979).

137. United States General Accounting office, Nuclear Costs and Subsidies, Report by the Comptroller General of the United States, Washington, D.C. (June 13, 1979).

138. Price Anderson Act, P.L. 85-256, 71 Stat. 576 (Sept. 2, 1957).

139. Page, Talbot, A Generic View of Toxic Chemicals and Similar Risks; Ecology Law Quarterly, 7(207) (1978).

140. Report of the President's Commission on the Accident at Three Mile Iszand. The Need for Change: The Legacy of T.M.I., Kemeny, J.G., et al., U.S. Government Printing Office, Washington, D.C.

(Oct. 31, 1979).

141. Naisbitt, John, Satellite Power System (SPS): Centralization/ Decentralization, HCP/R-4024-09, DOE/NASA Satellite Power System Concept Development and Evaluation Program (Oct. 1978).

142. ECON, Inc., Political and Legal Implications of Developing and Operating a Satelzite Power System, Report No. 77-195-1 (Aug. 15, 1977).

143. Satellite Power System (SPS) International Agreements, HCP/R-4024-8, U.S. Dept. of Energy (Oct. 1978).

144. Satellite Power System (SPS) International Agreements, HCP/R-4024-12, U.S. Dept. of Energy (Oct. 1978).

145. Kot in, A.D., Satellite Power System (SPS): State and Local Regulations as Applied to Satellite Power System Microwave Receiving Antenna Facilities, HCP/R-4024-05, DOE/NASA Satellite Power System Concept Development and Evaluation Program (Oct. 1978). 


\section{BIBLIOGRAPHY}

\section{SECTION 2}

Hittman Associates, Inc., Environmental Impacts, Efficiency, and Cost of Energy Supply and End Use, Vol. I (Nov. 1974) PB-238 784, and Vol. II (Jan. 1975) PB-239 159, available from NTIS, Springfield, Va.

Energy Policy Project of the Ford Foundation, A Time to Choose: America's Energy Future, Ballinger Publishing Co., Cambridge, Mass. (1974).

Wilson, Carrol1, L., project director, Energy: GLobal Prospects 1985-2000, Report of the Workshop in Alternative Energy Strategies (WAES), McGraw-Hill, New York (1977).

Wilson, Carroll L., project director, Energy Supply-Demand Integrations to the Year 2000, MIT Press, Cambridge, Mass. (1977).

Foe11, W.K., ed., Proceedings of the 1978 Conference on Alternative Energy Futures for Wisconsin, Wisconsin office of State Planning and Energy, Madison, Wisc. (1978).

Meadows, D.H., et al., The Limits to Growth, Potomac Associates, Washington, D.C. $(1972)$.

Lovins, A., Energy Strategy: The Road Not Taken, Foreign Affairs, 55(1):65-96 (1976).

Lovins, A., Soft Energy Paths: Toward a Durable Peace, Ballinger Publishing Co., Cambridge, Mass. (1977).

Energy Modeling Forum, Energy and the Economy, Electric Power Research Institute Report EPRI EA-620, Palo Alto, Calif. (1978).

Manne, A.S., Energy-Economy Interaction: An Overview of the ETA-MACRO Model, Energiespectrum (Nov. 1977).

Buehring, W.A., W.K. Foe11, and R.L. Keeney, Examining Energy/Envirorment Policy Using Decision Analysi6, Energy Systems and Policy, 2(3):341-367. (1978).

Bierman, H., and S. Smidt, The Capital Budgeting Decision, 2nd ed., The Macmillan Co., New York (1966).

Grant, E.L., and W.G. Ireson, Principles of Engineering Economy, 4th ed., Konald Press Co., New York (1960).

Commonwealth Edison Company, Engineering Economics, Commonwealth Edison' Company, Chicago (1975).

Mishan, E.M., Cost-Benefit Analysi6: An Introduction, Praeger, N.Y. (1971). 
Prest, A.R., and R. Turvey, Cost Benefit Analysis: A Survey, The Economic Journal, 15(300):683-735 (1965).

Fischhoff, B., Cost-Benefit Analysis and the Art of Motorcycle Maintenance, Oregon Research Institute, ORI Research Monograph, Vol. 16, No. 1

(Jan. 30, 1976).

Baecher, G.B., et al., Balancing Apples and Oranges: Methodologies for Facility Siting Decisions, Report No. RR-75-33, International Institute for Applied Systems Analysis, Laxenburg, Austria (Sept. 1975).

Dean, B.V., and M.J. Nishry, Scoring and Profitability Models for Evaluating and Selecting Engineering Projects, JORSA; 13(4):550-570 (1965).

Gaurguilo, G.R., et al., Developing Systematic Procedures for Directing Research Programs, IRE 'I'ransactions on Engineering Managment, Volume EM-7, pp. 2-7 (1968).

Fishburn, P.C., Utility Theory, Management Science, 14(5):335-378 (1968).

E.I. DuPont de Nemours and Co., DuPont Guide to Venture Analysis (1971).

Rúdd, Dale F., and Charles C. Watson, Strategy of Process Engineering, John Wiley and Sons, N.Y. (1968).

Brown, Rex V., Andrew S. Kahr, and Cameron Peterson, Decision Analysio for the Manager, Holt, Rinehart and Winston, N.Y. (1974).

Keeney, Ralph L., and Howard Raiffa, Decisions with Multiple Objectives: Preferences and Value Tradeoffs, John Wiley and Sons, N.Y. (1976).

St anford Research Institute, Decision Analys is Group, Readings in Decision Analysis, Palo Alto, Calif.. (1974).

SECTION 4.5

Federal Energy Administration, National E'nergy Ütlook, U.5. Guverumenl Printing Office (Feb. 1967).

Synfuels Interagency Task Force, Recommendations for a Synthetic Fuels Commercialization Program, Vol. II, Appendix D, U.S. Government Printing nffice (Nov. 1975). 
Distribution of ANL/AA-20

Interna1:

T.G. Alston

J.G. Asbury

J.E. Baker

S.W. Ballou

S. Barisas

P. Bauer

M.J. Bernard

$\mathrm{J}$. Buehring

W. Buehring

R.R. Cirillo

E.J. Croke

$\mathrm{J}$. Cummings-Saxton

$\mathrm{J}$. Dzinge 1

J.J. English

A.R. Evans

P.S. Farber
A.J. Foltman

J.R. Gasper

J.L. Gillette

P. Grogan

L. Habegger

D. Hanson

L. Hill

K.A. Hub

C. Huber

A.S. Kennedy

P. Kier

N.L. Kostyk

A.B. Krisciunas

B.D. LaMar

E. Levine

C.D. Livengood
K.S. Macal

T.J. Marciniak

W.W. Marr

W.E. Massey

M.R. Monarch

R.O. Mueller

D.E. Newsom

L. Poch

K.E. Robeck

J.J. Roberts

D.M. Rote

D. Santini

N.F. Sather

$M$. Senew

A.E. Smith

K.W. Suchy
T.G. Surles (10)

R.L. Tobin

M.F. Torpy

J. Tschanz

A.R. Valentino

J.C. VanKuiken

E. Walbridge

W.J. Walsh

D. Wernette

R.G. Whitfield

K.E. Wilzbach

T.D. Wolsko (183)

A.M. Wolsky

F. Wyant

ANL Contract Copy

ANL Libraries

TIS Files (6)

\section{External:}

DOE-TIC, for distribution per UC-58b (447)

Manager, Chicago Operations and Regional Office, DOE

Chief, Office of Patent Counsel, DOE-CORO

President, Argonne Universities Association

Energy and Environmental Systems Division Review Committee:

W.C. Ackermann, U. Illinois

E.E. Angino, U. Kansas

E.N. Castle, Resources for the Future, Inc., Washington, D.C.

R.L. Clodius, National Assn. of State Universities and Land Grant Colleges, Washington, D.C.

B.A. Egan, Environmental Research and Technology, Inc.

W.W. Hogan, Harvard U.

W.N. Poundstone, Consolidation Coal Company

L.H. Roddis, Jr., Charleston, S.C.

J.J. Stuke1, U. Illinois

J.J. Wortman, North Carolina State U.

S. Ankerbrandt, PRC Systems Sciences Co., McLean, Va.

R.A. Ayres, Carnegie-Mellon University, Pittsburgh, Pa .

R. Bailey, Ohio State University, Columbus, Ohio

D. Beattie, NASA, Washington, D.C.

C. Bloomquict, PRC Systems Sciences, Lós Angeles

R. Bradley, OECD, Paris

D.R. Branscome, House Subcommittee on Space Science and Application, Washington, D.C.

D. Cahill, Environmental Research, EPA, Research Triangle Park, N. C.

H.D. Calahan, NASA Headquarters, Washington, D.C.

J. Chinnis,' Decision Science Consortium, Fallo Church, Va.

D.L. Christensen, Johnson Environmental and Energy Center, Huntsville, Ala.

R.C. Clusen, DOE, Washington, D.C. 
Congressional Research Service, Library of Congress

B.A. Cooper, Senate Subcommittee on Energy Regulations

A.J. Covarrubias, International Atomic Energy Agency, Vienna, Austria

C. Covington, Johnson Space Center, Houston

K. Davis, Battelle Pacific Northwest Laboratory, Richland, Wash.

R. Davis, Oak Ridge National Laboratory

$\mathrm{J}$. Dodd, Office of Management and Budget, Washington, D.C.

D. Dreyfus, Senate Committee on Energy and Natural Resources, Washington, D.C.

K. Duncan, Johnson Space Center, Houston, Texas

L. Duncan, Los Alamos Scientific Laboratory, New Mexico

T.V. Feagans, U.S. Environmental Protection Agency

D. L. Feucht, Solar Energy Research. Institute

W.K. Foell, University of Wisconsin, Madison

A. Ford, Los Alamos Scientific Laboratory

G. Franke1, House Subcommittee on Energy Development and Application

E.A. Frieman, U.S. Department of Energy

5. Gage, U.3. Euvi ivimental Protection Agency

J.H. Gibbons, Office of Technology Assessment, U.S. Congress

P. E. Glaser, Arthur D. Little, Inc., Cambridge, Mass.

J. Grey, AIAA, New York

C. Guttman, Marshall Space Flight Center, Huntsville, Ala.

C. W. Hamilton, Battelle Columbus Laboratory

G. Hanley, Rockwe 11 International, Downey, Calif.

M.E. Hanson, University of Wisconsin, Madison

D. Hesse11, Battelle Pacific Northwest Laboratory

L.J. Hoover, Energy Impact Associates, Pittsburgh

Peter House, U.S. Department of Energy

$\mathrm{J}$. Jaksch, Los Alamos Scientific Laboratory

G.E. Jenks, House Subcommittee Space Science and Application

L. Johns, U.S. Congress, Office of Technology Assessment

G. Jordy, U.S. Department of Energy

D.E. Kash, USGS, Reston, Va.

A. Katz, U.S. Department of Energy

J.S. Kane, U.S. Department of Energy

$\mathrm{J}$. Kennedy, Office of Congressman Flippo

R. Konkel, Senate Subcommittee on Science, Technology and Space

F. Koomanoff, U.S. Department of Energy

T. Kurkowski, U.S. Department of Energy

R.E. Levien, International Institute for Applied Syslems Analysis, Austria

R. T.ohrding, Los Alamos Scientific Laboratory

S.V. Manson, NASA Headquarters

D. Monti, U.S. Department of Energy

E.L. Morrison, U.S. Department of Commerce, Boulder

K.L. Ulson, Boeing Aeruspace Company, Searcle

W.B. Olstad, NASA Headquarters

N. Pewitt, U.S. Department of Energy

M.B. Prince, U.S. Department of Energy

D. Parzyck, Oak Ridge National Laboratory

D. Patrick, U.S. Environmental Protection Agency

$\mathrm{J}$. Peerenboom, University of Wisconsin, Madison

R. Phillips, U.S. Department of Energy

$\mathrm{J}$. Richardson, National Academy of Sciences

M. Riches, U.S. Department of Energy

C: Rush, U.S. Department of Commerce, Boulder 
M.E. Samsa, ETA Engineering, Westmont, Ill.

C. Sandah 1, Argonne National Laboratory, Washingt on

A. Sarvis, Senate Committee on Commerce, Science and Transportation

C.F. Schwenk, NASA Headquarters

R. Shull, U.S. Department of Energy

W. Siri, Lawrence Berkeley Laboratory

P. Smith, Executive office of the President

W. Smith, Senate Subcommittee on Energy Research and Development

H. Spillan, House Subcommittee on Energy and Water Development

A. Starr, U.S. Department of Energy

B. Stein, National Science Foundation

T. Stelson, U.S. Department of Energy

$\mathrm{J}$. Struthers, Office of Management and Budget

W. Vesely, Nuclear Regulatory Commission

A. We inberg, Institute for Energy Analys is

C. Whipple, Electric Power Research Institute

I. White, U.S. Environmental Protection Agency

M.R. White, Lawrence Berkeley Laboratory

T. Williams, U.S. Department of Energy

R. Williamson, U.S. Congress, Office of Technology Assessment

G.R. Woodcock, Boeing Aerospace

R. Wyzga, Electric Power Research Institule

J. Zinn, Los Alamos Scientific Laboratory 